\title{
AS OUVIDORIAS DE POLÍCIA NO BRASIL: CONTROLE E PARTICIPAÇÃO
}

\author{
Bruno Konder Comparato
}

Tese apresentada ao Programa de Pós-Graduação em Ciência Política, da Faculdade de Filosofia, Letras e Ciências Humanas da Universidade de São Paulo, para obtenção do título de Doutor em Ciência Política.

Orientadora: Prof. Dr. Maria Tereza Sadek

São Paulo

2005 
Este trabalho é dedicado a

Ariela, a amada mais amada, sem a qual a vida é nada:

agora sou todo seu

Julinha e companhia

(Rosa, Zezé, Pato, Bia, Neguinha, Pedro) 


\section{AGRADECIMENTOS}

Este trabalho contou com o apoio de várias pessoas e instituições, sem as quais não poderia ser concretizado. Assim, meus agradecimentos vão:

Ao CNPQ, pelo auxílio financeiro, e ao Departamento de Ciência Política, por me acolher em seu programa de pós-graduação.

À minha orientadora, Maria Tereza Sadek, que com muita paciência me mostrou um caminho interessante e frutífero para pesquisar o tema dos direitos humanos.

Aos professores do Departamento de Ciência Política que estiveram de alguma forma relacionados com este trabalho. A todos os funcionários do Departamento, em especial à Raí, pela precisão infalível na lembrança dos prazos.

Aos professores Dra. Maria Victoria de Mesquita Benevides e Dr. Rogério Arantes, pelas importantes contribuições apresentadas no Exame de Qualificação.

A todos os entrevistados, em especial aos Ouvidores da Polícia que deixaram de ouvir um pouco para falar das suas experiências à frente das Ouvidorias.

Aos meus amigos que não precisam ser citados para saber o quanto foram importantes, mesmo que eu tenha me comportado de um modo muito estranho nos últimos tempos.

Aos meus pais, Fábio e Monique, e a todos os familiares pelo apoio incondicional.

À Júlia que, do alto dos seus dois anos, me fez perceber que alguns rabiscos coloridos podem ser muito mais significativos do que páginas e páginas de textos.

E, por fim, à Ariela, que não tinha a mínima idéia de onde estava se metendo quando resolveu compartilhar comigo esta caminhada e, inúmeras vezes, saiu assustadíssima do escritório acreditando que eu estava irremediavelmente perdido. 


\title{
RESUMO
}

O papel da polícia em uma sociedade democrática é auxiliar os cidadãos e fazer com que todos observem as leis. Por isso mesmo, a atividade policial não deve estar acima das leis. Como toda instituição republicana, a polícia deve prestar contas das suas atividades, ainda mais porque utiliza a força, podendo facilmente ultrapassar os limites da violência legítima. A experiência das ouvidorias de polícia mostra que a sua instalação faz diferença. As ouvidorias são instituições que incentivam a participação dos cidadãos. Trata-se de instituições recentes e inovadoras com grande potencial para ajudar a garantir os direitos humanos.

\begin{abstract}
The role of the police in a democratic society is to help citizens and make them obey the law. For this reason, police activities should not be above the law. As with every institution of a republic, the police are expected to be accountable for their actions, even more so because they use force and may easily exceed the limits of justifiable violence. The experience of civilian oversight of the police shows that its existence makes a difference. Such oversight comes in the form of institutions that invite the involvement of citizens. These institutions are recent and innovative with great potential for helping and guaranteeing human rights.
\end{abstract}

\section{PALAVRAS-CHAVE}

Ouvidoria, Polícia, Controle externo, Participação, Direitos Humanos KEYWORDS

Civilian Oversight, Police, External Control, Participation, Human Rights 
"Estamos no ano de 1979. A bravura da mulher brasileira é encarnada por Marli Pereira, que denuncia o assassinato do irmão, um biscateiro de dezoito anos, pela polícia. Enfrenta todas as ameaças exigindo a punição dos quatro culpados. Que ela identifica, aponta, e declara: 'Sou preta, pobre, mas não me considero pior do que ninguém. Tenho pavor de barata, de polícia não.’”

Darcy Ribeiro, Aos trancos e barrancos

"Presidente, o problema de uma lei assim não é o senhor, nem os que com o senhor governam o País. O problema é o guarda da esquina."

Pedro Aleixo, vice-presidente de Costa e Silva, ao comentar o AI-5 em dezembro de 1968, citado por Sebastião Nery na Tribuna da Imprensa, junho de 2005

"Tancredo Neves tinha acabado de ser eleito governador de Minas Gerais. Um amigo o cumprimentava, pois ele tinha sido muito bem votado: 'Parabéns, agora o senhor tem legalidade e legitimidade para exercer esse cargo.' Tancredo virou-se e disse: 'Eu tenho é que ter muito cuidado, pois o cabo que tem a arma, e que está lá no interior, bem longe, pode ter mais poder do que eu."”

Jônathas Silva, secretário de Segurança Pública e Justiça de Goiás, em entrevista ao Diário da Manhã, de Goiânia, 20/10/2004

"Il faut faire peur à ceux qui gouvernent. Il ne faut jamais faire peur au peuple.”

Saint-Just, Fragment sur les Institutions Républicaines

"C'est une expérience éternelle que tout homme qui a du pouvoir est porté a en abuser."

Montesquieu. De L'Esprit des Lois.

"Quis custodiet ipsos custodes?" (Quem guarda os guardiões?)

Decimus Junius Juvenalis, século I AD 


\section{Sumário}

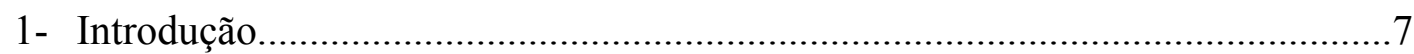

2- As ouvidorias de polícia como um mecanismo para assegurar os Direitos

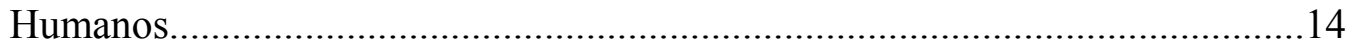

2.1 A entrada do tema dos direitos humanos na agenda pública nacional............14

2.2 A importância da criação de mecanismos institucionais para assegurar os

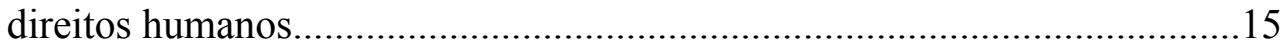

2.3 Importância do controle e da accountability.................................................16

2.4 Por que controlar a polícia.........................................................................17

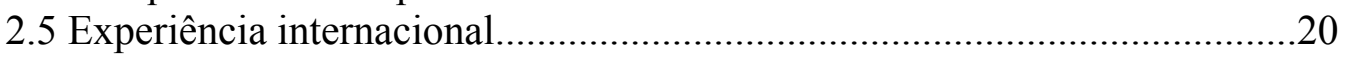

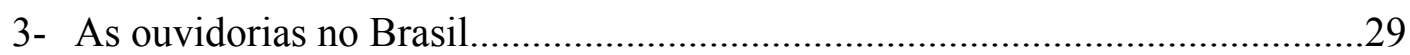

3.1 Como a instituição das ouvidorias entrou na agenda pública nacional...........29

3.2 Papel do Ministério Público no controle da polícia........................................54

4- Ouvidorias de Polícia em atividade no Brasil.......................................................72

4.1 Descrição das Ouvidorias existentes...........................................................72

4.2 Ouvidorias no Brasil............................................................................90

4.3 Comparação entre estados com ouvidoria e estados sem ouvidoria..............106

4.4 Avaliação das ouvidorias de polícia...........................................................116

4.5 Relação entre o governo estadual e a ouvidoria da polícia...........................161

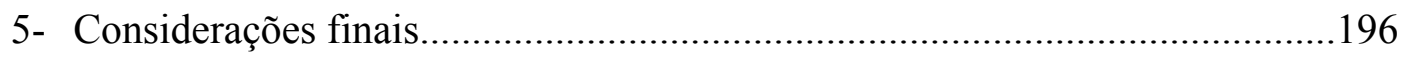

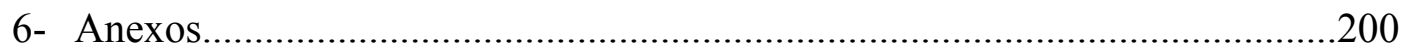

6.1 Minuta de Projeto de Lei para a criação de ouvidorias da polícia nos estados, elaborada Fórum Nacional de Ouvidores da Polícia no seu $\mathrm{IV}^{\mathrm{o}}$ encontro, realizado nos dias $1^{\circ}$ e 2 de outubro de 2003.................................................

6.2 Roteiro para a recepção de denúncias de desvio policial na Ouvidoria da

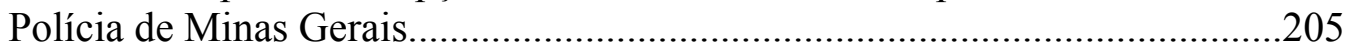

6.3 Evolução dos critérios de avaliação das irregularidades na atividade policial na Ouvidoria da Polícia de São Paulo..............................................................209

6.4 Pesquisa sobre a disponibilidade da informação do telefone da Ouvidoria da Polícia de São Paulo junto às delegacias de polícia da grande São Paulo.........213 6.5 Pesquisa sobre a disponibilidade da informação do telefone da Ouvidoria da Polícia de São Paulo junto aos batalhões da polícia militar da grande São

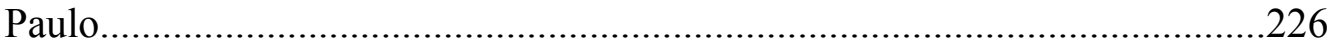

6.6 Exemplares $n^{\circ} 3$ e no 4 e edição extra E2 do jornal eletrônico Otite Crônica, idealizado por Fermino Fecchio quando esteve à frente da Ouvidoria da Polícia do Estado de São Paulo.

7- Bibliografia. 249 


\section{1- Introdução}

No dia 16 de junho de 2004, seis homens armados trocaram tiros com um policial militar no jardim da residência do arcebispo emérito do Rio de Janeiro, cardeal dom Eugenio Sales. O cardeal estava em casa e comentou o episódio: "Como faço parte da comunidade carioca que passa por esses transtornos, não me assustei. Confiemos na bondade divina". ${ }^{1}$ Moral da história: quando o assunto é a violência nas grandes cidades brasileiras, não podemos nem nos queixar ao bispo.

Se o Brasil fosse um país civilizado, ouvimos freqüentemente, bastaria chamar a polícia. Pensando melhor, nem precisaríamos nos incomodar, pois a certeza da sanção do estado afastaria muita gente do mau caminho. Quando, no entanto, resolvemos desafiar o senso comum, de acordo com o qual não vai adiantar em nada prestar queixa à polícia, pois ela é ineficiente e corrupta, e procuramos uma delegacia, não é difícil topar com um delegado que afirma que se não tivesse que se explicar para o "pessoal dos direitos humanos" o seu trabalho daria muito mais resultados.

Dessas situações podemos tirar duas conclusões. Em primeiro lugar, há um reconhecimento bastante difundido na sociedade brasileira de acordo com o qual as instituições estatais ainda deixam muito a desejar no que diz respeito à manutenção da ordem e ao combate contra o crime. Em segundo lugar, há um grupo de pessoas com grande atuação na sociedade civil que discute abertamente as ações e os abusos das instituições policiais e as relaciona com o tema da democracia: os militantes que lutam pela promoção dos direitos humanos. Em relação a este grupo, há controvérsias se a sua presença ajuda ou atrapalha o trabalho da polícia. Não há como negar, contudo, que se trata de um ator presente no debate público brasileiro.

\footnotetext{
${ }^{1}$ Conforme noticiado pelo jornal $O$ Globo, de 17 de junho de 2004 .
} 
O que nos interessa neste trabalho é verificar qual é a relação que podemos estabelecer entre os temas da democracia e dos direitos humanos. Mais especificamente, pretendemos considerar o problema a partir do ponto de vista das políticas públicas de controle e fiscalização da gestão pública com participação popular. O objetivo principal é investigar as possibilidades de efetiva vigência da democracia e dos valores republicanos no Brasil, a partir de políticas públicas que envolvam a participação da sociedade civil. Partimos do pressuposto de que há uma associação essencial entre direitos humanos e democracia, esta entendida como o regime político da soberania popular e do respeito integral aos direitos humanos, o que inclui reconhecimento, proteção e promoção. [Benevides, 2004] Foi escolhido como objeto de pesquisa, dentre vários outros pertinentes à temática da democracia participativa e dos direitos humanos, o estudo das ouvidorias criadas em estados e municípios, como resultado de uma nova concepção (embora polêmica e não consensual) na sociedade e nos governos, sobre a necessidade de um controle público sobre as políticas governamentais e as instituições. Ao refinar nosso objeto de estudo, optamos por limitar-nos ao caso específico das políticas de segurança pública. Há dois motivos que nos empurram fortemente para este lado, um de ordem teórica, outro de ordem prática. Do ponto de vista teórico e de maneira bem sucinta, a polícia é a instituição que garante a materialização e a supervisão do contrato social tal qual resumido pela definição de Hobbes para o Leviatã: "Uma pessoa de cujos atos uma grande multidão, mediante pactos recíprocos uns com os outros, foi instituída por cada um como autora, de modo a ela poder usar a força e os recursos de todos, de maneira que considerar conveniente, para assegurar a paz e a defesa comum”. Num Estado de Direito é preciso enquadrar e limitar o poder do Estado pelo direito, para que todos possam agir "conforme a lei”. A autoridade pública também deve agir em consonância com o Direito. A polícia é a instituição que garante 
que as leis e as decisões judiciais sejam corretamente observadas. A polícia, contudo, pelo simples fato de manejar a força, pode facilmente ultrapassar os limites da violência legítima. Em um regime republicano, todas as instituições devem prestar contas das suas ações. A ênfase deve ser aumentada quando se trata da prestação de serviços que podem usar a força, para que a diferença entre arbítrio e uso legítimo da instituição seja bem delimitada. De acordo com os termos de Weber, estamos falando aqui dos problemas levantados pelos mais diversos autores sobre a questão do monopólio do uso legítimo da força sem o qual não há manutenção de estado possível. Ora, a maneira pela qual esse monopólio da força é exercido é um bom indício a respeito da qualidade da democracia em uma dada sociedade e se os direitos humanos são respeitados ou não. O Programa do Conselho da Europa para a Polícia e os Direitos Humanos ${ }^{2}$, lançado no ano 2000, é claro quanto a esse ponto: "Cada vez que a polícia investiga um delito, executa decisões judiciais ou entra em contato com os cidadãos a quem serve, a sua conduta simboliza a maneira pela qual os direitos humanos são respeitados e protegidos nos países em questão (...) A maneira pela qual a polícia desempenha o seu papel é um indicador infalível do nível da qualidade da sociedade democrática, bem como do seu grau de respeito pela preeminência do direito".

Do ponto de vista prático, o Brasil vem experimentando uma série de novidades neste campo a partir da introdução das ouvidorias nos mais variados níveis da administração pública. Por ocasião do I Encontro Regional de Ouvidorias Públicas, Regiões Sul e Sudeste, realizado em São Paulo, a 27 de agosto de 2004, falou-se em mais de mil ouvidorias públicas atualmente em funcionamento no Brasil. Talvez as mais conhecidas sejam as ouvidorias de polícia, presentes em vários estados da federação, e

\footnotetext{
${ }^{2} \mathrm{O}$ texto do documento pode ser obtido na internet, no endereço www.coe.int/T/F/Droits_de_l'Homme/Police
} 
isto por uma razão que nos interessa muito: as ouvidorias de polícia publicam relatórios trimestrais e anuais bastante detalhados que são divulgados pela imprensa.

Optamos, assim, por adotar as ouvidorias de polícia como nosso objeto de estudo. A nossa aposta, e esperança, é que as ouvidorias de polícia sejam um mecanismo eficaz de controle da atividade policial, de maneira a evitar, constranger ou diminuir bastante, os abusos e excessos cometidos neste campo. A questão que buscamos investigar poderia, portanto, ser traduzida pela seguinte fórmula: "Faz ou não diferença a existência de uma ouvidoria de polícia?”. Para isso comparamos as experiências entre as ouvidorias de polícia já instaladas e, na medida do possível, com estados em que este mecanismo de controle da atividade policial ainda não foi instalado.

O plano do trabalho consiste em três capítulos, que passamos agora a comentar.

No primeiro capítulo pretendemos apresentar a entrada do tema dos direitos humanos na agenda pública nacional, num primeiro momento, e a importância da criação de mecanismos institucionais para assegurar os direitos humanos, num segundo momento. Num terceiro momento, trataremos da importância do controle e da accountability sobre a administração pública. Em seguida, mostraremos porque é importante controlar a polícia e, por fim, tentaremos retratar um pouco da experiência internacional no assunto.

O segundo capítulo consiste numa exposição dos mecanismos de controle externo da polícia no Brasil, que será dividida em duas partes: as ouvidorias e o Ministério Público.

A primeira parte tem por objetivo explicar de que maneira a instituição das ouvidorias entrou na agenda pública nacional. Trata-se de um fenômeno recente, pois é posterior à redemocratização do país embora já tenha havido tentativas de implantar um 
ombudsman no modelo escandinavo desde a independência. O resultado, contudo, não foi a criação de apenas um ombudsman, ouvidor-geral ou representante do povo ligado ao legislativo, como nos países escandinavos, mas uma grande quantidade de ouvidorias para assuntos específicos em todos os níveis da administração, e de preferência ligados ao poder executivo. Neste contexto é que se inscreve a implantação da primeira ouvidoria de polícia do país, criada a partir da iniciativa do então governador do estado de São Paulo, Mário Covas, no primeiro dia do seu mandato.

A segunda parte do capítulo trata do papel do Ministério Público no controle da polícia. Ela se faz necessária porque a Constituição de 1988 menciona (no seu artigo 129, inciso VII) que dentre as funções institucionais do Ministério Público está o controle externo da atividade policial. Esta função é relegada ao segundo plano pelo Ministério Público, que apenas recentemente tem tentado exercer o controle externo da polícia de maneira mais organizada e sistemática.

No terceiro capítulo procuramos responder à indagação: faz ou não diferença uma ouvidoria de polícia?

Começamos por descrever as quatorze ouvidorias de polícia em funcionamento atualmente no país. Foram reunidas informações sobre a legislação que originou cada ouvidoria, o processo de escolha do ouvidor, as condições de funcionamento da ouvidoria, a existência ou não de relatórios de atividades.

Na segunda parte tentamos realizar a difícil tarefa de comparar estados que têm uma ouvidoria de polícia com estados nos quais ainda não há ouvidoria. A dificuldade reside no fato de que nos estados em que não há ouvidoria é difícil conseguir as informações necessárias. Isto por si só já é um primeiro indício de que a implantação de uma ouvidoria tem potencial de provocar impactos. Para a realização do $2^{\circ}$ Relatório 
sobre o Plano Nacional de Direitos Humanos, o Núcleo de Estudos da Violência da USP reuniu uma grande quantidade de informações, coletadas junto a cada um dos 26 estados da federação. Dentre os dados requisitados aos governos estaduais há uma parte importante relativa à violência policial. É importante ressaltar que os dados foram conseguidos com a ajuda de Paulo Sérgio Pinheiro, diretor do Núcleo de Estudos da Violência e então Secretário de Estado dos Direitos Humanos, e que a carta de apresentação enviada junto com o roteiro para o fornecimento dos dados apresentava o relatório como de interesse do governo federal. Parece-nos, portanto, improvável que seja possível conseguir dados mais detalhados. De uma maneira geral podemos dizer que, além do fato já esperado de que nos estados com ouvidoria de polícia os dados são muito mais organizados e volumosos, nos estados em que ainda não há ouvidoria esta função é, bem ou mal, exercida por outros grupos como a OAB local, Conselhos de Defesa da Pessoa Humana, Comissões de direitos humanos das assembléias legislativas, a Comissão Pastoral da Terra, relatórios de observadores internacionais em missão oficial no país, organizações não governamentais de defesa dos direitos humanos e de combate à violência, matérias publicadas na imprensa local.

$\mathrm{Na}$ terceira parte, tentamos fazer uma avaliação dos resultados apresentados pelas ouvidorias de polícia. Procedemos a uma descrição do funcionamento de uma ouvidoria, desde o recebimento da denúncia até o seu encaminhamento aos órgãos corregedores ou ao ministério público, e a posterior elaboração dos relatórios de atividades. Nos detivemos também sobre uma análise das categorias de denúncia em cada ouvidoria, em função da corporação policial a que se referem, polícia civil ou polícia militar. Fizemos algumas considerações a respeito do perfil dos denunciantes e de alguns casos representativos. 
$\mathrm{Na}$ quarta parte, aproveitamos as entrevistas que realizamos com vários ouvidores para expor o relacionamento algumas vezes conflituoso, outras, harmonioso, outras ainda, submisso, que as ouvidorias têm com os governos estaduais. A questão da necessidade de melhorar a divulgação dos telefones das ouvidorias e de tornar o seu trabalho mais conhecido foi levantada. Apresentamos o debate sobre a questão da possibilidade das ouvidorias realizarem investigações próprias e independentes como forma de combater o corporativismo policial. Por fim, mencionamos algumas conquistas significativas das ouvidorias de polícia.

5- Na conclusão, será feito um balanço do que foi exposto anteriormente. 


\section{As ouvidorias de polícia como um mecanismo para assegurar os}

\section{Direitos Humanos}

\subsection{A entrada do tema dos direitos humanos na agenda pública nacional}

Consideramos que os direitos humanos passaram a fazer parte da agenda política a partir do momento em que os temas relativos a eles são discutidos em várias instâncias de governo, ao mesmo tempo que algumas ações são implementadas no sentido de colocá-los em prática. Com efeito, estão em funcionamento atualmente comissões parlamentares relativas aos direitos humanos nos níveis federal, estadual e municipal. Faz-se necessário lembrar, também, o lançamento do Programa Nacional de Direitos Humanos, pelo governo federal, em 1996. No ano seguinte, em abril de 1997, foi criada a Secretaria Nacional de Direitos Humanos, no Ministério da Justiça, para coordenar e monitorar a execução do programa. Uma conseqüência dessa mobilização foi a elaboração, em São Paulo, de um Plano Estadual de Direitos Humanos, em 1998. Em 2002, o Programa Nacional de Direitos Humanos ganhou uma segunda versão, e desde então vários estados e municípios ganharam um programa estadual (ou municipal) de direitos humanos.

Já se foi o tempo em que os direitos humanos constituíam um tema tabu para o governo federal, que inclusive proibia seus representantes oficiais no exterior de mencionar a expressão "direitos humanos" em comunicações formais com representantes estrangeiros. ${ }^{3}$ Os seus defensores eram acusados de ingerência em assuntos internos. A partir da redemocratização do país, e do discurso do presidente José Sarney na Organização das Nações Unidas, em 1985, a abordagem do tema mudou

\footnotetext{
${ }^{3}$ Conforme depoimento do embaixador Rubens Ricupero dado ao autor em setembro de 2001.
} 
significativamente. Naquele discurso, o presidente afirmou que: "Os direitos humanos adquirem uma dimensão fundamental, estreitamente ligada à própria prática da convivência e do pluralismo. (...) Com orgulho e confiança, trago a esta Assembléia a decisão de aderir aos Pactos Internacionais das Nações Unidas sobre Direitos Civis e Políticos, à Convenção contra a Tortura e outros Tratamentos ou Penas Cruéis, Desumanos ou Degradantes, e sobre Direitos Econômicos, Sociais e Culturais. Com essas decisões, o povo brasileiro dá um passo na afirmação democrática do seu Estado e reitera, perante si mesmo e perante toda a Comunidade internacional, o compromisso solene com os princípios da Carta da ONU e com a promoção da dignidade humana”.

Passados vinte anos, contudo, estamos numa situação, no mínimo, incômoda: apesar do país ser signatário de todas as Declarações e Pactos internacionais de Direitos Humanos, continuamos a ser denunciados por constantes violações a esses direitos.

\subsection{A importância da criação de mecanismos institucionais para assegurar os direitos humanos}

Aqui é que entra a importância da criação de mecanismos institucionais para assegurar os direitos humanos, pois a implementação e a aceitação dos tratados internacionais de direitos humanos representam, em última instância, questões nacionais. Essa realidade é freqüentemente esquecida pelos militantes de direitos humanos. Mecanismos internacionais e regionais de garantia dos direitos humanos são simplesmente inacessíveis para grande parte da população. A capacidade que um estado tem de honrar os seus compromissos em matéria de direitos humanos depende da força das suas instituições nacionais e da organização e mobilização de grupos da sociedade civil. 
Instituições nacionais de promoção dos direitos humanos podem ser definidas como entidades independentes que são criadas por iniciativa do governo, do poder legislativo ou de ONGs e organizações da sociedade civil com o objetivo de velar pela proteção dos direitos humanos. A maior virtude dessas instituições reside na capacidade que elas apresentam de reduzir a distância entre os tratados internacionais e o governo brasileiro, de um lado, e entre os mecanismos de defesa dos direitos humanos e a sociedade civil, de outro lado. Um ponto fundamental consiste no fato de que o caráter nacional dessas instituições concretiza os princípios universais e os traduz em medidas práticas para o nível local, que é o que realmente interessa. Fazemos questão de sublinhar aqui a diferença entre retórica e ação mas, de qualquer forma, é significativo que os direitos humanos façam parte do discurso.

\subsection{Importância do controle e da accountability}

De alguns anos para cá tem havido um interesse crescente dos cientistas políticos pelo problema fundamental da necessidade de controlar e impor limites aos governantes. Não que se trate de uma discussão nova, nem de um tema novo. No século XVIII, Montesquieu já tinha apontado para a importância da separação de poderes e para o mecanismo do controle mútuo entre os poderes. Inspirados neste autor, aliás, é que os delegados presentes na Convenção de Filadélfia estabeleceram os mecanismos de checks and balances presentes na Constituição norte-americana e consagrados pela fórmula simplificadora de Madison: "Se os homens fossem anjos, não seria necessário haver governo. Se os homens fossem governados por anjos, dispensar-se-iam os controles internos e externos do governo". Autores como Adam Przeworski, Robert 
Dahl e Guillermo O’Donnell mesmo que pertencentes a escolas diferentes de teoria política, têm-se debruçado sobre o assunto e publicado livros recentes sobre o tema. Em uma dessas obras [Przeworski, Stokes, Manin, 1999] encontra-se uma definição de accountability, termo esse de tradução difícil para o português: "A accountability se concentra na obrigação que todo funcionário público tem para com o público, o soberano em última instância em uma democracia, de explicar e justificar o uso que faz do cargo público e da delegação de poderes conferida ao governo através dos processos constitucionais".

Esses trabalhos argumentam que a accountability pode ser considerada a partir de três pontos de vista distintos: o controle pelo voto, o controle externo e o controle interno. Para cada um deles o controle pode ser preventivo (o que eles chamam de control), ou reativo, quando realizado após os fatos (trata-se então de oversight). Sem entrar em detalhes aqui, o que nos interessa é o controle externo da atividade policial realizado pelas ouvidorias de polícia.

\subsection{Por que controlar a polícia}

No início deste texto já foi exposto, em grandes linhas, por que motivo achamos desejável controlar a polícia. Além disso, há uma extensa literatura sobre o (mau) funcionamento da polícia no Brasil. De uma maneira geral, estes trabalhos abordam os problemas existentes na polícia, atribuem o uso excessivo da força a uma permanência das práticas autoritárias da ditadura, expõem a contradição do sistema judicial brasileiro que atribui um papel importante à polícia, e sugerem o policiamento comunitário como solução para aproximar a polícia dos cidadãos. [Benevides, 1985, Caldeira, 2000, Kahn, 
2002, Kant de Lima, 1995, Mingardi, 1992, Pinheiro, 1984 e 2000, Pinheiro e Braun, 1986, Soares, 2000]

O fato de haver tantos seguranças privados é um indício de que a população não confia na polícia. Uma das razões da existência das ouvidorias de polícia é aumentar o grau de confiança na polícia,

Durante a transição do regime autoritário para a democracia havia a ilusão de que a reconstrução das instituições políticas e a substituição do "entulho autoritário"4 por práticas democráticas seria suficiente para a efetivação do estado de direito anunciado nos preâmbulos constitucionais. O que se verificou, contudo, é que, mesmo depois da elaboração de uma nova Constituição, as instituições legais foram reformadas mas ainda mantém-se práticas anteriores de agentes estatais da polícia e de outras instituições de controle da violência. De acordo com Paulo Sérgio Pinheiro, apesar de todos os avanços na sociedade civil e na governabilidade democrática, os pobres continuam a ser as vítimas preferenciais da violência, da criminalidade e da violação dos direitos humanos. Em contraste, o Estado se mostrou incapaz de erradicar a impunidade por crimes cometidos por seus agentes, na mesma extensão que tenta punir os crimes cometidos por criminosos comuns sem meios ou recursos de poder. [Pinheiro, 2000]

Uma parcela significativa do efetivo policial, que hoje combate crimes comuns, utiliza métodos criados durante o regime autoritário para combater a subversão e os inimigos políticos. Além dos métodos de atuação e das táticas empregadas serem inspirados dos tempos da ditadura, os policiais têm sido protegidos de investigações externas e muitos acreditam que não precisam prestar contas das suas ações perante os tribunais ou outras autoridades civis. [Mendez, 2000]

\footnotetext{
${ }^{4}$ Segundo a expressão cunhada pelo ex-ministro da Justiça Fernando Lyra e consagrada por Ulisses Guimarães durante os trabalhos constituintes de 1986 e 1987.
} 
Segundo Caco Barcelos [Barcelos, 1992], que investigou as mortes violentas envolvendo policiais atribuídas a tiroteios entre 1970, ano da criação da polícia militar, e 1992, os matadores da polícia, muitas vezes, são incentivados pelo comando a matar criminosos. Na sua análise dos inquéritos abertos pela Justiça Militar, relativos aos casos de homicídios cometidos por policiais, ele descobriu várias provas de que os policiais militares são incentivados a matar criminosos durante o patrulhamento da cidade. Alguns documentos revelam, inclusive, que os matadores que mais se destacam na caça aos suspeitos são elogiados e recebem prêmios patrocinados por seus comandantes. Tanto os prêmios, quanto os elogios, são anotados em suas fichas disciplinares e os ajudam a somar pontos para futuras promoções na carreira.

Recentemente, o governo do Rio de Janeiro instituiu a "promoção faroeste" que premia policiais que eliminam bandidos, e a polícia militar é acusada por moradores de favelas da zona norte da cidade de usar veículos blindados para matar inocentes ou suspeitos rendidos. Os veículos são da cor preta e têm o símbolo de uma caveira pintada na porta. ${ }^{5}$

A questão do controle da polícia, contudo, não está presente apenas em situações em que os abusos são notórios. Desde os primórdios da organização das forças policiais nas democracias ocidentais, houve a preocupação com a possibilidade da polícia usurpar as funções do juiz e do júri ao atribuir culpas e punições. Havia a preocupação de que a polícia se tornasse um agente coercitivo do estado. [Parc, 2005] Assim, a legislação introduzida por Sir Robert Peel, que foi o idealizador do policiamento moderno na Inglaterra, separava categoricamente o trabalho da polícia das funções judiciais e restringia a atividade policial à prevenção e detenção do crime. Peel já se preocupava com a necessidade dos agentes policiais prestarem contas à sociedade da qual faziam

\footnotetext{
${ }^{5}$ De acordo com relato na edição do dia 15 de setembro de 2005 da Folha de S.Paulo.
} 
parte. Vejamos, por exemplo, os três últimos dos nove princípios de Peel, que estabeleceram os princípios fundadores do policiamento inglês e, mais tarde, do policiamento americano, ao afirmar que o papel da polícia é:

- manter a todo momento um relacionamento com o público que confirme a tradição histórica de acordo com a qual a polícia faz parte da sociedade e a sociedade faz parte da polícia (...);

- reconhecer a todo momento a necessidade de aderir integralmente às funções executivas da polícia, e evitar usurpar os poderes do judiciário ou vingar particulares ou o estado, ao julgar alguém culpado e aplicar uma punição;

- reconhecer sempre que a eficiência da polícia deve ser medida pela ausência de crimes e desordem, e não a visibilidade da ação policial ao lidar com o crime ou a falta de ordem. [Parc, 2005]

Segundo Bayley, a polícia regulamenta as liberdades essenciais à democracia [Bayley, 1997] e vários testemunhos afirmam que sem a existência de algum tipo de mecanismo de controle externo da polícia, não é possível realizar a democracia. [Lewis, 2000]

\subsection{Experiência internacional}

No plano internacional, há um interesse e uma necessidade cada vez maiores por mecanismos de controle da atividade policial que incluam a participação popular (em inglês estes mecanismos costumam ser chamados de citizen review, civilian oversight, ou termos similares). 
Uma experiência interessante é a da Irlanda do Norte que, em 1998, conseguiu pôr fim a trinta anos de conflito armado nas ruas a partir de uma negociação que incluiu uma reforma completa da força policial e a criação de uma ouvidoria de polícia com amplos poderes, inclusive o de investigar por conta própria as ilegalidades cometidas por policiais.

Algumas dessas experiências ajudaram os primeiros ouvidores da polícia brasileiros a criar regras e uma rotina de trabalho. O primeiro ouvidor da polícia de São Paulo, Benedito Mariano, por exemplo, fez uma viagem ao Canadá ao implantar a primeira ouvidoria da polícia do país.

A criação de ouvidorias de polícia e mecanismos de controle externo da atividade policial representam um fenômeno relativamente recente. Em texto escrito em 1985, resultado de um estudo internacional comparativo sobre instituições nacionais de polícia nos Estados Unidos, Índia, Japão, França, Grã-Bretanha, Noruega e Cingapura, um estudioso da polícia afirmava que comissões de avaliação civis, responsáveis por receber e investigar reclamações sobre má-conduta policial “foram populares por algum tempo nos Estados Unidos na década de 60, mas deixaram de operar completamente". [Bayley, 2001]

Nos Estados Unidos, a indagação sobre quem deve controlar a polícia teve respostas diferentes em função dos problemas de cada época. [Parc, 2005] Logo após a sua criação, em 1844, a polícia de Nova York, New York Police Department (NYPD), era controlada pelos chefes políticos locais. As conseqüências eram a difusão da patronagem e da corrupção. Numa tentativa de corrigir estes problemas, surgiram os primeiros "Boards of Police" e as "Police Commissions". Em Nova York, por exemplo, o prefeito, o chefe da polícia e um juiz designaram os integrantes da primeira Comissão da Polícia da Cidade de Nova York (New York City Police Commission). Até o século 
vinte, somente os prefeitos, às vezes auxiliados por comissões, representavam o principal poder de controle da polícia. O poder mais significativo do prefeito era contratar e despedir o chefe da polícia. Alguns prefeitos não abandonaram a prática de tratar a polícia como seu feudo particular e exigiam que ela levantasse fundos para as suas campanhas políticas além de proteger os seus apadrinhados.

Em conseqüência a uma nova onda de reforma da polícia, no início do século vinte, surgiu um novo modelo para o controle da polícia. O movimento progressista nos EUA no primeiro quartel do século desconfiava muito dos políticos e do processo eleitoral e considerava ambos corruptos. Para os progressistas, o poder sobre a polícia deveria ser colocado nas mãos de "cidadãos de bem”, ou seja, banqueiros, comerciantes estabelecidos, advogados reputados por sua integridade moral, que dedicariam uma parte do seu tempo para, sem nenhuma forma de remuneração, exercer um controle sobre a polícia de forma apartidária, apolítica e independente. Com o objetivo de separar a polícia da política, o poder de contratar e demitir o chefe da polícia foi transferido para o grupo dos “cidadãos de bem" integrantes das comissões policiais. Para os seus idealizadores, essas comissões deveriam funcionar como filtros que isolassem o departamento de polícia do prefeito e da política partidária. Elas não foram criadas para comandar as corporações policiais, mas para estabelecer as diretrizes e a linha de ação do departamento e controlar o chefe da polícia e os seus auxiliares diretos. Este modelo de comissão policial, contudo, nuca funcionou a contento. Os integrantes da comissão eram designados pelo prefeito ou pelo conselho municipal, de modo que os interesses partidários não foram eliminados e os prefeitos continuaram a exercer um papel significativo na escolha do chefe da polícia. Aos cidadãos escolhidos para essas comissões faltava o conhecimento dos segredos da atividade policial, e eles não dispunham do tempo necessário para adquiri-lo. 
A independência do chefe da polícia e do departamento policial frente a essas comissões levou os chefes da polícia a se tornarem um poder autônomo que, na prática, não respondia a ninguém. Essa falta de controle levou ao abuso do poder principalmente com relação ao policiamento de minorias raciais e étnicas. A polícia passou a ser vista como um exército de ocupação política de repressão para defender e servir as classes média e superior brancas contra as minorias negras. Os distúrbios raciais dos anos sessenta nos EUA foram originados, na sua maioria, de episódios em que um cidadão negro foi assassinato por um policial ou de incidentes de uso excessivo da força contra minorias raciais. Vários autores apontam a importância do caso Rodney King, em que um grupo de policiais de Los Angeles foi filmado agredindo um cidadão negro, em 1992, o que gerou uma onda de protestos e depredações ${ }^{6}$, para a grande popularidade das ouvidorias de polícia a partir dos anos noventa. [Walker, 2001] Mais importante que o crescimento do número de ouvidorias, como pode ser verificado no gráfico abaixo, é a experimentação de diferentes métodos de controle externo que o episódio suscitou.

\footnotetext{
${ }^{6} \mathrm{O}$ chefe da polícia local, Darryl Gates, tinha mandato vitalício mas renunciou em virtude da repercussão do caso. [Dias Neto, 2000]
} 


\section{Crescimento das Ouvidorias de Polícia nos EUA}

$(1970-2000)$

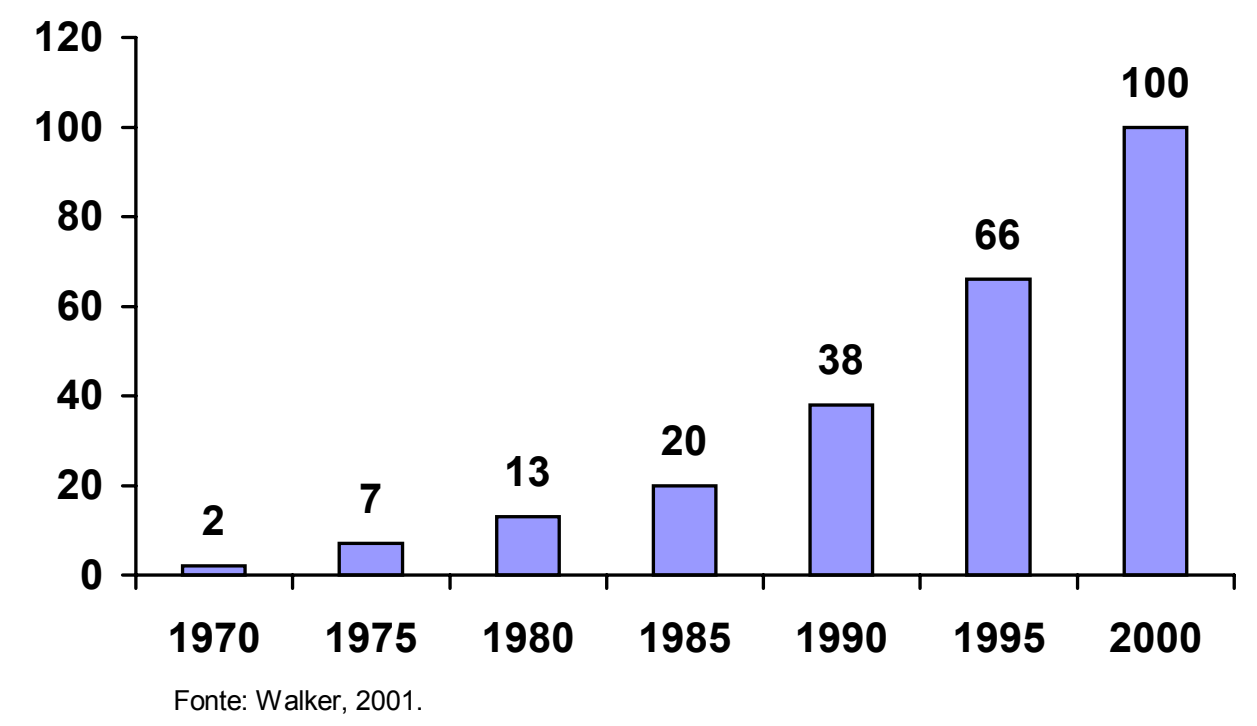

A ouvidoria da polícia na Inglaterra e no País de Gales (Independent Police Complaints Commission), foi instalada em 2002, em seguida aos distúrbios de Brixton, no início da década de 1980, e ao Macpherson Inquiry, em 1993, que se seguiu à morte de Stephen Lawrence, e concluiu pela necessidade de criar um órgão independente para controlar e investigar a polícia. Ela veio substituir a Police Complaints Authority, criada em 1985, com o objetivo de elaborar um Código de Prática Policial e supervisionar as investigações realizadas pelas autoridades policiais. Na Irlanda, a ouvidoria (Garda Siochana Complaints Board) foi instalada em 1986. Na Irlanda do Norte, a ouvidoria (Police Ombudsman for Northern Ireland) foi instalada em 1998. Na África do Sul, a ouvidoria da polícia (Independent Complaints Directorate) foi instalada em 1997, na esteira do movimento de democratização do país, após o final do regime de apartheid, no início dos anos 1990, e a promulgação de uma nova Constituição, que coincidiu com o final do governo de união nacional, em 1996. Na Colômbia, após uma menina de nove 
anos ter sido estuprada e morta em uma delegacia de Bogotá em 1993, foi criado o Comisionado Nacional para la Policía (CNP), que teve quatro ouvidores até ser extinto em 1997, em razão da falta de apoio por parte do governo. Em Israel, o Department for the Investigation of Police Officers (Machash) foi instalado em 1992. Em Washington, o Office of Citizen Complaint Review (OCCR) veio substituir, em 1998, o Civilian Complaint Review Board (CCRB), que funcionou de 1980 a 1995. Na Bélgica, o Comité Permanent de Contrôle des Services de Police (Comité P) foi instituído em 1991. Na Dinamarca, vários Police Complaint Boards foram criados a partir de 1995. Na Nigéria, a Police Service Commission foi instituída em 2001 e teve grande importância no processo de transição da ditadura militar para a democracia. Em Lesoto, a Police Complaints Authority foi instituída em 1999. Na Zâmbia, a Police Public Complaints Authority foi instituída em 1999. Nas Ilhas Maurício, o Complaints Investigation Bureau, foi instituído em 1999. Ainda no sudeste da África, em 2004 estavam em processo de instalação a Police Service Commission, no Quênia, e a Independent Police Complaints Commission, na República do Malaui. No Peru, foi instalada em 2002 a Defensoría del Policía, para receber exclusivamente queixas dos policiais e fazer valer os seus direitos. [Berg, 2005; Goldsmith, 2000; Herzog, 2000; Manby, 2000; O’Rawe e Moore, 2000; Phillips e Trone, 2002]

As ouvidorias de polícia criadas foram tantas que surgiram associações para facilitar o intercâmbio de experiências entre elas. A International Association for Civilian Oversight of Law Enforcement (IACOLE) foi criada em 1985, mas enfrentou problemas operacionais e foi substituída, dez anos depois pela National Association for Civilian Oversight of Law Enforcement (NACOLE), criada em maio de 1995 e voltada principalmente para as ouvidorias de polícia norte-americanas, e pela Canadian 
Association for Civilian Oversight of Law Enforcement (CACOLE), criada em setembro de 1995, com base no Canadá.

Faz-se necessário ressaltar, contudo, que as realidades com que lidam estas ouvidorias podem ser bem diferentes dependendo dos países a que pertencem. Na Inglaterra, por exemplo, o diretor da Police Complaints Authority, relata que em 2001 apenas quatro cidadãos foram atingidos por tiros de policiais ingleses. [Graham, 2003] Um relatório divulgado pela Independent Police Complaints Commission é ainda mais eloqüente: das 100 mortes relatadas, apenas uma se deve a um enfrentamento armado entre a polícia e a vítima. As outras foram causadas por acidentes de automóvel durante perseguição policial, paradas cardíacas ocorridas enquanto as vítimas estavam presas ou outras enfermidades muitas vezes relacionadas com o uso de substâncias estupefacientes, suicídios e outros acidentes, mesmo que tenham acontecido após a vítima ter deixado a delegacia.

$\mathrm{Na}$ Irlanda do Norte, em que a ouvidoria foi instituída para diminuir conflitos sérios entre a polícia e a população, o número de investigações pelo uso indevido de armas de fogo pelas forças policiais foi de 21 em 2001, 11 em 2002, e 5 em 2003. [O’Loan, 2004]

Em Portugal, o último ano em que ocorreu uma morte imputável à polícia no interior das suas instalações é 1996, e o número de cidadãos mortos em situações de intervenção policial foi de 5 em 1996, 1 em 1997, 4 em 1998, 4 em 1999, 3 em 2000 e 2 até julho de 2001. [Maximiano, 2003]

Até o conceito de força excessiva precisa ser relativizado. Em San José, na Califórnia, o Independent Police Auditor, categoriza as lesões resultantes do uso da força quanto a:

- não-visíveis, 
- menores, como algemas apertadas,

- moderadas, como hematomas,

- maiores, como ossos quebrados, lacerações ou outra condição que demande tratamento médico de emergência sendo que, em 2002, nenhuma queixa de uso da força envolveu lesões graves. [Guerrero-Daley, 2004]

Em Los Angeles, nos Estados Unidos, Merrick Bobb, que depois veio a se tornar ouvidor da polícia local, foi designado conselheiro especial do departamento de polícia de Los Angeles, em 1993, com a missão expressa de reduzir os custos de ações penais ocasionadas por má conduta policial. De 1988 a 1992, o governo local foi obrigado a desembolsar 18 milhões de dólares em processos ligados a irregularidades cometidas por policiais. [Walker, 2001]

No Canadá, os agentes policiais são obrigados a preencher um relatório a cada vez que sacam a sua arma, mesmo que nenhum tiro tenha sido disparado. Quando um cidadão é ferido pelo tiro de um policial, este é automaticamente retirado de atividade e investigado pela Divisão de Assuntos Internos e pela Comissão Civil de Reclamação. [Mariano, 1998] Um filme-documentário produzido pela Rede Globo ${ }^{7}$ mostra policiais canadenses que se orgulham de terem se aposentado sem nunca terem precisado sacar uma arma.

Fica difícil comparar estas experiências com a das ouvidorias brasileiras, que contabilizam as mortes anuais de cidadãos pela polícia às centenas e que nem mantém registro do número de disparos irregulares realizados por policiais. Aqui a luta das ouvidorias não é para reduzir despesas com processos judiciais dos governos, mas para levar os policiais infratores ao banco dos réus.

\footnotetext{
${ }^{7}$ Polícia comunitária: o exemplo do Canadá, produzido com o patrocínio da Canadian International Development Agency e do Núcleo de Estudos da Violência da USP, com apoio do Instituto São Paulo Contra a Violência.
} 
A experiência internacional é interessante porque mostra que mesmo sociedades de democracia mais antiga enfrentam o problema do controle e da transparência com relação à atuação policial, e que a maior parte o resolveu por uma solução do tipo ouvidoria, ainda que os parâmetros sejam diferentes. [Phillips e Trone, 2002] Mesmo nos países com mais longa experiência democrática, as ouvidorias de polícia são recentes. Ninguém gosta de perder poder ou independência, e nenhuma polícia do mundo gosta de ser investigada ou controlada por órgãos externos. Nem é só no Brasil, ou em países do terceiro mundo, obviamente, que há preconceito da parte dos policiais contra os defensores dos direitos humanos. O pesquisador canadense Jean-Paul Brodeur relata que no Canadá os policiais se referem à Carta Canadense dos Direitos $e$ Liberdades (CCDL) como a "carta dos bandidos". De maneira semelhante, a recomendação de uma comissão independente encarregada de estudar a polícia da Irlanda do Norte de que todo policial prestasse um juramento de respeitar os direitos humanos causou uma polêmica entre os policiais, e nos Estados Unidos, nem sempre os policiais obedecem à resolução Miranda, que os obriga a informar os suspeitos dos seus direitos. [Brodeur, 2000]

A discussão, agora, não é mais se os vigias devem ser vigiados, mas qual é a forma mais adequada para exercer esta vigilância. Em especial, está em questão saber qual é o poder que deve ser atribuído aos guardas dos guardiões. 


\section{As Ouvidorias no Brasil}

\subsection{Como a instituição das ouvidorias entrou na agenda pública nacional}

No dia 23 de setembro 1989, um sábado, os leitores da Folha de S.Paulo tiveram que se deparar com uma palavra nova e de pronúncia difícil: um artigo anunciava a criação da função de ombudsman do jornal. O primeiro a ocupar o cargo foi o jornalista Caio Túlio Costa, com um mandato de um ano, prorrogável por mais um ano, como o responsável por "ouvir os leitores e resguardar seus direitos". Entre as suas tarefas estava o contato direto com os leitores para levantar as reclamações e esclarecer as dúvidas. "Vou receber pessoalmente entidades, instituições, leitores", anunciava o jornalista naquele dia.

O país se preparava para eleger o novo presidente da república em eleição direta pela primeira vez em três décadas, e colocar um fim ao ciclo autoritário dos presidentes escolhidos pelos militares. O jornal daquele dia fazia um balanço da primeira semana de propaganda eleitoral gratuita: o primeiro turno da eleição, que seria realizado dali a menos de dois meses, no primeiro centenário da Proclamação da República, já polarizava o país em torno dos dois candidatos à frente nas pesquisas de intenção de voto, Fernando Collor de Mello e Luiz Inácio Lula da Silva. As idéias de reivindicação de direitos e de participação popular estavam na moda. A nova Constituição tinha sido aprovada no ano anterior, após intensos debates no Congresso Nacional Constituinte, e no ano seguinte seria aprovado o novo Código de Defesa do Consumidor, que incentivava uma relação mais ética entre as empresas e os consumidores. 
Apesar de alardear, na época, que a Folha de S.Paulo era o primeiro jornal brasileiro a ter um mediador entre o jornal e os seus leitores, a inovação já tinha precedentes em empresas brasileiras e em alguns setores da administração pública. A inspiração veio da instituição criada no Parlamento da Suécia, em 1809, cuja função era representar o povo junto ao governo, e permitir ao parlamento fiscalizar a atuação de juízes e servidores. Em 1945, a Organização das Nações Unidas recomendou a prática a todos os seus países membros com o objetivo de proteger os cidadãos contra preconceitos raciais e injustiças nas relações de consumo. No Brasil, a primeira ombudsman do consumidor foi Maria Lúcia Zulszke, que, a partir de 1985, exerceu a função na Rhodia. [VOLPI, 2002] Mais tarde empresas como os bancos Real e Nacional, a agência de viagens Soletur e o Hospital das Clínicas de São Paulo também instituíram os seus advogados do cliente. Na área de varejo, os supermercados Tulha criaram em janeiro de 1993 a função de "gerente do cliente", exercida pela publicitária Maria Cecília Tortaro e pela assistente social Odúlia Santander de Carvalho, que se alternavam no papel de ombudsman. Poucos meses depois o Grupo Pão de Açúcar anunciava ter também uma ombudsman com cartazes espalhados por todas as lojas da cadeia de supermercados nos quais podia-se ler: "Eu sou você no Pão de Açúcar. Se você tem algo a dizer, fale comigo." Os cartazes estampavam também uma fotografia de Vera Giangrande, que encerrou uma renomada carreira de relações públicas para iniciar, a 3 de maio de 1993, na profissão de ombudsman do Pão de Açúcar, contribuindo bastante para popularizar a instituição no Brasil. Com efeito, pode-se dizer que a Folha de S.Paulo e o Grupo Pão de Açúcar foram os responsáveis pela divulgação do conceito de ombudsman entre nós, no início dos anos 90.

No seu artigo de estréia como novo ombudsman da Folha de S.Paulo, Caio Túlio Costa fez uma pequena reflexão sobre o seu novo papel. Após dizer que o cargo de 
ombudsman estreou na imprensa em 1967, no Louisville Courrier Journal, no estado norte-americano do Kentucky, e que mais de 50 jornais no mundo já haviam adotado a prática, entre os quais o The Washington Post, a partir de 1970, e o espanhol El Pais, em 1985, o jornalista reproduziu uma reflexão de Ben Bagdikian, ombudsman do The Washington Post. Num artigo de 1972, ainda no cargo, este teria comentado: "A idéia é um pouco louca - uma instituição pagando alguém para criticá-la em público. Um jornal honesto demitiria um crítico de teatro pago pelo teatro, e ainda assim o crítico de imprensa recebe salário do alvo de suas críticas. Mas não há muita alternativa." Um texto de propaganda do Pão de Açúcar que divulgava o papel da sua mais nova colaboradora fazia uma reflexão parecida: "Ela entra em nossas lojas, apalpa as frutas, confere a limpeza, verifica os preços, aponta os defeitos para o gerente. Depois sai, sem comprar nada. O que a gente faz com uma mulher dessas? A gente paga para ela fazer isso." [VOLPI, 2002]

Em conseqüência dessas primeiras experiências, em março de 1995 foram aprovados os estatutos da Associação Brasileira de Ouvidores/Ombudsman - ABO, com o objetivo de congregar os ouvidores brasileiros, divulgar a instituição da Ouvidoria e relacioná-la com o "aprimoramento democrático e a defesa dos cidadãos", fornecer ajuda para a criação de futuras ouvidorias e oferecer apoio àquelas já existentes, bem como promover intercâmbio com instituições semelhantes de outros países $^{8}$. Atualmente, a ABO conta com cerca de 380 associados em todo o Brasil, com

\footnotetext{
${ }^{8}$ Veja-se por exemplo o texto do Art. $2^{\circ}$ do Capítulo Primeiro do referido estatuto:

"Art. $2^{\circ}$ - A "ABO" fica instituída com as seguintes e primordiais finalidades:

a) Congregar todos os profissionais que exerçam as atividades e funções de Ouvidor "ombudsman" - assim como aqueles que exerçam atividades afins dentro do campo de defesa da cidadania, dos direitos individuais e do meio ambiente.
} 
atuação na administração pública (União, Estados e Municípios) em órgãos da administração direta, indireta e concessionárias e nas empresas privadas das mais diversas atividades. ${ }^{9}$ Faz-se necessário ressaltar, contudo, que as empresas privadas adotam preferencialmente a palavra sueca ombudsman para definir esta atividade, que relacionam às áreas de marketing e relações públicas ${ }^{10}$, enquanto que nos órgãos públicos prefere-se o termo ouvidoria, velho conhecido dos estudiosos da administração pública nos tempos do Brasil colônia.

Com efeito, por ocasião do estabelecimento do primeiro governo geral no Brasil, em 1549, os portugueses trouxeram da metrópole a instituição da ouvidoria-geral. Segundo os registros históricos, o primeiro a exercer a função de ouvidor-geral foi Pero Borges, designado por ocasião da nomeação de Tomé de Sousa como governador do Brasil. [SALVADOR, 1965; VIANNA, 1966] Faz-se necessário lembrar, também, que por ocasião do estabelecimento das capitanias hereditárias, em 1534, as instruções do rei de Portugal aos donatários consignadas nas cartas de doação incluíam, entre outros poderes, o de nomear ouvidores. O historiador Capistrano de Abreu descreveu da seguinte maneira este cargo: "Ao ouvidor da capitania, com ação nova a dez léguas de

b) Tornar conhecida, apreciada e respeitada a instituição da Ouvidoria, como instrumento de aprimoramento democrático e defesa dos cidadãos.

c) Colaborar na criação de Ouvidorias em qualquer campo de atividade em que elas se fizerem necessárias.

d) Defender a instituição da Ouvidoria, assim como os profissionais que nela militam, contra os abusos e pressões de qualquer natureza, que possam prejudicar seu livre exercício.

e) Prestar colaboração com as autoridades e a comunidade, em assuntos de interesse público e sempre que estiver em jogo o interesse da cidadania.

f) Promover intercâmbio cultural, social e de experiências com suas congêneres do País e do Exterior. "

\footnotetext{
${ }^{9}$ A Associação Brasileira de Ouvidores/Ombudsman mantém uma página na internet, no endereço www.abonacional.org.br

${ }^{10}$ Ver GIANGRANDE e FIGUEIREDO, 1997; GIANGRANDE, 1997; CESCA, 2000.
} 
sua assistência e agravo e apelação em toda ela caberia o mesmo papel histórico dos juízes de fora no além-mar”, e acrescenta que, muitas vezes, os ouvidores eram os próprios capitães-mores. [ABREU, 2000]

Não se tratava, portanto, do que entendemos hoje em dia por ouvidoria. Naquela época, e em todo o período colonial, o ouvidor era um funcionário da coroa incumbido de julgar e administrar a justiça. De acordo com Martins Júnior, autor de História do Direito Colonial, "os altos interesses da justiça, isto é, as aplicações das regras de direito aos casos ocorrentes, ficavam a cargo do ouvidor-geral — magistrado incumbido de julgar e punir, na maior parte dos casos sem apelação nem agravo, mas em alguns com audiência do governador, em toda a extensão do território colonizado". [BANDECCHI et alii, 1970] ${ }^{11}$. Sérgio Buarque de Holanda lembra, ainda, que o poder do ouvidor-geral não se limitava à administração da justiça, principalmente quando substituía o provedor-mor, por falecimento ou qualquer impedimento deste. ${ }^{12}$ Com o passar do tempo, o sistema de justiça colonial se tornou cada vez mais estruturado, e o ouvidor se tornou, aos poucos, um fiscal dos funcionários do rei, sem perder de todo, contudo, o direito de proferir sentenças. [LACERDA, 2000]. Uma conseqüência dessa longa experiência histórica, é que o termo “ouvidor” permaneceu na língua portuguesa com o significado alternativo de "juiz de direito". [HOUAISS, 2001]

\footnotetext{
${ }^{11}$ Ver também FAORO, 1996; WEHLING, 1994; VAINFAS, 2000.

${ }^{12}$ Sérgio Buarque de Holanda explica da seguinte maneira as prerrogativas do ouvidor-geral: " $D a$ Ouvidoria em particular, é lícito dizer, como das Audiências das Índias de Castela, que não se limita à administração da justiça, mas exerce, além disso, importantes funções de governo. Ao governador-geral não cabia, por exemplo, anistiar ou castigar os réus ou imiscuir-se de qualquer forma em atribuições da competência do ouvidor. Este conhecia por ação nova dos casos crimes e tinha alçada até morte natural, inclusive, nos escravos, gentios e peões cristãos livres. Nos casos, porém, em que, segundo o direito, cabia a pena de morte inclusive, nas pessoas das ditas qualidades, procederia nos feitos a final, e os despacharia com o governador sem apelação nem agravo, sendo ambos conformes nos votos. Caso discordassem, deveriam mandar os autos com os réus ao corregedor da Corte. Nas pessoas de maior qualidade teria alçada, o mesmo ouvidor, até cinco anos de degredo, excluindo-se, de qualquer modo, de sua ação, as pessoas eclesiásticas. (...) Esses amplos poderes de que dispunha o ouvidor podiam, eventualmente, dilatar-se muito mais quando lhe acontecesse substituir o provedor-mor, por falecimento ou qualquer impedimento deste. Foi, aliás, o que já se deu com o próprio Dr. Pedro Borges: este, ao tempo do governador D. Duarte da Costa, chega a acumular, com os da Justiça, os negócios da Fazenda e o mesmo há de ocorrer com seu sucessor, o licenciado Brás Fragoso, que chegará ao Brasil no ano de 1550 em companhia do bispo D. Pedro Leitão." [HOLANDA, 1960]
} 
Fato significativo, quando se começou a cogitar a implantação de uma instituição política similar ao ombudsman sueco, os termos empregados para designar o novo cargo eram mais próximos de uma tradução da expressão sueca que da palavra portuguesa “ouvidoria”. De acordo com a sistematização elaborada por Manoel Eduardo Camargo e Gomes [GOMES, 2000], e da qual passamos a destacar os pontos mais importantes, já em 1823, ou seja, apenas 14 anos após a iniciativa sueca, o deputado constituinte brasileiro José de Souza Mello apresentou um projeto que estabelecia, em seu art. $5^{\circ}$ :

"Para desafogo, e liberdade dos povos, haverá em cada província um Juízo do Povo, a quem recorra nos casos de opressão para apresentar na Corte as suas queixas, o que o mesmo Juiz do Povo deverá fazer ex-officio."

O debate público sobre essa questão, contudo, só voltou a acontecer a partir da década de 60 do século vinte, quando várias iniciativas, pronunciamentos e artigos aludiam à instituição sueca. Segundo o Decreto $\mathrm{n}^{\mathrm{o}}$ 50.533, de 1961, por exemplo, revogado antes mesmo de ser colocado em prática, seriam implantados nas capitais estaduais Sub-Gabinetes da Presidência da República, com a atribuição, entre outras, de encaminhar aos órgãos pertinentes da Administração Federal "reclamações, pedidos $e$ papéis de interesse das populações locais”.

Posteriormente, em 1977, a Comissão de Valores Mobiliários do Ministério da Fazenda criou no seu quadro de pessoal um cargo de ombudsman, que também não chegou a ser preenchido.

Datam dessa época as primeiras referências bibliográficas nacionais sobre o ombudsman. O primeiro livro sobre a matéria, Ombudsman, corregedor administrativo: a instituição escandinava que o mundo vem adotando, de autoria de Celso Barroso 
Leite, foi editado em 1975. No mesmo ano, João de Oliveira Filho apresentou, na V ${ }^{\mathrm{a}}$ Conferência da Ordem dos Advogados do Brasil, a primeira tese propondo a criação do cargo de Promotor-Geral da Nação, claramente inspirado na instituição sueca.

Ainda de acordo com o relato de Gomes, no final dos anos 70, quando a resistência ao governo militar implantado em 1964 ganhava cada vez mais adeptos, os pronunciamentos na Câmara dos Deputados e no Senado se intensificaram culminando em 1981 no Projeto de Emenda Constitucional n 78 de autoria do deputado Mendonça Neto (PMDB/AL), que propunha a criação de uma Procuradoria Geral do Povo, com a atribuição de "defender os direitos fundamentais em face de atos ilegais da Administração”. Em 1982, contudo, a emenda foi arquivada por decurso de prazo. No mesmo ano, outra proposta de autoria do deputado José Costa (PMDB/AL), sugeria a criação de uma Procuradoria-Geral do Legislativo.

À medida que o fim do regime militar se tornava patente, cresciam as reivindicações por uma maior participação popular e por mecanismos de controle do poder. Em conseqüência, várias propostas de implantação de um ombudsman foram elaboradas e algumas até foram apresentadas no Congresso Nacional. Destacam-se os projetos do senador Luiz Cavalcante (PDS/AL), que propunha a instituição de um ombudsman; do deputado Ney Lopes (PDS/RN); do deputado Jonatas Nunes (PMDB/PI), que sugeria a criação de uma Procuradoria Popular nos moldes do ombudsman sueco; e do senador Marco Maciel (PDS/PE), com a proposta de instituição de um Ouvidor-Geral ${ }^{13}$.

\footnotetext{
${ }^{13}$ Veja-se, por exemplo o texto do art. $2^{\circ}$ do projeto do Senador Marco Maciel, de 1984: "Art. $2^{\circ}$ Incluem-se entre as atribuições do Ouvidor-Geral:

I - velar pelo cumprimento da lei e demais disposições por parte da Administração;

II - proteger o cidadão com relação às ações e omissões lesivas a seus interesses, quando atribuídas a titular responsável por cargo ou função pública;

III - receber e apurar queixas ou denúncias apresentadas por quem se considere prejudicado por ato da Administração;

IV - zelar pela celeridade e racionalização dos procedimentos administrativos;
} 
Gomes destaca que, apesar de as condições de sua implantação e da forma de elegibilidade afastarem este projeto do modelo sueco, permanece bem marcada a inspiração no ombudsman daquele país. ${ }^{14}$

Quando, em 1982, os candidatos oposicionistas venceram as eleições para o governo dos estados mais importantes do país, tornou-se patente a necessidade de permitir que os segmentos mais organizados da sociedade civil tivessem participação efetiva nas decisões políticas. As portas foram abertas, contudo, apenas para setores não-estratégicos da organização estatal. Foram criados conselhos e outros órgãos de controle da decisão política nas áreas de assistência social e comunitária, mas os setores que regulam o tesouro, a administração, o planejamento e o orçamento público, continuaram hermeticamente fechados para qualquer tipo de controle externo.

Nesse contexto é que o governo federal tomou a iniciativa de criar o cargo de Ouvidor-Geral da Previdência Social, através do Decreto n 92.700, de maio de 1986. "Se cada cidadão tem o direito de fiscalizar, cada servidor público tem o dever de aceitar essa fiscalização”, advertiu o presidente da República, José Sarney, na ocasião, afirmando ainda que "as medidas adotadas subordinam os serviços do Estado ao controle democrático por parte da sociedade." $\mathrm{O}$ art. $2^{\circ}$ desse decreto estabelecia:

“Art. $2^{\circ}$. Ao Ouvidor serão levadas as informações, queixas e denúncias dos usuários do Sistema Nacional de Previdência e Assistência Social, cabendolhe zelar pela boa administração dos serviços previdenciários e sugerir medidas com esse objetivo".

\footnotetext{
$V$ - criticar e censurar atos da Administração Pública e recomendar as correções e melhoria do serviço público imóvel em geral;

VI - defender a ecologia, os direitos do consumidor e demais interesses do cidadão." (PLS n' 266/84)

${ }^{14}$ Ver os art. $1^{\circ}$, parágrafo único, e art. $3^{\circ}$ do referido projeto.
} 
Conquanto louvável o intento, como testemunha Gomes, foram postergados alguns elementos essenciais na estruturação do órgão, o que acabou por comprometer integralmente os resultados da iniciativa.

Alguns meses depois, por meio do Decreto $\mathrm{n}^{\circ}$ 93.714, de 15 de dezembro de 1986, o governo federal instituiu a Comissão de Defesa dos Direitos do Cidadão (Codici), subordinada à Presidência da República e composta por servidores do Gabinete Militar, da Consultoria-Geral da República, da Secretaria de Administração Pública da Presidência da República e do Gabinete Civil, todos nomeados pelo presidente da República, com o objetivo de promover a "defesa de direitos do cidadão contra abusos, erros e omissões na Administração Federal”. A descrição das atribuições dessa comissão está muito próxima do modelo do ombudsman sueco de oferecer meios para o controle da administração pública, mas as semelhanças param por aí. Faltavam a independência entre os membros da comissão e o governo federal, por um lado, e a garantia de liberdade para denunciar o funcionamento inadequado da administração federal, por outro lado. $\mathrm{O}$ art. $5^{\circ}$ do referido decreto, por exemplo, dispunha que:

"Art. 5 - Parágrafo único. É vedado à Codici, sem expressa autorização presidencial, dar divulgação a fatos sob sua avaliação ou apreciação."

Pelo mesmo decreto, no seu art. $8^{\circ}$, parágrafo único, ficava também estabelecido que o relatório anual das atividades do conselho só seria remetido ao Congresso Nacional e ao Tribunal de Contas após censura do presidente da República.

Faz-se necessário lembrar, também, o projeto de reforma administrativa apresentado pelo ministro da Administração, Aluízio Alves, em 1985, que sugeria a criação de uma defensoria do interesse público. Com efeito, segundo o texto do referido projeto, tratava-se de "adaptar à realidade nacional um mecanismo surgido nos países nórdicos, posteriormente adotado por extensivo rol de nações democráticas e que diz 
respeito à organização de efetivos canais de reclamação do público sobre a Administração" ${ }^{15}$.

Na mesma época, nas diretrizes de governo do Estado do Paraná, foi igualmente prevista a criação de uma Ouvidoria-Geral do Estado, tendo como principal objetivo a garantia dos cidadãos para o pleno exercício de seus direitos com relação à administração pública: "O que se pretende é algo semelhante ao ombudsman sueco, incumbido de apurar queixas contra a administração pública, instituição já implantada em numerosos governos" 16 .

Nenhuma das duas iniciativas que acabamos de mencionar, contudo, foi implementada. A primeira experiência concreta de institucionalização do ombudsman na administração pública brasileira aconteceu no município de Curitiba, de acordo com o testemunho de Manoel Eduardo Camargo e Gomes, que foi o seu coordenador. Nas suas palavras: “o caráter quase plebiscitário das eleições municipais de 1985, além de traduzir o desejo popular pelo término do regime militar, carregava um pleito pela moralização, transparência e controle do Poder Público Municipal, antes confiado a prefeitos nomeados pelo presidente da República, em face do regime constitucional de exceção" [GOMES, 2000]. Assim, de acordo com o depoimento deste autor, a opção por uma racionalidade material, presa aos valores da democracia, impunha-se no discurso eleitoral do partido de oposição em todo o território nacional. O então prefeito Roberto Requião, seduzido pelas Constituições de Portugal e da Espanha, promulgadas respectivamente em 1976 e 1978, no processo de redemocratização daqueles países, propôs a análise da conveniência da criação de um instituto assemelhado ao Provedor de Justiça e ao Defensor del Pueblo. Os novos titulares do poder logo perceberam que a

\footnotetext{
${ }^{15}$ Diretrizes para a organização da Administração Pública Federal. Brasília, Câmara 1, Comissão Geral de Reforma do Estado, 1985, p. 8, apud GOMES, 2000.

${ }^{16}$ Partido do Movimento Democrático Brasileiro. Diretrizes de Governo. Curitiba, Fundação Pedroso Horta, 1986, p. 94, apud GOMES 2000.
} 
questão central era transformar a estrutura administrativa municipal, comprometida por duas décadas de clientelismo e dominada pelas elites locais, e que sem a enfrentar o seu governo não seria muito diferente dos anteriores.

A estratégia dos idealizadores desta experiência pioneira foi começar por uma experiência-piloto de seis meses, durante a qual poderiam aperfeiçoar os seus mecanismos e aparar as arestas que dificultavam a sua implantação definitiva. A 8 de março de 1986, foi apresentado ao prefeito o Projeto-Piloto de Implantação da Ouvidoria Municipal de Curitiba, em cuja introdução explicava-se que "o projeto pretende aferir as possibilidades e conveniências técnicas de adequação dessa instituição de origem escandinava à realidade de Curitiba, criando condições para um estudo de caráter experimental (...) os dados necessários serão levantados em seis meses de funcionamento institucional precário para elaborar, no próximo semestre, um projeto definitivo." Após ser aceito pelo prefeito, o projeto deu origem ao decreto $n^{\circ} 215 / 86$, assinado a 21 de março de 1986, que instituiu a Ouvidoria-Geral do Município de Curitiba, subordinada ao executivo municipal. ${ }^{17}$ Verificado o funcionamento satisfatório da experiência, elaborou-se um projeto de lei que vinculava a ouvidoria ao poder legislativo, de maneira a dar maior independência à nova instituição. Desentendimentos entre o poder legislativo e o executivo, no entanto, não permitiram que o projeto fosse apreciado pela Câmara Municipal de Curitiba. Foi preciso esperar a aprovação da Lei Orgânica do Município, de 10 de abril de 1990, para ver a ouvidoria consagrada em seu

\footnotetext{
${ }^{17}$ As atribuições do ouvidor-geral estavam descritas no art. $2^{\mathbf{o}}$ :

"Art. $2^{\circ}$ Atuando na defesa dos direitos e interesses individuais e coletivos contra atos e omissões ilegais ou injustos cometidos pela Administração Pública Municipal, compete ao Ouvidor-Geral:

I - receber e apurar a procedência das reclamações ou denúncias que lhe forem dirigidas e determinar; quando cabível, a instauração de sindicâncias, de inquéritos administrativos e de auditorias aos órgãos competentes;

II - recomendar a anulação ou correção de atos contrários à lei ou às regras da boa administração representando, quando necessário, os órgãos superiores competentes;

III - sugerir medidas de aprimoramento da organização e das atividades da Administração Pública Municipal, em proveito dos administradores”.
} 
art. 64 como "órgão autônomo de controle interno e de defesa dos direitos e interesses dos cidadãos, vinculado ao poder legislativo". Lamentavelmente, este dispositivo, que nunca chegou a ser regulamentado, serviu de pretexto a Jaime Lerner, sucessor de Roberto Requião na prefeitura de Curitiba, para extinguir a ouvidoria municipal que vinha funcionando até então sob a alçada do poder executivo.

Os exemplos anteriormente citados mostram que o tema do controle da administração pública e a instituição de ouvidorias calcadas no modelo do ombudsman sueco eram assuntos presentes na agenda pública do país no momento da passagem do autoritarismo para a democracia. Como não podia deixar de ser, o assunto esteve presente nas discussões dos constituintes e nos debates para a elaboração da nova Constituição. Gomes menciona que o anteprojeto elaborado pela Comissão Provisória de Estudos Constitucionais, presidida por Afonso Arinos, propunha a instituição de uma Defensoria do Povo, de características muito semelhantes ao ombudsman sueco. ${ }^{18} \mathrm{O}$ texto definitivo, que foi elaborado pelos constituintes abandonando o ante-projeto Arinos e foi aprovado em 1988, contudo, não manteve a Defensoria do Povo e optou por confiar algumas das suas atribuições ao Ministério Público. ${ }^{19}$ No capítulo que

\footnotetext{
${ }^{18}$ A Defensoria do Povo era descrita pelo art. 56:

“Art. 56 - É instituído o Defensor do Povo, incumbido, na forma de lei complementar, de zelar pelo efetivo respeito dos poderes do Estado aos direitos assegurados nesta Constituição, apurando abusos e omissões de qualquer autoridade e indicando aos órgãos competentes as medidas necessárias a sua correção ou punição.

$\S 1^{\circ} \mathrm{O}$ Defensor do Povo poderá promover a responsabilidade da autoridade requisitada no caso de omissão abusiva na adoção das providências requeridas.

$\S 2^{\circ}$ Lei complementar disporá sobre a competência, a organização e o funcionamento da Defensoria do Povo, observados os seguintes princípios:

I-o Defensor do Povo é escolhido, em eleição secreta, pela maioria absoluta dos membros da Câmara dos Deputados, entre candidatos indicados pela sociedade civil e de notório respeito público e reputação ilibada, com mandato renovável de cinco anos;

II - são atribuídos ao Defensor do Povo a inviolabilidade, os impedimentos, as prerrogativas processuais dos membros do Congresso Nacional e os vencimentos dos ministros do Supremo Tribunal Federal;

III - as Constituições Estaduais poderão instituir a Defensoria do Povo, de conformidade com os princípios constantes deste artigo".

${ }^{19}$ Veja-se, os incisos II e III do art. 129 da Constituição Federal:

“Art. 129. São funções institucionais do Ministério Público:

(...)
} 
dispõe sobre a Administração Pública, todavia, os constituintes incluíram a possibilidade de encaminhar reclamações da população sobre a qualidade dos serviços públicos por meio de uma lei ordinária:

“Art. $37-(\ldots)$

$\S 3^{\circ}$ As reclamações relativas à prestação de serviços públicos serão disciplinadas em lei.”

Apesar da pressão do Ministério Público ter sido vitoriosa e o texto constitucional não ter consagrado a instituição de uma ouvidoria nos moldes do ombudsman sueco, este artigo permitiu a implantação de numerosas ouvidorias setoriais, nos ramos mais diversos da administração pública nos níveis federal, estadual e municipal. ${ }^{20}$ Podemos citar, por exemplo, a Ouvidoria-Geral do Ibama, instituída em 1989, a Ouvidoria-Geral da Seguridade Social, de 1991, a Ouvidoria Geral da República, de 1992, no nível federal; a Ouvidoria Pública do Estado do Paraná, de 1991, a Ouvidoria do Estado do Ceará, de 1997, no nível estadual; além de mais de uma centena de ouvidorias municipais e de outra centena de ouvidorias em órgãos da administração, como as ouvidorias de polícia e as ouvidorias universitárias. ${ }^{21}$

\footnotetext{
II - zelar pelo efetivo respeito dos Poderes Públicos e dos serviços de relevância pública aos direitos assegurados nesta Constituição, promovendo as medidas necessárias a sua garantia;

III - promover o inquérito civil e a ação civil pública, para a proteção do patrimônio público e social, do meio ambiente e de outros interesses difusos e coletivos;"

20 Dez anos mais tarde, por meio da Emenda Constitucional $n^{\circ} 19$, de 4 de junho de 1998, este mesmo parágrafo $3^{\circ}$ recebeu nova redação que reforçou o seu sentido:

“Art. $37-(. .$.

$\S 3^{\circ}$ A Lei discipolinará as formas de participação do usuário na administração pública direta e indireta, regulando especialmente:

I - as reclamações relativas à prestação dos serviços públicos em geral, asseguradas a manutenção de serviço de atendimento ao usuário e a avaliação periódica, externa e interna, da qualidade dos serviços;

II - o acesso dos usuários a registros administrativos e a informações sobre atos de governo, observado o disposto no art. $5^{\circ}$, X e XXXIII;

III - a disciplina da representação contra o exercício negligente ou abusivo de cargo, emprego ou função na administração pública."

${ }^{21}$ Ver levantamento da Associação Brasileira de Ouvidores para maiores detalhes.
} 
Faz-se necessário ressaltar que, apesar do longo debate que acabamos de expor sobre a oportunidade de instalar no Brasil uma instituição similar ao ombudsman sueco ter sugerido vários termos para designá-la ${ }^{22}$, a palavra ouvidoria acabou por prevalecer.

Outro fato que merece ser mencionado é que a experiência brasileira, que desembocou num grande número de ouvidorias setoriais ao invés de um ombudsman nacional, a exemplo do modelo sueco, obedece a uma recomendação feita por Anders Wigelius, ombudsman da Suécia para a área $\operatorname{civi1}^{23}$, em visita ao Brasil para participar do $2^{\circ}$ Simpósio Latino-americano de Ombudsman, realizado em Curitiba, em agosto de 1987. Naquela ocasião, ele disse que "O ombudsman no Brasil não deve ter a pretensão de resolver todos os problemas, pois, caso contrário, vai se afogar em reclamações. Ele precisa tomar as iniciativas e solucionar os problemas mais urgentes de forma sensata, passo a passo." 24 Na Suécia, explicou, em função do estágio avançado de desenvolvimento do país, a preocupação básica “é com os direitos e liberdades individuais". Em função dos problemas sociais do Brasil, segundo ele, a atuação do ombudsman aqui tem que ser feita "de uma forma sensata", pois "não se pode querer fazer tudo ao mesmo tempo, porque aí se corre o risco de não resolver nada". Ainda segundo Wigelius, a maior parte dos quatro mil casos que passa a cada ano por seu departamento é relacionada a problemas das esferas policial e penitenciária.

É justamente nessa área que surgiram, na década de noventa, instituições que se constituíram num marco na promoção e defesa dos direitos humanos no país. Com efeito, a partir da criação da Ouvidoria da Polícia do Estado de São Paulo, em meados dos anos noventa, o conceito se difundiu e hoje está presente em vários estados da

\footnotetext{
${ }^{22}$ Juízo do Povo, Promotor-Geral da Nação, Procuradoria Geral do Povo, Procuradoria Geral do Legislativo, Procuradoria Popular, Ombudsman, Ouvidor Geral, Comissão de Defesa dos Direitos do Cidadão, Defensoria do interesse público, Ouvidoria Geral do Estado, Defensoria do Povo.

${ }^{23}$ A Suécia tem quatro ombudsman, que são responsáveis por fiscalizar a atuação do Estado em diferentes áreas (civil, militar, social, impostos). Todos são eleitos pelo parlamento para um período de quatro anos, com direito à reeleição.

${ }^{24}$ Depoimento transcrito pela Folha de S. Paulo, no dia 11 de agosto de 1987, em matéria intitulada

"Ombudsman da Suécia recomenda paciência aos colegas brasileiros".
} 
federação. De acordo com o testemunho de Benedito Domingos Mariano [MARIANO, 2000; TONETO, 2000], a Ouvidoria da Polícia do Estado de São Paulo era um sonho antigo de entidades de direitos humanos paulistas. A idéia de sua criação estava entre as recomendações encaminhadas aos candidatos ao governo de São Paulo, nas eleições de 1994, pelo Conselho Estadual de Defesa da Pessoa Humana (CONDEPE) ${ }^{25}$. A principal proposta deste Conselho para aperfeiçoar o funcionamento das polícias civis e militares consistia na implantação de um mecanismo de fiscalização do trabalho da polícia pela sociedade civil. Os detalhes da proposta constam de uma publicação assinada por três membros do CONDEPE: o padre Francisco Reardon, da Pastoral Carcerária; Carlos Weis e Benedito Domingos Mariano, representante do Centro Santo Dias. ${ }^{26}$ Dentre as propostas de ações governamentais para reestruturar as polícias, constam:

1. salário digno aos policiais;

2. proteção para as famílias dos policiais;

3. cursos sobre direitos fundamentais da pessoa humana;

4. não premiar policiais acusados pelo uso ilegal da violência fatal;

5. orientação de evitar ferimentos fatais em suspeitos;

6. controle externo das polícias;

7. autonomia dos órgãos periciais;

8. condução dos inquéritos;

9. uma única polícia de caráter civil;

10. enquadramento da justiça militar estadual;

11. polícia comunitária nas ruas, não nos quartéis.

\footnotetext{
${ }^{25} \mathrm{O}$ CONDEPE é formado por dez pessoas, sendo seis representantes de entidades de direitos humanos, dois representantes da seccional da Ordem dos Advogados do Brasil, um representante do Legislativo e um do Executivo estaduais. Fermino Fecchio chama a atenção para o fato de o CONDEPE ser o único conselho do estado no qual predomina a sociedade civil, pois dos dez conselheiros com direito a voto, oito pertencem à sociedade civil.

${ }^{26}$ O Centro Santo Dias de Direitos Humanos da Arquidiocese de São Paulo foi criado em 1979, depois da morte do operário católico Santo Dias da Silva. Esta entidade tem desenvolvido um trabalho importante na luta contra a violência policial na cidade de São Paulo.
} 
O item relativo ao controle externo das polícias era detalhado da seguinte maneira:

"A polícia deve ser controlada pela sociedade no que se refere à violação dos Direitos Humanos, através do Conselho Estadual de Defesa dos Direitos da Pessoa Humana, Ministério Público e Poder Judiciário. As Corregedorias devem trabalhar em parceria com a sociedade civil, de modo transparente e não corporativo." [Mariano, Reardon, Weis, 1994]

O texto foi encaminhado aos dois candidatos que disputaram o segundo turno das eleições estaduais de São Paulo naquele ano: Francisco Rossi (PL) e Mário Covas (PSDB). O primeiro dispensou a ajuda do CONDEPE, afirmando já ter um plano de segurança pública elaborado. O segundo aceitou debater a proposta, por meio da sua equipe de campanha.

Ao ser eleito governador de São Paulo, Mário Covas inaugurou sua administração com a assinatura, no primeiro dia de trabalho, $1^{\circ}$ de janeiro de 1995 , do decreto $\mathrm{n}^{\mathrm{o}}$ 39.900, que criou a Ouvidoria da Polícia do Estado de São Paulo. ${ }^{27}$ Foi preciso esperar quase um ano, contudo, para que a ouvidoria fosse efetivamente instalada e começasse a funcionar. Entre as razões para a demora estão a novidade do controle externo e as resistências corporativas e políticas. Muito embora a instalação da

${ }^{27}$ As atribuições da Ouvidoria da Polícia eram detalhadas no art. $2^{\circ}$ do referido decreto:

"Art. $2^{\circ}$ - A Ouvidoria da Polícia tem as seguintes atribuições:

I- ouvir as reclamações de qualquer do povo contra abusos de autoridades e agentes policiais, civis e militares.

II - receber denúncias contra atos arbitrários e ilegais, neles incluídos os que atentem contra a moralidade pública, bem como qualquer ato de improbidade administrativa, praticados por servidores públicos de qualquer natureza, vinculados à Secretaria da Segurança Pública.

III - promover as ações necessárias à apuração da veracidade das reclamações e denúncias e, sendo o caso, tomar as medidas necessárias ao saneamento das irregularidades, ilegalidades e arbitrariedades constatadas, bem como para a responsabilização civil, administrativa e criminal, dos imputados.

Parágrafo único - A Ouvidoria da Polícia manterá sigilo da fonte e a proteção do denunciante, quando for o caso." 
ouvidoria fosse um desejo pessoal do governador, as resistências não puderam ser contornadas imediatamente. Segundo o relato da jornalista Bernadete Toneto, baseado num depoimento de Benedito Domingos Mariano:

"temendo que a iniciativa não saísse do papel, os membros do CONDEPE, em reunião com o então Secretário de Segurança Pública, José Affonso da Silva, questionaram a demora da implementação do organismo. Em reunião de quase quatro horas, ouviram do Secretário uma justificativa incontestável: o governo do Estado não encontrara, ainda, a pessoa ideal para assumir o novo projeto, ou seja, uma pessoa vinculada aos grupos de direitos humanos que aceitasse um trabalho em tempo integral, recebendo por isso um salário exíguo. Além disso, a principal característica do futuro Ouvidor deveria ser a determinação em criar a primeira Ouvidoria de Polícia do país, em um Estado cujas polícias marcavam sua ação pela repressão e com longa folha corrida de torturas e abusos."

Nessa mesma reunião, o secretário da segurança pública José Affonso da Silva pediu ajuda aos membros do CONDEPE para encontrar a pessoa adequada para o cargo de ouvidor da polícia do Estado de São Paulo. O advogado Antonio Carlos Malheiros, membro da Comissão Justiça e Paz de São Paulo, sugeriu o nome do SecretárioExecutivo do Centro Santo Dias, Benedito Domingos Mariano. Antes de aceitar a missão de implantar a primeira ouvidoria de polícia do país, no entanto, Mariano se encontrou com várias personalidades da área dos direitos humanos e convidou-as para integrar um conselho consultivo da futura ouvidoria. De acordo com o depoimento já citado, a intenção era que "o novo organismo fiscalizador da ação policial tivesse completa autonomia e independência, e que suas ações fossem definidas não apenas pelo titular do cargo, mas por representantes da sociedade civil”. Foi exigido, também, 
que o ouvidor tivesse completa autonomia e independência de trabalho e que, inicialmente, a ouvidoria funcionasse nas dependências do gabinete do Secretário da Segurança Pública, para mostrar força política. Faltava, ainda, o aval do cardeal dom Paulo Evaristo Arns, sócio-fundador do Centro Santo Dias de Direitos Humanos. Para Benedito Domingos Mariano, na época diretor afastado do Centro, no qual trabalhou durante 14 anos, "o aval do cardeal dos direitos humanos era fundamental, pois significava o reconhecimento do trabalho desenvolvido até então, de defesa de familiares e vítimas da violência policial”.

O cardeal dom Paulo Evaristo Arns não só concordou com a nomeação de Mariano para a ouvidoria recém criada, como deu uma demonstração explícita de apoio ao participar da cerimônia de posse, no dia 20 de novembro de 1995 , realizada, a seu pedido, no Palácio dos Bandeirantes, sede do governo estadual. "Assim," de acordo com Mariano, "aquela que seria uma simples solenidade de posse de segundo escalão, prevista para as dependências da Secretaria de Segurança Pública, tornou-se um ato político cujas dimensões extrapolaram os muros do Palácio: estavam presentes o Governador Mário Covas, seus secretários, os titulares das polícias civil e militar e os responsáveis por autarquias e empresas estatais." Nessa ocasião, o futuro ouvidor da polícia do Estado de São Paulo recebeu do governador a garantia da permanência no cargo enquanto durasse o seu mandato. "De certa forma," afirma Mariano, "ele me deu um mandato. Garantiu que, se eu sofresse pressão, teria respaldo institucional do governo."

Nesse mesmo dia, Mariano anunciou que a ouvidoria realizaria relatórios trimestrais de prestação de contas e os tornaria públicos. O primeiro relatório foi divulgado a 29 de fevereiro de 1995, em uma coletiva de imprensa. A razão para tornar públicos os resultados das atividades era ressaltar a transparência da ouvidoria, que 
assim "presta contas de sua ação à sociedade e ao Governo, sem qualquer tipo de censura prévia a esse tipo de fiscalização da ação policial, autônoma e independente do Executivo estadual", de acordo com o seu primeiro titular.

A criação de uma sistemática de trabalho na primeira ouvidoria de polícia do país, contudo, não foi nada fácil, como mostra o depoimento de Fermino Fecchio, que posteriormente foi assessor de Mariano e o sucedeu na ouvidoria:

"O Mariano começou a funcionar em novembro. Mas veja, ele começou sem estrutura. Não tinha uma definição legal, não tinha cargos, não tinha carreiras, não tinha nada. O Mariano não podia nem escolher os assessores dele. Ele tinha em mãos o pessoal que tinha na casa. Então ele começa a trabalhar com funcionários das próprias instituições policiais. Ele emprestava um escrivão, emprestava um datilógrafo. Não tinha sala, não tinha mesa, não tinha cadeira, não tinha telefone, não tinha nada. É assim que começa. (...) E era difícil vencer as resistências. Era absoluta novidade. Imagina um delegado responder ao ouvidor, ter que atender o ouvidor." 28

Desde o começo, contudo, o grupo do CONDEPE tinha consciência de que a instalação da ouvidoria por decreto não era o ideal. Pois um decreto não é muito consistente, pode ser facilmente revogado. Logo se buscou, portanto, elaborar um projeto de lei para substituir o decreto de instituição da ouvidoria, dando-lhe assim maior respaldo legal. Redigido com base na experiência dos seis primeiros meses de funcionamento da ouvidoria, e apresentado ao secretário de segurança pública, o projeto ficou engavetado por dez meses. Foi necessário um fato político de repercussão

\footnotetext{
${ }^{28}$ Depoimento dado ao autor a 2 de junho de 2005.
} 
nacional para que o texto saísse do esquecimento e fosse colocado em lugar de destaque na agenda política estadual.

Trata-se do episódio da Favela Naval, que chocou o país e provocou comoção nacional. Na noite do dia 31 de março de 1997, foram divulgadas pelo Jornal Nacional, da TV Globo, imagens gravadas por um cinegrafista amador, nas madrugadas dos dias 3 e 5 de março, de Policiais Militares torturando, espancando e extorquindo dinheiro de nove pessoas, matando uma delas, na Favela Naval, no município de Diadema, em São Paulo. Na operação, um soldado conhecido como Rambo, que chefiava o grupo, matou a tiros o mecânico Mário José Josino, uma das nove vítimas. Um rapaz que vestia camisa listrada levou 34 pancadas de cassetete em apenas 3 minutos. No dia seguinte, o ministro da Justiça, Nélson Jobim, classificou de "monstruosa" a operação exibida pela televisão, e disse que o governo "repudiava veementemente qualquer tipo de violação dos direitos do cidadão". O governador Mário Covas, que só soube pela televisão dos atos de crueldade de sua PM, pediu desculpas à sociedade. Os 10 policiais, que pertenciam ao $24^{\circ}$ Batalhão da $\mathrm{PM}$ paulista, tiveram imediatamente prisão temporária decretada. A maioria deles já havia cometido outros crimes. Experiente em lidar com denúncias contra policiais criminosos, o promotor Fernando Barione Nucci, corregedor do Tribunal de Justiça Militar de São Paulo e designado para formular a denúncia contra o grupo de Diadema, disse que “já tinha visto este filme muitas vezes. Ele só não havia sido exibido ainda na televisão". ${ }^{29}$

As cenas do massacre de Diadema foram exibidas pela televisão no mundo inteiro e chamaram a atenção da Anistia Internacional, que decidiu enviar uma comissão especial para acompanhar as investigações. A Comissão de Direitos Humanos da

\footnotetext{
${ }^{29}$ De acordo com relato publicado pelo Jornal do Brasil de 2 de abril de 1997 em matéria intitulada "Cenas do massacre de Diadema são exibidos pela televisão no mundo inteiro".
} 
Câmara dos Deputados criou uma CPI para investigar a violência policial em todo o país. No dia 2 de abril, a Comissão de Constituição e Justiça do Senado Federal aprovou um projeto de lei que classifica tortura como crime. O projeto, de autoria do poder executivo e já aprovado pela Câmara dos Deputados, estava parado havia seis meses, apesar do pedido de urgência feito em maio de 1996, e foi aprovado por unanimidade em votação simbólica no senado, no dia 3 de abril. ${ }^{30}$ Até então, a legislação brasileira considerava a tortura apenas lesão corporal. A nova lei considera crime de tortura qualquer ato de violência praticado por agente público ou não contra uma pessoa com o objetivo de obter informações, delações, testemunho ou confissão. Também estão sujeitos a punição, de até 16 anos de prisão, aqueles que assistirem aos crimes de tortura sem evitá-los ou denunciá-los. Com o novo projeto, o país passou a se enquadrar nos acordos internacionais assinados pelo governo brasileiro em defesa dos direitos humanos. No mesmo dia 3 de abril, a Comissão de Constituição e Justiça (CCJ) da Câmara dos Deputados aprovou um projeto de emenda constitucional que remete à Justiça Federal os crimes contra os direitos humanos, atualmente julgados pelos estados onde foram praticados. A emenda estava parada na CCJ desde junho de $1996 .{ }^{31}$ Foi acelerada, também, a tramitação de outros dois projetos de lei na Câmara dos Deputados, um deles do deputado Hélio Bicudo (PT-SP) e o outro, de autoria do governo federal, que previam a transferência do julgamento de crimes cometidos por policiais militares para a Justiça comum.

\footnotetext{
${ }^{30}$ Simultaneamente, porém, o Jornal da Band, da TV Bandeirantes, mostrava 60 recrutas da Aeronáutica, filmados na Base Aérea de Santa Maria (RS) gritando, durante uma sessão de treinamento, um assustador refrão de ordem-unida: "Tortura é uma coisa/muito fácil de fazer/Pega o inimigo/e maltrata até morrer". O debate sobre o episódio tomou conta do plenário do Senado durante a votação do projeto de lei que define os crimes de tortura.

${ }^{31}$ Quase oito anos depois, esta proposta, conhecida como "federalização dos crimes contra os direitos humanos", ainda não foi aprovada. O texto já passou pela Câmara dos Deputados, onde foi modificado e teve a sua abrangência reduzida, e tramita atualmente no Senado, com apoio do governo federal. Os opositores alegam que a federalização seria uma espécie de "atestado prévio de incompetência" dos Judiciários estaduais em matéria de direitos humanos. [Folha de S. Paulo, 27/01/2004]
} 
O projeto de lei que tipifica o crime de tortura foi sancionado pelo presidente da república no dia 7 de abril. Na mesma ocasião, o executivo federal enviou ao Congresso um projeto de lei que fixa normas e penalidades sobre o abuso de autoridade e anunciou a criação da Secretaria Nacional de Direitos Humanos que tem, entre suas prioridades, a revisão da organização, formação e ação das polícias.

No plano estadual, foi recuperado o texto do projeto de lei que formalizou a Ouvidoria da Polícia do Estado de São Paulo. De acordo com o relato de Benedito Domingos Mariano [TONETO, 2000]:

"A repercussão nacional e internacional do caso Favela Naval obrigou o governo a dar uma resposta política imediata. O episódio deu mais visibilidade à Ouvidoria da Polícia, que ganhou mais espaço nos veículos de comunicação. Na época, a Ouvidoria da Polícia fez questão de divulgar que o caso Favela Naval era seu procedimento número 601, ou seja, outros seiscentos casos de violência policial, tão ou mais graves quanto aquele, já tinham sido denunciados aos órgãos competentes.

Dez dias depois da divulgação das imagens de violência policial em Diadema, foi convocada uma reunião de urgência. Por decisão do governador do Estado, o projeto de lei complementar de criação da Ouvidoria da Polícia seria encaminhado, o quanto antes, para votação na Assembléia Legislativa.

Durante quatro horas, a minuta de justificativa e os detalhes técnicos do projeto elaborado pelo Conselho Consultivo da Ouvidoria da Polícia foram analisados pelos secretários do Planejamento, da Fazenda, de Governo e da Segurança Pública. Pouco depois do almoço, o governador Mário Covas recebia o texto definitivo, que determinava a criação de 16 cargos próprios. 
No dia seguinte, o projeto foi encaminhado à Assembléia Legislativa, em caráter de urgência constitucional. Na Assembléia, o projeto inicial sofreu 44 emendas, das quais 11 foram aproveitadas e aceitas pelo Executivo estadual. O projeto de lei foi aprovado em sessão extraordinária no dia 2 de junho de 1997, sem votos contrários e apenas três abstenções (dos deputados Afanázio Jazadji, Erasmo Dias e Conte Lopes, todos com fortes vínculos com o lobby policial)." O texto final foi assinado por Mário Covas a 20 de junho de 1997 e define que o ouvidor da polícia deve ser escolhido pelo governador a partir de uma lista tríplice elaborada pelo CONDEPE. O ouvidor tem mandato de dois anos e pode ser reconduzido ao cargo uma única vez. ${ }^{32}$

No que diz respeito à ouvidoria da polícia de São Paulo, a repercussão dos acontecimentos de Diadema tiveram, portanto, impacto decisivo na aprovação da lei que a regulamenta. Faz-se necessário ressaltar, também, que o caso da Favela Naval aumentou a visibilidade da ouvidoria que passou a ser mais procurada pela população em geral. Com efeito, o ouvidor da polícia declarou à imprensa que, após o episódio em questão, o número de telefonemas diários atendidos pela sua equipe quadruplicou, passando de 25 para 100, sendo que $60 \%$ das ligações se referiam a denúncias, e a maioria por abuso de autoridade. ${ }^{33}$

Uma conseqüência da institucionalização da ouvidoria da polícia de São Paulo é que o conceito se difundiu e órgãos semelhantes foram implantados em outros estados da federação. Note-se, também, que no Programa Nacional de Direitos Humanos (PNDH), lançado pelo governo federal a 13 de maio de 1996, constava entre as 168 propostas o incentivo à "criação de Ouvidorias de Polícia, com representantes da sociedade civil e autonomia de investigação e fiscalização”. O Pará foi o segundo

\footnotetext{
${ }^{32}$ Trata-se da Lei Complementar $n^{\text {o }} 826$, de 20 de junho de 1997.

${ }^{33}$ Veja-se, por exemplo, a entrevista com o ouvidor publicada no Jornal do Brasil de 7 de abril de 1997.
} 
estado brasileiro a instalar uma ouvidoria, com a nomeação da ouvidora Rosa Marga Rothe, uma pastora luterana com longa militância junto aos movimentos de educação popular e de direitos humanos, em junho de 1997, um ano depois da lei que estabeleceu o órgão (Lei $n^{\circ} 5944$, de 2 de fevereiro de 1996, complementada pelo Decreto $\mathrm{n}^{\mathrm{o}} 1555$, de 9 de agosto de 1996). Vieram, a seguir, em ordem cronológica de implantação:

a Ouvidoria da Polícia do estado de Minas Gerais, instalada em setembro de 1998 (Lei $\mathrm{n}^{\text {o }}$ 12622, de 25 de setembro de 1997, alterada pela Lei $\mathrm{n}^{\circ} 12968$, de 27 de julho de 1998),

a Ouvidoria da Polícia do estado do Rio de Janeiro, instalada em março de 1999 com a nomeação de Julita Lemgruber (Lei nº 3168, de 12 de janeiro de 1999),

- a Ouvidoria da Polícia do estado do Espírito Santo, que teve uma implantação precária e atualmente está sendo reativada ${ }^{34}\left(\right.$ Lei $\mathrm{n}^{\mathrm{o}}$ 5649/98, de 14 de maio de 1998),

a Ouvidoria da Justiça e da Segurança do estado do Rio Grande do Sul, tendo como primeiro ouvidor Luiz Goulart Filho (Decreto no 39.668 , de 17 de agosto de 1999),

- $\quad$ e a Ouvidoria da Polícia do estado do Paraná (Decreto n ${ }^{\circ} 2026$, de 9 de maio de 2000).

Com o objetivo de ampliar estas experiências, foi criado, por meio de um decreto presidencial, a $1^{\circ}$ de junho de 1999, no âmbito da Secretaria de Estado dos Direitos Humanos do Ministério da Justiça, o Fórum Nacional de Ouvidores de Polícia,

\footnotetext{
${ }^{34}$ A lei que instituiu a Ouvidoria da Polícia do Estado do Espírito Santo foi sancionada pelo então presidente da Assembléia legislativa do estado, deputado José Carlos Gratz, cuja reeleição em 2002 foi cassada pelo Tribunal Regional Eleitoral do Espírito Santo, sob acusação de abuso do poder econômico e compra de votos. Gratz também é acusado pelo Ministério Público Federal de ser um dos líderes do crime organizado no estado e foi apontado pela Comissão Parlamentar de Inquérito do Narcotráfico como um dos envolvidos em crime de lavagem de dinheiro, contrabando e homicício. [MESQUITA NETO e AFFONSO, 2002]
} 
com a finalidade de "oferecer sugestões voltadas para o aperfeiçoamento institucional dos órgãos policiais, no que diz respeito à promoção e a proteção dos direitos humanos, e estimular a criação de novas ouvidorias de polícia”, como consta no art. $2^{\circ}$ do referido decreto.

Até o momento, temos o conhecimento da existência de ouvidorias de polícia também nos seguintes estados da federação:

Ouvidoria da Polícia do estado do Mato Grosso (Lei $\mathrm{n}^{\circ}$ 7.286, de maio de 2000, alterada pela Lei $n^{0} 7.885$, de janeiro de 2003),

Ouvidoria da Polícia do estado do Rio Grande do Norte (Lei n ${ }^{0} 7.851$, de junho de 2000),

- $\quad$ Ouvidoria Geral da Polícia do estado de Goiás (Lei n ${ }^{\circ} 14.383$, de 31 de dezembro de 2002),

- $\quad$ Ouvidoria da Polícia Civil do estado do Ceará e Ouvidoria da Polícia Militar do estado do Ceará,

Ouvidoria da Polícia do estado da Bahia,

Ouvidoria Geral da Secretaria de Defesa Social do estado de Pernambuco,

- $\quad$ Ouvidoria da Polícia do estado de Santa Catarina. 


\subsection{Papel do Ministério Público no controle da polícia}

Antes de prosseguir na análise das ouvidorias de polícia, é preciso fazer uma pausa para investigar a relação entre estas e o Ministério Público que, entre outras atribuições, tem também o de fiscalizar o trabalho policial. Com efeito, dentre as funções institucionais do Ministério Público, consagradas pela Constituição de 1988, destaca-se o exercício do controle externo da atividade policial. [CF 1988, Art. 129 VII]

O Ministério Público é um órgão do Estado que defende a sociedade e a lei perante a Justiça, acusando os responsáveis pelos crimes, sejam eles indivíduos particulares ou os próprios agentes públicos. Ao longo da história do país, esta instituição conquistou cada vez maior independência com relação ao Executivo (se antes ela falava em nome do imperador, a quem era subordinada, hoje ela representa a sociedade, defende a lei, promove a justiça e pode inclusive acusar os integrantes do poder executivo) e adquiriu características que a aproximam do Judiciário (como as garantias de vitaliciedade, inamovibilidade, independência funcional, foro especial e irredutibilidade dos vencimentos que são conferidas aos membros do ministério público por influência da magistratura). Vários autores afirmam a oportunidade de acrescentar à clássica separação dos três poderes de Montesquieu um quarto poder que viria a ser o Ministério Público [Bicudo, 1978]. Naturalmente, esta dupla função simultânea de defesa da sociedade e da lei torna ambíguo o trabalho do Ministério Público. Este ponto de vista está muito bem exposto por Piero Calamandrei:

"Entre todos os cargos judiciários, o mais difícil, segundo me parece, é o do Ministério Público. Este, como sustentáculo da acusação, devia ser tão parcial como um advogado; como guarda inflexível da lei, devia ser tão imparcial como 
um juiz. Advogado sem paixão, juiz sem imparcialidade, tal é o absurdo psicológico no qual o Ministério Público, se não adquirir o sentido do equilíbrio, se arrisca, momento a momento, a perder, por amor da sinceridade, a generosa combatividade do defensor ou, por amor da polêmica, a objetividade sem paixão do magistrado." 35

Faz-se necessário ressaltar que, no arranjo institucional atual, o Ministério Público detém o monopólio de propositura da ação penal pública. Daí que, como já dissemos, o Ministério Público é o órgão do Estado que faz a acusação contra os ofensores da lei. Quando a acusação se volta contra o Estado, o Ministério Público está ao lado do cidadão.

Podemos dizer, de maneira bastante simplificada que, na organização do sistema de justiça brasileiro, o promotor acusa, o advogado de defesa defende, e o juiz julga, sendo que a apuração do crime é feita pela polícia. Na proposição de qualquer acusação, o Ministério Público depende, portanto, de um trabalho de investigação policial prévio. Daí uma relação de interdependência entre esses dois órgãos que influencia decisivamente a maneira como o Ministério Público exerce o controle da atividade policial.

Apesar do exercício do controle externo da atividade policial pelo Ministério Público ter sido claramente formulado no texto da Constituição de 1988, na vigência das constituições anteriores o Ministério Público já controlava o trabalho da polícia. Faz-se oportuno lembrar a importante atuação do então Procurador de Justiça do Estado de São Paulo, Hélio Bicudo, no combate ao Esquadrão da Morte, no começo da década de setenta. No livro que escreveu sobre o assunto, Hélio Bicudo relata as dificuldades que enfrentou para identificar e acusar os responsáveis por uma série de crimes, episódios de

\footnotetext{
${ }^{35}$ CALAMANDREI, P. Eles, os juízes, vistos por nós, os advogados. Lisboa, Clássica, 1985. Citado em FERRAZ, A. A. M. C. Ministério Público: instituição e processo. São Paulo, Atlas, 1997.
} 
abuso de autoridade, torturas e até mortes, que atuavam sob a proteção do delegado Sérgio Fleury e maculavam a atuação da Polícia Civil paulista. A luta contra o Esquadrão da Morte no âmbito do Ministério Público paulista teve início por iniciativa e insistência de Hélio Bicudo, que sofreu várias pressões políticas até que o então Procurador-Geral da Justiça o destituiu das investigações, um ano após o início dos trabalhos [Bicudo, 2002]. Apesar da repercussão desse episódio, ao refletir, alguns anos mais tarde, sobre a possibilidade de controle efetivo da polícia pelo Ministério Público, Hélio Bicudo foi taxativo quanto à fragilidade da posição do Ministério Público [Bicudo, 1978]:

“O Ministério Público é o órgão do Estado perante os pretórios. São os seus membros que devem trazer aos juízos e tribunais as provas indispensáveis à condenação dos acusados, na qualidade de autores da ação penal. Na prática, porém, não é isto o que acontece. Na generalidade dos casos, o promotor público nada prova na instrução, pelo simples fato de que, não tendo maior contato com a realidade criminal, limita-se a repetir ou a tentar aprimorar os elementos que lhe são entregues nos inquéritos policiais, indicativos do crime e de sua autoria."

“É precisamente por isto, ou melhor, por se achar o promotor público distanciado das fontes de prova que inúmeros procedimentos, nos quais maiores são os interesses, seja pela posição dos delinqüentes, seja por motivos meramente políticos, encontram resultados negativos nos tribunais. O promotor público, desempenhando o papel de mero repetidor daquilo que antes se fez nas delegacias de polícia não tem, em muitos casos, condições para atender à pretensão punitiva do Estado.”

“É certo que nas pequenas comarcas do Interior do Estado o representante do Ministério Público exerce habitualmente - embora isto dependa 
muito de sua personalidade - eficaz fiscalização sobre os trabalhos policiais. Mas essa atividade não é desempenhada a contento nas varas das grandes comarcas ou da Capital, onde o excesso de serviço constitui óbice considerável. Com isso, o Ministério Público vai perdendo sua condição de autor da ação penal, passando a executar funções subalternas, dependendo, exclusivamente, nas suas atribuições, da maior ou menor eficiência do potencial investigatório da Polícia e sujeitando-se, o que é da maior gravidade, a seu exclusivo arbítrio.” Trata-se, é preciso ressaltar, das reflexões de um procurador de justiça acerca da sua profissão e da posição do Ministério Público, que foram publicadas originalmente em agosto de 1975, no Suplemento do Centenário do jornal O Estado de S. Paulo. Atualmente, passadas três décadas, o Ministério Público ampliou consideravelmente o seu raio de atuação, além de ser uma das instituições que mais se destacam no cenário público nacional. Esse processo de reconstrução institucional passa certamente pelas novas prerrogativas asseguradas pela Constituição de 1988, mas é possível ir mais além e remontar a 1985, ano da regulamentação da ação civil pública, ou até a 1981, quando foi aprovada a Lei $\mathrm{n}^{\mathrm{o}}$ 6938, que instituiu a Política Nacional do Meio Ambiente [Arantes, 1999 e 2002]. Com efeito, esse revigoramento do Ministério Público está estreitamente ligado à normatização dos direitos difusos, coletivos, e individuais indisponíveis e homogêneos, que são aqueles que tratam das questões relacionadas ao meio ambiente, ao patrimônio histórico e cultural, aos direitos do consumidor, à defesa do patrimônio público, ao controle da administração, e aos serviços de relevância pública que envolvem direitos fundamentais como educação, trabalho, saúde, segurança, entre outros. Ao ampliar consideravelmente o seu leque de atuação, o Ministério Público passou a atuar politicamente no debate público nacional. Alguns autores afirmam que os promotores e procuradores fazem concorrência aos partidos 
políticos na sua função de elo de ligação entre as demandas da sociedade civil e o Estado [Kerche, 1999a]. Uma pesquisa realizada em 1996, com 763 integrantes do Ministério Público em sete estados do Brasil, revelou, inclusive, que os promotores e procuradores de justiça são bastante críticos em relação à margem de atuação da sociedade civil para a proteção dos direitos e aos poderes do Estado [Arantes, 1999; Sadek, 1997]. De acordo com os resultados da pesquisa, os membros do Ministério Público acreditam serem eles os responsáveis efetivos pelo alargamento e consolidação dos direitos difusos, coletivos e individuais homogêneos, e não os partidos ou os poderes legislativo e executivo, como seria de se esperar de acordo com o modelo liberal-democrático. Pode-se até afirmar que os integrantes do Ministério Público se consideram como tutores da sociedade brasileira quando se lê, no relatório da pesquisa, que $84 \%$ dos promotores entrevistados concordam com a afirmação de que "a sociedade brasileira é hipossuficiente, isto é, incapaz de defender autonomamente os seus interesses e direitos, e (...), por isso, as instituições da Justiça devem atuar afirmativamente para protegê-la”. Outra afirmação que obteve grande aceitação entre os promotores foi a de que "o Ministério Público deve desempenhar o papel de promoção da conscientização e da responsabilidade da sociedade brasileira”.

Outro estudo, realizado junto a promotores de justiça no interior e na capital do Estado de São Paulo, por meio de uma abordagem qualitativa e antropológica, chegou a um resultado semelhante que identifica o Ministério Público a um “órgão de proteção aos fracos" cuja missão seria assegurar proteção àqueles considerados incapazes e impossibilitados de agir e compreender [Silva, 2001]:

"Nas imagens construídas pelos promotores estudados transparece a convicção de que os interesses da sociedade não são devidamente representados e defendidos na arena política. De acordo com esta visão, os políticos primam 
pela defesa de seus próprios interesses, o poder público não atende a defesa dos cidadãos e a sociedade mostra-se frágil e desorganizada. O Ministério Público viria, pois, preencher um vácuo, fiscalizando políticos e a administração pública e defendendo os interesses da sociedade. Assim, boa parte dos promotores estudados se vêem como agentes de transformação social."

Naturalmente, a sensação de poder transformar a sociedade é incentivada por uma característica do Ministério Público: a independência dos promotores e a ausência de centralização de suas ações. Com efeito, a característica organizacional que faz com que não haja relações de hierarquia no interior do Ministério Público permite aos seus integrantes escolher os casos aos quais vão dedicar atenção. A pesquisa já citada [Sadek, 1997] revela que a independência funcional tem permitido de fato que promotores e procuradores estabeleçam prioridades de atuação em meio ao enorme leque de funções que a instituição acumulou nas últimas décadas. Este fato, aliado ao que alguns autores chamam de "ideologia do voluntarismo político", fez com que um número crescente de promotores tenham por decisão própria passado a dedicar cada vez mais atenção aos direitos difusos e coletivos, em detrimento dos direitos relativos aos crimes contra a pessoa, o tema tradicional do Ministério Público [Sadek, 2000; Arantes, 2002]. Explica-se, assim, o grande interesse dos promotores pela Ação Civil Pública. Numerosos autores apontam para o fato de mais de $90 \%$ das ações civis públicas serem propostas pelo Ministério Público, que tem nessa matéria uma legitimação concorrente, pois, ao contrário da ação penal na qual o Ministério Público tem o monopólio, a promoção da ação civil pública também pode ser feita pela União, estados, municípios, autarquias, empresas públicas, fundações e sociedades de economia mista, sindicatos e associações profissionais, associações de consumidores, associações de moradores, organizações não governamentais [Sadek, 1997; Arantes, 1999 e 2002; Vianna e 
Burgos, 2002]. Pesquisas recentes têm revelado, contudo, mudanças nessa área com a participação crescente de organizações da sociedade civil. Com efeito, se entre 1985 e 1996 apenas 10,3\% das ações civis públicas ajuizadas no Foro Central do Rio de Janeiro tinham por autores associações e ONGs, de 1996 a 2001 nada menos do que 37,7\% das ações civis públicas foram propostas por organizações da sociedade civil, o que se configura numa tendência progressiva [Vianna e Burgos, 2002]. De acordo com estas mesmas pesquisas, os números relativos à participação do Ministério Público passam de $60,9 \%$, no primeiro período, para $42,7 \%$ no segundo. Seja como for, o Ministério Público ainda mantém uma atuação importante na proposição de ações civis públicas. Embora este fato seja destacado com freqüência como uma prova de que os promotores cumprem corretamente o seu dever constitucional de promover e defender a cidadania, há quem o critique. Trata-se do caso de Ada Pelegrini Grinover, por exemplo, para quem há um claro exagero por parte dos promotores neste assunto, fruto de um deslumbramento com relação à titularidade de ações coletivas, e que resulta numa banalização da atuação do Ministério Público nesse tipo de ação [Sadek, 1997].

Uma conseqüência previsível desta realidade é o pequeno espaço que os promotores dedicam ao exercício do controle externo da atividade policial, como previsto pela Constituição. Com efeito, de acordo com a pesquisa já mencionada, apesar de os integrantes do Ministério Público terem uma visão bastante negativa da polícia ${ }^{36}$ eles reconhecem que sua atuação no controle externo da atividade policial deixa muito a desejar. ${ }^{37}$ Principalmente considerando-se o fato de que o bom funcionamento da polícia

\footnotetext{
${ }^{36}$ Para $71 \%$ dos entrevistados a Polícia Civil tem um alto grau de responsabilidade pelo mau funcionamento da Justiça no Brasil; dentre os obstáculos ao bom funcionamento da Justiça no Brasil, 91\% citaram a falta de recursos materiais na Polícia, e 88\% mencionaram o mau desempenho da Polícia; quanto às propostas para melhorar o funcionamento da Justiça, 71\% são favoráveis à transferência dos julgamentos dos crimes cometidos por policiais militares da Justiça Militar para a Justiça Comum [Sadek, 1997].

${ }^{37}$ Apenas 29\% dos entrevistados avalia como positiva a atuação do Ministério Público Estadual no controle externo da atividade policial através de medidas administrativas e judiciais, enquanto somente
} 
é fundamental para que o Ministério Público possa desempenhar corretamente as suas funções, como lembra oportunamente Grinover, fazendo eco à manifestação já citada de Hélio Bicudo [Sadek, 1997]:

"Então, me desculpem, mas acho que ao invés de tocar $90 \%$ das ações civis públicas, o Ministério Público poderia abrir-se mais, para até orientar a sociedade a fazê-lo, e concentrar-se realmente naquilo que hoje é doloroso, naquilo que hoje é revoltante, que é a maneira pela qual se chega à impunidade, exatamente por força de falhas nas investigações."

Os números apresentados a seguir mostram que apenas $16,15 \%$ dos boletins de ocorrência lavrados pela polícia paulista em 1999 geraram inquéritos policiais, e que uma parcela ainda menor $(4,83 \%)$ foi denunciada pelo Ministério Público, sendo que $2,31 \%$ deles correspondem a denúncias em flagrante, para as quais o trabalho investigativo que antecede a denúncia é praticamente nulo [Instituto Cidadania, 2002]:

\section{Denúncias apresentadas pelo Ministério Público Paulista em 1999}

\begin{tabular}{|c|c|c|c|c|}
\hline $\begin{array}{c}1999 \\
\mathrm{SP}\end{array}$ & $\begin{array}{c}\text { Boletins de } \\
\text { ocorrência }\end{array}$ & $\begin{array}{c}\text { Inquéritos } \\
\text { policiais }\end{array}$ & $\begin{array}{c}\text { Denúncias } \\
\text { pelo MP }\end{array}$ & $\begin{array}{c}\text { Denúncias } \\
\text { com flagrante }\end{array}$ \\
\hline $\mathrm{N}^{\mathrm{o}}$ & 523.396 & 84.519 & 25.301 & 12.102 \\
\hline$\%$ & 100 & 16,15 & 4,83 & 2,31 \\
\hline
\end{tabular}

Fonte: Instituto Cidadania

Para a correta apreciação destes dados, é preciso lembrar que apenas um terço das ocorrências criminosas, aproximadamente, são comunicadas à polícia que, em várias ocasiões, desestimula o cidadão que pretende fazer uma denúncia com o objetivo de diminuir o número de inquéritos lavrados [Kant de Lima, 1995]:

$34 \%$ afirmou ter incluído o controle externo da polícia entre as suas prioridades nos últimos dois anos antes da realização da pesquisa [Sadek, 1997]. 
"O registro da ocorrência dependia muito da vontade da autoridade policial, vontade nem sempre exercida em estrita obediência à lei. Isso é difícil de negar, por exemplo, quando a polícia convence a vítima de não registrar o delito como ocorrência criminal. Os policiais alegavam que com essa atitude estavam "poupando papel e trabalho", mas pareciam, na realidade, bem mais preocupados em poder apresentar uma baixa estatística de casos não resolvidos.” O diagnóstico sobre a atuação do Ministério Público na persecução penal incluído no Projeto Segurança Pública para o Brasil [Instituto Cidadania, 2002], elaborado pelo atual governo federal, chama ainda a atenção para algumas práticas que contribuem para esse quadro de ineficiência investigatória:

“O Ministério Público não toma conhecimento dos registros de ocorrências de crime, deixando de exercer o controle externo das investigações policiais; os delegados de polícia não presidem os inquéritos policiais, que, em regra, são realizados pelos escrivães de polícia; o Ministério Público e o Poder Judiciário não estabelecem prazos para a conclusão dos inquéritos; os indiciamentos não são submetidos à apreciação do Ministério Público. Como principal conseqüência da ineficiência estrutural do inquérito policial, o Ministério Público deixa de obter os elementos necessários para ajuizar a ação penal pública, prejudicando todo o sistema de persecução penal”.

A essas atividades proativas, de acompanhamento e avaliação da atividade policial que resulta na produção do inquérito, deve-se acrescentar funções reativas de formulação e encaminhamento judicial de denúncias, assim como de fiscalização da maneira como o público é abordado na rua pelas rondas policiais e tratado nas delegacias e nas celas localizadas em distritos policiais [Lemgruber et alii, 2003]. Na prática, contudo, este grande raio de atuação é limitado por dificuldades das mais 
diversas ordens. Algumas pesquisas já realizadas permitem destacar a experiência de alguns ministérios públicos estaduais como os de Minas Gerais, Bahia e Goiás que parecem ter um engajamento mais atuante na defesa dos cidadãos contra abusos das autoridades policiais, enquanto outros têm tido uma atuação insatisfatória [Macaulay, 2002; Sanches Filho, 2000]. O resultado principal que estas pesquisas mostram, contudo, é a grande disparidade entre os diferentes ministérios públicos estaduais, cuja organização e prioridades variam consideravelmente.

No que diz respeito ao efetivo exercício do controle externo da atividade policial pelas promotorias pode-se considerar três ordens de obstáculos. Em primeiro lugar, é preciso ressaltar a dificuldade de se promover qualquer política institucional no interior do Ministério Público, como uma conseqüência da característica de independência funcional de seus membros [Kerche, 1999B]. Com efeito, ações articuladas seriam mais eficientes para o controle da atividade policial. Os grupos de atuação especial, que dão bons resultados em algumas áreas como o combate ao crime organizado e à corrupção [Arantes, 2002], não fornecem uma institucionalização tão sólida quanto a que poderia ser alcançada pelo instrumento da regulamentação legal. ${ }^{38}$ Neste sentido, o diagnóstico do Projeto Segurança Pública para o Brasil, já mencionado, é de que o controle externo da atividade policial não está suficientemente regulamentado pela Lei Complementar nº75, de 1993, que dispõe sobre a organização e as atribuições do Ministério Público da União e que tem sido utilizado de forma subsidiária pelas promotorias estaduais. Assim: "O controle externo da atividade policial somente será eficaz quando o Ministério Público o exercer por meio do estabelecimento, em lei, de diretrizes gerais e específicas para a condução dos trabalhos e das atividades de ambas as polícias, notadamente os da civil. As diretrizes gerais definirão os grandes

\footnotetext{
${ }^{38}$ Veja-se, por exemplo, o Gecep (Grupo de Atuação Especial de Controle Externo da Atividade Policial), formado em 2003 no Ministério Público paulista, e que encontra grande resistência entre os delegados de polícia.
} 
vetores da instrução preliminar, de acordo com os parâmetros de política criminal traçados pelo Ministério Público”.

Por enquanto, muitos Ministérios Públicos estaduais se baseiam nas diretrizes das Leis Orgânicas Estaduais, embora algumas “células” de promotores ativistas como, por exemplo, as Promotorias de Investigação Penal e a Promotoria Central de Inquérito, instaladas no Rio de Janeiro, possam oferecer resultados mais eficazes [Macaulay, 2002]. A importância das leis para o estabelecimento de políticas institucionais de controle externo da polícia pelo Ministério Público é decisiva, pois muitos delegados de polícia se aproveitam da ausência delas para deslegitimar a atuação dos promotores na supervisão das atividades policiais, como mostra o seguinte depoimento de um delegado de polícia da Bahia [Sanches Filho, 2000]:

"O controle externo é aquele da atividade policial e não sobre a autoridade policial... é preciso que se faça essa diferença... mas, ainda não foi regulamentado. Mesmo assim, alguns promotores têm feito e nós, como autoridade policial que estamos no mesmo patamar da intelectualidade dos promotores, atendemos bem e oferecemos os dados necessários".

Para avaliar o quanto de ironia e cinismo estão contidos nesta opinião, é preciso levar em conta a pressão exercida pela polícia civil para impedir que o texto da Constituição de 1988 fosse aprovado de maneira a permitir a fiscalização da polícia pelo Ministério Público. O testemunho do deputado federal constituinte Ibsen Pinheiro (PMDB/RS) é bastante revelador a este respeito:

"Não foi fácil chegar ao novo perfil da instituição. Eu sei porque estava na Constituinte e, designado pelo líder Mário Covas, coordenei a elaboração do texto dos artigos 127, 128 e 129 que compõem a seção do Ministério Público na Constituição Federal, conduzindo, também, a pesada negociação que a precedeu, 
não apenas entre as lideranças políticas, mas muito mais com as corporações interessadas, especialmente as polícias civil e militar, a magistratura e a advocacia. (...) Logo, o perfil do Ministério Público que aí está não é casual, nem acidental, mas produto de muita reflexão, muito entendimento, e algumas concessões de partes a partes (daí a diferença no mecanismo de provimento do cargo de Procurador Geral da União e nos estados, assim como a expressão controle externo da atividade policial)." [Pinheiro, 2000]

Cerca de dez anos depois, em 1999, a deputada federal Zulaiê Cobra (PSDB/SP) apresentou, por ocasião da "Reforma do Judiciário e do Ministério Público", então em tramitação no congresso nacional, uma proposta de retirar a expressão "controle externo" do artigo 129, com o objetivo de fixar os limites da fiscalização da atividade policial pelo Ministério Público. [Guimarães, 2002] Na exposição de motivos da sua proposta, que acabou sendo rejeitada, a deputada argumentava que:

"Na linha das considerações feitas pelo ilustre deputado José Roberto Batochio sobre a impropriedade da expressão controle externo na redação do inciso VII do art. 129, alteramos o texto em questão para torná-lo mais claro, fixando os limites da fiscalização da atividade policial pelo Ministério Público.” Torna-se oportuno lembrar que alguns autores identificam na pressão da polícia contra o mecanismo do controle externo a causa da demora da regulamentação do art.129 por lei complementar nos estados. [Guimarães, 2002] A Associação dos Delegados de Polícia do Brasil (ADEPOL) chegou até a ingressar com ações diretas de inconstitucionalidade, no STF, contra os estados do Rio de Janeiro e de São Paulo, cujos ministérios públicos estariam se "intrometendo em atividades internas da polícia".

Mais recentemente, contudo, uma antiga reivindicação de Luiz Antônio Marrey, ex-Procurador Geral de Justiça do Estado de São Paulo de 1996 a 2000 e de 2002 a 
2004, foi colocada em prática com a implantação do Grupo de Atuação Especial de Controle Externo da Atividade Policial (GECEP), criado oficialmente em 29 de agosto de 2003. De acordo com o promotor de justiça Márcio Christino ${ }^{39}$, integrante do GECEP, a atuação dos seis integrantes do grupo consiste em:

- $\quad$ fiscalizar as prisões temporárias, quando pedem em separado exame de corpo e delito e verificam se o acusado sofreu algum tipo de violência por parte da polícia;

- $\quad$ acompanhar os procedimentos nos quais há necessidade de intervenção judicial, como a quebra de sigilo telefônico, bancário ou fiscal; instaurar um processo próprio de apuração.

Além disso, os promotores do GECEP visitam de um a dois distritos policiais por semana para verificar as condições da carceragem, vistoriar o livro de ocorrências, controlar os objetos apreendidos e verificar se os registros das armas apreendidas estão em conformidade com as regras. Durante essas visitas os presos são ouvidos e, no caso de alguma irregularidade mais grave ser constatada, os promotores têm autoridade para fazer uma representação junto ao juiz corregedor para a remoção do preso. Um problema que dificulta muito o trabalho dos promotores, ainda segundo o mesmo depoimento, é a falta de estrutura para realizar investigações.

O segundo obstáculo enfrentado pelo Ministério Público no controle da polícia consiste, portanto, na extrema relutância demonstrada por parte dos delegados de polícia em colaborar com os promotores de justiça que, segundo eles, vêm interferir e atrapalhar nas suas atividades. Uma pesquisa detalhada realizada ao longo dos anos de 2001 e 2002 junto a 1228 delegados de polícia de nove estados da federação (Amapá, Bahia, Distrito Federal, Goiás, Pernambuco, Paraná, Rio de Janeiro, Rio Grande do Sul,

\footnotetext{
${ }^{39}$ Depoimento dado ao autor em dezembro de 2004.
} 
São Paulo) ${ }^{40}$ é bastante reveladora no que diz respeito ao grau de animosidade existente entre os delegados e os promotores de justiça. A despeito de várias iniciativas por parte do governo federal no sentido de incentivar uma maior cooperação entre os departamentos policiais e os ministérios públicos estaduais [Arantes e Cunha, 2003], os delegados de polícia são bem céticos quanto às boas intenções dos promotores de justiça [Cavalcanti, 2003]. Entre estes dois grupos há uma verdadeira rivalidade, a julgar pelos comentários dos delegados de polícia que criticam sobretudo a interferência dos promotores na investigação criminal e a diferença de tratamento que as duas carreiras dispensam a seus integrantes, com grande desvantagens para os delegados. Com a palavra, os delegados:

"Os promotores de justiça, usurpando da função, vêm desenvolvendo o trabalho de investigação policial” (Rio Grande do Sul)

“O Ministério Público passou a querer controlar todo o trâmite e serviços de delegacia, em alguns casos, querendo até mandar no delegado” (Paraná)

“O sistema de aplicação da justiça, sobretudo a penal, não pode dispensar ao delegado de polícia outro tratamento senão aquele semelhante a juízes e promotores, notadamente no que se refere a salário, prestígio e posição social" (Bahia)

"Para a polícia, nada, para o Ministério Público e o Judiciário, imunidades e privilégios" (Rio de Janeiro)

Quanto ao tratamento quantitativo dos questionários respondidos pelos delegados, a pesquisa mostra que $61 \%$ dos entrevistados consideram a interferência do Ministério Público na atividade policial como um obstáculo ao bom funcionamento da polícia civil. Quando instados a qualificar propostas para melhorar o funcionamento da

\footnotetext{
40 Trata-se da pesquisa "Quem são e o que pensam os delegados de polícia”, realizada pelo Idesp, com apoio da Fundação Ford e da Fapesp. [Sadek, 2003]
} 
polícia civil, a metade dos entrevistados considera muito importante ou importante a criação de um órgão especial de controle externo da Polícia, mas apenas $18 \%$ aceitam que esse controle externo seja exercido pelo Ministério Público. Este dado contrasta com a resposta de $70 \%$ dos delegados que concordam totalmente ou em termos com a proposta de criação ou fortalecimento da Ouvidoria de Polícia para melhorar a segurança pública. Por fim, dentre as propostas para melhorar o desempenho do sistema penal e diminuir a impunidade e a criminalidade, mais de $90 \%$ dos delegados discordam tanto da criação de grupos de investigação dentro do Ministério Público quanto da direção dos trabalhos de investigação policial pelo Ministério Público.

Esta rivalidade entre os delegados de polícia e os promotores públicos está também na origem do terceiro obstáculo ao controle da atividade policial pelo Ministério Público. Com efeito, os promotores sabem muito bem que o controle externo não é bem-vindo nas delegacias. Da mesma forma como sabem que para o exercício satisfatório da sua função principal, que é a promoção da ação penal, eles dependem de um trabalho investigatório prévio da polícia. Não seria racional, portanto, dificultar, ou até inviabilizar, o desempenho de suas obrigações profissionais devido a um controle excessivo das atividades policiais, como mostra o seguinte depoimento [Debert, 2000]:

"O que normalmente acontece é que o promotor, por uma questão de solidariedade ou de comodismo, assina embaixo o que a polícia encaminha para ele, esse é que é o grande perigo; eles não arriscam o cargo deles; pisam na bola; empurram os casos com a barriga; existe muita politicagem."

Em outras palavras, o Ministério Público é também um usuário dos serviços da polícia, pois é o destinatário dos inquéritos policiais. Vários episódios já mostraram que há integrantes do Ministério Público que não hesitam em se colocar no lugar do cidadão e defender os seus direitos e interesses frente às arbitrariedades e ilegalidades cometidas 
por membros da força policial. Nunca é demais lembrar mais uma vez o exemplo de Hélio Bicudo.

Na questão do controle externo, contudo, o fundamental "é saber se a instituição está cumprindo bem a finalidade a que se destina, e aí só quem pode dizer isso é o destinatário dos serviços", como diz João Piquet Carneiro [Sadek, 1997]. Longe de concluir, portanto, que o Ministério Público é mais eficiente do que as Ouvidorias de Polícia, ou o contrário, para o exercício do controle externo da atividade policial, afirmamos a necessidade de manter as duas formas de supervisão. O Ministério Público, como usuário dos inquéritos policiais está mais bem preparado para verificar a idoneidade das investigações, enquanto que o cidadão comum, como usuário dos serviços policiais de proteção da paz e garantia da segurança pública, está mais bem posicionado para avaliar adequadamente a prestação destes serviços na comunidade. Afinal de contas, somente o cidadão comum pode dizer como é abordado pelos policiais nas ruas e de que maneira é recebido nas delegacias quando vai fazer uma queixa.

Um fato relevante parece-nos ser a relativa indiferença com que o Ministério Público considera as ouvidorias da polícia. Quando indagado a este respeito, o já citado promotor de justiça paulista Márcio Christino afirmou que não mantém qualquer tipo de contato regular com a ouvidoria da polícia de São Paulo. "De uma maneira geral, o que se observa é que quando as pessoas vêm aqui, elas já estiveram na corregedoria, no juiz, na ouvidoria, de modo que não é necessário comunicar à ouvidoria." Do lado das ouvidorias, este mesmo sensação de indiferença é sentida, como mostra o depoimento da ouvidora da polícia do Pará, Rosa Marga Rothe, por ocasião da sua participação na $1^{a}$ Conferência Internacional Sobre Controle Externo da Polícia Brasil-Canadá, realizada em 1999, em São Paulo, por iniciativa do Fórum Nacional de Ouvidores de Polícia e da Ouvidoria da Polícia de São Paulo: 
“O Ministério Público tem sido freqüentemente acionado pela Ouvidoria que passou a encaminhar denunciantes, juntamente com as denúncias nas quais há indícios de crimes. Ao sentirem-se incomodados pela Ouvidoria, os membros daquela instituição têm reagido diversamente. Alguns promotores realmente somam forças e não têm se esquivado diante daquele acréscimo de trabalho. Outros "empurram com a barriga", devolvendo para a polícia o que deveria ser encaminhado ao Poder Judiciário, facilitando assim a protelação e o acobertamento. Existem aqueles promotores que reconhecem a Ouvidoria como uma parceira útil e por isso oferecem e solicitam colaboração. Outros, embora enviem denúncias e termos de declaração, deixam de responsabilizar autoridades policiais criminosas. Pelas dificuldades observadas, parece-nos haver no Ministério Público a predominância daqueles que não querem ser incomodados por um órgão ao qual não estão hierarquicamente obrigados a prestar colaboração ou informações. Várias vezes, reclamamos a ausência do retorno das medidas adotadas, para informação aos denunciantes e à sociedade em geral." [Rothe, 2000]

Uma pesquisa recente ilustra bem este ponto ao analisar a implementação da Lei Federal $\mathrm{n}^{\circ}$ 9.299-96, que transfere para a Justiça Comum os casos de homicídios dolosos praticados por policiais militares no exercício de suas funções, no Estado de São Paulo. [Affonso, 2004] A partir da análise dos dados de homicídios dolosos de 271 civis em 229 ocorrências, que tiveram o envolvimento de 489 policiais militares, registrados na Ouvidoria da Polícia do Estado de São Paulo, entre os anos de 1996 e 1998, verificou-se que o Ministério Público tende a acompanhar e confirmar o resultado de processo administrativo realizado pela polícia. Nos casos de "resistência seguida de morte", o Ministério Público não apenas segue o resultado do processo administrativo, 
como declara extinta a punibilidade do réu. Note-se que a extinção da punibilidade é aplicada somente ao crime cometido pela vítima da ação policial, ignorando que o processo se refere ao homicídio cometido pelo policial e não ao crime cometido pela vítima da ação policial. [Affonso, 2004]

Por fim, vale a pena prestar atenção às palavras proferidas por Luiz Antônio Guimarães Marrey, ex-Procurador Geral de Justiça do Estado de São Paulo, na $1^{a}$ Conferência Internacional Sobre Controle Externo da Polícia Brasil - Canadá, realizada em novembro de 1999, pois elas servem também para as ouvidorias de polícia ainda instaladas de maneira precária no Brasil:

"O início dessa atividade que ainda é bastante imperfeita, mas é melhor tê-la imperfeita do que não tê-la. A justificativa da plena eficácia como condição para o exercício é uma justificativa paralisante, se nós chegarmos à conclusão ou exercemos essa atividade de maneira totalmente eficaz ou não vamos exercer, isto é, o álibi para nada se fazer e mesmo para a discussão travada internamente no Ministério Público, em relação a essa atividade, alguns colegas diziam mas por vezes nas visitas a unidades policiais, no exame de livros policiais, no exame das relações de presos, enfim, há um risco profissional que todos vamos sempre correr, mas admitir-se ou não se fazer essa atividade sobre esse pretexto significa chancelar a paralisia e omissão.” [Mariano, 2000] 


\section{Ouvidorias de Polícia em atividade no Brasil}

\subsection{Descrição das Ouvidorias existentes}

Há atualmente - segundo semestre de 2005 - catorze ouvidorias de polícia em atividade no Brasil, como pode ser verificado no quadro a seguir.

\begin{tabular}{|l|l|}
\hline Estado & Nome do órgão \\
\hline Bahia & Ouvidoria da Secretaria de Segurança Pública \\
\hline Ceará & Ouvidoria da Secretaria da Segurança Pública e Defesa Social \\
\hline Espírito Santo & Ouvidoria-Geral da Segurança Pública e Defesa Social \\
\hline Goiás & Ouvidoria-Geral de Polícia \\
\hline Minas Gerais & Ouvidoria da Polícia \\
\hline Mato Grosso & Ouvidoria de Polícia \\
\hline Pará & Ouvidoria do Sistema de Segurança Pública \\
\hline Paraná & Ouvidoria da Polícia \\
\hline Pernambuco & Ouvidoria da Secretaria de Defesa Social \\
\hline Rio de Janeiro & Ouvidoria da Polícia \\
\hline Rio Grande do Norte & Ouvidoria da Defesa Social \\
\hline Rio Grande do Sul & Ouvidoria da Justiça e da Segurança \\
\hline Santa Catarina & Ouvidoria da Secretaria de Segurança Pública e Defesa do Cidadão \\
\hline São Paulo & Ouvidoria da Polícia \\
\hline
\end{tabular}

Mais três estados devem implantar ouvidorias de polícia em breve: Amapá, Paraíba e Sergipe. Antes de prosseguir na análise das ouvidorias, elaboramos um breve histórico de cada uma delas. Faz-se necessário salientar, contudo, que trata-se de experiências diferentes e que não possuímos a mesma quantidade de informações sobre todas as ouvidorias. 
Bahia

A Ouvidoria da Secretaria de Segurança Pública da Bahia foi criada pelo decreto $n^{\circ} 7.623$ de 25 de junho de 1999 e passou a funcionar efetivamente a partir da nomeação de Maria da Purificação de Lira para o cargo de ouvidora, função que ela ocupa desde então. Delegada da Polícia Civil da Bahia, a ouvidora é membro atuante da Associação dos Delegados da Bahia (ADPEB), da qual foi Segunda Secretária no período 19811983, na gestão União e Progresso, Primeira Secretária no período 1997-1999, na gestão Renovação e Trabalho, e Conselheira Suplente no período 1999-2001 na gestão Realização. ${ }^{41} \mathrm{O}$ ouvidor adjunto, Carlos Raimundo Dória Amaral, é Delegado Chefe da Polícia Civil de Eunápolis. ${ }^{42}$ Cinco anos após a sua instalação, a ouvidoria de polícia da Bahia conta com 11 funcionários, incluída a ouvidora, e produz um relatório de atividades semestral que é encaminhado ao secretário da segurança pública do estado e à Secretaria Nacional de Segurança Pública (SENASP), no Ministério da Justiça, em Brasília. Estes relatórios, contudo, não são abertos ao público.

\section{Ceará}

A Ouvidoria da Secretaria da Segurança Pública e Defesa Social do Estado do Ceará é ligada à Secretaria da Ouvidoria-Geral e do Meio Ambiente (SOMA), criada pela lei estadual $\mathrm{n}^{\mathrm{o}} 13.093$, de 8 de janeiro de 2001. Os trabalhos foram iniciados com a nomeação, através da portaria $n^{0}$ 047/2003-GS, de Franklin de Freitas Lopes como primeiro ouvidor. Trata-se de um coronel do corpo de bombeiros militar, formado em direito, sociologia e educação física, que é também coordenador estadual dos Conselhos Comunitários de Defesa Social. De acordo com o ouvidor ${ }^{43}$, as instalações da ouvidoria são satisfatórias e a equipe de trabalho é adequada, sendo composta por 13 funcionários

\footnotetext{
${ }^{41}$ De acordo com o as informações do site da ADPEB na internet: http://www.adpeb.org.br/diretorias.asp

${ }^{42}$ Ao que consta em http://www.bahia.ba.gov.br/ssp/delegacias interior.htm

${ }^{43}$ Depoimento dado ao autor a 9 de junho de 2005.
} 
cedidos pela Diretoria da Defesa Social da Secretaria de Segurança Pública e Defesa Social do Ceará, mais o ouvidor adjunto, o policial civil Marcel Trevisan, e o próprio ouvidor. Além dos relatórios semanais, a ouvidoria elabora um relatório anual que pode ser obtido sob solicitação. No momento, a equipe da ouvidoria tem dois desafios pela frente, segundo o depoimento do ouvidor: o fortalecimento das atividades em todo o estado e a publicação de um decreto-lei com o objetivo de consolidar a ouvidoria.

\section{Espírito Santo}

A instalação da Ouvidoria-Geral da Segurança Pública e Defesa Social do Espírito Santo, a partir de junho de 2005, representa a vitória da persistência dos defensores dos direitos humanos capixabas. Instituída originalmente em 1998 por uma legislação bastante avançada ${ }^{44}$ e que a tornaria a quarta ouvidoria de polícia a funcionar no país, ela não chegou a ser instalada. Curiosamente, a lei n ${ }^{\circ} 5649 / 98$ de 14 de maio de 1998, que deveria instituir a Ouvidoria da Polícia do Estado do Espírito Santo foi sancionada pelo então presidente da assembléia legislativa do estado, deputado José Carlos Gratz, cuja reeleição em 2002 foi cassada pelo Tribunal Regional Eleitoral do Espírito Santo, sob acusação de abuso do poder econômico e compra de votos. ${ }^{45}$

Durante todo o mandato de José Ignácio Ferreira (PSDB), que governou o estado de 1999 a 2002 e foi denunciado no STJ junto com José Carlos Gratz, as entidades de defesa dos direitos humanos lutaram em vão para que a ouvidoria saísse do papel. Somente a partir da eleição do governador Paulo Hartung (PSB) foram criadas as

\footnotetext{
${ }^{44}$ A lei $\mathrm{n}^{\mathrm{o}}$ 5649/98, de 14 de maio de 1998, inclúa um mandato de dois anos com possibilidade de uma recondução para o ouvidor, que seria nomeado pelo governador a partir de uma lista tríplice elaborada pelo Conselho Estadual de Direitos Humanos do Espírito Santo.

${ }^{45}$ Gratz foi também acusado pelo Ministério Público Federal de ser um dos líderes do crime organizado no estado e foi apontado pela Comissão Parlamentar de Inquérito do Narcotráfico como um dos envolvidos em crime de lavagem de dinheiro, contrabando e homicídio. Denunciado pelo ministério público no final de 2004, Gratz foi condenado em janeiro de 2005 e se encontra atualmente preso.
} 
condições para que a ouvidoria da polícia pudesse ser implantada. Para isso, contudo, foi preciso aprovar uma nova legislação para reestruturar a Secretaria de Estado da Segurança Pública (SESP) na forma da lei complementar nº 297 de 27 de julho de 2004, que prevê a ouvidoria-geral da defesa social, cujo regimento foi regulamentado pelo decreto $\mathrm{n}^{\mathrm{o}} 1473-\mathrm{R}$ de 28 de março de 2005 . De acordo com as novas regras, o ouvidor é nomeado pelo governador a partir da indicação do secretário da segurança e não tem mais mandato. Naturalmente, houve uma certa dificuldade em encontrar alguém disposto a assumir o cargo de ouvidor no estado, com um problema sério de crime organizado, e a tarefa de implantar a ouvidoria da polícia no estado foi confiada a um advogado com longa militância nos direitos humanos e animado com o desafio que tem pela frente ${ }^{46}$. Com efeito, Sandro Chamon do Carmo já foi presidente do Conselho Estadual de Direitos Humanos do Espírito Santo, integrou a Comissão Justiça e Paz no estado de 1979 a 1987, foi vice-presidente da OAB/ES, e Secretário de Cidadania e Direitos Humanos de Vila Velha de 2001 a 2004.

\section{Goiás}

A Ouvidoria-Geral de Polícia do Estado de Goiás foi criada pela lei n ${ }^{\circ} 14.383$ de 31 de dezembro de 2002 que modificou a organização administrativa do poder executivo. A ouvidoria foi efetivamente instalada a 8 de setembro de 2003, com a nomeação de Paulo Célio de Souza Leal, um funcionário público aposentado pertencente ao quadro da Presidência da República que já foi responsável pelo Departamento de Articulação das Ações Policiais Integradas na Secretaria Nacional de Segurança Pública do Ministério da Justiça. O cargo de ouvidor é de livre escolha do governador e o quadro de funcionários ainda está incompleto. Por enquanto há, além do

\footnotetext{
46 “A esta altura da vida não tenho mais medo de nada, pois sou do partido da pessoa humana", afirmou o ouvidor em depoimento dado ao autor a $1^{\circ}$ de junho de 2005.
} 
ouvidor, um gerente operacional responsável pela parte administrativa, um gerente de atendimento ao cidadão, dois assessores de nível superior, formados em direito, quatro estagiários que fazem as vezes de atendentes e uma secretária junto ao ouvidor. A ouvidoria realiza um relatório de atividades anual que é encaminhado ao governador, ao secretário da segurança pública e ao ministério da justiça, em Brasília.

\section{Minas Gerais}

A Ouvidoria da Polícia do Estado de Minas Gerais foi criada pela lei $\mathrm{n}^{\circ} 12.622$ de 25 de setembro de 1997, de acordo com um projeto de lei apresentado pelo deputado Durval Ângelo (PT), que foi aprovado em decorrência das condições políticas criadas pela CPI do Sistema Penitenciário da Assembléia Legislativa, em 1997. O ouvidor é nomeado pelo governador a partir de uma lista tríplice, elaborada pelo Conselho Estadual de Defesa dos Direitos Humanos (CONEDH), para um mandato de dois anos que pode ser reconduzido apenas uma única vez. Com a escolha do advogado criminalista, ativista de direitos humanos e ex-preso político, José Roberto Gonçalves de Rezende, surgiu um impasse que durou quase um ano porque as forças conservadoras não aceitavam a sua indicação. Foi necessário alterar a lei original para proibir a possibilidade de recondução para o primeiro ouvidor, como explicita a lei 12.968 de 27 de julho de 1998. A ouvidoria pôde então ser inaugurada a 8 de setembro de 1998, com a posse de José Roberto Gonçalves de Rezende ${ }^{47}$, que faleceu em agosto de 2000, sendo substituído pela procuradora do estado aposentada e ex-presidente do CONEDH Maria do Rosário Caiafa Farias. Em novembro de 2002, tomou posse como ouvidor o psicólogo e ex-secretário-adjunto de direitos humanos do estado José Francisco da

\footnotetext{
${ }^{47}$ Uma curiosidade: em entrevista à Revista do Legislativo, publicada pela Assembléia Legislativa do Estado de Minas Gerais, o ouvidor contou que, um minuto após o término da solenidade de posse, um morador da periferia de Belo Horizonte o procurou com uma queixa de violência policial. [Rezende, 1998]
} 
Silva, que está atualmente no seu segundo mandato. Tendo funcionado de maneira precária até 2003, por falta de recursos materiais e humanos ${ }^{48}$, a ouvidoria conta atualmente com uma equipe de 32 pessoas e um apoio substancial da SENASP e estabeleceu acordos de cooperação e pesquisa com o Centro de Estudos de Criminalidade e Segurança Pública (CRISP), do Departamento de Sociologia e Antropologia da UFMG. O convênio com a universidade permite a realização de várias pesquisas e a sua publicação, assim como a dos livros $A$ Ouvidoria agora vai falar e $A$ Ouvidoria da Polícia de Minas Gerais mostra o que faz, editados em 2003 e 2004, respectivamente. O primeiro livro contém também o relatório anual de 2003. Os relatórios de atividades são elaborados trimestralmente e podem ser encontrados na página que a ouvidoria mantém na internet. A partir do ano passado a ouvidoria da polícia passou a fazer parte da Ouvidoria-Geral do Estado de Minas Gerais, de acordo com a lei 15.298 de 6 de agosto de 2004, mas o essencial da lei original foi mantido. No momento encontra-se em fase adiantada a descentralização da ouvidoria em nove municípios do interior do estado.

\section{Mato Grosso}

Instituída pela lei $\mathrm{n}^{\mathrm{o}} 7.286$ de 23 de maio de 2000 , posteriormente modificada pela lei $n^{0} 7.885$ de 6 de janeiro 2003, a Ouvidoria de Polícia de Mato Grosso só foi instalada a 18 de julho de 2003, com a nomeação do seu primeiro ouvidor, o advogado criminal e professor da Faculdade de Direito da Universidade Federal do Mato Grosso (UFMT) Auremácio José Tenório de Carvalho. Nomeado pelo governador para um

\footnotetext{
${ }^{48}$ Em um texto produzido para o portal www.dhnet.org.br, por exemplo, a ouvidora Maria do Rosário Caiafa Farias queixava-se de que "das cinco assessorias, apenas uma se encontra em funcionamento, exercida por um delegado de polícia. Vale dizer que, no espaço responsável pelo monitoramento das denúncias sobre policiais que cometem crimes, não existe um único advogado. Sendo assim, a Ouvidoria tem hoje um acúmulo inacreditável de processos (cerca de 600) gerando, em cada um de nós, uma tensão insuportável."
} 
mandato de dois anos a partir de uma lista tríplice elaborada pelo Conselho Estadual de Defesa dos Direitos da Pessoa Humana (CEDDPH/MT), o ouvidor tem um longo envolvimento com os movimentos de defesa dos direitos humanos do estado e foi ouvidor geral da UFMT de 2000 a 2003 . Recém instalada, a ouvidoria tem funcionado de maneira precária. Como não tem sede própria, a ouvidoria já funcionou em uma sala emprestada da Corregedoria da Polícia Civil, no CEDDPH e na sala do professor na UFMT. Até completar um ano de existência, o salário da estagiária de direito e única funcionária além do ouvidor era pago pelo próprio ouvidor, que colocou o seu telefone celular à disposição para o recebimento de denúncias. O ouvidor tem enfrentado essas limitações com parcerias com a sociedade civil organizada e com um convênio assinado entre o governo federal e o governo do Mato Grosso para aparelhar materialmente a ouvidoria.

Pará

A Ouvidoria do Sistema de Segurança Pública do Pará, instituída pela lei 5.944 de 6 de fevereiro de 1996, iniciou suas atividades em junho de 1997, com a nomeação de Rosa Marga Rothe. Formada em teologia, Rosa é pastora da Igreja Evangélica de Confissão Luterana, foi pioneira do movimento ecumênico do Pará e tem uma longa experiência como educadora popular, tendo sido fundadora do Instituto Universidade Popular. Conhecida militante de direitos humanos, ela foi presidente da Sociedade Paraense de Defesa dos Direitos Humanos, onde realizou ações em prol da melhoria da segurança pública. A sua nomeação já estava decidida em novembro de 1996, mas foi preciso esperar pela conclusão do seu processo de naturalização para que pudesse assumir o cargo de ouvidora. No Pará, a lei determina que o ouvidor da polícia é nomeado a partir da indicação do Conselho Estadual de Segurança Pública (CONSEP), 
integrado por representantes do governo e da sociedade civil, por um mandato de dois anos que pode ser renovado indefinidamente. Rosa Marga Rothe foi ouvidora por quatro mandatos consecutivos, até ser substituída, em 28 de agosto de 2005, pelo delegado de polícia aposentado, que já foi Corregedor Geral de Polícia, Delegado Geral de Polícia e Secretário de Segurança Pública do Pará, Lélio Railson Dias de Alcantara. Trata-se, portanto, do recorde de permanência à frente de uma ouvidoria de polícia no país. A possibilidade de ser reconduzida mais uma vez não assustava a ouvidora quando conversamos com ela, um pouco antes da sua substituição: "Um dia desses tive um encontro com a ouvidora da polícia da cidade de San Diego, na Califórnia, e ela me disse que só viu resultados após dez anos de trabalho, de modo que fiquei mais tranqüila, ainda mais que lá são relatados apenas 38 conflitos armados por ano", afirma Rosa. ${ }^{49}$ A perseverança foi fundamental para que a ouvidoria do Pará, a segunda a ser criada no país, se tornasse uma realidade: "Foi só criado o cargo de ouvidor, e nada mais; quando cheguei não tinha nada, nem mesa, nem cadeiras; tivemos que conseguir tudo aos poucos e a muito custo", de acordo com a ouvidora. Com efeito, após sua nomeação, foram necessários seis meses para que fossem criadas condições mínimas de trabalho e a inauguração aconteceu a 10 de dezembro de 1997, já com quase 100 denúncias em andamento. Hoje a ouvidoria conta com nove salas e 23 funcionários que se revezam em dois turnos de seis horas consecutivas, das 8:00 às 18:00 horas. Das 12:00 às 14:00 horas as duas equipes do turno da manhã e do turno da tarde se encontram, quando passam o trabalho uma para a outra. Na prática, portanto, a ouvidora pode contar apenas com metade do pessoal. Os funcionários são requisitados de outros órgãos estaduais e os salários são muito ruins, o que tem conseqüências quanto à eficiência de trabalho. Os recursos orçamentários dependem da Secretaria de Segurança

\footnotetext{
${ }^{49}$ Depoimento dado ao autor a 13 de junho de 2005.
} 
Pública que, nos últimos dois anos deixou de dar o apoio que a ouvidoria tinha no governo anterior. Os relatórios de atividades são elaborados anualmente, mas não são muito bem vistos pelos responsáveis pela segurança pública, segundo o depoimento de Rosa Marga Rothe: o relatório de 2003 não foi aprovado, precisou ser reformulado, e o relatório de 2004 ainda estava para ser concluído em junho de 2005. Uma resolução do CONSEP que obriga a polícia a comunicar as mortes à ouvidoria aumentou muito o número de casos a partir de 2000.

\section{Paraná}

A Ouvidoria da Polícia do Estado do Paraná foi criada pelo decreto $\mathrm{n}^{\circ} 2.026$ de 9 de maio de $2000^{50}$, durante o governo de Jaime Lerner (PFL). A ouvidoria foi implantada a 15 de agosto do mesmo ano com a nomeação do delegado de polícia aposentado, e também professor da Universidade Federal do Paraná (UFPR), Almir Chagas Vilela. De acordo com o texto do referido decreto, o ouvidor é nomeado pelo governador para um mandato de um ano, que pode ser renovado uma única vez. Mesmo assim, Almir Chagas Vilela permaneceu no cargo até a posse do novo governador, Roberto Requião (PMDB), a $1^{\circ}$ de janeiro de 2003, quando foi substituído pelo ouvidor atual, Luís Alberto Franco Bordenowski. Escrivão de polícia aposentado há oito anos, fato que, na sua opinião, o legitima para comandar a ouvidoria pois teria perdido todos os vínculos com a nova geração, Bordenowski é, contudo, membro atuante do Sindicato das Classes Policiais Civis no Estado do Paraná (SINCLAPOL). Ele foi, por exemplo, $1^{\mathrm{o}}$ Vice-Presidente do sindicato na gestão da chapa Realização - Promete e Cumpre 2004, junto com Almir Fernandes, $2^{\circ}$ Vice-Presidente, e Marcos Tempel Mesquita, $1^{\circ}$

\footnotetext{
${ }^{50}$ Apenas dois meses depois, houve uma pequena modificação introduzida pelo decreto $\mathrm{n}^{\circ} 2320$, de 19 de julho de 2000, que substituiu o "representante da Ordem dos Advogados do Brasil - Seção Paraná" por um "representante de entidade de classe dos Advogados", na composição do grupo de apoio técnico da ouvidoria.
} 
Secretário da Tesouraria Geral. Ambos trabalham na ouvidoria, no grupo de apoio administrativo. Faz-se necessário lembrar que a ouvidoria ainda conta com um representante da polícia militar e um representante da polícia civil no seu grupo de apoio técnico, como é de praxe na maioria das ouvidorias de polícia. Antes de chegar à ouvidoria, Bordenowski também ocupou vários cargos de assessor na Secretaria da Segurança Pública e na Corregedoria da Polícia, ao longo de vários governos. O ouvidor aponta a sua grande proximidade com o governador como uma das razões para o sucesso da sua gestão à frente da ouvidoria, de acordo com a sua avaliação ${ }^{51}$. Na prática, o mandato foi aumentado para dois anos e pode ser renovado sempre que houver interesse. Os relatórios de atividades são elaborados semestralmente e encaminhados ao Governo do Estado, Ministério da Justiça, Polícia Civil, Polícia Militar, Detran, Procuradoria de Justiça e outros órgãos competentes. Não são publicados porque seriam de "interesse específico", portanto limitado, mas são abertos ao público sob simples solicitação. O ouvidor, percebemos na entrevista, está muito animado com o projeto da União Européia para capacitar as ouvidorias (ver adiante, pág. 119), pois espera conseguir dinheiro para realizar audiências públicas por todo o estado e nas câmaras municipais, com o objetivo de divulgar o trabalho da ouvidoria.

\section{Pernambuco}

Em Pernambuco a Ouvidoria da Secretaria de Defesa Social foi instituída pelo Art. $2^{\circ}$, VII, do decreto $\mathrm{n}^{\circ} 22.149$ de 23 de março de 2000 sobre a regulamentação da Secretaria de Defesa Social, que transformou o cargo de Superintendente do Núcleo de Operações Táticas Especiais em Superintendente do Núcleo de Ouvidorias. O cargo originário tinha sido criado no ano anterior, pelo decreto $n^{\circ} 21.311$ de 3 de março de

\footnotetext{
${ }^{51}$ Depoimento dado ao autor a 3 de junho de 2005.
} 
1999, e era exercido pelo promotor aposentado, delegado de polícia aposentado e excorregedor da polícia civil de Pernambuco, Sueldo Vasconcelos Cavalcanti de Melo. Três anos mais tarde, o ato governamental $n^{\circ} 2.322$ de 10 de junho de 2003 transformou novamente o cargo em gestor de ouvidoria, nomeando simultaneamente o procurador do estado Luiz Guerra de Morais para substituir Sueldo Vasconcelos Cavalcanti de Melo. O ouvidor da Secretaria de Defesa Social de Pernambuco é nomeado pelo governador por indicação do Secretário de Defesa Social e não tem mandato. Por fim, a lei ${ }^{\circ}$ 12.452 de 4 de novembro de 2003, que dispõe sobre a proteção e defesa do usuário dos serviços públicos prestados pelo Estado de Pernambuco, detalhou melhor as atribuições das ouvidorias e obriga-as a elaborar um relatório semestral de suas atividades, para ser apresentado à autoridade superior.

Indagado a respeito das suas condições de trabalho, o ouvidor Luiz Guerra de Morais $^{52}$ se queixou da pequena estrutura da ouvidoria, que conta com apenas mais quatro funcionários (um motorista e três atendentes que também fazem as vezes de digitadores). Ressaltou, contudo, que a situação deve mudar em breve. Um projeto elaborado pela Secretaria de Defesa Social, e previsto para entrar em funcionamento em agosto de 2005, vai aumentar o quadro de pessoal da ouvidoria e possibilitar que ela funcione 24 horas por dia. Deve ser implantado, igualmente, um serviço de atendimento telefônico pelo 0800. Atualmente, aliás, ocorre uma situação que pode ser qualificada de curiosa: durante a noite a equipe da ouvidoria é substituída pelo Grupo Tático de Apoio Convencional (GTAC), vinculado à corregedoria da polícia e integrado por sete policiais militares de várias patentes que atendem às queixas da população e as encaminham diretamente à corregedoria, sem que estas possam ser apreciadas pela ouvidoria. Naturalmente, esta situação não inspira muita confiança nos usuários da

\footnotetext{
${ }^{52}$ Depoimento ao autor dado a 30 de maio de 2005.
} 
ouvidoria, e muitos deles preferem fazer as suas denúncias de forma anônima, o que é muito criticado pela corregedoria. "Mas mesmo sendo anônimas, elas são importantes," diz Luiz Guerra de Morais, "pois indicam que uma investigação pode revelar irregularidades. O policial não vai ser punido por causa da denúncia, mas devido a uma investigação posterior. Grave seria se o julgamento fosse feito com base na denúncia anônima." Há planos já anunciados pelo Secretário da Defesa Social de criar ouvidorias em todas as cidades importantes do estado, com a centralização dos trabalhos em Recife.

\section{Rio de Janeiro}

A ouvidoria da polícia do Rio de Janeiro foi criada pela lei $\mathrm{n}^{0} 3.168$ de 12 de janeiro de 1999, proposta pelo deputado estadual Carlos Minc (PT), que cinco meses depois submeteu à assembléia legislativa o projeto de lei $\mathrm{n}^{\mathrm{o}} 478 / 99$ com o objetivo de modificar a lei anterior e fortalecer a ouvidoria. Seis anos depois, contudo, o referido projeto ainda se encontra em tramitação na assembléia legislativa, onde enfrenta várias resistências. A criação de uma ouvidoria da polícia era também uma promessa de campanha do governador Anthony Garotinho (PDT), que tomou posse em 1999, de acordo com o plano de governo para a área da segurança pública elaborado pelo sociólogo Luiz Eduardo Soares que depois se tornou subsecretário de pesquisa e cidadania da segurança pública. A ouvidoria foi inaugurada a 16 de março de 1999, com a nomeação da socióloga Julita Lemgruber para o cargo de ouvidora. Um ano depois, contudo, Julita deixou a ouvidoria em solidariedade a Luiz Eduardo Soares, demitido pelo governador. Seguiram-se mais quatro ouvidores: Celma Pinto Duarte de Carvalho Alves, procuradora do estado, que tomou posse a 18 de abril de 2000 e permaneceu quatro meses no cargo; Mário Lúcio de Andrade Neves, advogado, que permaneceu um 
ano como ouvidor; Maria do Carmo Alves Garcia, promotora de justiça aposentada que é a titular da ouvidoria desde o dia 2 de outubro de 2001 até hoje, com uma interrupção de poucos meses, de 28 de novembro de 2002 ao início de 2003, período durante o qual o ouvidor foi o advogado Valdecir Nicácio de Lima. Nomeado ao final do governo de Benedita da Silva, Valdecir Nicácio de Lima foi vítima de um equívoco. Ao terminar o seu governo, Benedita da Silva exonerou todos os titulares de cargos importantes que tinham sido por ela nomeados, inclusive o ouvidor que teria direito a um mandato de dois anos. A sua sucessora no governo do estado, Rosinha Matheus, não perdeu tempo e recolocou no cargo de ouvidora Maria do Carmo Alves Garcia, mais da sua conveniência. Percebe-se que, apesar da lei que instituiu a ouvidoria garantir um mandato de um ano, com possibilidade de mais um mandato consecutivo, o que se observa é que as nomeações e demissões obedecem mais às conveniências políticas e à orientação do governador e do secretário de segurança pública que, oficialmente, é quem escolhe o ouvidor. A ouvidoria elabora relatórios trimestrais e anuais que podem ser acessados na página que mantém na internet. Dois terços dos 21 integrantes da equipe da ouvidoria, contudo, pertencem aos quadros de funcionários das polícias: são um delegado de polícia, um inspetor de polícia, dois coronéis, quatro sargentos e seis soldados da polícia militar.

\section{Rio Grande do Norte}

A Ouvidoria da Defesa Social do estado do Rio Grande do Norte foi instituída pela lei $\mathrm{n}^{\mathrm{o}} 7.851$ de 28 de junho de 2000, à qual foi acrescentada a lei complementar $\mathrm{n}^{\mathrm{o}} 231$ de 5 de abril de 2002. As atividades foram iniciadas em agosto de 2001, com a nomeação do advogado Marcos Dionísio Medeiros Caldas para o cargo de ouvidor. Com militância no movimento estudantil e na juventude católica, Caldas integrou a 
direção do PCdoB do Rio Grande do Norte, da qual se afastou para assumir o cargo na ouvidoria, e foi advogado do Centro de Direitos Humanos e Memória Popular (CDHMP), onde fundou um comitê de vítimas da violência no estado. Seis meses depois de inaugurada, a ouvidoria ganhou instalações próprias, sem nenhuma ligação com a secretaria de segurança pública do estado, inauguradas a 17 de dezembro de 2001. Trata-se de um conjunto de quatro salas grandes no "Espaço do Cidadão", também conhecido pelos nomes alternativos "Shopping Cidadão" ou "Central do Cidadão", um prédio localizado no centro de Natal onde se concentram vários órgãos públicos de atendimento à população como, por exemplo, concessionárias de serviços públicos e o ministério público. Se a parte física é muito boa, a parte operacional é o "calcanhar de aquiles" da ouvidoria de acordo com o seu titular ${ }^{53}$, que tem à sua disposição um advogado que é funcionário emprestado da corregedoria e faz as vezes de ouvidor-adjunto, um assistente social, três advogados, um motorista e um estudante de direito, contabilizando sete pessoas ao todo. Há um projeto de lei tramitando na assembléia legislativa para aumentar o quadro de funcionários e fortalecer a ouvidoria. O tema da violência policial entrou na agenda política estadual após o desbaratamento de um grupo de extermínio conhecido como Meninos de Ouro e comandado pelo exsecretário adjunto da Segurança Pública Maurílio Pinto de Medeiros, e a repercussão internacional que causou a morte de Francisco Gilson Nogueira, advogado do CDHMP, a 20 de outubro de 1996. O Rio Grande do Norte foi o segundo estado a elaborar um Programa Estadual de Direitos Humanos, em dezembro de 1998, e entre as metas de curto prazo inscrevia-se a instalação de uma ouvidoria da polícia. A ouvidoria, contudo, ainda enfrenta sérias resistências na sociedade local e o ouvidor demonstra ter muito jogo de cintura para poder desempenhar as suas funções.

\footnotetext{
${ }^{53}$ Depoimento dado ao autor a 12 de abril e a 10 de junho de 2005.
} 


\section{Rio Grande do Sul}

A Ouvidoria da Justiça e da Segurança do Estado do Rio Grande do Sul foi instituída pelo decreto $\mathrm{n}^{\mathrm{o}} 39.668$ de 17 de agosto de 1999, assinado pelo governador Olívio Dutra (PT), como órgão de fiscalização social de todas as atividades vinculadas à Secretaria da Justiça e da Segurança, o que abrange, além da Polícia Civil e da Brigada Militar, a Superintendência dos Serviços Penitenciários (Susepe), o Instituto Geral de Perícias (IGP) e o Departamento Estadual de Trânsito (Detran). O ouvidor é nomeado pelo governador, após indicação do Secretário de Estado da Justiça e da Segurança, para um mandato de dois anos, admitindo-se uma única recondução. A instalação da ouvidoria aconteceu na mesma data em que foi assinado o decreto que a criou, com a nomeação do ouvidor Luiz Goulart Filho, um advogado criminalista, ex-preso político da ditadura militar e membro do Movimento de Justiça e Direitos Humanos (MJDH). Luiz Goulart Filho esteve à frente da ouvidoria até o dia 9 de fevereiro de 2003, quando morreu ao tentar salvar a vida de duas crianças que se afogavam no mar, numa praia do litoral gaúcho. Um resultado importante da sua gestão foi a proposta de reforma do Regulamento Disciplinar da Brigada Militar, para permitir que os policiais tenham uma segunda atividade. O novo regulamento foi sancionado a 24 de setembro de 2001 e também acabou com a possibilidade de prisão do policial por infração administrativa, como chegar atrasado ou estar com a farda amassada. O sucessor de Luiz Goulart Filho é Jayme Eduardo Machado, advogado e subprocurador-geral da república aposentado. Dentre as suas contribuições está a proposta de um anteprojeto de lei para institucionalizar a ouvidoria de maneira mais permanente em substituição ao decreto vigente. O projeto de lei dá autonomia ao ouvidor para nomear os seus auxiliares, mas mantém a livre nomeação do titular da ouvidoria pelo governador, com mandato de dois anos renovável por igual período, coincidindo com o mandato do governador do estado. 
O Rio Grande do Sul é o primeiro estado a ter um delegado de polícia condenado por tortura no Brasil, com base na lei $n^{0}$ 9.455/97. A sentença de 16 anos de prisão acompanhada da perda do cargo foi proferida em primeira instância em abril de 2003 em resposta a um crime ocorrido em Irai, em agosto de $1998 . .^{54}$

\section{Santa Catarina}

A Ouvidoria da Secretaria de Segurança Pública e Defesa do Cidadão de Santa Catarina foi criada pela lei complementar $n^{\circ} 243$ de 30 de janeiro de 2003, referente à administração do estado e que previu também uma ouvidoria geral do estado, mas ainda aguarda a regulamentação das suas atividades, o que consta da proposta de Regimento Interno da Secretaria em tramitação nos órgãos de Planejamento e Administração Organizacional. A ouvidoria foi efetivamente instalada a 23 de abril de 2003, com a nomeação do advogado Cleto Navágio de Oliveira, que já foi Secretário de Administração do Governador Paulo Afonso Vieira (PMDB), de 1995 até 1998, ano em que se tornou Procurador Geral do Estado de Santa Catarina. Antes dele tinha sido nomeada ouvidora Hebe Teresinha Nogara que, contudo, não chegou a implantar a ouvidoria e foi remanejada para a Corregedoria da Fazenda Estadual, criada pela mesma lei que instituiu a ouvidoria. A competência da ouvidoria não se restringe aos atos dos integrantes da polícia civil e da polícia militar, pois recebe também denúncias relativas à polícia ambiental, ao corpo de bombeiros, aos agentes penitenciários, e aos servidores do Sistema de Administração Penal, do Sistema de Justiça e Cidadania, do Departamento de Defesa Civil, do Instituto Geral de Perícias e do DETRAN. O ouvidor é nomeado pelo governador após indicação do Secretário de Estado da Segurança Pública e Defesa do Cidadão, e pode ser exonerado a qualquer momento. De acordo

\footnotetext{
${ }^{54}$ Ver o Relatório Azul 2003, pág. 343, publicado pela Comissão de Cidadania e Direitos Humanos da Assembléia Legislativa do Estado do Rio Grande do Sul.
} 
com o ouvidor ${ }^{55}$, a ouvidoria não tem enfrentado dificuldades diretas, mas sim indiretas, como funcionários comissionados da Secretaria de Segurança Pública que estavam à sua disposição, que foram exonerados e não foram substituídos. Atualmente o quadro de funcionários da ouvidorias é composto pelo ouvidor, uma assistente administrativa emprestada pela SSPDS/SC, uma advogada e um estudante de administração da Universidade Federal de Santa Catarina (UFSC), sendo que os dois últimos trabalham só meio período. O primeiro relatório de atividades ainda está em fase de finalização, pois houve um problema de informática e todos os dados referentes a 2003 foram perdidos, sendo necessário recorrer à corregedoria para reavê-los. A previsão é que sejam realizados relatórios anuais.

\section{São Paulo}

A Ouvidoria da Polícia do Estado de São Paulo foi a primeira ouvidoria da polícia do país a ser criada e instalada, como já afirmamos anteriormente. Formalmente, ela foi criada pelo decreto $\mathrm{n}^{\mathrm{o}} 39.900$ de $1^{\mathrm{o}}$ de janeiro de 1995 , pelo governador Mário Covas (PSDB), no seu primeiro dia de governo, mas a sua inauguração só aconteceu a 20 de novembro de 1995, com a nomeação do sociólogo Benedito Domingos Mariano para o cargo de ouvidor. Dois anos depois, com o episódio de violência policial da Favela Naval, foram criadas as condições políticas para a aprovação da lei complementar $\mathrm{n}^{\mathrm{o}} 826$ de 20 de junho de 1997, que institucionalizou a ouvidoria. Foi estabelecido um mandato de dois anos para o cargo de ouvidor da polícia, admitindo-se uma única recondução. O mecanismo de escolha a partir de uma lista tríplice elaborada pelo CONDEPE foi mantido. A novidade foi a criação de cargos próprios da ouvidoria. O mandato de Benedito Domingos Mariano começou a contar a partir da aprovação da

\footnotetext{
${ }^{55}$ Depoimento dado ao autor em 17 de junho de 2003.
} 
nova lei e terminaria somente em junho de 2001, pois ele foi reconduzido pelo governador Mário Covas por sugestão do CONDEPE. No dia 31 de dezembro de 2000, contudo, Mariano pediu exoneração do cargo de ouvidor da polícia para assumir a função de ouvidor do município de São Paulo na administração da prefeita Marta Suplicy (PT) que se iniciou no dia $1^{\circ}$ de janeiro de 2001 . Foi então enviada uma nova lista tríplice ao governador que, muito doente, veio a falecer no início do ano. O vicegovernador Geraldo Alckmin (PSDB) manifestou menos apreço que o seu antecessor pela ouvidoria e a nomeação do novo ouvidor só aconteceu em maio de 2001. O escolhido foi Fermino Fecchio, um advogado com longa militância junto aos movimentos populares e organizações de direitos humanos, e que fora o braço direito de Benedito Domingos Mariano na ouvidoria da polícia. Fermino Fecchio enfrentou uma série de problemas e entrou em conflito com o governador, que não concordou com a indicação do CONDEPE de reconduzi-lo ao cargo ao término do seu mandato, em junho de 2003. A escolha do governador foi o advogado Itagiba Farias Ferreira Cravo, o terceiro nome da lista tríplice, que foi demitido pelo governador a 14 de março de 2005 , a três meses do final do seu mandato, após ter se envolvido em um acidente de automóvel que resultou em uma morte e o exame médico ter apontado que estava alcoolizado na ocasião. Surgiu então um impasse com a recusa do governador de todos os nomes da nova lista tríplice. Após semanas de insistência do CONDEPE e da Cúria Metropolitana o governador nomeou Benedito Domingos Mariano para um novo mandato, mas este recusou, preferindo permanecer na Secretaria de Gestão Estratégica da Prefeitura de Osasco. A situação só foi resolvida com a introdução de um nome mais palatável para o governador na lista tríplice, que a 3 de junho de 2005 escolheu o advogado ligado aos direitos humanos e à Igreja Católica Antonio Funari Filho como novo ouvidor da polícia. 


\subsection{Ouvidorias no Brasil}

O gráfico abaixo mostra a distribuição da instalação das ouvidorias ao longo dos anos:

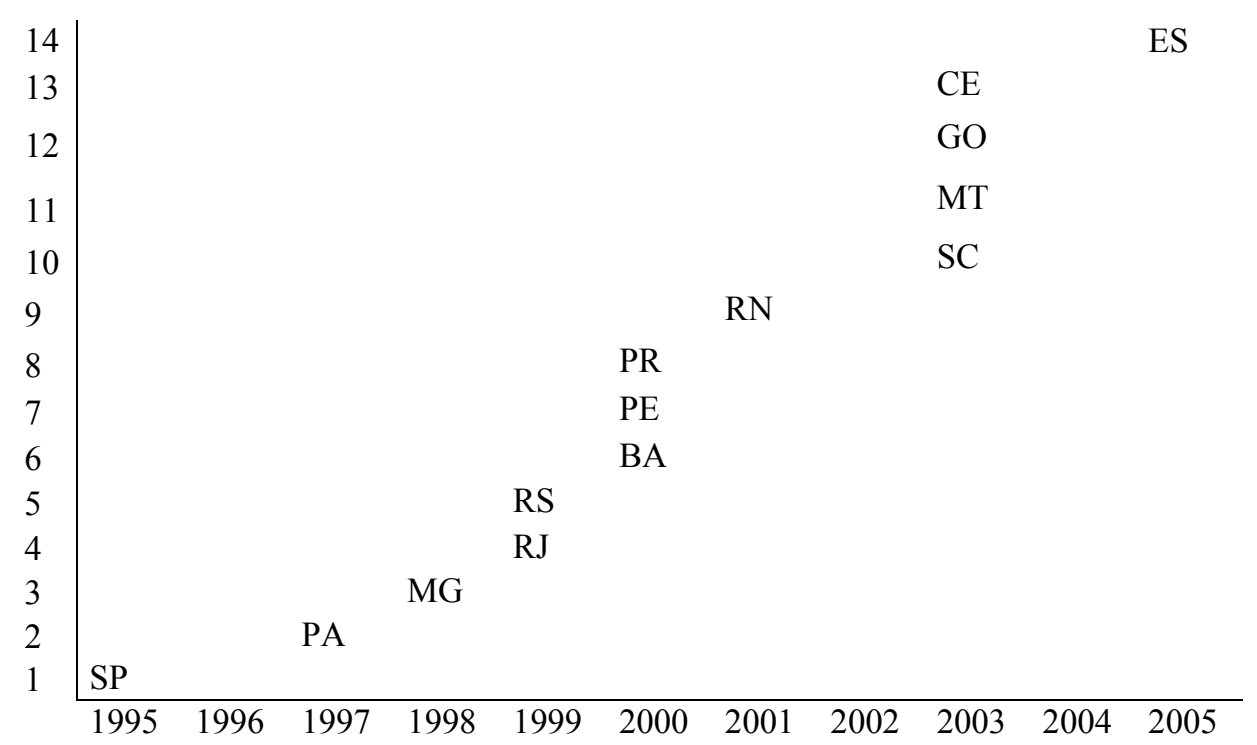

Nota-se que há uma tendência à instalação das ouvidorias em início de governo (cinco nos anos de 1999 e 2000, e quatro em 2003).

Ao sistematizar as informações a respeito da criação das ouvidorias de polícia e à nomeação dos primeiros ouvidores, constata-se que, na maioria dos casos, há um lapso de tempo entre a publicação da lei ou do decreto que deu origem à ouvidoria e a sua efetiva instalação, o que só acontece com a nomeação do primeiro ouvidor. Esse intervalo de tempo varia de alguns meses a mais de um ano e acontece preferencialmente quando a ouvidoria é criada por uma lei, sendo necessário um decreto do governador para efetivar a nomeação do ouvidor. 


\begin{tabular}{|c|c|c|c|c|}
\hline Estado & $\begin{array}{c}\text { Lei que instituiu a } \\
\text { ouvidoria da polícia }\end{array}$ & $\begin{array}{l}\text { Nomeação do } \\
1^{\circ} \text { ouvidor }\end{array}$ & Ouvidores & $\begin{array}{c}\mathrm{N}^{0} \\
\text { funcionários }\end{array}$ \\
\hline $\mathbf{B A}$ & $\begin{array}{l}\text { Decretos } 7.623 \text { de } \\
25 / 06 / 1999 \text { e } 8.572 \\
\text { de } 27 / 06 / 2003 \text { e lei } \\
9.006 \text { de } 04 / 02 / 2004\end{array}$ & $10 / 01 / 2000$ & Maria da Purificação de Lira & 11 \\
\hline $\mathbf{C E}$ & $\begin{array}{l}\text { Lei } 13.093 \text { de } \\
08 / 01 / 2001\end{array}$ & 2003 & $\begin{array}{l}\text { Cel. BM Franklin de Freitas } \\
\text { Lopes }\end{array}$ & 15 \\
\hline $\mathbf{E S}$ & $\begin{array}{l}\text { Lei } 5649 / 98 \text { de } \\
\text { 14/05/1998 revogada } \\
\text { pela lei } 297 \text { de } \\
\text { 27/07/2004 e pelo } \\
\text { decreto regulamentar } \\
\text { 1473-R de } 28 \text { de } \\
\text { março de } 2005\end{array}$ & 2005 & Sandro Chamon do Carmo & 1 \\
\hline GO & $\begin{array}{l}\text { Lei } 14.383 \text { de } \\
31 / 12 / 2002\end{array}$ & $\begin{array}{l}\text { Portaria } n^{0} 305 \\
\text { de } 8 / 09 / 2003\end{array}$ & Paulo Célio de Souza Leal & 19 \\
\hline MG & $\begin{array}{l}\text { Lei } 12.622 / 97 \text { de } \\
25 / 09 / 1997 \text { alterada } \\
\text { pela lei } 12.968 \text { de } \\
\text { 27/07/98, ambas } \\
\text { substituídas pela lei } \\
\mathrm{n}^{\circ} 15.298 \text { de } \\
06 / 08 / 2004 \\
\end{array}$ & 08/09/1998 & $\begin{array}{l}\text { José Roberto G. de Rezende } \\
(08 / 09 / 1998 \text {-ago2000)/ } \\
\text { Maria do Rosário Caiafa } \\
\text { Farias }(2000-2002) / \\
\text { José Francisco da Silva (a } \\
\text { partir de nov2002)(2 } \\
\text { mandato) }\end{array}$ & 32 \\
\hline MT & $\begin{array}{l}\text { Lei } 7.286 \text { de } \\
23 / 05 / 2000 \text { alterada } \\
\text { pela lei } 7.885 \text { de } \\
06 / 01 / 2003 \\
\end{array}$ & $\begin{array}{l}\text { Ato } \\
\text { administrativo } \\
18 / 07 / 2003\end{array}$ & $\begin{array}{l}\text { Auremácio José Tenório de } \\
\text { Carvalho }\end{array}$ & 2 \\
\hline PA & $\begin{array}{l}\text { Lei } 5.944 \mathrm{de} \\
06 / 02 / 1996\end{array}$ & Junho 1997 & $\begin{array}{l}\text { Rosa Marga Rothe (4 } \\
\text { mandatos)/ Lélio Railson Dias } \\
\text { de Alcântara }\end{array}$ & 23 \\
\hline $\mathbf{P E}$ & $\begin{array}{l}\text { Decreto } 22.149 \text { de } \\
23 / 3 / 2000 \text { e lei } \\
12.452 \text { de } 4 / 11 / 2003\end{array}$ & $23 / 3 / 2000$ & $\begin{array}{l}\text { Sueldo Vasconcelos } \\
\text { Cavalcanti de Melo/ Luiz } \\
\text { Guerra de Morais }\end{array}$ & 5 \\
\hline PR & 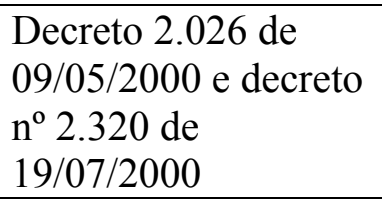 & $15 / 08 / 2000$ & $\begin{array}{l}\text { Almir Chagas Vilela/ } \\
\text { Luiz Alberto Franco } \\
\text { Bordenowski, }\end{array}$ & 17 \\
\hline RJ & $\begin{array}{l}\text { Lei n } 3.168 \text { de } \\
12 / 01 / 1999\end{array}$ & 16/03/1999 & $\begin{array}{l}\text { Julita Lemgruber/ Celma Pinto } \\
\text { Duarte de Carvalho Alves/ } \\
\text { Mário Lúcio Neves/ Maria do } \\
\text { Carmo Alves Garcia/ Valdecir } \\
\text { Nicacio/ Maria do Carmo } \\
\text { Alves Garcia }\end{array}$ & 19 \\
\hline $\mathbf{R N}$ & $\begin{array}{l}\text { Lei } 7.851 \text { de } \\
28 / 06 / 2000 \\
\text { e LC n }{ }^{\circ} 231 \text { de } \\
05 / 04 / 2002 \\
\end{array}$ & Agosto 2001 & $\begin{array}{l}\text { Marcos Dionísio Medeiros } \\
\text { Caldas }\end{array}$ & 7 \\
\hline
\end{tabular}




\begin{tabular}{|c|c|c|c|c|}
\hline Estado & $\begin{array}{l}\text { Lei que instituiu a } \\
\text { ouvidoria da polícia }\end{array}$ & $\begin{array}{l}\text { Nomeação do } \\
1^{\circ} \text { ouvidor }\end{array}$ & Ouvidores & $\begin{array}{c}\mathrm{N}^{\circ} \\
\text { funcionários }\end{array}$ \\
\hline RS & $\begin{array}{l}\text { Decreto } n^{0} 39.668 \text { de } \\
17 / 08 / 1999\end{array}$ & $17 / 08 / 1999$ & $\begin{array}{l}\text { Luiz Goulart Filho / } \\
\text { Jayme Eduardo Machado }\end{array}$ & 14 \\
\hline SC & $\begin{array}{l}\text { Lei Complementar } n^{\circ} \\
243 \text { de } 30 / 01 / 2003\end{array}$ & $23 / 04 / 2003$ & Cleto Navágio de Oliveira & 4 \\
\hline SP & $\begin{array}{l}\text { Decreto } n^{\circ} 39.900 \text { de } \\
01 / 01 / 1995 \text { e Lei } \\
\text { Complementar no } 826 \\
\text { de 20/06/1997 }\end{array}$ & 20/11/1995 & $\begin{array}{l}\text { Benedito Domingos Mariano } \\
(2 \text { mandatos }) / \text { Fermino } \\
\text { Fecchio/ Itagiba Farias } \\
\text { Ferreira Cravo/ Antonio Funari } \\
\text { Filho }\end{array}$ & 28 \\
\hline
\end{tabular}

Como pode ser comprovado no quadro acima, as ouvidorias mais antigas já foram comandadas por vários ouvidores, de modo que vários casos previstos nas leis que as instituíram já aconteceram: ouvidores que foram reconduzidos para mais um mandato ( $M G, P A, R J, R S, R N, S P$ ), outros que tiveram a recondução recomendada pela sociedade civil mas que foram vetados pelo governador (SP), nomes recusados pelo governador obrigando a sociedade civil a apresentar uma nova lista tríplice (SP), ouvidores que pediram demissão do cargo antes do final do mandato (RJ, SP), há o caso de dois ouvidores que não terminaram o mandato porque vieram a falecer antes do seu término (MG e RS) e de um outro que foi demitido por conduta incompatível com o cargo (SP).

Observa-se igualmente uma grande disparidade entre as ouvidorias quanto ao número de funcionários, que pode variar de um até pouco mais de trinta. Uma constatação a que chegamos ao longo desta pesquisa é que nas equipes pequenas o acesso ao ouvidor é mais fácil. Naturalmente, a questão da abertura do ouvidor a entrevistas depende muito do perfil do mesmo e do seu comprometimento com a razão de ser da ouvidoria: prestar contas à sociedade do trabalho da polícia. Parece-nos importante destacar as biografias de todos os titulares de ouvidorias de polícia, conforme quadro abaixo: 


\begin{tabular}{|c|c|c|}
\hline Estado & Ouvidor & Breve Biografia anterior à nomeação para a ouvidoria \\
\hline $\mathbf{B A}$ & $\begin{array}{l}\text { Maria da Purificação de } \\
\text { Lira }\end{array}$ & $\begin{array}{l}\text { Delegada da Polícia Civil da Bahia e membro atuante da } \\
\text { Associação dos Delegados da Bahia (ADPEB) }\end{array}$ \\
\hline $\mathbf{C E}$ & Franklin de Freitas Lopes & $\begin{array}{l}\text { Coronel do Corpo de Bombeiros Militar do Ceará, } \\
\text { bacharel em direito e sociologia e licenciado em educação } \\
\text { física, é também Coordenador Estadual dos Conselhos } \\
\text { Comunitários de Defesa Social }\end{array}$ \\
\hline $\mathbf{E S}$ & Sandro Chamon do Carmo & $\begin{array}{l}\text { Advogado com longa militância em direitos humanos, foi } \\
\text { Secretário de Justiça do Governo do ES, Secretário de } \\
\text { Cidadania e Direitos Humanos de Vila Velha, presidente } \\
\text { do Conselho Estadual de Direitos Humanos do ES, vice- } \\
\text { presidente da OAB/ES e membro da Comissão Justiça e } \\
\text { Paz do ES de } 1979 \text { a } 1987 \text {. }\end{array}$ \\
\hline GO & Paulo Célio de Souza Leal & $\begin{array}{l}\text { Funcionário público aposentado pertencente ao quadro da } \\
\text { Presidência da República, foi responsável pelo } \\
\text { Departamento de Articulação das Ações Policiais } \\
\text { Integradas na Secretaria Nacional de Segurança Pública } \\
\text { SENASP/MJ }\end{array}$ \\
\hline \multirow[t]{3}{*}{ MG } & $\begin{array}{l}\text { José Roberto Gonçalves de } \\
\text { Rezende } \\
\text { 08/09/1998-ago2000 }\end{array}$ & $\begin{array}{l}\text { Advogado criminalista, ativista de direitos humanos, ex- } \\
\text { preso político entre } 1971 \text { e 1979, foi assessor da bancada } \\
\text { do PT na Assembléia Legislativa de MG, assessor da } \\
\text { Corregedoria de Justiça do Estado e Procurador Geral da } \\
\text { Câmara de Belo Horizonte e da Beneficiência da } \\
\text { Prefeitura da capital. }\end{array}$ \\
\hline & $\begin{array}{l}\text { Maria do Rosário Caiafa } \\
\text { Farias } \\
\text { ago2000-nov2002 }\end{array}$ & $\begin{array}{l}\text { Procuradora do Estado aposentada, foi presidente do } \\
\text { Conselho Estadual de Direitos Humanos de Minas Gerais } \\
\text { (CONEDH), vereadora em Belo Horizonte de } 1993 \text { a } \\
1996 \text { pelo PT, tendo presidido a Comissão de Direitos } \\
\text { Humanos da Câmara Municipal e sido coordenadora de } \\
\text { Defesa de Direitos Humanos e Cidadania da Prefeitura de } \\
\text { Belo Horizonte. }\end{array}$ \\
\hline & $\begin{array}{l}\text { José Francisco da Silva } \\
\text { Nov2002- até hoje }\end{array}$ & $\begin{array}{l}\text { Psicólogo social e sanitarista, servidor público da UFMG, } \\
\text { foi secretário-adjunto de direitos humanos de MG (1999- } \\
\text { 2002), presidente do Conselho Deliberativo do Programa } \\
\text { de Proteção às vítimas e testemunhas ameaçadas de MG }\end{array}$ \\
\hline MT & $\begin{array}{l}\text { Auremácio José Tenório de } \\
\text { Carvalho } \\
\text { 18/07/2003 até hoje }\end{array}$ & $\begin{array}{l}\text { Sociólogo e advogado, professor da Faculdade de Direito } \\
\text { da UFMT, foi ouvidor da UFMT de } 2000 \text { a } 2003 \text { e é vice- } \\
\text { presidente do Fórum Nacional de Ouvidores } \\
\text { Universitários. Foi Coordenador Estadual do Projeto } \\
\text { Rondon e faz parte do Conselho Estadual de Defesa dos } \\
\text { Direitos da Pessoa Humana (CEDDPH/MT) }\end{array}$ \\
\hline PA & $\begin{array}{l}\text { Rosa Marga Rothe } \\
\text { Junho } 1997 \text { a } 22 / 08 / 2005\end{array}$ & $\begin{array}{l}\text { Pastora da Igreja Evangélica de Confissão Luterana, foi } \\
\text { presidente da Sociedade Paraense de Defesa dos Direitos } \\
\text { Humanos }\end{array}$ \\
\hline
\end{tabular}




\begin{tabular}{|c|c|c|}
\hline Estado & Ouvidor & Breve Biografia anterior à nomeação para a ouvidoria \\
\hline & $\begin{array}{l}\text { Lélio Railson Dias de } \\
\text { Alcantara } \\
\text { 22/08/2005 até hoje }\end{array}$ & $\begin{array}{l}\text { Bacharel em direito e delegado de polícia aposentado, foi } \\
\text { Corregedor Geral de Polícia, Delegado Geral de Polícia, e } \\
\text { Secretário de Segurança Pública do Pará. }\end{array}$ \\
\hline \multirow[t]{2}{*}{$\mathbf{P E}$} & $\begin{array}{l}\text { Sueldo Vasconcelos } \\
\text { Cavalcanti de Melo } \\
\text { 23/03/2000 a } 10 / 06 / 2003\end{array}$ & $\begin{array}{l}\text { Promotor de Justiça aposentado, delegado da Polícia Civil } \\
\text { de Pernambuco aposentado, foi Corregedor da Polícia } \\
\text { Civil. }\end{array}$ \\
\hline & $\begin{array}{l}\text { Luiz Guerra de Morais } \\
10 / 06 / 2003 \text { até hoje }\end{array}$ & $\begin{array}{l}\text { Procurador do Estado de Pernambuco, foi presidente da } \\
\text { Comissão Especial da Corregedoria da Secretaria de } \\
\text { Defesa Social }\end{array}$ \\
\hline \multirow[t]{2}{*}{ PR } & $\begin{array}{l}\text { Almir Chagas Vilela } \\
09 / 05 / 2000 \text { a } 01 / 01 / 2003\end{array}$ & $\begin{array}{l}\text { Delegado da Polícia Civil do Paraná aposentado, foi } \\
\text { professor da Universidade Federal do Paraná (UFPR) }\end{array}$ \\
\hline & $\begin{array}{l}\text { Luiz Alberto Franco } \\
\text { Bordenowski } \\
01 / 01 / 2003 \text { até hoje }\end{array}$ & $\begin{array}{l}\text { Escrivão da Polícia Civil do Paraná aposentado, é } \\
\text { membro atuante do Sindicato das Classes Policiais Civis } \\
\text { no Estado do Paraná (SINCLAPOL), foi assessor da } \\
\text { Corregedoria da Polícia e da Secretaria de Segurança } \\
\text { Pública do Paraná e faz parte da Comissão Estadual de } \\
\text { Direitos Humanos do Paraná (CEDH/PR) }\end{array}$ \\
\hline \multirow[t]{5}{*}{ RJ } & $\begin{array}{l}\text { Julita Lemgruber } \\
16 / 03 / 1999-17 / 03 / 2000\end{array}$ & $\begin{array}{l}\text { Socióloga, foi diretora geral do sistema penitenciário do } \\
\text { RJ }\end{array}$ \\
\hline & $\begin{array}{l}\text { Celma Pinto Duarte de } \\
\text { Carvalho Alves } 18 / 04 / 2000- \\
2 / 7 / 2000<?<31 / 08 / 2000\end{array}$ & $\begin{array}{l}\text { Procuradora de Justiça, foi coordenadora da comissão } \\
\text { Mãos Limpas criada pelo governador Anthony Garotinho } \\
\text { para investigar a banda podre da Polícia Civil do RJ }\end{array}$ \\
\hline & $\begin{array}{l}\text { Mário Lúcio de Andrade } \\
\text { Neves } \\
?-17 / 09 / 2001\end{array}$ & $\begin{array}{l}\text { Advogado, foi assessor jurídico do Conselho Federal de } \\
\text { Enfermagem (CONFEN). }\end{array}$ \\
\hline & $\begin{array}{l}\text { Maria do Carmo Alves } \\
\text { Garcia } 02 / 10 / 2001- \\
14 / 5 / 2002<?<28 / 11 / 2002 \text { e } \\
\text { jan 2003-hoje }\end{array}$ & $\begin{array}{l}\text { Promotora de Justiça aposentada e professora de direito } \\
\text { penal na Universidade de Barra Mansa/RJ }\end{array}$ \\
\hline & $\begin{array}{l}\text { Valdecir Nicacio de Lima } \\
\text { 28/11/2002-jan } 2003\end{array}$ & $\begin{array}{l}\text { Advogado, professor, combateu esquadrões da morte e as } \\
\text { más condições nas prisões, deixou o Brasil em } 1999 \text { sob } \\
\text { ameaças. Ao retornar, foi vice-presidente do Instituto de } \\
\text { Segurança Pública no governo de Benedita da Silva (PT) }\end{array}$ \\
\hline $\mathbf{R N}$ & $\begin{array}{l}\text { Marcos Dionísio Medeiros } \\
\text { Caldas }\end{array}$ & $\begin{array}{l}\text { Advogado, filiado ao PCdoB desde 1988, advogado do } \\
\text { Centro de Direitos Humanos e Memória Popular } \\
\text { (CDHMP), onde fundou o Comitê de Vítimas da } \\
\text { Violência no estado. }\end{array}$ \\
\hline \multirow[t]{2}{*}{ RS } & $\begin{array}{l}\text { Luiz Goulart Filho } \\
\text { 17/08/1999 a 09/02/2003 }\end{array}$ & $\begin{array}{l}\text { Advogado atuante na área criminal, ex-preso político da } \\
\text { ditadura militar, membro do Movimento de Justiça e } \\
\text { Direitos Humanos (MJDH) }\end{array}$ \\
\hline & Jayme Eduardo Machado & Advogado, subprocurador-geral da república aposentado \\
\hline SC & Cleto Navágio de Oliveira & $\begin{array}{l}\text { Advogado, foi Secretário de Administração do } \\
\text { Governador Paulo Afonso Vieira (PMDB), de } 1995 \text { até } \\
\text { 1998, quando se tornou Procurador Geral do Estado de } \\
\text { SC }\end{array}$ \\
\hline SP & $\begin{array}{l}\text { Benedito Domingos } \\
\text { Mariano 20/11/95-dez2000 }\end{array}$ & $\begin{array}{l}\text { Sociólogo, foi presidente do Centro Santo Dias de } \\
\text { Direitos Humanos }\end{array}$ \\
\hline
\end{tabular}




\begin{tabular}{|c|c|c|}
\hline Estado & Ouvidor & Breve Biografia anterior à nomeação para a ouvidoria \\
\hline & $\begin{array}{l}\text { Fermino Fecchio } \\
\text { Maio/2001-junho/2003 }\end{array}$ & $\begin{array}{l}\text { Advogado, funcionário público de carreira nas esferas } \\
\text { federal e municipal, eleito vereador em } 1988 \text { pelo PT foi } \\
\text { secretário municipal da Administração de } 1989 \text { a } 1992 \text {. } \\
\text { Foi presidente do Centro Santo Dias de Direitos Humanos } \\
\text { (1986-1992), coordenador do MNDH (1993-1996), } \\
\text { membro da Comissão de Direitos Humanos da OAB-SP } \\
\text { (1996-2000) e presidente do CONDEPE (1999-2000) }\end{array}$ \\
\hline & $\begin{array}{l}\text { Itagiba Farias Ferreira } \\
\text { Cravo } \\
\text { junho/2003-14/03/2005 }\end{array}$ & $\begin{array}{l}\text { Advogado, militante do Centro Santo Dias de Direitos } \\
\text { Humanos, foi exonerado do cargo de ouvidor pelo } \\
\text { governador após se envolver em um acidente de } \\
\text { automóvel que resultou em uma morte e o exame médico } \\
\text { ter apontado que estava alcoolizado na ocasião. }\end{array}$ \\
\hline & $\begin{array}{l}\text { Antonio Funari Filho } \\
\text { 03/06/2005 até hoje }\end{array}$ & $\begin{array}{l}\text { Advogado, antigo militante de esquerda da Ação Popular, } \\
\text { foi presidente da União Nacional dos Estudantes de } 1965 \\
\text { a 1966, ex-preso político, presidente da Comissão Justiça } \\
\text { e Paz da Arquidiocese de São Paulo, foi assistente } \\
\text { jurídico da Prefeitura de São Paulo na gestão de Mário } \\
\text { Covas, em 1984, delegado regional do trabalho em SP de } \\
1992 \text { até 2003, e suplente de deputado estadual pelo PT. }\end{array}$ \\
\hline
\end{tabular}

A análise do quadro mostra que há uma predominância clara das carreiras ligadas ao direito. Com efeito, dos 27 ouvidores arrolados acima, apenas quatro não têm uma biografia ligada diretamente à carreira jurídica: dois são sociólogos, um é psicólogo e outra é pastora. Faz-se necessário ressaltar que nos preocupamos apenas com os dados que sejam anteriores ou contemporâneos ao trabalho de ouvidor da polícia e que sejam relevantes para a função. Após ter sido ouvidor da polícia de São Paulo por cinco anos, por exemplo, Benedito Domingos Mariano se tornou ouvidor do município de São Paulo e secretário municipal de segurança, tendo adquirido experiência importante sobre o assunto das guardas municipais. ${ }^{56}$ A sua formação em sociologia e a sua militância em direitos humanos, contudo, é que o credenciaram para comandar a primeira ouvidoria de polícia instalada no país.

Um dado que salta à vista é o fato de vários ouvidores da polícia terem uma ligação próxima com as corporações policiais: são quatro delegados, um escrivão, um

\footnotetext{
${ }^{56}$ Ver, por exemplo, o seu livro Por um novo modelo de polícia no Brasil - A inclusão dos municípios no sistema de segurança pública, publicado em 2004 pela Editora Fundação Perseu Abramo.
} 
corregedor e um coronel da polícia militar. Verifica-se também um número considerável de integrantes da carreira do Ministério Público, são pelo menos sete promotores ou procuradores, sendo que muitos já estão aposentados. Observa-se ainda que quinze dos ouvidores são militantes de direitos humanos e que três deles destacam em suas biografias o fato de serem ex-presos políticos da ditadura militar. Outro dado que chama a atenção é a grande participação de quadros da administração pública, sendo que três deles já exerceram mandatos eletivos no legislativo e nove já serviram ao executivo, sem levar em conta os sete ouvidores que pertencem aos quadros da polícia. $\mathrm{O}$ fato de alguns ouvidores pertencerem à carreira policial depõe contra as ouvidorias que eles comandam, pois a necessária independência em relação às polícias, que é um pressuposto para o bom funcionamento de uma ouvidoria de polícia, fica comprometida, pelo menos aos olhos do público. Já é difícil, aliás, convencer os denunciantes de que as ouvidorias não são um órgão a mais na estrutura da polícia, quando formalmente elas são subordinadas às secretarias de segurança nos estados, como mostra o quadro abaixo:

\begin{tabular}{|c|c|c|c|c|}
\hline Estado & $\begin{array}{l}\text { Forma de indicação do } \\
\text { ouvidor }\end{array}$ & $\begin{array}{l}\text { Órgão a que é } \\
\text { subordinada a ouvidoria }\end{array}$ & $\begin{array}{l}\text { Mandato } \\
\text { do ouvidor }\end{array}$ & $\begin{array}{l}\text { Admite } \\
\text { recondução }\end{array}$ \\
\hline $\mathbf{B A}$ & $\begin{array}{l}\text { Indicação do Secretário da } \\
\text { Segurança Pública }\end{array}$ & $\begin{array}{l}\text { Secretaria de Segurança } \\
\text { Pública }\end{array}$ & $\begin{array}{l}\text { Cargo em } \\
\text { comissão }\end{array}$ & \\
\hline $\mathbf{C E}$ & Escolha do Governador & $\begin{array}{l}\text { Secretaria de Segurança } \\
\text { Pública }\end{array}$ & $\begin{array}{l}\text { Não tem } \\
\text { mandato }\end{array}$ & \\
\hline ES & $\begin{array}{l}\text { Indicação do Secretário de } \\
\text { Segurança Pública e Defesa } \\
\text { Social }\end{array}$ & $\begin{array}{l}\text { Secretaria de Estado da } \\
\text { Segurança Pública (SESP) }\end{array}$ & $\begin{array}{l}\text { Não tem } \\
\text { mandato }\end{array}$ & \\
\hline GO & Escolha do Governador & $\begin{array}{l}\text { Secretaria de Segurança } \\
\text { Pública e Justiça }\end{array}$ & $\begin{array}{l}\text { Não tem } \\
\text { mandato }\end{array}$ & \\
\hline MG & $\begin{array}{l}\text { Escolha do Governador a partir } \\
\text { de lista tríplice elaborada pelo } \\
\text { Conselho Estadual de Defesa } \\
\text { dos Direitos Humanos }\end{array}$ & Gabinete do governador & 2 anos & $\begin{array}{l}\text { Sim, uma } \\
\text { vez }\end{array}$ \\
\hline MT & $\begin{array}{l}\text { Escolha do Governador a partir } \\
\text { de lista tríplice elaborada pelo } \\
\text { Conselho Estadual de Defesa } \\
\text { dos Direitos da Pessoa Humana } \\
\text { (CEDDPH/MT) }\end{array}$ & $\begin{array}{l}\text { Secretaria de Justiça e } \\
\text { Segurança Pública }\end{array}$ & 2 anos & Sim \\
\hline
\end{tabular}




\begin{tabular}{|c|c|c|c|c|}
\hline PA & $\begin{array}{l}\text { Indicação do CONSEP, } \\
\text { presidido pelo Secretário de } \\
\text { Estado da Defesa Social }\end{array}$ & $\begin{array}{l}\text { Conselho Estadual de } \\
\text { Segurança Pública } \\
\text { (CONSEP) }\end{array}$ & 2 anos & $\begin{array}{l}\text { Sim, já } \\
\text { houve quatro } \\
\text { mandatos } \\
\text { sucessivos }\end{array}$ \\
\hline $\mathbf{P E}$ & $\begin{array}{l}\text { Indicação do Secretário de } \\
\text { Defesa Social }\end{array}$ & $\begin{array}{l}\text { Secretaria de Defesa } \\
\text { Social }\end{array}$ & $\begin{array}{l}\text { Não tem } \\
\text { mandato }\end{array}$ & \\
\hline PR & Escolha do Governador & $\begin{array}{l}\text { Secretaria de Estado da } \\
\text { Segurança Pública (SESP) }\end{array}$ & 1 ano & $\begin{array}{l}\text { Sim, uma } \\
\text { vez }\end{array}$ \\
\hline RJ & $\begin{array}{l}\text { Indicação do Secretário de } \\
\text { Segurança Pública }\end{array}$ & $\begin{array}{l}\text { Secretaria de Segurança } \\
\text { Pública }\end{array}$ & $\begin{array}{l}1 \text { ano }(\mathrm{em} \\
\text { tese) }\end{array}$ & $\begin{array}{l}\text { Sim, uma } \\
\text { vez (em tese) }\end{array}$ \\
\hline $\mathbf{R N}$ & $\begin{array}{l}\text { Escolha do Governador a partir } \\
\text { de lista tríplice elaborada pelo } \\
\text { Conselho Estadual de Defesa } \\
\text { dos Direitos Humanos }\end{array}$ & $\begin{array}{l}\text { Secretaria de Estado da } \\
\text { Segurança Pública }\end{array}$ & 2 anos & $\begin{array}{l}\text { Sim, uma } \\
\text { vez }\end{array}$ \\
\hline RS & $\begin{array}{l}\text { Indicação do Secretário de } \\
\text { Estado da Justiça e da } \\
\text { Segurança }\end{array}$ & $\begin{array}{l}\text { Secretaria da Justiça e da } \\
\text { Segurança }\end{array}$ & 2 anos & $\begin{array}{l}\text { Sim, uma } \\
\text { vez }\end{array}$ \\
\hline SC & $\begin{array}{l}\text { Indicação do Secretário de } \\
\text { Estado da Segurança Pública e } \\
\text { Defesa do Cidadão }\end{array}$ & $\begin{array}{l}\text { Secretaria Estadual de } \\
\text { Segurança Pública e } \\
\text { Defesa do Cidadão }\end{array}$ & $\begin{array}{l}\text { Não tem } \\
\text { mandato }\end{array}$ & \\
\hline SP & $\begin{array}{l}\text { Escolha do Governador a partir } \\
\text { de lista tríplice elaborada pelo } \\
\text { Conselho Estadual de Defesa } \\
\text { dos Direitos da Pessoa Humana } \\
\text { (CONDEPE) }\end{array}$ & $\begin{array}{l}\text { Secretaria da Segurança } \\
\text { Pública (SSP) }\end{array}$ & 2 anos & $\begin{array}{l}\text { Sim, uma } \\
\text { vez }\end{array}$ \\
\hline
\end{tabular}

Com exceção da ouvidoria da polícia de Minas Gerais, todas as outras fazem parte da estrutura administrativa da secretaria de segurança pública. Em muitas delas, aliás, a indicação do secretário da segurança pública é decisiva para a escolha do ouvidor. Assim, o ouvidor fica subordinado à mesma pessoa que comanda as polícias civil e militar e orienta a política de segurança no estado. A sociedade civil participa do processo de nomeação do ouvidor da polícia em apenas cinco estados (MG, MT, PA, RN e SP), sendo que o governador é quem toma a decisão final. Nos estados mencionados, com exceção do Pará, a sociedade civil elabora uma lista tríplice e a encaminha ao governador, que escolhe um dos três nomes propostos. A experiência mostra, contudo, que nem sempre a vontade manifestada pela sociedade civil é respeitada: o governador pode escolher o terceiro nome da lista ou até recusar todos os 
nomes, e a saída é elaborar uma nova lista. ${ }^{57}$ No Pará a situação é um pouco mais complexa. Quem nomeia o ouvidor da polícia é o Conselho Estadual de Segurança Pública (CONSEP) que é composto por 13 membros, sendo seis representantes do governo (1 dirigente da polícia civil, 1 dirigente da polícia militar, 1 representante do IML, 1 do Corpo de Bombeiros, 1 da Superintendência do Sistema Penal e 1 do Detran) e sete da sociedade civil (2 representantes da Assembléia Legislativa, 1 delegado de polícia, 1 representante da associação de policiais, 1 da Ordem dos Advogados do Brasil/PA, 1 da Sociedade Paraense em Defesa dos Direitos Humanos, 1 do Centro de Estudos e Defesa do Negro da Amazônia, e 1 do Centro de Defesa da Criança e do Adolescente). A ouvidora do sistema de segurança pública do Pará até agosto de 2005, Marga Rosa Rothe alerta, contudo, para o fato do conselho não ser paritário, pois dos sete representantes da sociedade civil três não seriam confiáveis, na sua avaliação: um dos deputados é também policial e não deveria ser considerado na cota da sociedade civil, da mesma forma que o delegado de polícia e o representante da associação dos policiais. Nem o representante da OAB/PA é garantido, pois depende de quem vem, frisa ainda a ouvidora. ${ }^{58}$

Uma segunda forma de avaliar a independência da ouvidoria da polícia em relação ao governo do estado é verificar se há um mandato para o ouvidor. Em caso afirmativo, o ouvidor não pode ser destituído do cargo antes do término do período estipulado, o que lhe confere uma certa liberdade para poder questionar a atuação dos agentes do estado em matéria de segurança pública. Nos casos em que há mandato mas o cargo de ouvidor é de livre nomeação pelo governador, mesmo que após indicação do

\footnotetext{
${ }^{57}$ Os dois casos aconteceram nas duas últimas nomeações para a ouvidoria da polícia do estado de São Paulo.

${ }^{58}$ Dois meses após ter prestados estes esclarecimentos, em entrevista realizada em junho, o CONSEP optou por não reconduzir a ouvidora, e nomeou o delegado de polícia aposentado Lélio Railson Dias de Alcantara como novo ouvidor do Sistema de Segurança Pública do Pará.
} 
secretário de segurança pública que lhe é subordinado, nem sempre a duração do mandato é respeitada, principalmente quando há troca de governo.

Quando as ouvidorias da polícia são ligadas administrativamente às secretarias de segurança pública, há ainda outro problema sério a ser considerado, pois além de se comprometer a independência do ouvidor, coloca-se em risco também a segurança das informações confiadas à equipe da ouvidoria. Quando as instalações materiais da ouvidoria se situam em prédios da secretaria de segurança pública, que também cede grande parte do contingente de funcionários para a ouvidoria, não é fácil convencer o público de que o devido sigilo da identidade do informante será mantido quando solicitado. Faz-se necessário ressaltar que, em muitos casos, para entrar nos prédios da secretaria de segurança pública, o visitante é obrigado a se identificar. Mesmo que ele solicite fazer uma denúncia anônima, a sua presença nas dependências da ouvidoria naquele dia pode muito bem ser registrada na portaria. No primeiro endereço da ouvidoria da polícia de São Paulo, por exemplo, na avenida Higienópolis, havia um soldado fardado na porta de sentinela e portando uma arma. Não é exatamente a recepção mais adequada para alguém que pretende fazer uma denúncia contra a polícia.

Por todos esses motivos, é desejável que os princípios de funcionamento das ouvidorias, independência e transparência, sejam reforçados, e a melhor maneira de fazê-lo é divulgar as suas atividades junto à sociedade. A elaboração de relatórios periódicos e a sua ampla divulgação tornam-se um imperativo, mas nem todas as ouvidorias têm as mesmas facilidades, como mostra o quadro abaixo: 


\begin{tabular}{|c|c|c|c|c|}
\hline Estado & $\begin{array}{l}\text { Periodicidade } \\
\text { dos relatórios } \\
\text { de atividades }\end{array}$ & Relatórios publicados & Site na internet & $\begin{array}{l}\text { Relatórios que } \\
\text { podem ser } \\
\text { acessados no site } \\
\text { (junho 2005) }\end{array}$ \\
\hline $\mathbf{B A}$ & Semestral & $\begin{array}{l}\text { Os relatórios não são } \\
\text { abertos ao público * }\end{array}$ & & \\
\hline $\mathbf{C E}$ & $\begin{array}{l}\text { Semanal e } \\
\text { anual }\end{array}$ & $\begin{array}{l}\text { Disponíveis sob } \\
\text { solicitação }\end{array}$ & & \\
\hline ES & & $\begin{array}{l}\text { Ainda não produziu } \\
\text { relatório }\end{array}$ & & \\
\hline GO & Semestral & $*$ & $\begin{array}{l}\text { http://www.sspj.go.gov. } \\
\text { br/ouvidoria.php }\end{array}$ & \\
\hline MG & Trimestral & $\begin{array}{l}\text { Publicado em forma de } \\
\text { livro: } 2003\end{array}$ & $\begin{array}{l}\text { http://www.ouvidoriada } \\
\text { policia.mg.gov.br }\end{array}$ & $\begin{array}{l}2004\left(1^{\mathrm{o}}, 2^{\mathrm{o}}, 3^{\mathrm{o}} \mathrm{e}\right. \\
\left.4^{\mathrm{o}} \text { trim }\right) \text { e } 2005\left(1^{\mathrm{o}},\right. \\
\left.2^{\mathrm{o}}, 3^{\mathrm{o}} \text { e } 4^{\mathrm{o}} \operatorname{trim}\right)\end{array}$ \\
\hline MT & Anual & $\begin{array}{l}\text { Disponíveis sob } \\
\text { solicitação }\end{array}$ & & \\
\hline PA & Anual & $\begin{array}{l}\text { Disponíveis sob } \\
\text { solicitação }\end{array}$ & $\begin{array}{l}\text { http://www.ouvidoria.ss } \\
\text { p.pa.gov.br }\end{array}$ & \\
\hline PE & Semestral & & & \\
\hline PR & Semestral & $\begin{array}{l}\text { Disponíveis sob } \\
\text { solicitação }\end{array}$ & $\begin{array}{l}\text { http://www.pr.gov.br/ou } \\
\text { vidoriadapolicia }\end{array}$ & \\
\hline RJ & $\begin{array}{l}\text { Mensal e } \\
\text { trimestral }\end{array}$ & $\begin{array}{l}\text { Disponíveis sob } \\
\text { solicitação }\end{array}$ & $\begin{array}{l}\text { http://www.direitoshum } \\
\text { anos.rj.gov.br }\end{array}$ & $\begin{array}{l}2004\left(1^{\mathrm{o}}, 2^{\mathrm{o}}, 3^{\mathrm{o}} \mathrm{e}\right. \\
\left.4^{\mathrm{o}} \text { trim. }\right) \text { e } 2005\left(1^{\mathrm{o}}\right. \\
\text { trim.) e mensais de } \\
\text { junho } 2004 \text { a } \\
\text { março } 2005\end{array}$ \\
\hline $\mathbf{R N}$ & $\begin{array}{l}\text { Trimestral e } \\
\text { anual }\end{array}$ & $\begin{array}{l}\text { Disponíveis sob } \\
\text { solicitação }\end{array}$ & $\frac{\text { http://www.ouvidoriasds }}{. \text { rn.gov.br }}$ & \\
\hline $\mathbf{R S}$ & Anual & $\begin{array}{l}\text { Publicado em forma de } \\
\text { livro: } 1999-2001\end{array}$ & $\begin{array}{l}\text { http://www.sjs.rs.gov.br } \\
\text { louvidoria }\end{array}$ & \\
\hline$\overline{S C}$ & Anual & $\begin{array}{l}\text { Ainda não produziu } \\
\text { relatório }\end{array}$ & & \\
\hline $\mathbf{S P}$ & $\begin{array}{l}\text { Trimestral e } \\
\text { anual }\end{array}$ & $\begin{array}{l}\text { Publicados em forma de } \\
\text { livro: 1996, 1997, 1998, } \\
\text { 1999, 2000, 2001, 2002 }\end{array}$ & $\begin{array}{l}\text { http://www.ouvidoria- } \\
\text { policia.sp.gov.br }\end{array}$ & $2002,2003,2004$ \\
\hline
\end{tabular}

Praticamente todas as ouvidorias são obrigadas pela lei que as instituiu a elaborar relatórios de atividades. A maioria delas torna estes relatórios públicos. Tratase de uma maneira importante de divulgar o seu trabalho, e é um bom critério para 
avaliar o compromisso para com a população e a independência ou não de uma ouvidoria em relação às secretarias de segurança pública. Como não há uma norma única para a elaboração, produção e divulgação destes relatórios, cada ouvidoria o faz a seu modo.

Várias ouvidorias mantêm páginas na internet, mas nem todas aproveitam para divulgar os seus relatórios por esse meio (apenas MG, RJ e SP). O motivo alegado com mais freqüência pelos ouvidores que não divulgam as informações relativas à sua ouvidoria na internet e a dificuldade em lidar com informática. Algumas ouvidorias publicam os seus relatórios em formato de livro ou brochura, que são distribuídos gratuitamente aos interessados (MG, RS e SP). As ouvidorias que não dispõem de tantas facilidades para a divulgação das suas atividades, enviam o seu relatório de atividades aos interessados sob simples solicitação, com algumas exceções. Ao entrar em contato com a Ouvidoria da Secretaria da Segurança Pública da Bahia, por exemplo, fomos informados de que os relatórios não são abertos ao público e se destinam unicamente às autoridades competentes (Secretário da Segurança Pública, Governador do Estado, Chefias da Polícia Civil e da Polícia Militar, Ministério da Justiça). Duas ouvidorias ainda estão em fase de instalação e não tinham produzido relatórios em junho de 2005 (ES e SC).

Observa-se que as ouvidorias que demonstram maior abertura à prestação de contas e à divulgação das suas atividades são, não apenas as mais antigas, mas também aquelas que surgiram após rumorosos episódios de violência policial que tiveram repercussão internacional, o que relacionamos no quadro abaixo: 


\begin{tabular}{|c|c|c|c|}
\hline Estado & $\begin{array}{c}\text { Episódio de violência policial } \\
\text { apontado pelos ouvidores como } \\
\text { decisivo para a instalação da } \\
\text { ouvidoria }\end{array}$ & Repercussão internacional & $\begin{array}{c}\text { Ano de } \\
\text { instalação } \\
\text { da } \\
\text { ouvidoria }\end{array}$ \\
\hline BA & & & 2000 \\
\hline $\mathbf{C E}$ & & & 2003 \\
\hline ES & & & 2005 \\
\hline GO & & & 2003 \\
\hline MG & $\begin{array}{l}\text { CPI do sistema carcerário mineiro, } \\
\text { em } 1997\end{array}$ & & 1998 \\
\hline MT & & & 2003 \\
\hline $\mathbf{P A}$ & $\begin{array}{l}\text { Massacre de } 19 \text { sem-terra em } \\
\text { Eldorado dos Carajás, em } 1996\end{array}$ & $\begin{array}{l}\text { Denúncia na Comissão de Direitos } \\
\text { Humanos da OEA }\end{array}$ & 1997 \\
\hline $\mathbf{P E}$ & & & 2000 \\
\hline PR & & & 2000 \\
\hline RJ & $\begin{array}{l}\text { Chacinas da Candelária e em } \\
\text { Vigário Geral, 1993. Violência } \\
\text { policial na favela Nova Brasília, } \\
\text { em 1995. Cidade de Deus, } 1997 \text { e } \\
1998 .\end{array}$ & $\begin{array}{l}\text { Denúncias na Comissão } \\
\text { Interamericana de Direitos Humanos } \\
\text { da OEA. Relatórios negativos da } \\
\text { Anistia Internacional e da Human } \\
\text { Rights Watch. } \\
\end{array}$ & 1999 \\
\hline $\mathbf{R N}$ & $\begin{array}{l}\text { Assassinato do advogado do } \\
\text { CDHMP Francisco Gilson } \\
\text { Nogueira pelo grupo de extermínio } \\
\text { Meninos de Ouro, em 1996. O } \\
\text { julgamento dos acusados aconteceu } \\
\text { em } 2001 \text {. }\end{array}$ & $\begin{array}{l}\text { Atendendo a um pedido da Human } \\
\text { Rights Watch, a Comissão de Direitos } \\
\text { Humanos da OEA solicitou } \\
\text { oficialmente ao governo brasileiro a } \\
\text { proteção policial para dez pessoas } \\
\text { ameaçadas de morte }\end{array}$ & 2001 \\
\hline $\mathbf{R S}$ & & & 1999 \\
\hline SC & & & 2003 \\
\hline SP & $\begin{array}{l}\text { Massacre no Carandiru, em } 1992 \\
\text { Caso da Favela Naval, em } 1997\end{array}$ & $\begin{array}{l}\text { Denúncias na OEA e manifestações } \\
\text { de protesto da Anistia Internacional. } \\
\text { Em } 13 \text { de abril de } 2000 \text {, no relatório } \\
\text { final no } 34 / 00 \text {, a Comissão } \\
\text { Interamericana de Direitos Humanos } \\
\text { da OEA declarou a responsabilidade } \\
\text { do Estado brasileiro pela morte dos } \\
111 \text { presos no Carandiru }\end{array}$ & $\begin{array}{l}1995 \text { e lei } \\
\text { aprovada } \\
\text { em } 1997\end{array}$ \\
\hline
\end{tabular}

Naturalmente, esses episódios de violência policial não dizem respeito unicamente aos estados nos quais eles aconteceram. Eles mancham a imagem do país no exterior. O policiamento, contudo, é uma atribuição estadual e está subordinada à autoridade dos governadores. Em conseqüência, o que está ao alcance do governo federal é incentivar a instituição de formas de controle da atividade policial nos estados. O Programa Nacional de Direitos Humanos, lançado pelo governo federal a 13 de maio 
de 1996, por exemplo, propõe como uma de suas metas "incentivar a criação de Ouvidorias de Polícia, com representantes da sociedade civil e autonomia de investigação e fiscalização”. Posteriormente, quatro estados também elaboraram os seus planos estaduais de direitos humanos (São Paulo em 1997, Rio Grande do Norte em 1998, Pernambuco em 1999, e Minas Gerais em 2001) que propõem criar ou fortalecer suas ouvidorias de polícia.

Nesse sentido é que, em julho de 1999, a Presidência da República criou, no âmbito da Secretaria de Estado dos Direitos Humanos, o Fórum Nacional de Ouvidores da Polícia, com a finalidade de "oferecer sugestões voltadas para o aperfeiçoamento institucional dos órgãos policiais, no que diz respeito à promoção e a proteção dos direitos humanos, e estimular a criação de novas ouvidorias de polícia". ${ }^{59}$ O Fórum é composto pelos ouvidores da polícia e coordenado por um dos seus integrantes, que se revezam a cada dois anos:

\begin{tabular}{|l|c|}
\hline Coordenadores do Fórum Nacional de Ouvidores da Polícia & Período \\
\hline Benedito Domingos Mariano (SP) & $1999-2000$ \\
\hline Luiz Goulart Filho (RS) & $2001-2002$ \\
\hline Rosa Marga Rothe (PA) & $2003-2004$ \\
\hline José Francisco da Silva (MG) & $2005-2006$ \\
\hline
\end{tabular}

O Fórum se reúne periodicamente para que os ouvidores compartilhem as suas experiências e possam coordenar as suas iniciativas no sentido de fortalecer e expandir as ouvidorias de polícia. Veja-se, por exemplo, no ANEXO 1, a Minuta de Projeto de Lei para a criação de uma ouvidoria da polícia proposta pelo Fórum. Alguns ouvidores, devido à sua subordinação hierárquica com as polícias, participam apenas como

\footnotetext{
${ }^{59}$ Decreto Presidencial de $1^{\circ}$ de junho de 1999, Portaria n 8 de 14 de julho de 1999 da Secretaria de Estado dos Direitos Humanos, e Portaria no 344 de 13 de julho de 1999 do Ministério da Justiça.
} 
observadores. $\mathrm{O}$ decreto que instituiu o Fórum é claro quanto à exigência da não subordinação do ouvidor em relação às instituições policiais.

Um outro instrumento que o governo federal tem para incentivar a instalação de ouvidorias é a ajuda financeira. Em 2003 e 2004, por exemplo, foram assinados os seguintes convênios entre a Secretaria Nacional de Segurança Pública/Ministério da Justiça (SENASP/MJ) e os governos estaduais abaixo relacionados e que envolvem, no total ou em parte, ajuda financeira para a instalação ou o reaparelhamento das ouvidorias:

\begin{tabular}{|l|l|l|l|}
\hline Estado & \multicolumn{1}{|c|}{ Valor total } & \multicolumn{1}{|c|}{ Vigência } & \multicolumn{1}{c|}{ Objeto do convênio } \\
\hline AP & R\$ 99.827,20 & $\begin{array}{l}22 / 11 / 2004 \text { a } \\
31 / 03 / 2005\end{array}$ & $\begin{array}{l}\text { Aquisição de mobiliário, equipamentos } \\
\text { áudio-visual, de informática e de uma rede } \\
\text { tecnológica, necessários à infra-estrutura } \\
\text { mínima para a estruturação dos serviços } \\
\text { propostos pela Ouvidoria de Polícia. }\end{array}$ \\
\hline BA & R\$ 1.487.507,94 & $\begin{array}{l}18 / 12 / 2003 \text { a } \\
04 / 03 / 2006\end{array}$ & $\begin{array}{l}\text { Reequipamento das Corregedorias e } \\
\text { Ouvidorias. Programa: Reaparelhamento. }\end{array}$ \\
\hline CE & R\$ 1.000.000,00 & $\begin{array}{l}01 / 12 / 2003 \text { a } \\
31 / 10 / 2005\end{array}$ & $\begin{array}{l}\text { Fortalecimento das ouvidorias e } \\
\text { corregedorias e realização de treinamento e } \\
\text { capacitação. Programa: Polícia Comunitária. }\end{array}$ \\
\hline GO & R\$ 43.000,00 & $\begin{array}{l}19 / 10 / 2004 \text { a } \\
31 / 03 / 2005\end{array}$ & $\begin{array}{l}\text { Aquisição de equipamentos e material } \\
\text { permanente, visando a qualificação dos } \\
\text { procedimentos realizados pela ouvidoria. }\end{array}$ \\
\hline MG & R\$ 1.081.820,50 & $\begin{array}{l}23 / 12 / 2005 \text { a } \\
31 / 05 / 2005\end{array}$ & $\begin{array}{l}\text { Aquisição de material de consumo e } \\
\text { contratação de serviços, visando a realização } \\
\text { de seminários de mobilização comunitária, } \\
\text { através da capacitação e debates, bem como } \\
\text { treinamento da equipe técnica que } \\
\text { desenvolve suas atividades na Ouvidoria de } \\
\text { Polícia do Estado, objetivando qualificá-la } \\
\text { no atendimento à população. }\end{array}$ \\
\hline MT & R\$ 111.200,00 & $\begin{array}{l}18 / 12 / 2003 \text { a } \\
17 / 01 / 2006\end{array}$ & $\begin{array}{l}\text { Implantação e operacionalização da } \\
\text { Ouvidoria de Polícia no Estado. Programa: } \\
\text { Reaparelhamento. }\end{array}$ \\
\hline
\end{tabular}

Fonte: http://www.mj.gov.br/transparencia/convenios_fnsp.htm

Nota-se que não é preciso dispor de muito dinheiro para instalar e aparelhar uma ouvidoria de polícia. Para poder usufruir destes convênios, basta que a ouvidoria 
apresente um projeto à SENASP e que, uma vez aprovado, haja concordância do governo do estado em assiná-lo.

Outro instrumento poderoso de que o governo federal dispõe para convencer todos os estados a instalar ouvidorias de polícia é condicionar uma parte da verba transferida aos estados à sua existência. Atualmente, $25 \%$ dos recursos repassados pelo Ministério da Justiça às Secretarias de Segurança Pública estaduais estão condicionados à existência de 18 critérios, dentre os quais figura a criação e o apoio a uma ouvidoria de polícia independente. ${ }^{60}$ De acordo com Fermino Fecchio, trata-se de uma reivindicação antiga do Fórum Nacional de Ouvidores de Polícia. ${ }^{61}$

Por mais que o governo federal estimule, contudo, a palavra final quanto à decisão de instalar ou não uma ouvidoria da polícia pertence aos governadores dos estados. Uma comparação entre os estados que têm e os estados que não têm ouvidoria de polícia pode revelar alguns aspectos interessantes, além de poder eventualmente mostrar a falta que faz uma ouvidoria.

\footnotetext{
${ }^{60}$ Depoimento dado ao autor por Ana Paulo Caldeira Souto Maior, Diretora Nacional do Programa de Apoio Institucional às Ouvidorias de Polícia e Policiamento Comunitário/SEDH/PR, a 10/06/2005.

${ }^{61}$ Depoimento dado ao autor a 2 de junho de 2005. Ver também a Ata da III ${ }^{a}$ Reunião do Fórum Nacional de Ouvidores da Polícia, realizada em Brasília, a 21 de maio de 2003.
} 
4.3 Comparação entre estados com ouvidoria e estados sem ouvidoria

Reunimos no quadro abaixo uma série de indicadores que podem estar relacionados à existência de uma ouvidoria de polícia nos estados.

\begin{tabular}{|c|c|c|c|c|c|}
\hline Estado & IDH (2002) & $\begin{array}{l}\text { PIB/capita } \\
\text { US\$(1999) }\end{array}$ & $\begin{array}{c}\text { Hab/PC+ } \\
\text { PM }\end{array}$ & $\begin{array}{c}\text { População } \\
\text { (2000) }\end{array}$ & $\begin{array}{c}\text { PC+PM } \\
\text { (2001) }\end{array}$ \\
\hline São Paulo & 0,814 & 4859 & 335,90 & 37.032 .403 & 110.248 \\
\hline Rio Grande do Sul & 0,809 & 3399 & 370,88 & 10.187 .798 & 27.469 \\
\hline Santa Catarina & 0,806 & 3031 & 369,53 & 5.356 .360 & 14.495 \\
\hline Rio de Janeiro & 0,802 & 3820 & 328,43 & 14.391 .282 & 43.819 \\
\hline Paraná & 0,786 & 2870 & 485,63 & 9.563 .458 & 19.693 \\
\hline Goiás & 0,770 & 1904 & 303,98 & 5.003 .228 & 16.459 \\
\hline Mato Grosso do Sul & 0,769 & 3285 & 335,38 & 2.078 .001 & 6.196 \\
\hline Espírito Santo & 0,767 & 2403 & 314,95 & 3.097 .232 & 9.834 \\
\hline Mato Grosso & 0,767 & 2147 & 393,21 & 2.504 .353 & 6.369 \\
\hline Minas Gerais & 0,766 & 2647 & 392,39 & 17.891 .494 & 45.596 \\
\hline Amapá & 0,751 & 1789 & 138,07 & 477.032 & 3.455 \\
\hline Roraima & 0,749 & 2250 & 177,17 & 324.397 & 1.831 \\
\hline Rondônia & 0,729 & 2552 & 295,02 & 1.379 .787 & 4.677 \\
\hline Tocantins & 0,721 & 600 & 312,22 & 1.157 .098 & 3.706 \\
\hline Pará & 0,720 & 1687 & 412,66 & 6.192 .307 & 15.006 \\
\hline Amazonas & 0,717 & 2350 & 395,91 & 2.812 .557 & 7.104 \\
\hline Rio Grande do Norte & 0,702 & 1575 & 339,00 & 2.776 .782 & 8.191 \\
\hline Ceará & 0,699 & 1187 & 554,20 & 7.430 .661 & 13.408 \\
\hline Bahia & 0,693 & 1590 & 410,77 & 13.070 .250 & 31.819 \\
\hline Acre & 0,692 & 1841 & 187,47 & 557.526 & 2.974 \\
\hline Pernambuco & 0,692 & 1437 & 359,01 & 7.918 .344 & 22.056 \\
\hline Sergipe & 0,687 & 1498 & 309,00 & 1.784 .475 & 5.775 \\
\hline Paraíba & 0,678 & 964 & 403,02 & 3.443 .825 & 8.545 \\
\hline Piauí & 0,673 & 792 & 392,66 & 2.843 .278 & 7.241 \\
\hline
\end{tabular}




\begin{tabular}{|l|l|l|l|l|l|}
\hline Maranhão & 0,647 & 837 & 711,59 & 5.651 .475 & 7.942 \\
\hline Alagoas & 0,633 & 1482 & 321,15 & 2.822 .621 & 8.789 \\
\hline
\end{tabular}

Fonte: Novo Atlas de Desenvolvimento Humano do Brasil, para o IDH; Segundo Relatório Nacional sobre os Direitos Humanos no Brasil, para os outros indicadores.

\section{Legenda:}

Com ouvidoria

Sem ouvidoria

\section{Comentários:}

- nenhum dos 7 estados com menos de 2,5 milhões de habitantes tem ouvidoria e todos os 9 estados com mais de 6 milhões de habitantes têm ouvidoria

142.415.952 dos brasileiros vivem em estados em que há ouvidoria de polícia, o que representa $84 \%$ da população brasileira de 169.799 .170 habitantes, de acordo com o censo realizado em 2000 pelo IBGE

- $\quad$ os 12 estados com maior efetivo policial (policiais civis + policiais militares) têm ouvidoria da polícia, ou seja todos os estados com efetivo policial superior a 9.000 policiais. Apesar do custo para manter em funcionamento uma ouvidoria de polícia ser pequeno quando comparado à maioria dos órgãos estaduais, ele pode ser uma explicação para esta relação, pois todas as ouvidorias de polícia são custeadas pela Secretaria de Segurança Pública dos 10 estados com maior IDH, apenas Mato Grosso do Sul não tem ouvidoria $^{62}$, e dos 16 estados com menor IDH, apenas 5 têm ouvidoria

\footnotetext{
${ }^{62}$ De acordo com informação de Fermino Fecchio, em depoimento dado ao autor, o estado de Mato Grosso do Sul já possui legislação para implantar uma ouvidoria da polícia, faltaria apenas a sua instalação. Não conseguimos, contudo, localizar a lei mencionada.
} 
- a relação entre o número de habitantes e o efetivo policial (Hab/PC+PM) não parece significativa quanto à existência ou não de ouvidorias

o PIB/capita também não parece ser significativo para explicar a existência de ouvidorias de polícia

$\mathrm{Na}$ tentativa de encontrar alguma relação entre os partidos no poder nos executivos estaduais e a criação de ouvidorias de polícia nos estados, listamos no quadro abaixo os governos em que foram instaladas ouvidorias de polícia:

\begin{tabular}{|l|l|l|l|}
\hline Estado & Data de inauguração & Governador & Partido \\
\hline SP & $20 / 11 / 1995$ & Mário Covas & PSDB \\
\hline PA & Junho 1997 & Almir Gabriel & PSDB \\
\hline MG & $08 / 09 / 1998$ & Eduardo Azeredo & PSDB \\
\hline RJ & $16 / 03 / 1999$ & Anthony Garotinho & PDT \\
\hline RS & $17 / 08 / 1999$ & Olívio Dutra & PT \\
\hline BA & $10 / 01 / 2000$ & César Borges & PFL \\
\hline PE & $23 / 03 / 2000$ & Jarbas Vasconcelos & PMDB \\
\hline PR & $09 / 05 / 2000$ & Jaime Lerner & PFL \\
\hline RN & $17 / 12 / 2001$ & Garibaldi Alves & PMDB \\
\hline SC & $23 / 04 / 2003$ & Luiz Henrique da Silveira & PMDB \\
\hline MT & $18 / 07 / 2003$ & Blairo Maggi & PPS \\
\hline GO & $08 / 09 / 2003$ & Marconi Perillo & PSDB \\
\hline CE & 2003 & Lúcio Alcântara & PSDB \\
\hline ES & Junho 2005 & Paulo Hartung & \\
\hline & & & \\
\hline
\end{tabular}


O quadro mostra que os governadores que criaram ouvidorias de polícia pertencem preferencialmente ao PSDB e ao PMDB. Deve-se considerar, contudo, que trata-se também dos dois partidos que mais elegeram governadores de estado nas últimas três eleições. Com efeito, se considerarmos o conjunto dos governadores eleitos em 1994, 1998 e 2002, tem-se a seguinte distribuição por partidos:

\begin{tabular}{|c|c|c|c|c|c|c|c|c|c|c|}
\hline \multicolumn{8}{|c|}{$\mathrm{N}^{\mathrm{o}}$ de governadores eleitos } & \multicolumn{3}{|c|}{$\mathrm{N}^{0}$ de ouvidorias criadas } \\
\hline \multicolumn{2}{|c|}{ Partido } & 1994 & 1998 & 2002 & Total & $\%$ & $\%$ & Ouvidoria & $\%$ & $\%$ \\
\hline \multirow{4}{*}{ 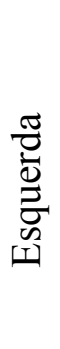 } & PPS & & & 2 & 2 & 2,5 & \multirow{4}{*}{26} & 1 & 7 & \multirow{4}{*}{28} \\
\hline & PSB & 2 & 2 & 4 & 8 & 10 & & 1 & 7 & \\
\hline & PDT & 1 & 1 & 1 & 3 & 3,5 & & 1 & 7 & \\
\hline & PT & 2 & 3 & 3 & 8 & 10 & & 1 & 7 & \\
\hline \multirow{2}{*}{ 离 } & PSDB & 7 & 6 & 7 & 20 & 25 & \multirow{2}{*}{50} & 5 & 35,5 & \multirow{2}{*}{57} \\
\hline & PMDB & 9 & 6 & 5 & 20 & 25 & & 3 & 21,5 & \\
\hline \multirow{3}{*}{ 苞 } & PSL & & & 1 & 1 & 1 & \multirow{3}{*}{24} & & & \multirow{3}{*}{15} \\
\hline & PPB & 4 & 2 & & 6 & 8 & & & & \\
\hline & PFL & 2 & 6 & 4 & 12 & 15 & & 2 & 15 & \\
\hline
\end{tabular}

A análise do quadro acima mostra que, se reagruparmos os dados em partidos de esquerda (PPS, PSB, PDT e PT), centro (PSDB e PMDB) e direita (PSL, PPB e PFL), há grande concordância entre as porcentagens de governos estaduais conquistados e a instalação de ouvidorias de polícia. Os números sugerem uma tendência dos partidos de esquerda e de centro de criar ouvidorias de polícia, ao contrário dos partidos de direita. Esse resultado já era esperado se levarmos em conta a visão tradicional que confere aos partidos de esquerda e de centro uma maior abertura à participação política e às formas 
de controle do poder. [BOBBIO, 1995] Esses números devem ser relativizados, contudo, pois o número de casos não é grande o suficiente para que o resultado tenha significância estatística. Além disso, há casos de governadores que mudaram de partido depois de eleitos, como é o caso de Jaime Lerner que foi eleito em 1994 governador do Paraná pelo PDT e depois se transferiu para o PFL, partido pelo qual foi reeleito em 1998, para um segundo mandato, durante o qual instalou a ouvidoria de polícia do Paraná.

A convicção pessoal do governador parece ser mais significativa para explicar a criação de uma ouvidoria de polícia do que o partido ao qual pertence. As ouvidorias de São Paulo e do Pará, por exemplo, criadas nos governos de Mário Covas e Almir Gabriel, ambos do PSDB, enfrentam sérias resistências dos seus sucessores Geraldo Alckmin e Simão Jatene, que pertencem ao mesmo partido. Em outro caso, José Ignácio Ferreira, eleito governador do Espírito Santo pelo PSDB em 1998, não colocou em funcionamento a ouvidoria da polícia do estado, criada pela lei $\mathrm{n}^{\circ} 5649 / 98$ de 14 de maio de 1998, e foi preciso esperar o governo de Paulo Hartung, eleito pelo PSB em 2002, para que a ouvidoria fosse instalada.

Em resumo, as 14 ouvidorias de polícia em atividade atualmente estão localizadas preferencialmente nos estados onde o IDH é maior ou naqueles em que houve um caso rumoroso de violência policial, com repercussão internacional, que levou o governo estadual a tomar providências no sentido de implantar mecanismos de controle da atividade policial. Este parece ser o caso das ouvidorias de polícia do Pará e do Rio Grande do Norte, que são bem atuantes.

Tentamos verificar se outras variáveis podem estar correlacionadas com a existência de ouvidorias - índices de criminalidade, existência de ONGs e movimentos 
de defesa dos direitos humanos atuantes - mas não foi possível chegar a nenhuma conclusão significativa.

A ausência de uma ouvidoria de polícia em um estado não significa que a atividade policial não seja monitorada pela sociedade civil. Algum tipo de controle externo sempre existe, mesmo que através de órgãos ou instituições cuja razão de existência não esteja diretamente ligada às forças policiais.

Um bom exemplo é o trabalho da Comissão de Cidadania e Direitos Humanos da Assembléia Legislativa do Estado do Rio Grande do Sul (CCDH), que publica anualmente o Relatório Azul. A comissão foi criada a 25 de junho de 1980, através da Resolução $\mathrm{n}^{\mathrm{o}} 1.817$, com o apoio de movimentos populares e de pessoas ligadas aos Direitos Humanos, logo após a promulgação da Lei da Anistia e no contexto da abertura democrática. Trata-se da primeira comissão a atuar na área dos direitos humanos em assembléias legislativas no Brasil. A sua forma de atuação consiste no encaminhamento das denúncias de violação de direitos, que chegam através de visitas, telefonemas, correspondência ou audiências públicas, para os órgãos responsáveis pela solução de cada situação: Defensoria Pública, Ministério Público, Corregedorias da Brigada Militar e da Polícia Civil, conselhos da sociedade, conselhos tutelares, instâncias do Poder Executivo e do Poder Judiciário. Os exemplares do Relatório Azul refletem essa diversidade. O Relatório Azul 2003, por exemplo, é dividido nos seguintes tópicos: crianças e adolescentes, direito internacional humanitário, mulheres, anos de chumbo, idosos, povos indígenas, povo negro, pessoas portadoras de necessidades especiais, violência urbana, direito à terra, sistema prisional, livre orientação sexual, violência policial, direito à saúde, sistema nacional de proteção aos direitos humanos.

No capítulo referente à violência policial, os relatórios publicam casos representativos das denúncias feitas à $\mathrm{CCDH}$ com o objetivo de "possibilitar a reflexão 
da sociedade sobre tais práticas" [Relatório Azul 1996], apresentam estatísticas fornecidas pelas corporações policiais referentes aos policiais mortos ou feridos em ação, bem como aos civis que sofreram algum tipo de excesso por parte da polícia. A partir da instalação da Ouvidoria da Justiça e da Segurança, um resumo dos relatórios da ouvidoria é também incluído.

Uma boa maneira de avaliar a quantidade e a importância desses meios alternativos a quem recorrem as vítimas de abusos policiais é verificar as fontes utilizadas para a preparação do Segundo Relatório Nacional sobre os Direitos Humanos no Brasil. Elaborado pelo Núcleo de Estudos da Violência da USP, a pedido do governo federal, o seu objetivo era verificar a situação dos direitos humanos no país nos três últimos anos do governo Fernando Henrique Cardoso. Os seus autores contaram com o apoio da Secretaria de Estado dos Direitos Humanos do governo federal que os ajudou a conseguir informações dos governos estaduais, do judiciário e do ministério público em cada estado, junto ao governo federal e aos órgãos federais, bem como a organizações da sociedade civil. Naturalmente, as ouvidorias de polícia, quando existem, ajudam muito na coleta de informações sobre a atuação da polícia nos estados, mas não são as únicas instâncias a que o cidadão pode recorrer e onde os pesquisadores foram buscar dados.

Com base neste relatório, organizamos na lista abaixo as instituições ou organizações que acompanham e relatam casos de violência policial na ausência de ouvidorias:

Instâncias Estaduais

Comissões de Direitos Humanos das Assembléias Legislativas 
- Comissões de Direitos Humanos das seções estaduais da Ordem dos Advogados do Brasil (OAB)

- Comissões Parlamentares de Inquérito nas Assembléias Legislativas

- $\quad$ Ministério Público estadual

- $\quad$ Corregedorias da Polícia

- $\quad$ Sindicatos de Trabalhadores Rurais

- $\quad$ Comissão Pastoral da Terra (CPT)

Instâncias Federais

Conselho de Defesa dos Direitos da Pessoa Humana (CDDPH)

Movimento Nacional de Direitos Humanos (MNDH)

Comissões Parlamentares de Inquérito no Congresso Nacional

Instâncias Internacionais

- $\quad$ Relatórios realizados por observadores internacionais

- $\quad$ Centro de Justiça Global

- $\quad$ Anistia Internacional

- Comissão Interamericana de Direitos Humanos da Organização dos Estados Americanos (OEA)

Human Rights Watch/Americas

Centro pela Justiça e pelo Direito Internacional (CEJIL)

Organizações da Sociedade Civil, com atuação em alguns estados (exemplos)

Gabinete de Assessoria Jurídica a Organizações Populares de Pernambuco (GAJOP) 
- $\quad$ Associação Sergipana de Prostitutas

- $\quad$ Centro de Estudos Cultura e Cidadania (CECCA) em Santa Catarina

- $\quad$ Fórum Estadual de Lutas por Terra, Trabalho, Cidadania e Soberania, no Paraná

Centro Santo Dias de Direitos Humanos da Arquidiocese de São Paulo

Comissão Teotônio Vilela de Direitos Humanos, em São Paulo

Associação de Mães e Familiares de Vítimas da Violência no Estado do Espírito Santo

Associação dos Cristãos para a Abolição da Tortura (ACAT), em Minas Gerais

Mídia

Jornais locais

Jornais de circulação nacional (Folha de S.Paulo, O Estado de S.Paulo, O Globo, Jornal do Brasil)

Com exceção dos grupos de trabalho para o controle da atividade policial do Ministério Público, das corregedorias da polícia e dos relatórios específicos muitas vezes elaborados por relatores internacionais, todas as outras instâncias não tratam apenas da violência policial, mas de direitos humanos em geral. Já vimos que os grupos de trabalho para o controle da atividade policial do Ministério Público são, no geral, muito pouco atuantes. Quanto às corregedorias da polícia e aos relatórios específicos, as primeiras não têm a independência necessária para investigar policiais, e os segundos são intermitentes e ocasionais, sendo, portanto, bastante limitados no tempo. O mesmo argumento pode ser lembrado para as Comissões Parlamentares de Inquérito. 
As ouvidorias da polícia são importantes por que representam uma instância permanente de monitoramento e controle da atividade policial, independente das corporações policiais. 


\subsection{Avaliação das ouvidorias de polícia}

Em documento datado de agosto de 1999, o Fórum Nacional de Ouvidores de Polícia aprovou as seguintes recomendações para a criação de ouvidorias de polícia:

"A - Os (as) Ouvidores (as) de Polícia dos Estados e da Polícia Federal terão para o exercício de suas atividades, autonomia e independência, sem vínculo de subordinação hierárquica com as polícias.

B - As leis ou decretos que instituem as Ouvidorias de Polícia devem assegurar:

- Mandato para o (a) Ouvidor (a)

- Corpo próprio de funcionários

- Sede própria

- Recursos financeiros para o desempenho de suas funções

- Que o (a) Ouvidor (a) tenha vínculo ou com a sociedade civil organizada, ou forte compromisso com o tema dos Direitos Humanos, comprovado por suas atividades anteriores

- Que o (a) Ouvidor (a) possa apresentar Relatórios Públicos de Prestação de Contas

- Que o (a) Ouvidor (a) possa oferecer sugestões ou recomendações voltadas para o aperfeiçoamento institucional dos órgãos policiais

- Que a Ouvidoria de Polícia possa Ter um conselho consultivo, composto de membros indicados pelo (a) Ouvidor (a).

C-Para ser Ouvidor (a) é necessário:

I- estar no gozo de seus direitos politicos

II - não ter qualquer vínculo com a Polícia Civil e Militar dos Estados e com a Polícia Federal, e nem ser membro destas instituições na ativa ou na aposentadoria."

Com base nestes critérios, podemos construir o seguinte quadro para poder avaliar as ouvidorias de polícia atualmente em atividade: 


\begin{tabular}{|c|c|c|c|c|c|c|c|c|}
\hline $\begin{array}{l}\text { Estad } \\
\text { o }\end{array}$ & $\begin{array}{l}\text { Mandat } \\
\mathrm{o}\end{array}$ & $\begin{array}{l}\text { Corpo } \\
\text { próprio de } \\
\text { funcionári } \\
\text { os }\end{array}$ & $\begin{array}{l}\text { Sede } \\
\text { própri } \\
\text { a }\end{array}$ & $\begin{array}{l}\text { Recursos } \\
\text { financeir } \\
\text { os } \\
\text { próprios }\end{array}$ & $\begin{array}{l}\text { Víncul } \\
\text { o com } \\
\text { os DH }\end{array}$ & $\begin{array}{l}\text { Relatório } \\
\mathrm{S} \\
\text { públicos }\end{array}$ & $\begin{array}{l}\text { Conselho } \\
\text { consultiv } \\
\text { o }\end{array}$ & $\begin{array}{l}\text { Ausênci } \\
\text { a de } \\
\text { vínculo } \\
\text { com a } \\
\text { polícia }\end{array}$ \\
\hline \multicolumn{9}{|l|}{ BA } \\
\hline $\mathrm{CE}$ & & & & & & $X$ & & \\
\hline ES & & & & & $\mathrm{X}$ & & & $X$ \\
\hline $\mathrm{GO}$ & & & & & & & & $X$ \\
\hline MG & $X$ & & & & $X$ & $X$ & & $X$ \\
\hline MT & $X$ & & & & $X$ & $X$ & & $X$ \\
\hline $\mathrm{PA}^{*}$ & $X$ & & & & $X$ & $X$ & $X$ & $X$ \\
\hline \multicolumn{9}{|l|}{$\mathrm{PE}$} \\
\hline PR & & & & & & $X$ & & \\
\hline $\mathrm{RJ}$ & & & & & & $X$ & & \\
\hline $\mathrm{RN}$ & $X$ & & $X$ & & $X$ & $X$ & & $X$ \\
\hline $\mathrm{RS}$ & $\mathrm{X}$ & & & & $\mathrm{X}$ & $X$ & $X$ & $X$ \\
\hline $\mathrm{SC}$ & & & & & & & & $X$ \\
\hline SP & $\mathrm{X}$ & $X$ & & & $X$ & $X$ & $X$ & $X$ \\
\hline
\end{tabular}

Todos os critérios estão relacionados aos princípios da autonomia e da transparência, que sempre devem pautar uma ouvidoria de polícia. Nota-se, contudo, que há um grupo de critérios mais diretamente dependentes do compromisso do ouvidor com o público em geral, e outro grupo de critérios mais relacionado com o exercício cotidiano da função de ouvidor (corpo próprio de funcionários, sede própria, recursos financeiros). Este segundo grupo revela-se insatisfatório em praticamente todas as ouvidorias. Faz-se necessário esclarecer que fomos bastante rígidos na avaliação destes critérios. Consideramos que uma ouvidoria só tem corpo de funcionários próprio se o ouvidor tem autonomia para nomear quem ele quiser, não sendo obrigado a escolher dentre os funcionários pertencentes à administração pública estadual ou até às 
corporações policiais. Ao nosso ver apenas a Ouvidoria da Defesa Social do Rio Grande do Norte possui sede própria, pois está localizada em um prédio que não tem ligação com a secretaria de segurança pública. Quanto aos recursos financeiros, todas as ouvidorias, sem exceção, dependem de verbas repassadas pelos secretários estaduais de segurança pública. Não resta dúvida, e muitos depoimentos dos ouvidores o confirmam, que muitos secretários de segurança tentam pressionar as ouvidorias condicionando a satisfação dos meios materiais a relatórios favoráveis.

Para que se possa ter uma idéia mais concreta a respeito da maneira quase heróica como são enfrentadas as dificuldades materiais e operacionais em algumas ouvidorias, apresentamos o seguinte relato que faz parte do primeiro relatório anual de atividades da Ouvidoria da Polícia de Mato Grosso (agosto de 2003 - agosto de 2004):

“A Ouvidoria de Polícia de Mato Grosso tem funcionado, até o presente momento, de forma precária, como segue:

1- SEDE PRÓPRIA - Até o presente momento não a possui. No período considerando no relatório, temos funcionado em sala cedida pela Corregedoria de Polícia Civil (a partir de novembro/2003), tendo funcionado junto ao CDDPH/MT e na própria Faculdade de Direito da UFMT, de onde é originário o Ouvidor. Ao funcionar junto a uma unidade policial, há a agravante de que a população sente-se inibida e constrangida em demandar, levando a que, utilizássemos a nossa sala na FD/UFMT para atender casos especiais e, liberássemos, mesmo com chamadas a cobrar, nosso telefone celular, para recebimento de denúncias. Isto, por certo, não é bom, pois limita o alcance da Ouvidoria e sua função precípua. Aguardamos a instalação da sede da Ouvidoria no prédio do Ganha Tempo, o que esperamos se concretize logo.

2- PESSOAL - A Ouvidoria de Polícia não conta, até o momento, com o apoio de pessoal especializado - assessorias mencionadas na lei, ou de apoio administrativo, tampouco veículo. Contamos, a partir de julho de 2004, com os serviços de uma estagiária de Direito que, antes dessa data, vinha tendo sua bolsa paga pelo Ouvidor, com recursos de sua gratificação.

3- MATERIAL DE EXPEDIENTE - A Ouvidoria não conta, até a presente data, com apoio institucional da Secretaria de Justiça $e$ 
Segurança Pública, em material de expediente e de informática. Todo o material necessário é por nós custeado.

4- PARTICIPAÇÃO EM EVENTOS - Do mesmo modo, temos participado em eventos regionais e nacionais por nossa custa.

5- VEÍCULO E EQUIPAMENTOS - Através de convênio entre o MJSecretaria Nacional de Polícia/Governo do Estado, conta a Ouvidoria de Polícia com recursos para sua estruturação, inclusive para a aquisição de veículo, equipamentos de informática e móveis, conforme plano de trabalho que anexamos.

Acreditamos, que estas condições de trabalho não podem continuar. A Ouvidoria de Polícia já existe há 14 meses. É necessário um respaldo institucional claro de que esta nova instituição responde aos anseios de maior transparência nos serviços prestados nessa difícil área e, portanto, também merece isonomia de tratamento face aos demais órgãos estaduais. "

Um projeto de cooperação entre a União Européia e o Brasil deve ajudar a resolver muitas destas limitações. Previsto para ser iniciado em julho de 2005, após quase sete anos de negociações para adequar as regras brasileiras às européias, o projeto tem por objetivo oferecer suporte institucional às ouvidorias de polícia em todo o país e ao policiamento comunitário no Rio de Janeiro. De acordo com o diagnóstico de JeanFrançois Olivier, que já foi representante internacional da Cruz Vermelha, e agora representa a União Européia no projeto, as ouvidorias de polícia brasileiras são fracas porque carecem de apoio político e financeiro, precisam ser reforçadas nas suas competências e na qualificação dos seus funcionários. ${ }^{63}$ De acordo com a exposição de motivos do projeto, cujo orçamento disponível de 6,5 milhões de euros até 2006, sendo que 4 milhões estão reservados para as ouvidorias de polícia, as atividades incluem:

- $\quad$ revisar e reforçar o status legal dos ouvidores de polícia nos níveis local e federal,

- treinar os ouvidores de polícia e os funcionários das ouvidorias,

\footnotetext{
${ }^{63}$ Depoimento dado ao autor a 10 de junho de 2005.
} 
- trocar experiências com instituições européias envolvidas no controle externo da atividade policial,

- aumentar a visibilidade das ouvidorias de polícia tanto para as autoridades quanto para a população,

fortalecer a integração dos ouvidores de polícia com as outras instituições encarregadas do controle da polícia,

- $\quad$ criar um banco de dados para os ouvidores para que possa servir de fonte de informação e comunicação entre eles, além de unificar e harmonizar os procedimentos.

De acordo com o relato de vários ouvidores, uma equipe de peritos europeus vem percorrendo todas ouvidorias de polícia para fazer um diagnóstico da situação de cada uma delas. Já estão programadas também viagens de alguns ouvidores e suas equipes ao Portugal, para conhecer o funcionamento da Inspetoria Geral da Administração Interna (IGAI), que é o órgão responsável pelo controle externo da atividade policial no país. De acordo com o depoimento de Ana Paula Caldeira Souto Maior, Diretora Nacional do Programa de Apoio Institucional às Ouvidorias de Polícia e Policiamento Comunitário da Secretaria Especial de Direitos Humanos e responsável pelo projeto de cooperação com a União Européia pelo governo brasileiro, Portugal foi escolhido por ter uma experiência de controle externo mais semelhante com a brasileira. Há planos também de programar visitas à Irlanda do Norte, que possui uma situação de violência policial muito grande que foi modificada com a implantação de uma ouvidoria. $^{64}$

\footnotetext{
${ }^{64}$ Ver depoimento dado ao autor a 10 de junho de 2005 e a Ata da Va Reunião do Fórum Nacional de Ouvidores, realizada em Belo Horizonte, a 27 de junho de 2004.
} 


\section{Conselho Consultivo}

A idéia dos conselhos consultivos é oferecer uma ajuda externa ao ouvidor, com personalidades ou conselheiros que não têm como pertencer ao quadro de funcionários da ouvidoria, para que seja possível enfrentar momentos de adversidade. Trata-se de um vínculo importante com a sociedade civil. Em alguns conselhos, contudo, há predominância clara de integrantes próximos às corporações policiais, como é o caso do CONSEP, no Pará, como já tivemos a ocasião de expor. Além disso, vários conselhos têm uma atuação muito apagada e esporádica. No Pará, por exemplo, o CONSEP, que deveria se reunir quinzenalmente, ainda não tinha se reunido nenhuma vez no ano de 2005, de acordo com depoimento da ouvidora Rosa Marga Rothe, em junho de 2005.

Descrição do funcionamento de uma ouvidoria de polícia

O dia a dia na ouvidoria

Quem visita uma ouvidoria de polícia não encontra muito movimento. Não há motivo para se preocupar com filas ou tempo de espera. $\mathrm{O}$ atendimento é imediato e o interessado recebe toda a atenção que precisar. Os atendentes estão sempre prontos para ouvir a sua história, esclarecer quais são os seus direitos como cidadão e oferecer sugestões sobre as medidas que podem ser tomadas. Em função da gravidade do seu relato, o visitante poderá ser encaminhado para várias pessoas. Tudo acontece num clima de informalidade como que estrategicamente estudado para diferenciar em tudo as ouvidorias das repartições policiais: não há uniformes nem hierarquias aparentes, circula-se com relativa facilidade por todos os ambientes e os atendentes são atenciosos e cordiais. ${ }^{65}$ Alguns denunciantes, até, se sentem tão à vontade que só querem desabafar e é preciso convencê-los da necessidade de formalizar a denúncia. Que o visitante

\footnotetext{
${ }^{65} \mathrm{Na}$ sala da ouvidora da polícia do Pará, por exemplo, o visitante depara-se até com um inesperado poster de Che Guevara, anunciando claramente a posição ideológica da ouvidora.
} 
eventual não se engane, porém, pois essa calma aparente não reflete a quantidade de trabalho realizada nas ouvidorias. Com efeito, a maioria das denúncias chega por telefone, e-mail ou fax. Na ouvidoria da polícia de São Paulo, que é a maior do país, em média duas pessoas procuram diariamente a ouvidoria para prestar queixa, mas o número de denúncias recebidas por dia é aproximadamente dez vezes maior.

Descrição do corpo de funcionários e das atribuições de cada um

De acordo com o Guia Prático de Funcionamento de uma Ouvidoria de Polícia, elaborado pelo Fórum Nacional de Ouvidores, é desejável que a equipe de funcionários que compõe as ouvidorias de polícia inclua, além do próprio ouvidor, dois representantes das polícias militar e civil, um grupo de apoio técnico - composto de uma assessoria jurídica, uma assessoria social, uma assessoria orçamentária e financeira, uma assessoria de informática - e um grupo de apoio administrativo subdividido, por sua vez, em dois setores, a secretaria executiva e o expediente geral. Inspirado na ouvidoria da polícia de São Paulo, este modelo assemelha-se bastante ao organograma desta ouvidoria. Como já vimos anteriormente, há muita diferença entre as ouvidorias quanto ao número de pessoas que nelas trabalham. Na medida do possível, contudo, elas tentam contemplar as funções descritas a seguir:

o ouvidor (ou a ouvidora) dirige os trabalhos e representa a ouvidoria frente à sociedade e junto às corporações policiais e aos demais órgãos de governo; os representantes das polícias militar e civil prestam assessoria à equipe da ouvidoria nos assuntos relativos à corporação à qual pertencem; 
os assessores jurídicos, que podem ser advogados ou estudantes de direito que trabalham como estagiários, são responsáveis pelas questões jurídicas e acompanham toda a tramitação das denúncias, em suas diversas instâncias nas corregedorias, no ministério público e no judiciário, e eventualmente até acompanham os denunciantes quando estes são chamados a depor em fases posteriores do processo jurídico; ajudam também na elaboração de projetos de lei e ajudam o ouvidor a escrever as sugestões para melhorar a atividade policial;

a assistente social é uma profissional de serviço social responsável por recepcionar, ouvir, orientar e auxiliar os denunciantes que se dirigem pessoalmente à ouvidoria, e traçar um perfil dos denunciantes;

o assessor de informática presta serviços na área de estatística e análise dos dados que devem ser formatados para serem incluídos nos relatórios de atividades e divulgados pela internet;

os atendentes recebem as denúncias comunicadas por telefone e as organizam para facilitar o seu processamento;

o assessor de imprensa faz a divulgação das atividades da ouvidoria junto aos meios de comunicação. 
Com base na estrutura da Ouvidoria da Polícia de São Paulo, apresentamos a seguir o organograma de uma ouvidoria:

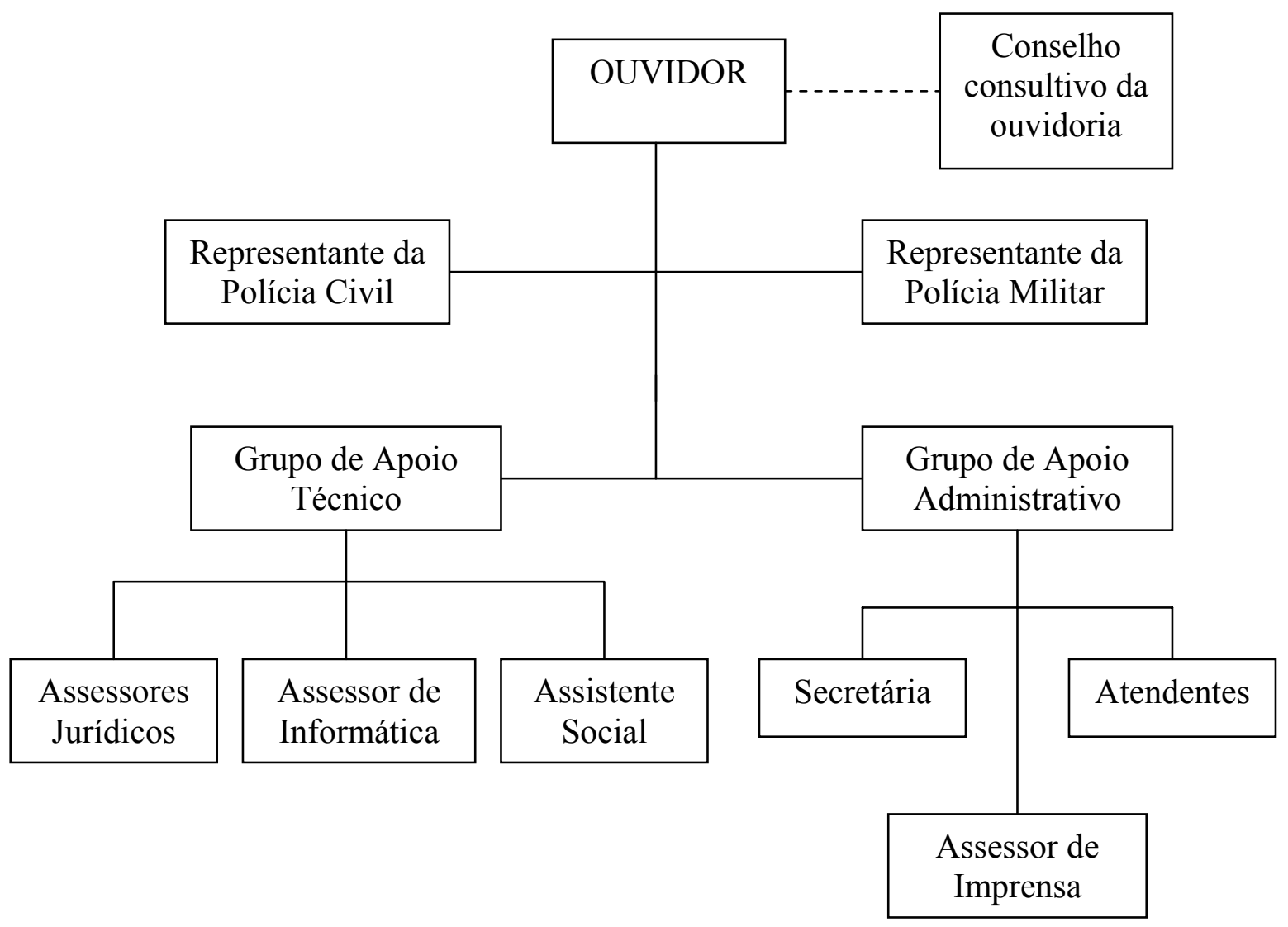

A atividade de uma ouvidoria de polícia consiste primordialmente em ouvir as denúncias dos cidadãos, encaminhá-las aos órgãos competentes pela sua apuração e acompanhar a sua tramitação, de maneira que possa ser oferecida uma resposta satisfatória ao denunciante. Este papel de intermediação entre o público e as instituições policiais define a atuação das ouvidorias em duas etapas.

$\mathrm{Na}$ primeira etapa, os atendentes recebem a denúncia e reúnem o máximo de informações possíveis sobre o denunciante e a sua versão do ocorrido, de modo a poder estabelecer um perfil dos denunciantes e a permitir o encaminhamento correto da denúncia. No ANEXO 2, transcrevemos o roteiro seguido pelos atendentes da 
Ouvidoria da Polícia de Minas Gerais ao receber as denúncias. A grande dificuldade, contudo, reside no fato de que uma parcela considerável dos denunciantes prefere permanecer no anonimato, decisão prontamente criticada pelas corregedorias das polícias.

A segunda etapa consiste no encaminhamento das denúncias e no acompanhamento da sua apuração. Os assessores das polícias civil e militar analisam as denúncias e verificam se há relevância para encaminhá-las às corregedorias ou se é preferível arquivá-las. Este procedimento se justifica, pois várias denúncias são muito imprecisas, o que torna muito difícil a identificação dos autores das infrações e resultaria invariavelmente em uma resposta negativa das corregedorias. Como as ouvidorias, assim como as corregedorias, possuem estruturas limitadas, é preferível concentrar os esforços nas denúncias com mínimas chances de resultarem em respostas satisfatórias para os denunciantes. Ressalte-se que este procedimento é comum em instituições semelhantes em outros países. [Delaunay, 1999] Em seguida vem a atuação da assessoria jurídica que tem por missão identificar os artigos dos códigos penais, civil ou militar nos quais se enquadram os fatos relatados e encaminhar a denúncia às respectivas corregedorias, da polícia civil ou da polícia militar. Se a resposta da corregedoria indicar que as medidas tomadas foram satisfatórias, com eventual punição do acusado, o caso é encerrado. Na hipótese contrária, pode ser solicitada uma revisão do caso pela corregedoria. Há também a possibilidade de recorrer diretamente ao ministério público, principalmente quando se trata de um caso grave ou que envolve a cúpula das polícias. ${ }^{66}$ Pode-se também verificar junto ao judiciário o andamento dos autos de um inquérito, ou requisitar a realização de um exame de corpo de delito, cujo laudo servirá para instruir o expediente em andamento. Quando se trata de denúncia de

\footnotetext{
${ }^{66}$ De acordo com o depoimento de Fermino Fecchio: "quando a coisa é muito grave, a critério do ouvidor, ele encaminha para quem tem um pistolão mais forte".
} 
policial contra superior hierárquico ou de relato de tortura, é solicitado que a apuração dos fatos seja feita com urgência.

Naturalmente, além de se traduzir em números e estatísticas que farão parte dos relatórios de atividades, todos estes procedimentos geram uma grande quantidade de ofícios e correspondências que precisam ser arquivados.

Fluxograma do encaminhamento das denúncias

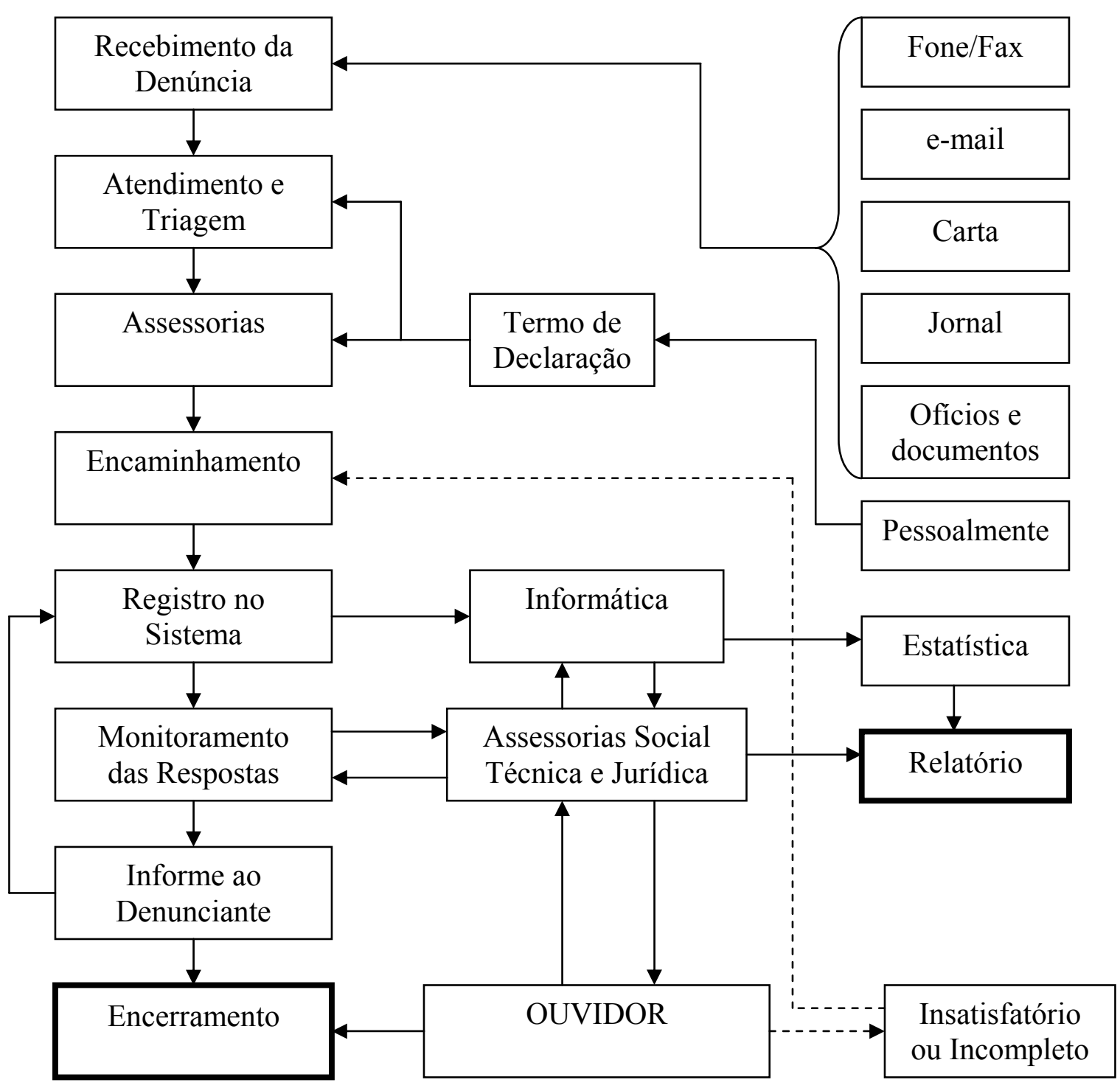




\section{Elaboração dos relatórios}

\section{Descrição dos relatórios}

Os relatórios variam bastante de uma ouvidoria para outra. Já mostramos que alguns relatórios são publicados em formato de livro ou publicados na internet, de maneira a garantir acesso facilitado aos interessados, enquanto que outros estão disponíveis apenas sob solicitação, e outros ainda não são abertos ao público. Outra diferença que salta à vista é o tamanho dos relatórios: alguns se limitam a uma dezena de páginas, enquanto que outros podem ter até 350 páginas. Para que se possa ter uma idéia da diversidade destes relatórios, relacionamos no quadro abaixo algumas características que eles apresentam quanto ao conteúdo. ${ }^{67}$

\begin{tabular}{|c|c|c|c|c|c|c|c|}
\hline & $\begin{array}{l}\mathrm{N}^{\mathrm{o}} \mathrm{de} \\
\text { página } \\
\mathrm{S}\end{array}$ & $\begin{array}{c}\text { Perfil dos } \\
\text { denunciante } \\
\mathrm{S}\end{array}$ & $\begin{array}{l}\text { Estatístic } \\
\text { a das } \\
\text { denúncia } \\
\text { s }\end{array}$ & $\begin{array}{c}\text { Perfil dos } \\
\text { denunciado } \\
\mathrm{S}\end{array}$ & $\begin{array}{l}\text { Puniçõe } \\
\text { s e } \\
\text { resposta } \\
\text { s }\end{array}$ & $\begin{array}{l}\text { Descrição de } \\
\text { casos } \\
\text { representativo } \\
\text { s }\end{array}$ & $\begin{array}{c}\text { Proposta } \\
\text { s de } \\
\text { melhoria } \\
\text { s }\end{array}$ \\
\hline $\mathrm{BA}$ & 10 & & $\mathrm{X}$ & & & & \\
\hline $\mathrm{CE}$ & 21 & & & & & & \\
\hline ES & & & & & & & \\
\hline GO & 8 & & & & & & \\
\hline $\begin{array}{l}\mathrm{M} \\
\mathrm{G}\end{array}$ & $\begin{array}{c}40 \mathrm{a} \\
74\end{array}$ & $X$ & $X$ & $X$ & & & \\
\hline MT & 41 & & $\mathrm{X}$ & & & $\mathrm{X}$ & $\mathrm{X}$ \\
\hline $\mathrm{PA}$ & $\begin{array}{c}35 \mathrm{a} \\
47\end{array}$ & $\mathrm{X}$ & $X$ & $X$ & $X$ & $X$ & $X$ \\
\hline
\end{tabular}

${ }^{67}$ Os relatórios a que tivemos acesso para construir este quadro são: Bahia (2004), Ceará (2004), Goiás (2004), Mato Grosso (2004), Minas Gerais (2003, 2004), Pará (2001, 2002, 2003), Paraná (2004), Rio de Janeiro (2002, 2003, 2004), Rio Grande do Norte (2001, 2002, 2003, 2004), Rio Grande do Sul (19992001, 2004), São Paulo (1996, 1997, 1998, 1999, 2000, 2001, 2002, 2003, 2004). Nota-se que as ouvidorias do Espírito Santo e de Santa Catarina ainda não produziram relatórios, e que não tivemos acesso aos relatórios da ouvidoria de Pernambuco. 


\begin{tabular}{|c|c|c|c|c|c|c|c|}
\hline & $\begin{array}{l}\mathrm{N}^{\mathrm{o}} \text { de } \\
\text { página } \\
\quad \mathrm{S}\end{array}$ & $\begin{array}{l}\text { Perfil dos } \\
\text { denunciante } \\
\text { s }\end{array}$ & $\begin{array}{c}\text { Estatístic } \\
\text { a das } \\
\text { denúncia } \\
\text { s }\end{array}$ & $\begin{array}{c}\text { Perfil dos } \\
\text { denunciado } \\
\text { s }\end{array}$ & $\begin{array}{l}\text { Puniçõe } \\
\text { s e } \\
\text { resposta } \\
\text { S }\end{array}$ & $\begin{array}{l}\text { Descrição de } \\
\text { casos } \\
\text { representativo } \\
\text { s }\end{array}$ & $\begin{array}{l}\text { Proposta } \\
\text { s de } \\
\text { melhoria } \\
\text { s }\end{array}$ \\
\hline \multicolumn{8}{|c|}{ 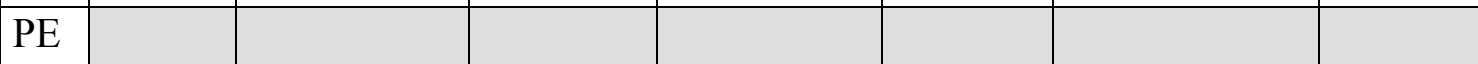 } \\
\hline $\mathrm{PR}$ & 19 & & $\mathrm{X}$ & & & & \\
\hline $\mathrm{RJ}$ & 34 & $\mathrm{X}$ & $X$ & $\mathrm{X}$ & $\mathrm{X}$ & & \\
\hline $\mathrm{RN}$ & $\begin{array}{c}20 a \\
36\end{array}$ & $X$ & $X$ & $X$ & & & \\
\hline $\mathrm{RS}$ & $\begin{array}{l}74 \mathrm{a} \\
126 \\
\end{array}$ & $X$ & $X$ & $\mathrm{X}$ & $\mathrm{X}$ & $X$ & \\
\hline \multicolumn{8}{|l|}{$\mathrm{SC}$} \\
\hline $\begin{array}{l}\text { SP } \\
1 *\end{array}$ & $\begin{array}{c}200 \mathrm{a} \\
350\end{array}$ & $\mathrm{X}$ & $X$ & $\mathrm{X}$ & $\mathrm{X}$ & $\mathrm{X}$ & $\mathrm{X}$ \\
\hline $\begin{array}{l}\text { SP } \\
2\end{array}$ & $\begin{array}{c}128 \mathrm{a} \\
140\end{array}$ & & $X$ & $X$ & $X$ & $X$ & \\
\hline $\begin{array}{l}\text { SP } \\
3\end{array}$ & 23 & & $X$ & $X$ & & & \\
\hline
\end{tabular}

* Os relatórios referentes à Ouvidoria da Polícia do Estado de São Paulo foram divididos em três grupos correspondentes ao mandato dos três primeiros ouvidores, pois há diferenças claras entre os relatórios.

Em alguns casos, a leitura dos relatórios revela o grau de comprometimento das ouvidorias com as corporações policiais que elas deveriam controlar. No relatório de atividades da Ouvidoria da Secretaria de Segurança Pública e Defesa Social do Ceará, referente ao ano de 2004, por exemplo, há maior destaque à quantidade de ofícios e correspondência trocados com outras entidades do que às denúncias contra a atuação da polícia. Dos onze assuntos mais abordados na ouvidoria, apenas três são desfavoráveis à polícia: reforço de policiamento, com 476 pedidos $(25,53 \%)$, denúncia contra policiais ou bombeiros, com 188 casos (10,08\%), e denúncia contra conselheiros, com 32 casos $(1,72 \%)$. Os outros oito assuntos são favoráveis à polícia: reuniões com os conselhos comunitários de defesa social, palestras e cursos educativos, criação e fortalecimento de 
conselhos, elogios a policiais, elogios ao site e aos serviços, apoio para a realização de projetos e eventos, resultado do concurso da polícia civil, início do curso de soldados da polícia militar.

Todos os relatórios a que tivemos acesso mencionam o número de denúncias recebidas. De um modo geral, nas ouvidorias que já produziram vários relatórios é possível verificar que há uma evolução positiva da quantidade de pessoas que procuram a ouvidoria ao longo do tempo. Este progresso é natural, pois à medida que a ouvidoria se estabelece e o seu trabalho se torna conhecido, a procura pelos seus serviços tende a aumentar. Para ilustrar este argumento é interessante observar os números referentes à Ouvidoria da Polícia de São Paulo:

Evolução do número de denúncias recebidas pela Ouvidoria da Polícia (SP)

\begin{tabular}{|l|l|l|l|l|l|l|l|l|l|}
\hline Ano & 1996 & 1997 & 1998 & 1999 & 2000 & 2001 & 2002 & 2003 & 2004 \\
\hline $\begin{array}{l}\mathrm{N}^{\circ} \text { de } \\
\text { denúncias }\end{array}$ & 2648 & 3784 & 3806 & 4834 & 4877 & 2637 & 2707 & 2723 & 3334 \\
\hline
\end{tabular}

\begin{tabular}{|c|c|c|c|c|}
\hline Ano & Período & $\mathrm{N}^{\circ}$ de denúncias & Ouvidor & Observação \\
\hline \multirow{4}{*}{1996} & $1^{\circ}$ trim. & 601 & \multirow{20}{*}{$\begin{array}{c}\text { Benedito } \\
\text { Domingos } \\
\text { Mariano }\end{array}$} & \\
\hline & $2^{\circ}$ trim. & 563 & & \\
\hline & $3^{\circ}$ trim. & 586 & & \\
\hline & $4^{\circ}$ quadrimestre & 898 & & \\
\hline \multirow{4}{*}{1997} & $1^{\circ}$ trim. & 802 & & \\
\hline & $2^{\circ}$ trim. & 1135 & & Favela Naval \\
\hline & $3^{\circ}$ trim. & 894 & & \\
\hline & $4^{\circ}$ trim. & 953 & & \\
\hline \multirow{4}{*}{1998} & $1^{\circ}$ trim. & 934 & & \\
\hline & $2^{\circ}$ trim. & 946 & & \\
\hline & $3^{\circ}$ trim. & 1074 & & \\
\hline & $4^{\circ}$ trim. & 1063 & & \\
\hline \multirow{4}{*}{1999} & $1^{\circ}$ trim. & 1234 & & \\
\hline & $2^{\circ}$ trim. & 1296 & & \\
\hline & $3^{\circ}$ trim. & 1155 & & \\
\hline & $4^{\circ}$ trim. & 1173 & & \\
\hline \multirow{4}{*}{2000} & $1^{\circ}$ trim. & 1449 & & \\
\hline & $2^{\circ}$ trim. & 1213 & & \\
\hline & $3^{\circ}$ trim. & 1131 & & \\
\hline & $4^{\circ}$ trim. & 1074 & & \\
\hline
\end{tabular}




\begin{tabular}{|c|c|c|c|c|}
\hline Ano & Período & $\mathrm{N}^{0}$ de denúncias & Ouvidor & Observação \\
\hline \multirow{4}{*}{2001} & $1^{\circ}$ trim. & 694 & vago & Sem ouvidor \\
\hline & $2^{\circ}$ trim. & 751 & \multirow{9}{*}{$\begin{array}{l}\text { Fermino } \\
\text { Fecchio }\end{array}$} & \\
\hline & $3^{\circ}$ trim. & 730 & & \\
\hline & $4^{\circ}$ trim. & 462 & & Mudança de \\
\hline \multirow{4}{*}{2002} & $1^{\circ}$ trim. & 490 & & endereço \\
\hline & $2^{\circ}$ trim. & 717 & & \\
\hline & $3^{\circ}$ trim. & 785 & & \\
\hline & $4^{\circ}$ trim. & 715 & & \\
\hline \multirow{4}{*}{2003} & $1^{\circ}$ trim. & 688 & & \\
\hline & $2^{\circ}$ trim. & 768 & & \\
\hline & $3^{\circ}$ trim. & 647 & \multirow{7}{*}{$\begin{array}{l}\text { Itagiba Farias } \\
\text { Ferreira Cravo }\end{array}$} & \\
\hline & $4^{\circ}$ trim. & 620 & & \\
\hline \multirow{4}{*}{2004} & $1^{\circ}$ trim. & 725 & & \\
\hline & $2^{\circ}$ trim. & 654 & & \\
\hline & $3^{\circ}$ trim. & 890 & & \\
\hline & $4^{\circ}$ trim. & 1065 & & \\
\hline \multirow{2}{*}{2005} & $1^{\circ}$ trim. & 960 & & \\
\hline & $2^{\circ}$ trim. & 1039 & vago & Sem ouvidor \\
\hline
\end{tabular}

Para facilitar a visualização, estes dados foram dispostos no gráfico a seguir:

Número de denúncias por trimestre na Ouvidoria da Polícia de São Paulo 


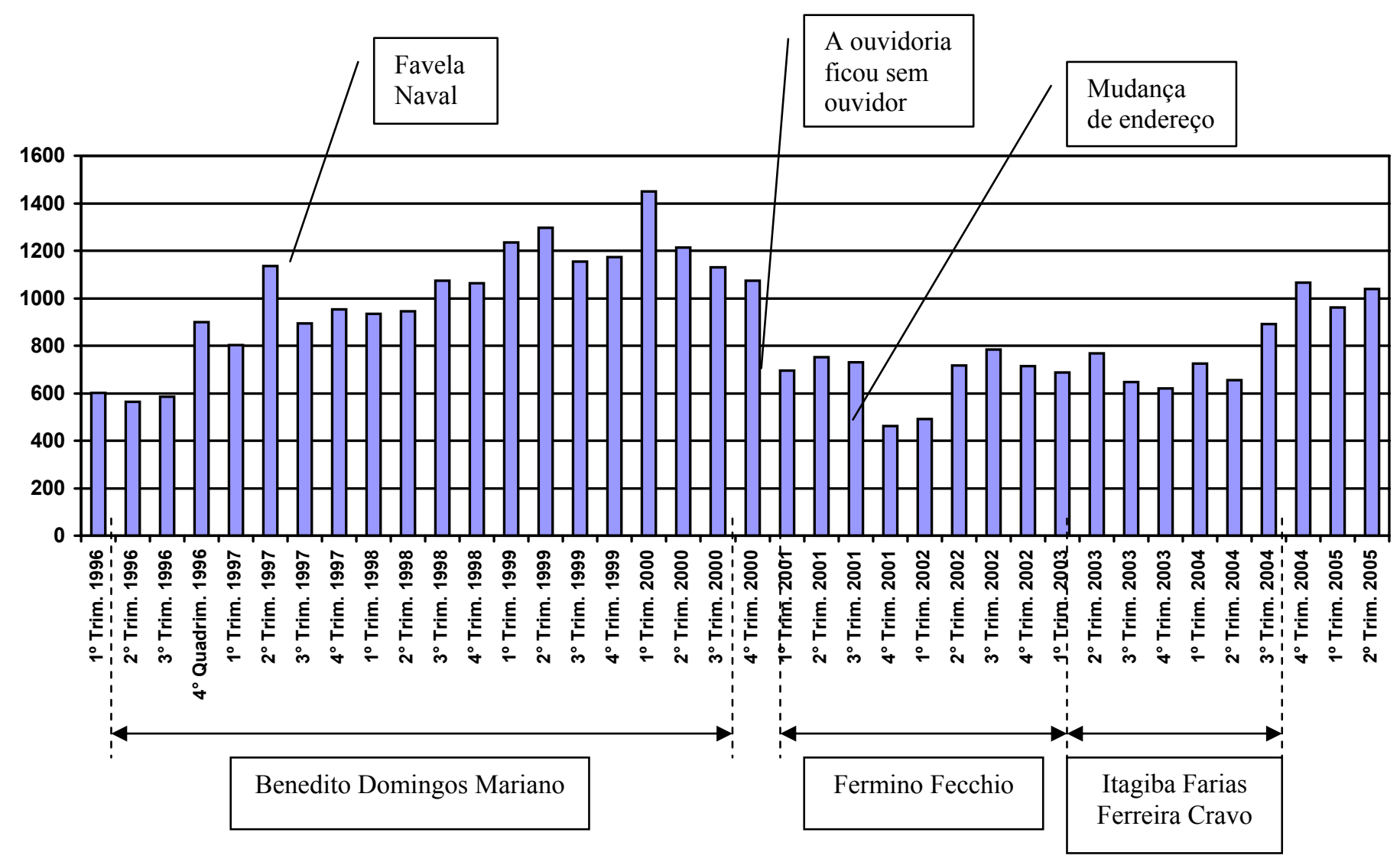

Nota-se que há uma lenta evolução do número de denúncias, que dobram nos três primeiros anos de existência da ouvidoria, havendo em seguida uma manutenção em torno da média de 1200 denúncias por trimestre, até o final de 2000 . No primeiro trimestre de 2001 a ouvidoria ficou sem seu titular e o número de denúncias caiu a 700. No quarto trimestre de 2001 e primeiro trimestre de 2002, a ouvidoria mudou de endereço, ficou em condições muito precárias, e o número de denúncias caiu para menos de 500 por trimestre. Faz-se necessário ressaltar que no segundo trimestre de 2005 a ouvidoria também ficou sem ouvidor, mas este fato não repercutiu no número de denúncias. A equipe da ouvidoria permaneceu ativa e trabalhando como estava acostumada a fazer. No primeiro trimestre de 2001, ao contrário, no período anterior em que a ouvidoria ficou sem ouvidor, a equipe foi desestruturada, pois vários funcionários acompanharam o então ouvidor da polícia, Benedito Domingos Mariano, em sua nova 
função, à frente da Ouvidoria Geral do Município de São Paulo. Somente após a nomeação do novo ouvidor, Fermino Fecchio, é que foi possível recompor a equipe da ouvidoria. Com isso, a capacidade de receber, apreciar e encaminhar as denúncias ficou bastante prejudicada. No período entre o último trimestre de 2001 e o primeiro trimestre de 2002, o que afetou a capacidade de trabalho da ouvidoria foi a mudança de endereço em condições muito precárias, o que atrasou significativamente o acompanhamento dos processos em andamento por uma equipe que ainda estava em fase de entrosamento. Em 2005 estes dois eventos se repetiram. No primeiro trimestre de 2005 a ouvidoria mudou novamente de endereço, e no segundo trimestre ela ficou sem ouvidor. Estes fatos, contudo, não exerceram uma influência significativa no número de denúncias. Seja como for, o número de denúncias trimestrais não recuperou mais o patamar que tinha atingido durante a gestão de Benedito Domingos Mariano, que fazia uso freqüente da mídia para promover e tornar conhecidas as ações da ouvidoria. Sempre resta saber, contudo, o número total de casos a denunciar.

Estas considerações nos levam a acreditar que, se a visibilidade do ouvidor afeta a atenção e a credibilidade que a população dedica a este órgão, o que se traduz por um maior número de denúncias, más condições de trabalho na ouvidoria podem causar uma queda brusca na quantidade de denúncias. Julita Lemgruber, a primeira ouvidora da polícia do Rio de Janeiro, confirma esta hipótese: "Na minha época, cada vez que publicava o relatório trimestral, aumentava muito o número de denúncias". ${ }^{6}$

Faz-se necessário ressaltar que os crimes computados nos relatórios não representam a totalidade dos crimes ou irregularidades cometidos por policiais, mas apenas aqueles que foram comunicados às ouvidorias pela população ou que a equipe da

\footnotetext{
${ }^{68}$ Depoimento dado ao autor a $1 / 8 / 2005$.
} 
ouvidoria achou que deveria acompanhar após tomar conhecimento deles pelos jornais ou quaisquer outros meios.

Veja-se, por exemplo, a comparação entre o número de homicídios cometidos por policiais, fornecido pelas secretarias de segurança pública, e tal qual revelado pelas denúncias recebidas nas ouvidorias. Naturalmente, as secretarias têm todo interesse em esconder estas estatísticas, o que torna muito difícil o seu acesso. Por este mesmo motivo, em alguns casos os números estão provavelmente subestimados. Mesmo assim, os números fornecidos pelas secretarias de segurança pública são maiores que os números computados pelas ouvidorias. Como dependem da disposição dos denunciantes em relatar os fatos à ouvidoria, os números da segunda tabela estão sujeitos a vários fatores subjetivos, dentre os quais destaca-se a confiança que os cidadãos depositam na ouvidoria.

Número de mortos pela polícia (fontes variadas)

\begin{tabular}{|c|c|c|c|c|c|c|c|c|c|}
\hline Estado & 1996 & 1997 & 1998 & 1999 & 2000 & 2001 & 2002 & 2003 & 2004 \\
\hline $\mathrm{BA}$ & & & & & 132 & 112 & & & \\
\hline $\mathrm{CE}$ & & & & & & & & & \\
\hline $\mathrm{ES}$ & & & & & & & & & 25 \\
\hline GO & & & & & \multicolumn{3}{|c|}{37} & & \\
\hline $\mathrm{MG}$ & & & & & & & 66 & 110 & \\
\hline MT & & & & & & & & & \\
\hline $\mathrm{PA}$ & & & & & & & & & \\
\hline $\mathrm{PE}$ & & & & & & & & & \\
\hline $\mathrm{RJ}$ & & & 397 & 289 & 427 & 596 & 897 & 1195 & 983 \\
\hline $\mathrm{RN}$ & & & & & & & & & \\
\hline $\mathrm{RS}$ & & & 44 & 30 & 26 & 24 & 22 & & \\
\hline $\mathrm{SC}$ & & & & & & & & & \\
\hline SP & 406 & 436 & 525 & 664 & 839 & 703 & 825 & 915 & 669 \\
\hline
\end{tabular}


Fontes: Governo do Estado da Bahia, Governo do Estado de Goiás, Secretaria de Segurança Pública do Rio de Janeiro, Secretaria de Segurança Pública de São Paulo, Secretaria de Justiça e Segurança do Rio Grande do Sul, Secretaria de Segurança Pública de Minas Gerais.

Número de procedimentos instaurados nas ouvidorias para homicídios cometidos por policiais

\begin{tabular}{|c|c|c|c|c|c|c|c|c|c|}
\hline Estado & 1996 & 1997 & 1998 & 1999 & 2000 & 2001 & 2002 & 2003 & 2004 \\
\hline $\mathrm{BA}$ & & & & & & & & & 4 \\
\hline $\mathrm{CE}$ & & & & & & & & & Não consta \\
\hline ES & & & & & & & & & \\
\hline $\mathrm{GO}$ & & & & & & & & & Não consta \\
\hline MG & & & & & & & & 32 & 45 \\
\hline MT & & & & & & & & & 9 \\
\hline $\mathrm{PA}$ & & & \multicolumn{3}{|c|}{$258 *$} & 95 & 70 & 67 & \\
\hline $\mathrm{PE}$ & & & & & & & & & \\
\hline PR & & & & & & & & & Não consta \\
\hline $\mathrm{RJ}$ & & & & \multicolumn{4}{|c|}{$227 * *$} & 22 & 14 \\
\hline $\mathrm{RN}$ & & & & & & 3 & 16 & Não consta & 10 \\
\hline $\mathrm{RS}$ & & & & \multicolumn{3}{|c|}{$41 * * *$} & & 1 & 2 \\
\hline $\mathrm{SC}$ & & & & & & & & & \\
\hline SP & 40 & 101 & 313 & 409 & 364 & 481 & 576 & 624 & 284 \\
\hline
\end{tabular}

* acumulado de 1997 a 2000 ** 1999 a $2002 \quad * * * 1999$ a 2001

Fontes: relatórios de atividades elaborados pelas ouvidorias.

Alguns relatórios não deixam explicito o número de homicídios cometidos por policiais. No relatório da ouvidoria do Paraná, por exemplo, há apenas uma categoria “abusos físicos", e não fíca claro que tipo de "abusos físicos” foram considerados.

Os números de homicídios cometidos por policiais relatados pela ouvidoria da polícia de São Paulo são bem maiores que os de outras ouvidorias. Uma possível explicação se deve ao fato de, neste estado, uma norma interna da Secretaria da Segurança Pública ${ }^{69}$ obrigar as corporações policiais a informar toda e qualquer morte devida à atuação policial à rede da polícia e ao gabinete do secretário da segurança pública, que repassa os dados à ouvidoria da polícia. Não há dados oficiais, nem estatísticas precisas, mas os funcionários da ouvidoria estimam que a grande maioria dos casos de homicídios acompanhados por eles tem origem nas informações repassadas

\footnotetext{
${ }^{69}$ Trata-se da resolução ${ }^{\circ}$ 516, assinada por José Afonso da Silva, que foi secretário da segurança pública do estado de São Paulo de janeiro 1995 a fevereiro 1999.
} 
pela polícia e em notícias de jornal. Os casos que foram instaurados a partir de denúncias não devem ultrapassar $10 \%$ ou $15 \%$. Com efeito, a tabela e o gráfico a seguir mostram que os números fornecidos pela secretaria de segurança pública e os procedimentos instaurados pela ouvidoria apresentam tendências relativamente semelhantes:

Homicídios cometidos por policiais em São Paulo

\begin{tabular}{|c|c|c|c|c|c|c|c|c|c|}
\hline & 1996 & 1997 & 1998 & 1999 & 2000 & 2001 & 2002 & 2003 & 2004 \\
\hline $\begin{array}{c}\text { Números da } \\
\text { SSP }\end{array}$ & 406 & 436 & 525 & 664 & 839 & 703 & 825 & 915 & 669 \\
\hline $\begin{array}{c}\text { Denúncias } \\
\text { na ouvidoria }\end{array}$ & 40 & 101 & 313 & 409 & 364 & 481 & 576 & 624 & 284 \\
\hline
\end{tabular}

Obs.: os números se referem a homicídios cometidos por policiais civis ou policiais militares, tanto em serviço quanto durante a folga.

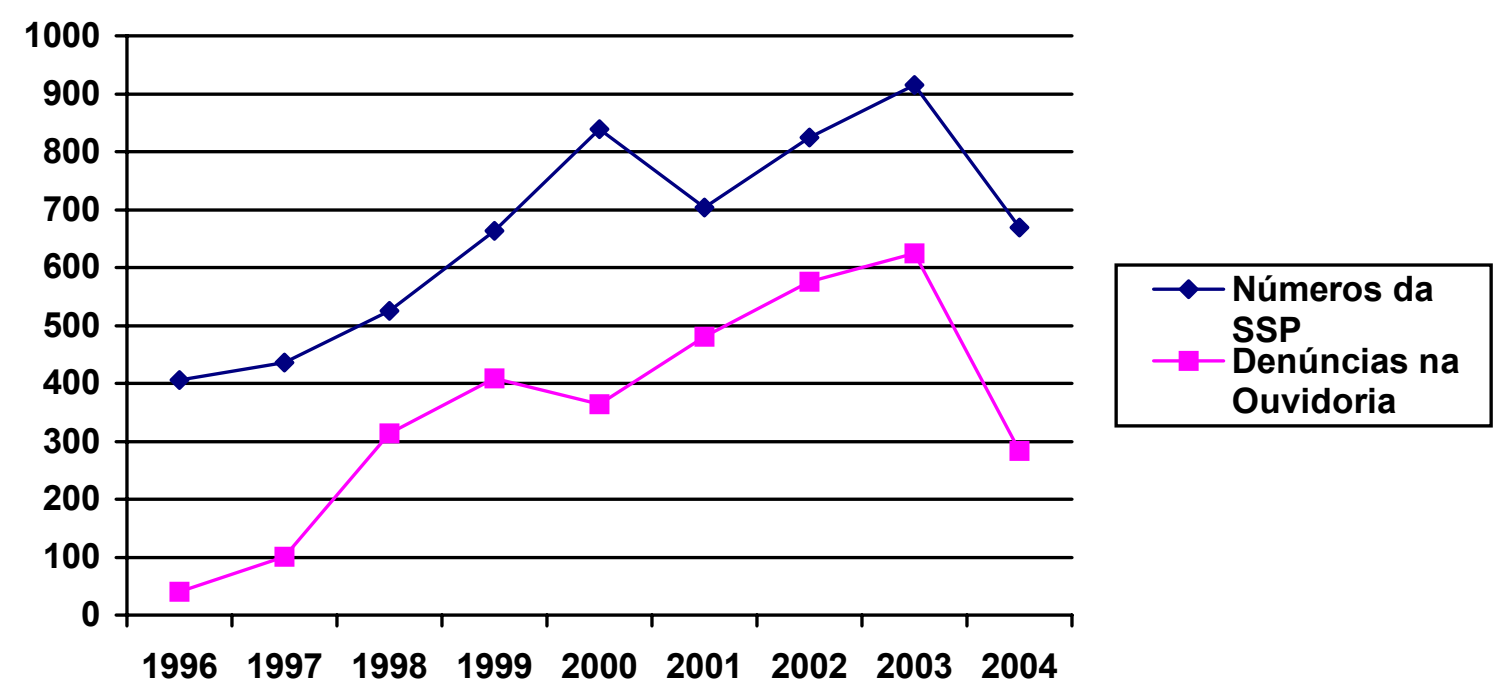

Observa-se, contudo, que os números da ouvidoria são sempre inferiores aos números oficiais divulgados pela secretaria de segurança pública. $\mathrm{O}$ bom senso nos levaria a esperar o contrário, pois o governo tem todo interesse em esconder alguns casos para diminuir o número de homicídios e a ouvidoria conta com outras fontes de informação como as denúncias e as notícias de jornal. De acordo com os esclarecimentos de Isabel Seixas de Figueiredo, que foi estagiária, assistente e assessora 
jurídica da ouvidoria desde sua criação até o final do mandato de Fermino Fecchio, nem todas as mortes cometidas por policiais eram comunicadas à ouvidoria e era preciso buscar outras fontes de informação. ${ }^{70}$ Duas fontes muito úteis eram a Comissão Especial para Redução da Letalidade em Ações envolvendo Policiais, instituída em dezembro de 2000 pela Secretaria de Segurança Pública como uma resposta à Pesquisa sobre o uso da força letal por policiais de São Paulo no ano de 1999, realizada pela ouvidoria $^{71}$, e um documento interno da polícia militar, o Informativo de Ocorrência, um boletim diário recebido pelo representante da polícia militar na ouvidoria em que 80 a $90 \%$ das mortes da polícia militar são relatadas. O único ano em que as curvas do gráfico acima apresentam discrepância é o de 2000, quando o número fornecido pela secretaria de segurança pública para os homicídios cometidos por policiais sobe e os números da ouvidoria apresentam uma queda. Ainda segundo Isabel Seixas de Figueiredo, esta diminuição pode estar relacionada com a criação do disque-denúncia, no ano de 2000, pelo governo estadual em parceria com o Instituto São Paulo contra a Violência. ${ }^{72}$ Com efeito, o lançamento do disque-denúncia mereceu muito destaque nos meios de comunicação e, segundo ela, confundiu a população com relação ao trabalho da ouvidoria da polícia. Antes da criação do disque-denúncia, sempre que era comunicado um crime à ouvidoria, a informação era repassada à polícia. Os responsáveis pela triagem das denúncias do disque-denúncia são comandados por um delegado de polícia e, naturalmente, quando chega alguma denúncia de crime cometido por policiais, esta não é repassada à ouvidoria.

\footnotetext{
${ }^{70}$ Depoimento dado ao autor a 10 de novembro de 2005.

${ }^{71}$ Ver mais adiante, página XXX.

72 O Instituto São Paulo Contra a Violência é uma organização não governamental, sem fins lucrativos, fundada em novembro de 1997 como resultado do Seminário São Paulo Sem Medo, com a missão de desenvolver políticas, programas e ações para reduzir a criminalidade e a violência, bem como aumentar a segurança dos cidadãos no estado de São Paulo.
} 
Irregularidades mais comuns em cada ouvidoria.

A comparação entre as denúncias mais comuns em cada ouvidoria esbarra na diversidade dos critérios adotados para classificá-las. Mesmo quando se quer avaliar a evolução das denúncias em uma ouvidoria específica ao longo do tempo, esta dificuldade aparece. Na ouvidoria da polícia de São Paulo, por exemplo, há mudanças constantes nos critérios de classificação das denúncias, que passaram de 13 em 1996 para $48 \mathrm{em} 2005 .^{73}$

Esta mudança constante dos critérios torna necessário reagrupá-los para poder comparar as ouvidorias. Nossa proposta é considerar três grandes grupos: as denúncias relativas ao emprego de violência por parte de policiais, aquelas relacionadas com atos de corrupção, e as que constituem algum tipo de irregularidade administrativa. ${ }^{74}$ Faz-se necessário ressaltar que nem sempre é possível identificar com clareza se a denúncia diz respeito ao emprego de violência, a um ato de corrupção ou a uma irregularidade administrativa. Como classificar, por exemplo, as denúncias rotuladas de "exercício arbitrário das próprias razões" que constam do relatório do ano de 2001 da Ouvidoria da Polícia do Rio Grande do Norte?

Para facilitar a apreciação dos dados assim obtidos, optamos por apresentá-los sob forma de gráficos. Faz-se necessário ressaltar que algumas ouvidorias não apresentam um volume suficiente de denúncias, ou estas não estão claramente identificadas para que seja possível classificá-las nas categorias propostas, ou ainda não dispomos de uma série temporal consistente, para que seja possível construir gráficos.

\footnotetext{
${ }^{73}$ Ver o ANEXO 3, no qual incluímos um quadro comparativo com a evolução dos critérios de avaliação das irregularidades na atividade policial na Ouvidoria da Polícia de São Paulo.

${ }^{74}$ O Relatório 1999-2001 da Ouvidoria da Justiça e da Segurança do Rio Grande do Sul faz uma classificação semelhante ao organizar as denúncias em quatro categorias (Violência de agentes da segurança pública, Corrupção de agentes da segurança pública, Irregularidades administrativas e disciplinares, e Outros). O Relatório de Atividades - 2004 da Ouvidoria da Secretaria da Segurança Pública da Bahia também classifica as denúncias em três grupos (Violência de agentes da segurança pública, Corrupção de agentes da segurança pública, e Irregularidades administrativas e disciplinares).
} 
Apresentamos a seguir os gráficos referentes às ouvidorias da polícia de São Paulo, Minas Gerais, Pará e Rio de Janeiro.

São Paulo:

\section{$\mathbf{N}^{\circ}$ de denúncias $\mathrm{PM}+\mathrm{PC}$ em SP}

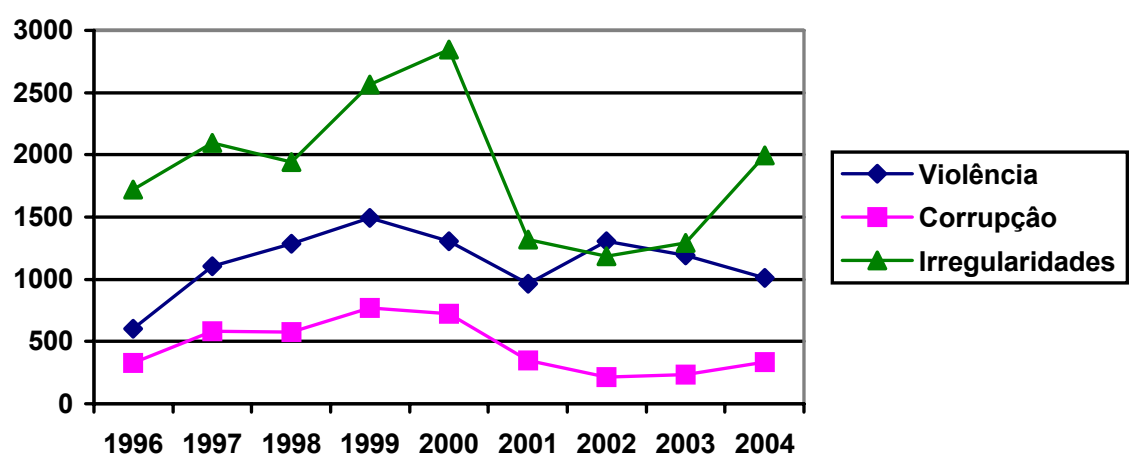

$N^{\circ}$ de denúncias PM em SP
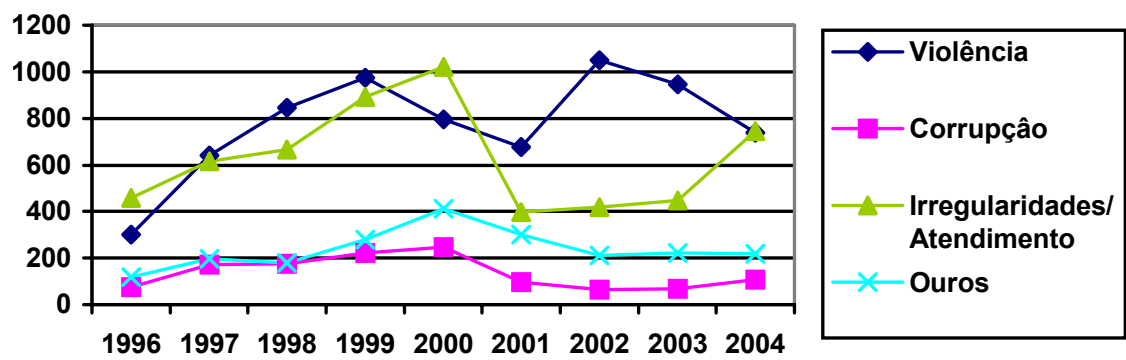
$N^{\circ}$ de denúncias $\mathrm{PC}$ em SP

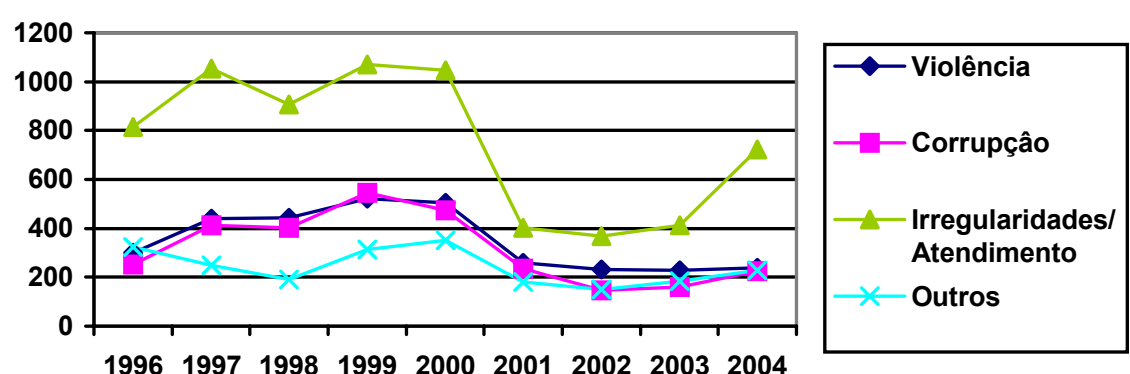

Violência SP

\section{Corrupção SP}
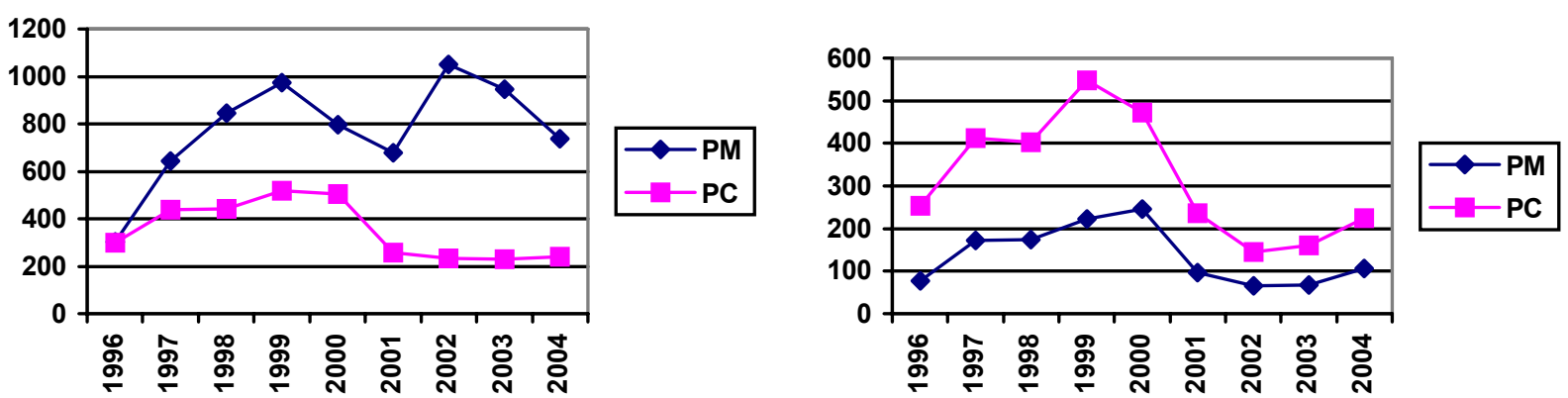

Irregularidades/Atendimento SP

Outros SP
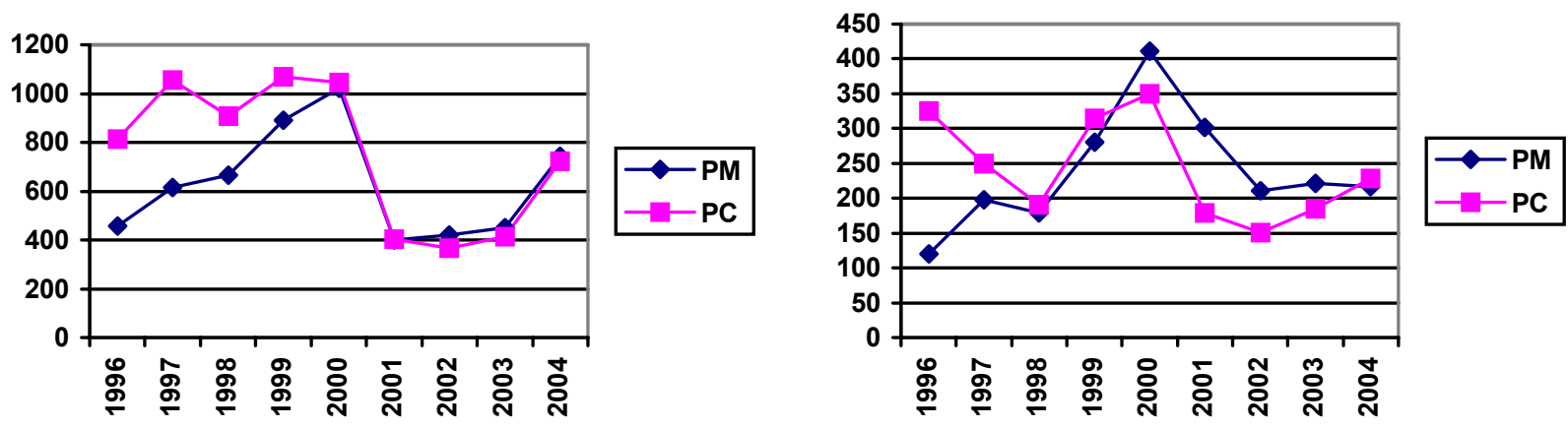
Minas Gerais:

№ de Denúncias PM em MG 2003-2005

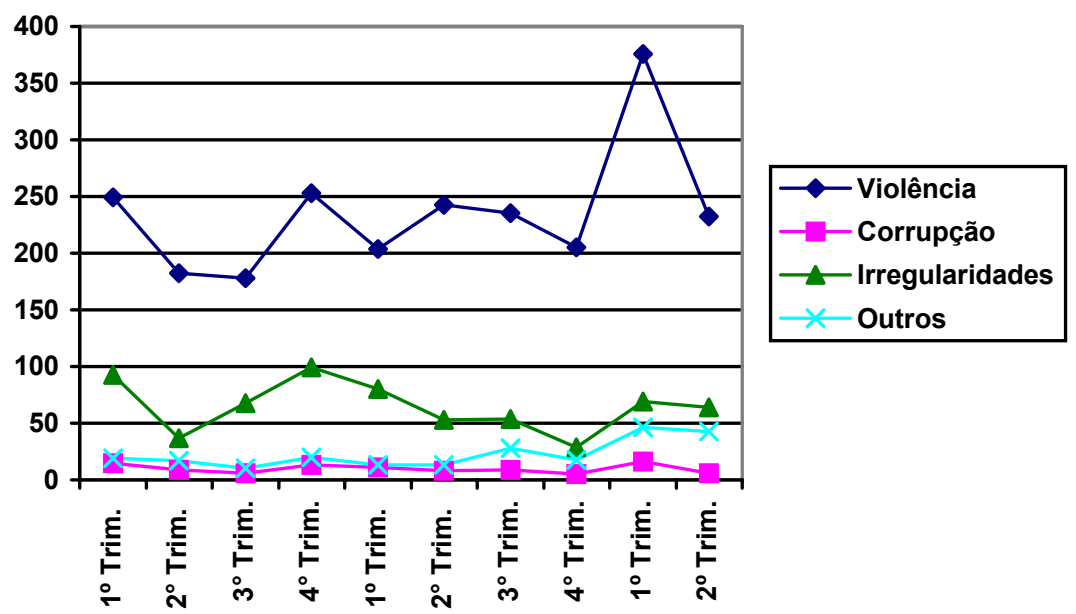

№ de Denúncias PC em MG 2003-2005

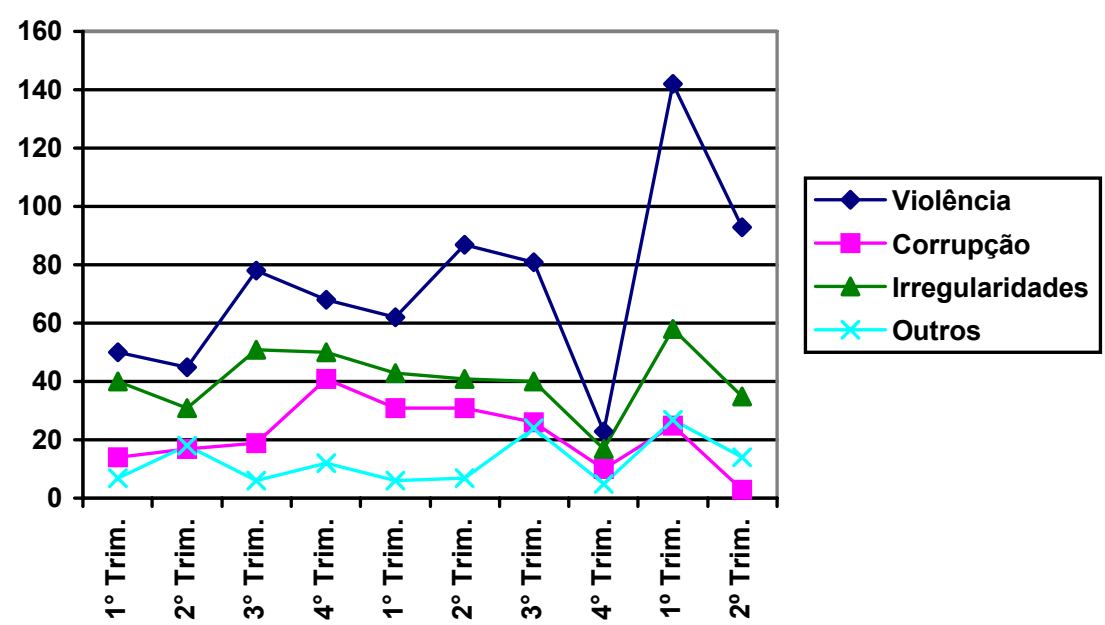




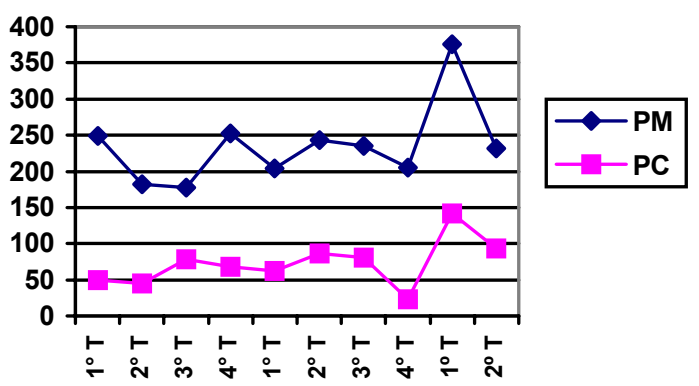

Irregularidades MG 2003-2005

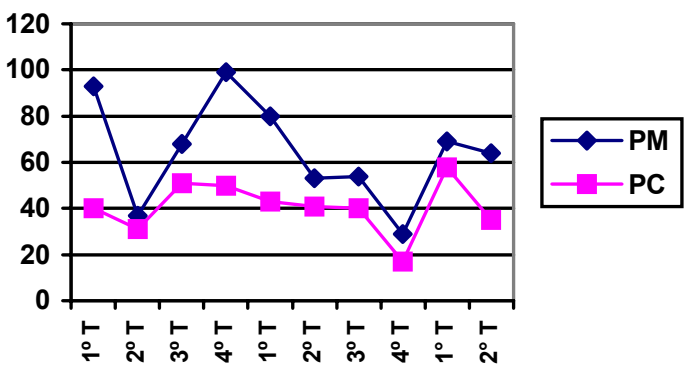

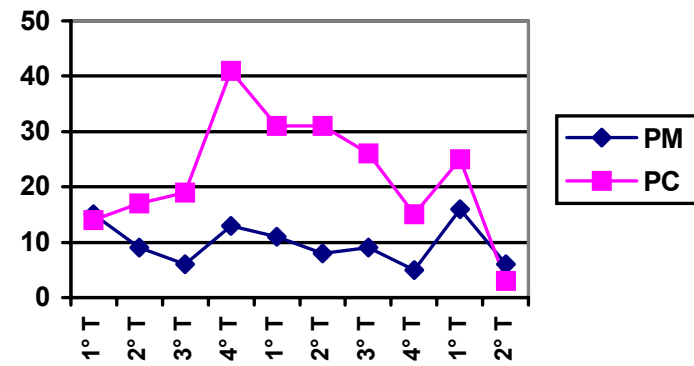

Outros MG 2003-2005

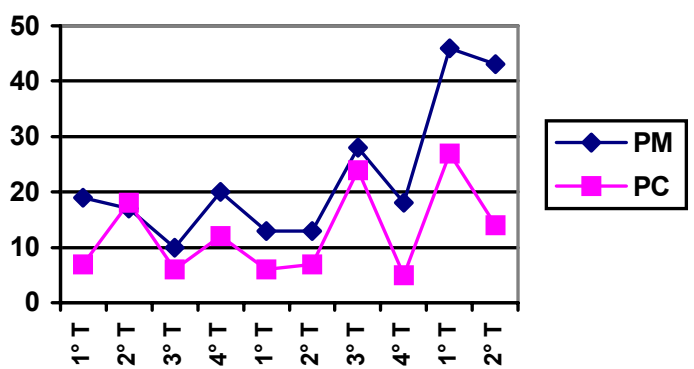

Pará:

№ de denúncias PM+PC no PA

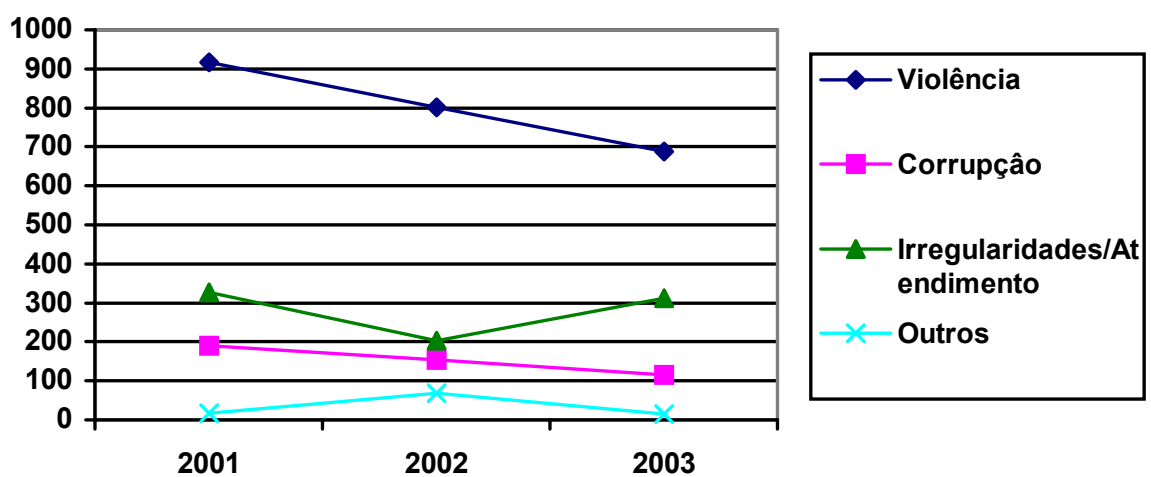


№ de denúncias PM no PA

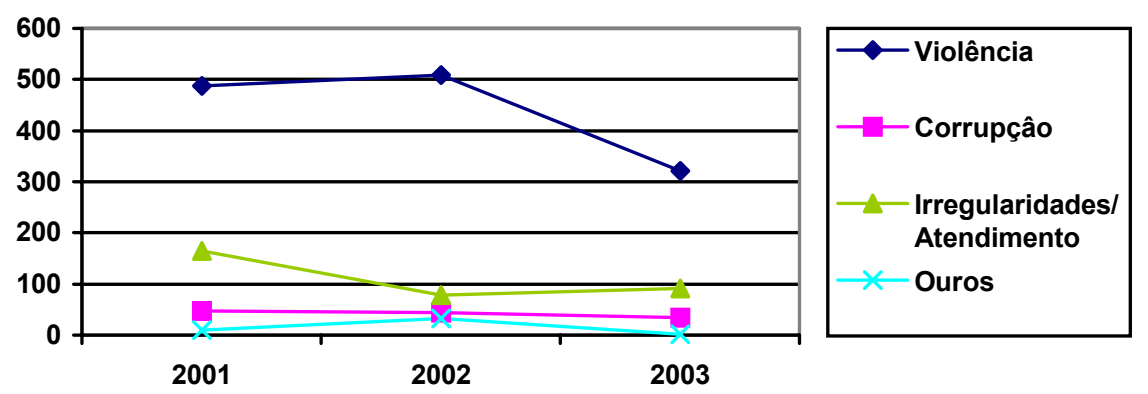

$N^{\circ}$ de denúncias PC no PA
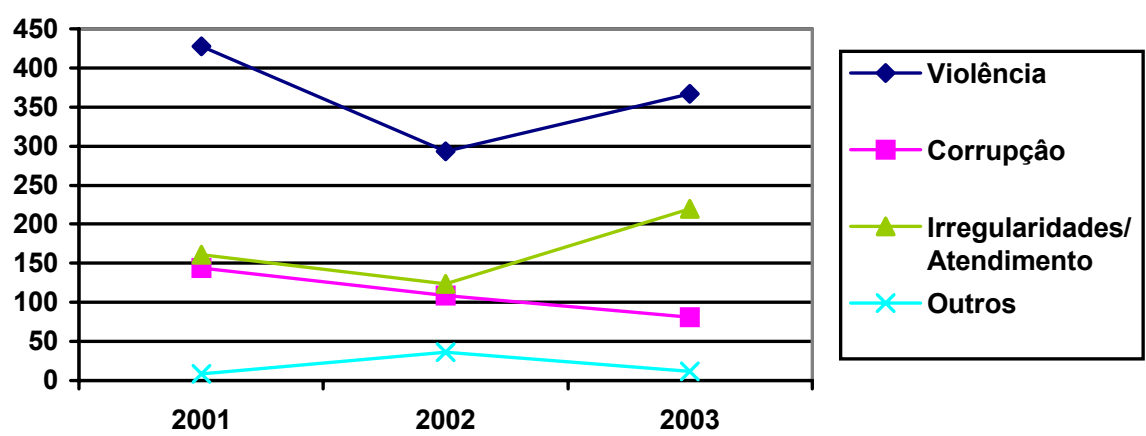

Violência PA

Corrupção PA
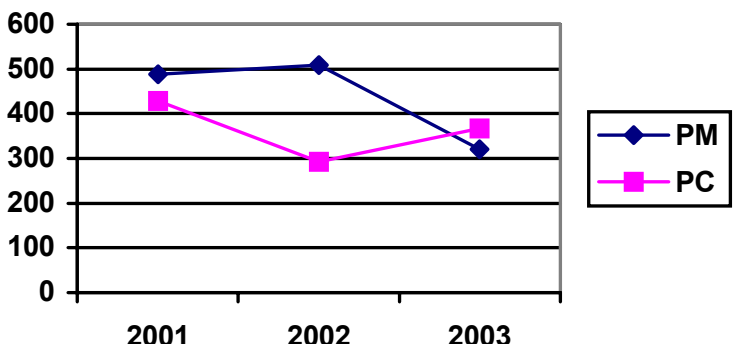

Irregularidades/Atendimento PA
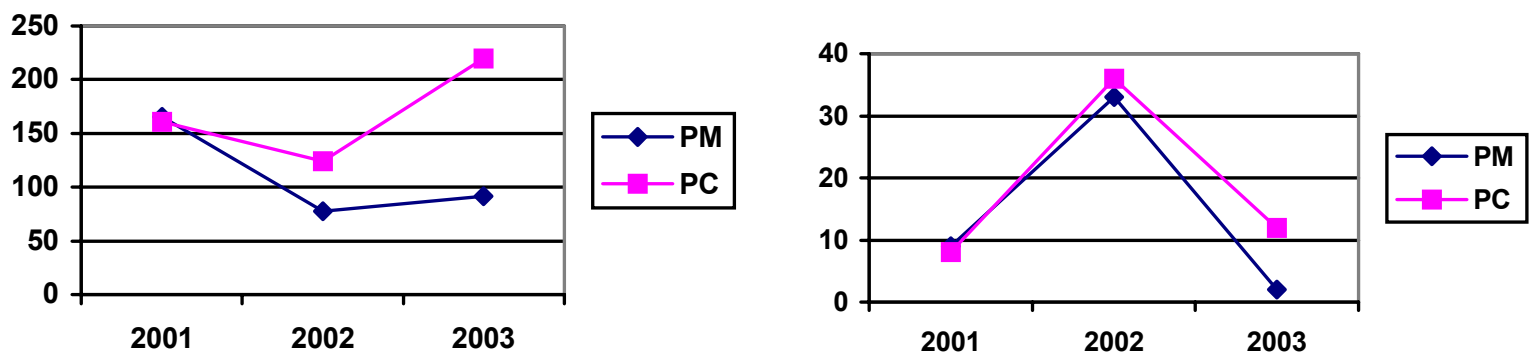
Rio de Janeiro:

Nº de Denúncias PM+PC no RJ 2004-2005

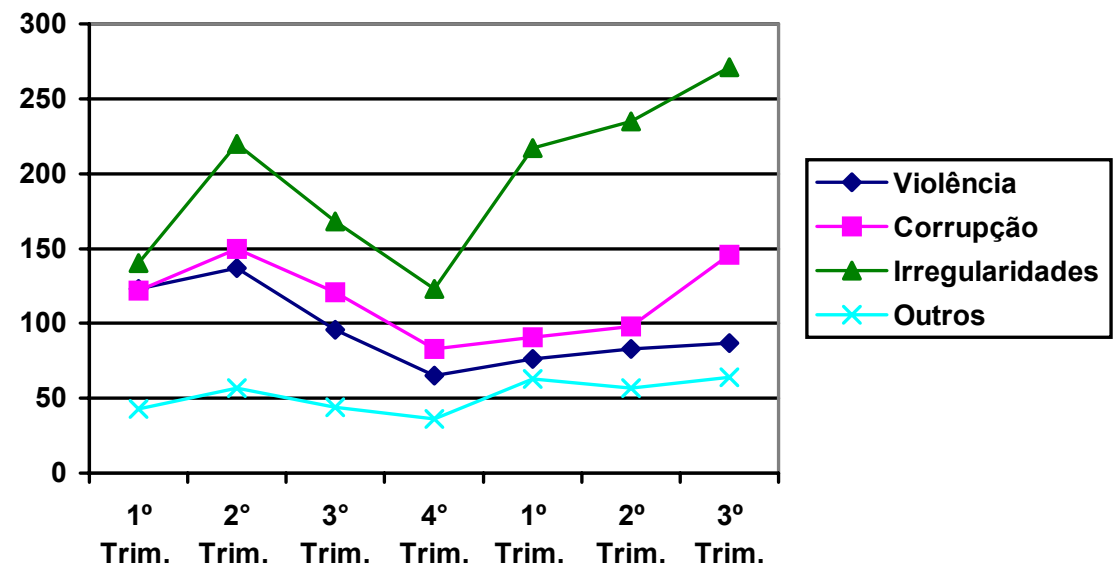

Nº de Denúncias PM no RJ 2004-2005

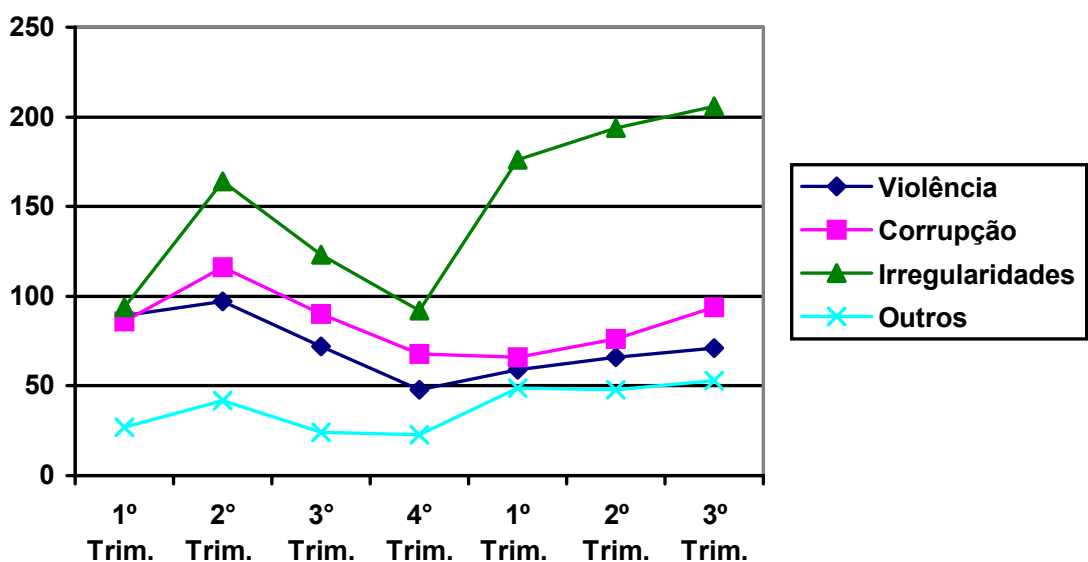




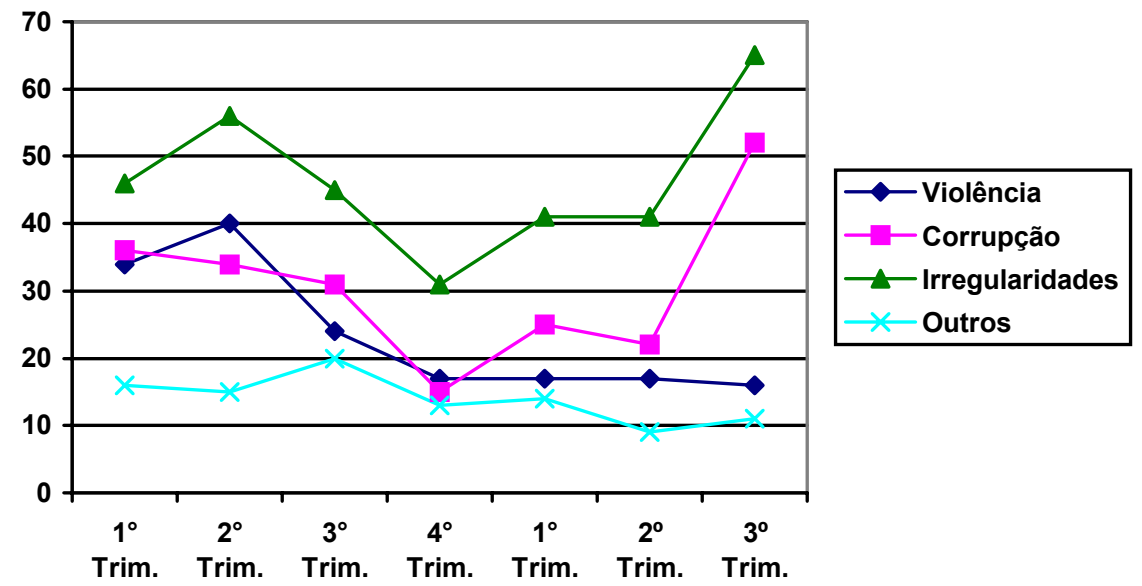

Violência RJ 2004-2005

Corrupção RJ 2004-2005
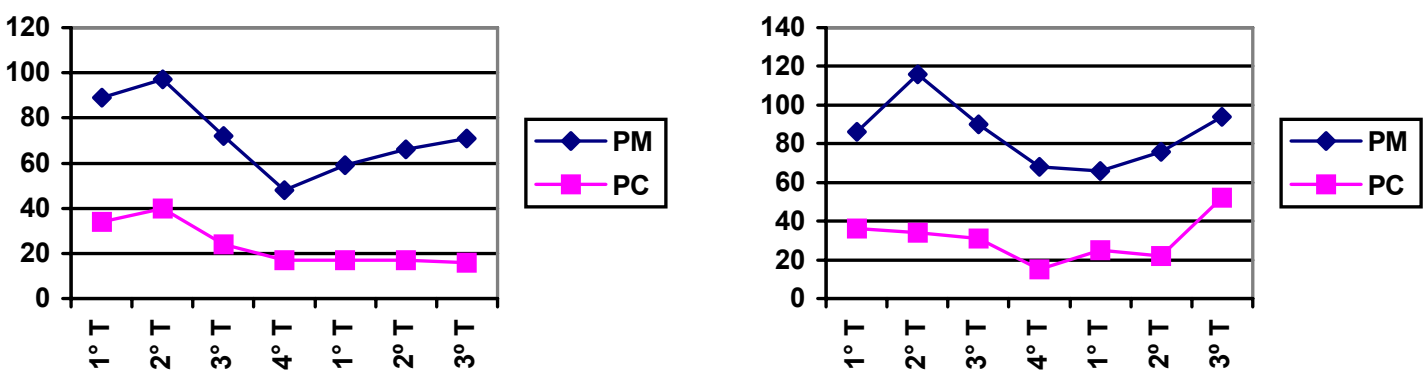

Irregularidades RJ 2004-2005

Outros RJ 2004-2005
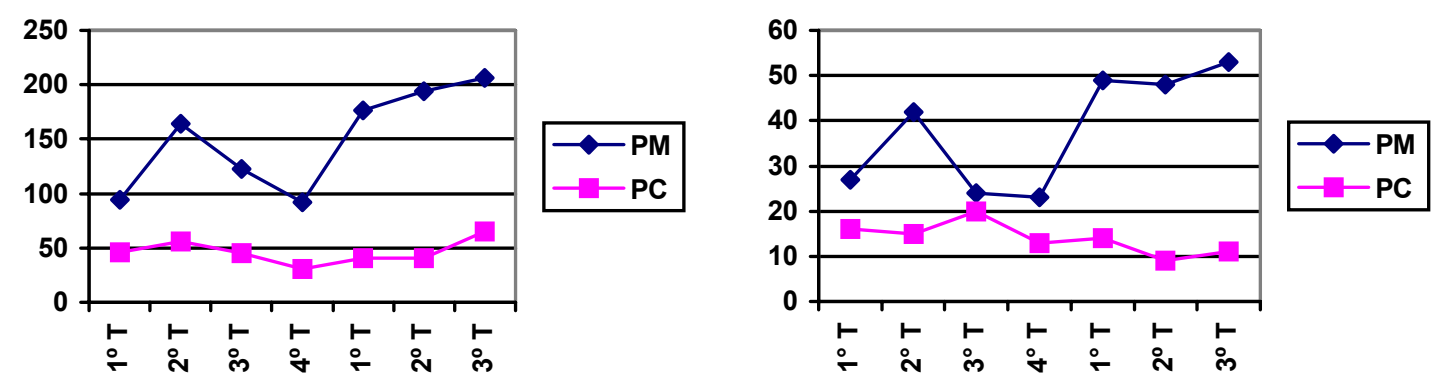

Rio Grande do Sul: 
Nº de denúncias RS 1999-2001

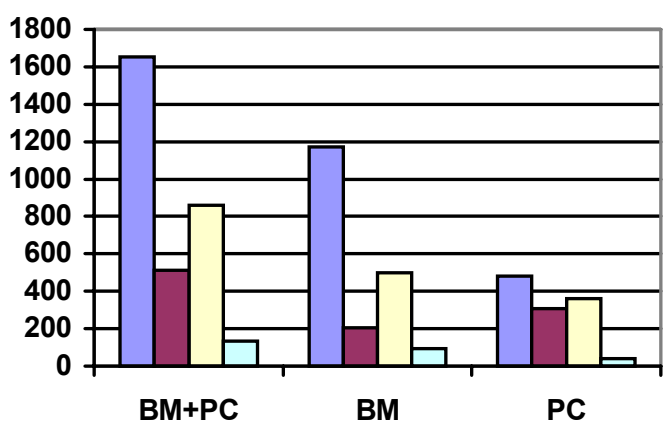

№ de denúncias RS 1999-2001

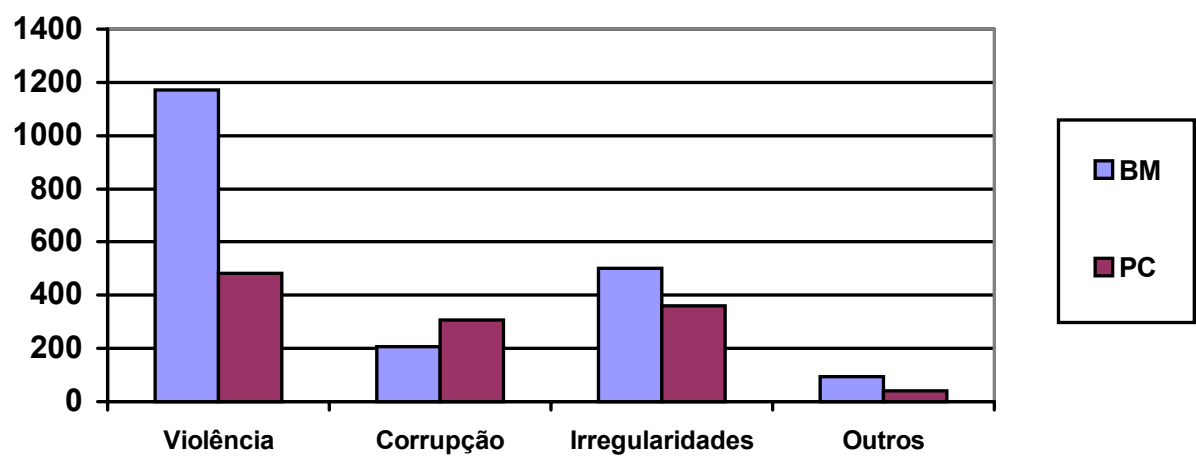

Nº de Denúncias BM+PC no RS 2003-2004

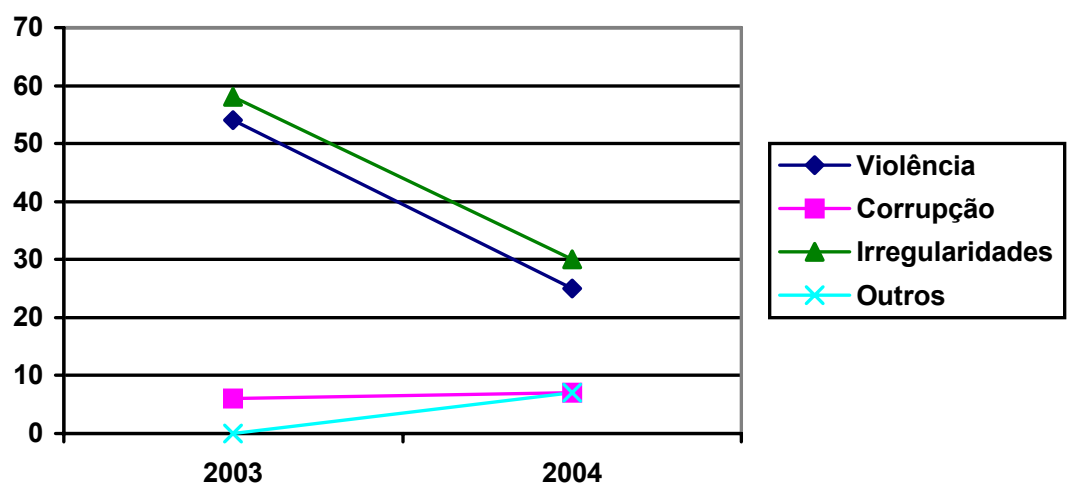


№ de Denúncias BM no RS 2003-2004

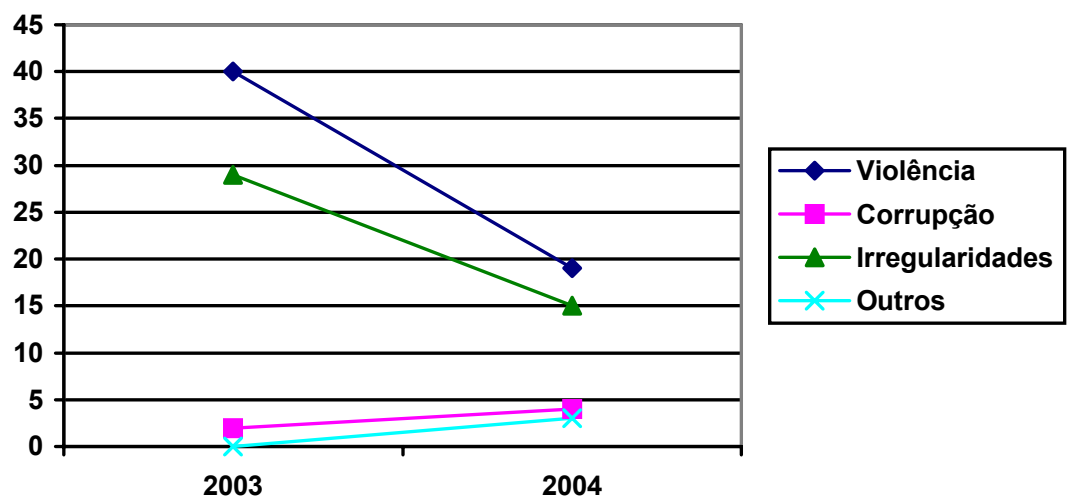

Nº de Denúncias PC no RS 2003-2004

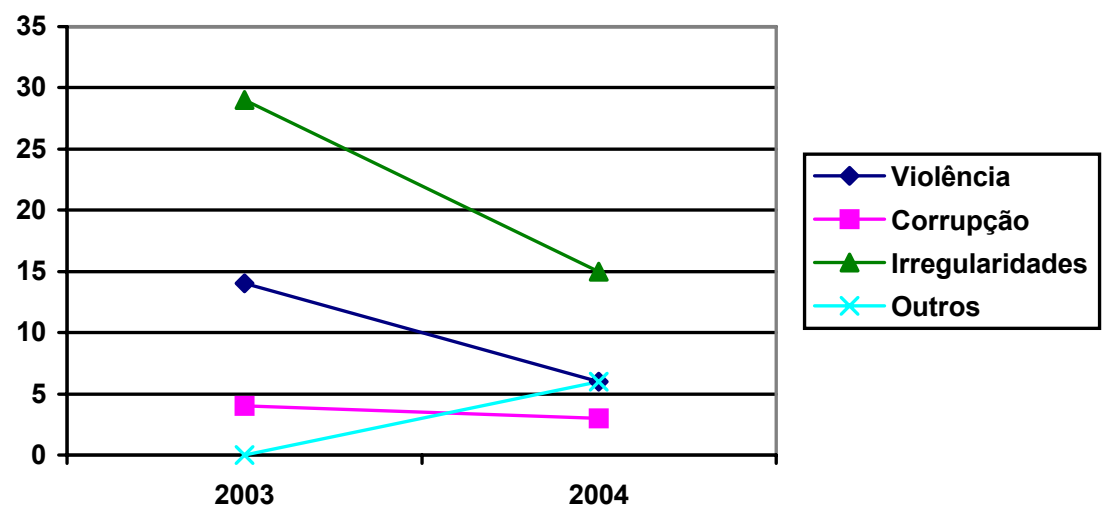

Violência RS 2003-2004

Corrupção RS 2003-2004
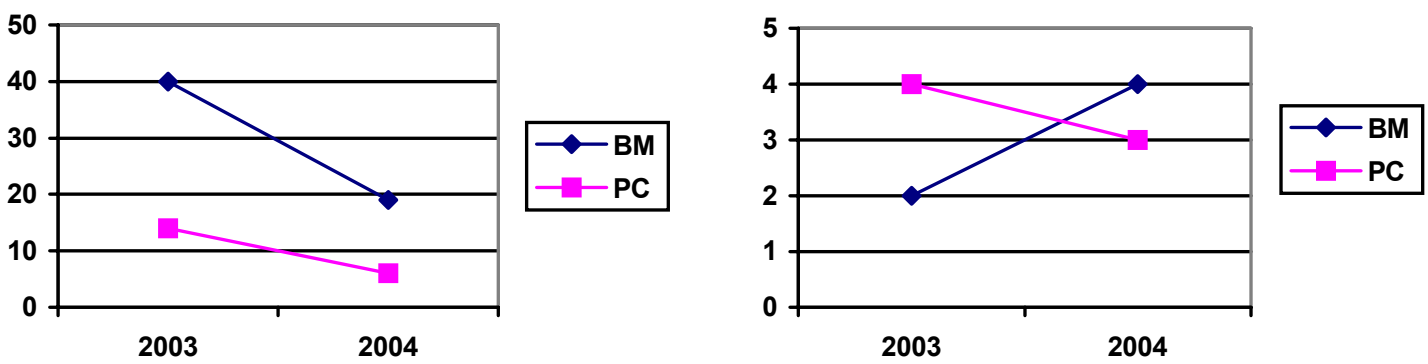

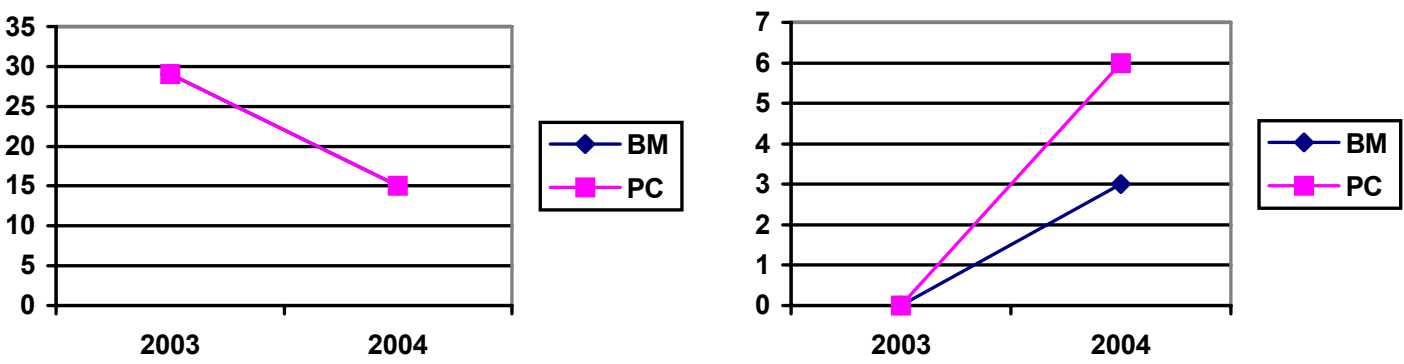

Bahia:

Nº de denúncias BA 2004

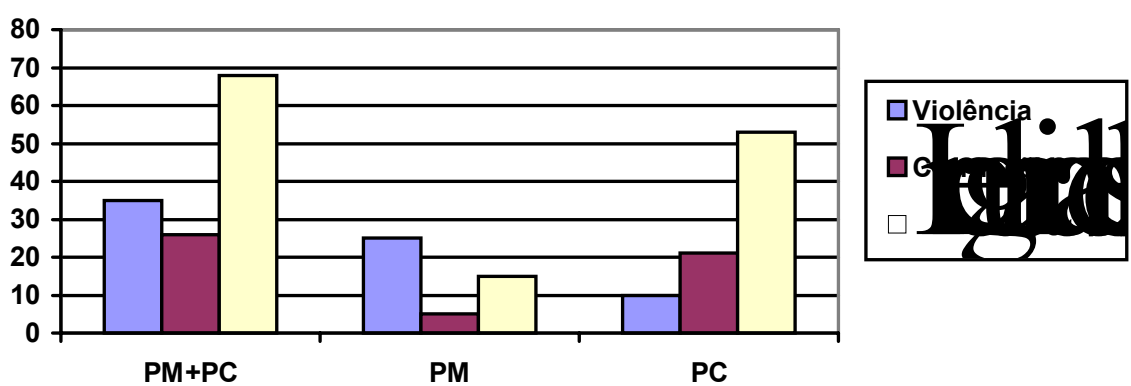

№ de denúncias BA 2004

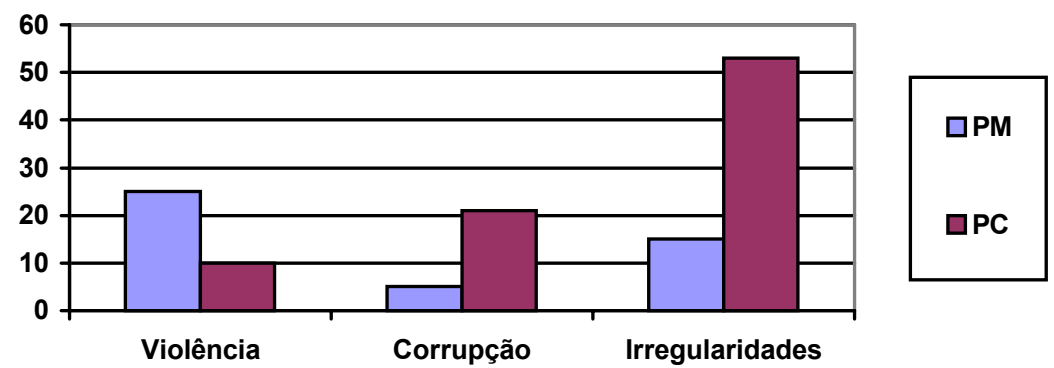

Rio Grande do Norte: 
№ de Denúncias PM+PC no RN 2001-2002

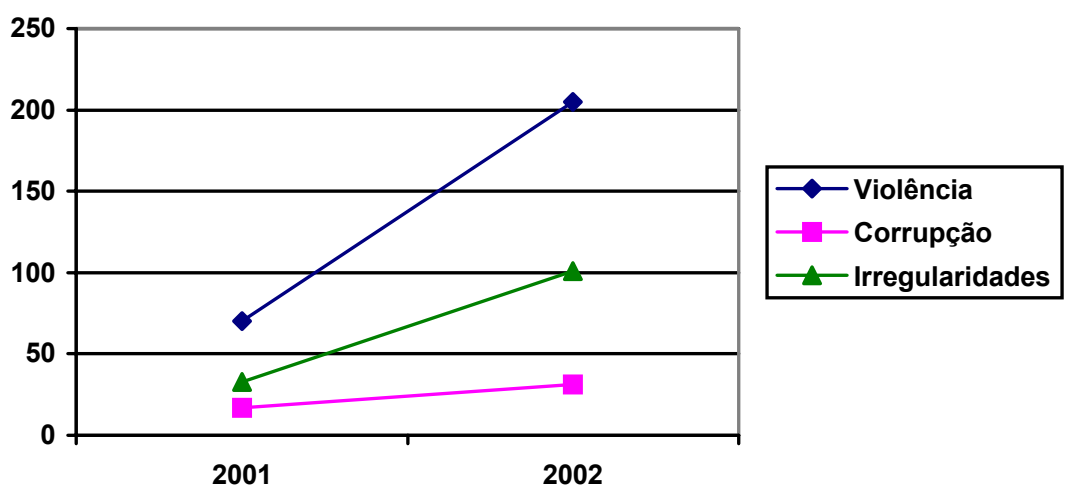

№ de Denúncias PM no RN 2001-2002

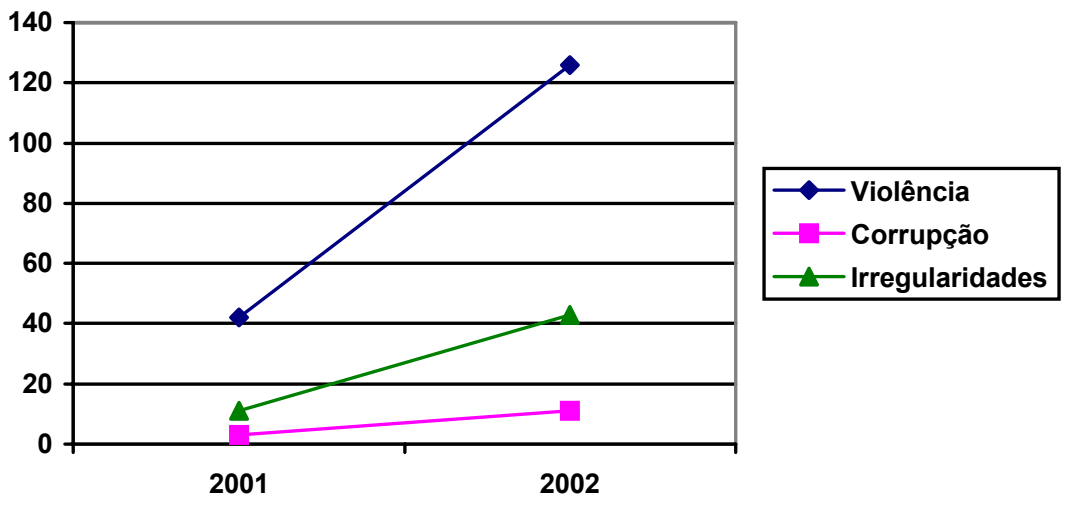

№ de Denúncias PC no RN 2001-2002

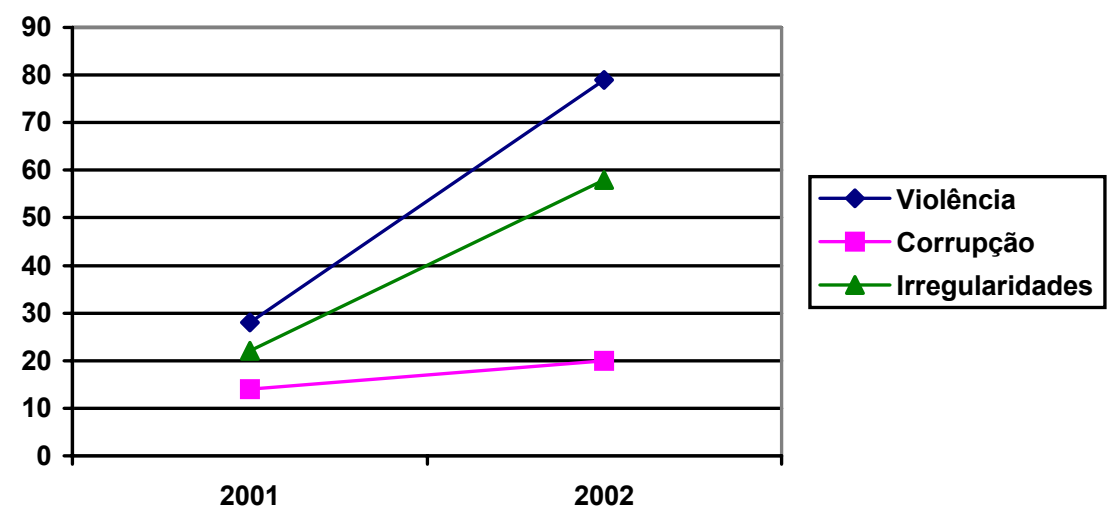



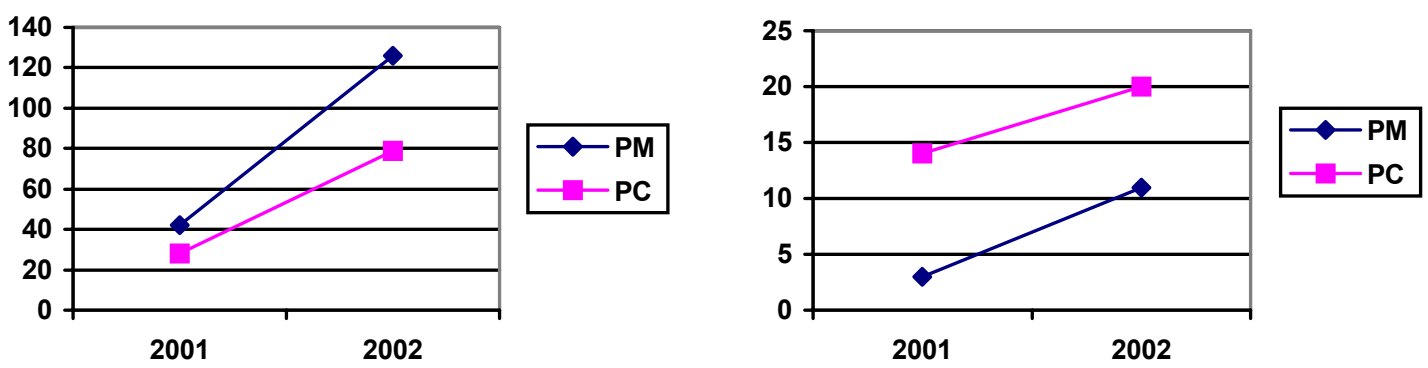

Irregularidades RN 2001-2002

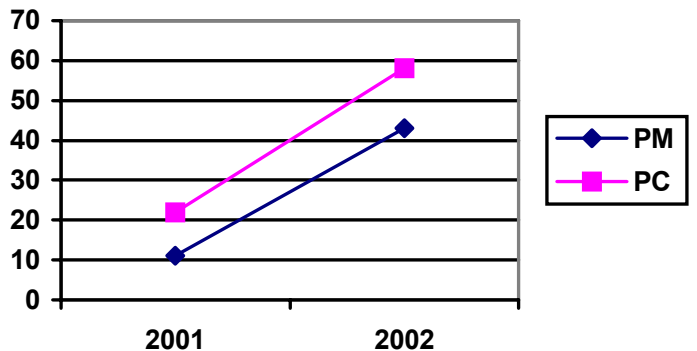

De uma maneira geral, há mais denúncias relacionadas ao emprego de violência do que a atos de corrupção. Verifica-se também que a Polícia Militar é apontada como mais violenta que a Polícia Civil, que, por sua vez, é denunciada como mais corrupta do que a primeira. Este resultado já era de certa forma previsível e pode ser explicado pelas atribuições e pela forma de atuação das duas corporações: a Polícia Militar tem uma função de policiamento preventivo e patrulhamento ostensivo, de modo que tende a se envolver com mais freqüência em situações de conflito. A Polícia Civil, por esse lado, desempenha o papel de polícia judiciária, e se concentra nas investigações, durante as quais já houve relatos de uso de tortura e de acertos em dinheiro pelo intermédio de advogados, como relatado em estudos anteriores. [Mingardi, 1992; Kant de Lima, 1995] O gráfico com o número de denúncias relativas à Polícia Civil em São Paulo $\left(\mathrm{N}^{\mathrm{o}}\right.$ de denúncias PC em SP) nos faz lembrar uma observação de Guaracy Mingardi que, no seu estudo sobre a polícia civil paulista, atribui o emprego de violência pelos policiais civis 
ao método de investigação, no qual a corrupção e a violência, principalmente a tortura, são utilizadas em conjunto.

Os gráficos anteriores foram construídos com números absolutos de denúncias. O tamanho das corporações policiais, contudo, não são iguais. Com efeito, em todos os estados brasileiros os efetivos da polícia militar são superiores aos da polícia civil, numa proporção aproximada de três policiais militares para cada policial civil, como pode ser verificado no quadro a seguir:

Efetivos das polícias em 2003

\begin{tabular}{|l|c|c|c|}
\hline Estado & Polícia Civil & Polícia Militar & PM/PC \\
\hline São Paulo & 32.623 & 79.812 & 2,45 \\
\hline Minas Gerais & 9.934 & 37.403 & 3,77 \\
\hline Pará & 2.542 & 11.705 & 4,60 \\
\hline Rio de Janeiro & 11.230 & 43.774 & 3,90 \\
\hline Rio Grande do Norte & 2.424 & 10.000 & 4,13 \\
\hline Rio Grande do Sul & 5.210 & 20.670 & 3,97 \\
\hline Bahia & 5.783 & 27.614 & 4,78 \\
\hline Brasil & 115.960 & 390.451 & 3,37 \\
\hline
\end{tabular}

Fonte: MJ/SENASP, dados atualizados a 17/08/2004

Podemos facilmente concluir, portanto, que os agentes da polícia civil cometem proporcionalmente mais irregularidades, sejam elas relativas ao emprego de violência ou a atos de corrupção, do que os policiais militares. Há duas maneiras de considerar esta questão. A partir do ponto de vista das forças policiais, podemos argumentar que a polícia militar é uma corporação mais disciplinada, na qual a hierarquia é mais respeitada e o comando tem mais autoridade. Na polícia civil, ao contrário, podemos encontrar vários grupos de poder relativamente autônomos que nem sempre se curvam ao comando central. A partir do pondo de vista do cidadão, contudo, o fato é que, 
independentemente do número de efetivos totais de cada corporação e da quantidade de irregularidades cometidas em proporção ao efetivo de cada uma delas, corremos muito mais riscos de sofrer algum tipo de ameaça ou violência por parte da polícia militar do que por parte da polícia civil. Com efeito, só entra em contato com a polícia civil quem procura uma delegacia ou está implicado em algum tipo de investigação, enquanto que basta circular pelas ruas para ter a oportunidade de encontrar uma viatura da polícia militar. Obviamente, dependendo do local e do horário, esta probabilidade aumenta muito, assim como os riscos, mas o que queremos ressaltar é que ninguém está a salvo de interagir com a polícia militar.

\section{Respostas das corporações e da corregedoria: desigualdade nas punições}

Ao voltar a nossa atenção para as conseqüências das denúncias nas ouvidorias, os resultados são controversos. Por um lado, verifica-se que parte das denúncias é investigada e que há punições. Pode-se argumentar, contudo, que as proporções de denúncias investigadas e de policiais efetivamente punidos são insatisfatórias, principalmente quando se considera que as denúncias recebidas pela ouvidoria e incluídas nos relatórios já são filtradas pela equipe da ouvidoria. Com efeito, para que uma denúncia possa ser encaminhada para as instâncias de investigação interna das polícias, ela precisa apresentar um mínimo de detalhamento que possibilite a identificação dos policiais envolvidos. O que mais chama a atenção, contudo, é a desigualdade de tratamento quando se trata de uma denúncia relativa a um oficial de patente superior ou a um delegado, em comparação com praças ou agentes policiais, como pode ser comprovado nos quadros a seguir. 


\section{Policiais Militares Denunciados e Punidos a Partir de Denúncias na Ouvidoria da Polícia de São Paulo - 1998/2003}

\begin{tabular}{|c|c|c|c|}
\hline Patente & $\begin{array}{c}\text { Denunciados na } \\
\text { Ouvidoria }\end{array}$ & $\begin{array}{c}\text { Policiais } \\
\text { investigados (\%) }\end{array}$ & $\begin{array}{c}\text { Policiais Punidos } \\
\text { (\%) }\end{array}$ \\
\hline Oficiais Superiores & 311 & 1,3 & 0,3 \\
\hline Coronel & 163 & 11,0 & 4,9 \\
\hline Tenente Coronel & 262 & 8,0 & 5,0 \\
\hline Major & $\mathbf{7 3 6}$ & $\mathbf{5 , 8}$ & $\mathbf{3 , 0}$ \\
\hline Sub total & & & 3,5 \\
\hline Oficiais intermediários & 828 & 9,4 & 12,6 \\
\hline Capitão & 1144 & 21,9 & 38,1 \\
\hline Tenente & 42 & 59,5 & $\mathbf{9 , 4}$ \\
\hline Aspirante & $\mathbf{2 0 1 4}$ & $\mathbf{1 7 , 5}$ & 14,9 \\
\hline Sub total & & & 20,2 \\
\hline Praças & 67 & 31,3 & 28,7 \\
\hline Sub Tenente & 1818 & 30,0 & 32,5 \\
\hline Sargento & 1122 & 39,8 & $\mathbf{2 9 , 2}$ \\
\hline Cabo & 5332 & 46,2 & $\mathbf{2 3 , 8}$ \\
\hline Soldado & $\mathbf{8 3 3 9}$ & $\mathbf{4 1 , 7}$ & \\
\hline Sub total & $\mathbf{1 1 0 8 9}$ & $\mathbf{3 4 , 9}$ & \\
\hline Total & \multicolumn{2}{|c|}{} \\
\hline & & & \\
\hline
\end{tabular}

Observa-se que quando se caminha das patentes mais altas para as mais baixas, tanto o índice de investigação quanto o de punição aumentam. Na polícia militar, por exemplo, os oficiais superiores punidos representam apenas 3\% dos denunciados na ouvidoria, enquanto que quase um terço dos praças denunciados são punidos. Nos dois extremos esta distância é ainda mais acentuada:

dos 311 coronéis denunciados na ouvidoria, apenas 4 foram investigados e um único deles foi punido;

- $\quad$ dos 8.339 soldados denunciados, um pouco menos da metade (2.463 ou $46,2 \%)$ foram investigados e quase um terço $(1.733$ ou $32,5 \%)$ foram punidos.

A mesma desigualdade no número de policiais investigados e nas punições se repete na polícia civil, como mostra o quadro a seguir. 
Policiais Civis Denunciados e Punidos a Partir de Denúncias na Ouvidoria da Polícia de São Paulo - 1998/2003

\begin{tabular}{|c|c|c|c|}
\hline Cargo & $\begin{array}{c}\text { Denunciados na } \\
\text { Ouvidoria }\end{array}$ & $\begin{array}{c}\text { Policiais } \\
\text { investigados (\%) }\end{array}$ & $\begin{array}{c}\text { Policiais Punidos } \\
\mathbf{( \% )}\end{array}$ \\
\hline Delegado & 2602 & 8,4 & 2,9 \\
\hline Médico Legista & 7 & 71,4 & 14,3 \\
\hline Investigador & 2407 & 24,2 & 12,9 \\
\hline Carcereiro & 410 & 39,3 & 18,8 \\
\hline Escrivão & 496 & 15,1 & 7,3 \\
\hline Agente Policial & 129 & 96,1 & 50,4 \\
\hline Agente de & 28 & 21,4 & 10,7 \\
Telecomunicações & & 0 & 0 \\
\hline Chefe de Cartório & 3 & 0 & 0 \\
\hline Datiloscopista & 1 & 50,0 & 0 \\
\hline Fotógrafo Técnico & 4 & & 37,5 \\
\hline Policial & 8 & 62,5 & 27,3 \\
\hline Papiloscopista & 22 & 86,4 & $\mathbf{9 , 4}$ \\
\hline Perito Criminal & $\mathbf{6 1 1 7}$ & $\mathbf{1 9 , 6}$ & \\
\hline Total & \multicolumn{2}{|c}{}
\end{tabular}

A diferença de tratamento entre soldados e coronéis se repete, agora entre delegados e agentes policiais. Enquanto que apenas $8,4 \%$ dos delegados denunciados foram investigados e $2,9 \%$ deles punidos, $96,1 \%$ dos agentes policiais denunciados foram investigados e $50,4 \%$ deles punidos.

Esses dados corroboram os resultados de uma pesquisa qualitativa realizada pela equipe do Centro de Estudos de Segurança e Cidadania (Cesec), em 2000 e 2001, que revela uma reclamação recorrente da parte de policiais de graus hierárquicos inferiores, no sentido de que os mecanismos disciplinares são acionados preferencialmente contra as bases, e não contra as cúpulas das corporações, garantindo maior impunidade para delegados e oficiais. [Lemgruber, Musumeci e Cano, 2003] 


\section{Perfil dos denunciantes}

Vários relatórios de atividades das ouvidorias de polícia incluem um perfil dos denunciantes construído a partir de categorias como gênero, idade, raça, parentesco com a vítima, grau de instrução, situação de trabalho, renda familiar. Todo cuidado é pouco na análise desses dados, pois eles se referem principalmente aos denunciantes que compareceram pessoalmente à ouvidoria e foram atendidos pela assessoria social, e estes constituem uma minoria. Na ouvidoria da polícia de São Paulo, por exemplo, das 4877 denúncias encaminhadas no ano de 2000, apenas 475 foram recebidas pessoalmente na ouvidoria. O relatório relativo ao primeiro trimestre de 2002 , também da ouvidoria de São Paulo, revela que apenas 3,6\% das 490 denúncias foram feitas pessoalmente. Essa queda significativa na proporção de pessoas que procuram pessoalmente a ouvidoria provavelmente está relacionada com a sua mudança de endereço, ocorrida em 2001.

Até onde pudemos perceber, as características mais marcantes do perfil dos denunciantes que procuram as ouvidorias são o gênero e o grau de instrução. Com efeito, cerca de $75 \%$ dos denunciantes são homens, e os cidadãos que procuram a ouvidoria com segundo grau ou curso superior estão nitidamente super-representados (50 a 65\%) quando comparados com a média nacional. Para servir de termo de comparação, apenas um quarto dos eleitores brasileiros possui segundo grau ou curso superior segundo os dados do Tribunal Superior Eleitoral. Seria interessante, contudo, comparar o perfil dos denunciantes na ouvidoria com o público que procura as outras instâncias de reclamação, como as promotorias e as corregedorias, para verificar se o fato de as ouvidorias trabalharem de maneira mais informal faz com que a população mais simples prefira, de fato, utilizar as ouvidorias como canal de comunicação. 
O Relatório Anual de Prestação de Contas 2000 da ouvidoria da polícia de São Paulo contém dados interessantes relativos ao perfil dos denunciantes, pois permite cruzar as informações relativas à natureza das denúncias com o grau de instrução dos denunciantes. Um dado que chama a atenção é que mais de dois terços das denúncias se referem a atos de violência, enquanto que as denúncias relativas à corrupção representam apenas um décimo do total. Uma possível explicação é que atos de violência causam mais indignação e o denunciante tem mais determinação para comparecer pessoalmente à ouvidoria do que quando a queixa é de corrupção. Outro resultado interessante é que, à medida que aumenta o grau de instrução, diminui um pouco a proporção de denúncias de atos de violência e aumenta significativamente a quantidade de denúncias sobre irregularidades administrativas, talvez devido à dificuldade para pessoas mais simples de perceber que irregularidades administrativas também são passíveis de denúncia.

Perfil dos Denunciantes SP 2000 - Natureza das denúncias por Grau de Instrução

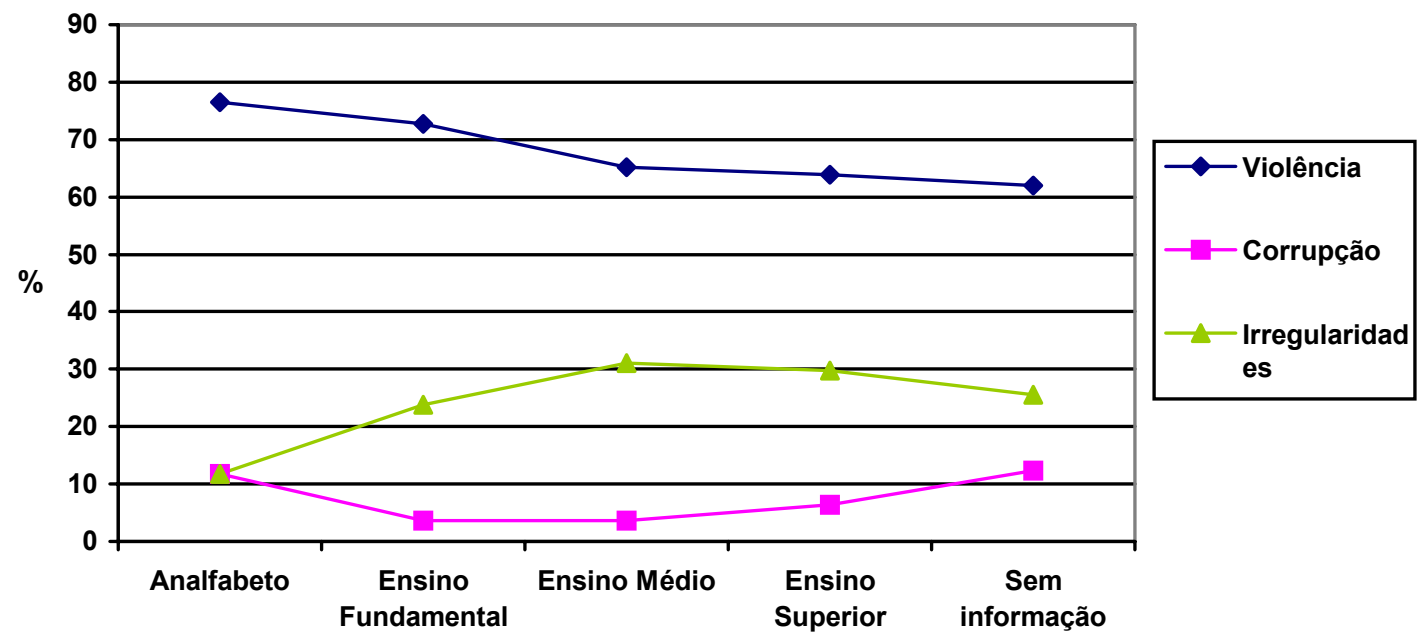

Outro dado interessante, contido no mesmo relatório, é que $10,15 \%$ dos denunciantes que compareceram pessoalmente à ouvidoria são policiais militares e 
$1,52 \%$ são policiais civis. De maneira semelhante, o relatório de atividades relativo ao ano de 2003 da ouvidoria de Minas Gerais indica que, dos denunciantes que compareceram pessoalmente à ouvidoria e que tiveram suas ocupações registradas, 6,71\% são policiais militares e 3,14\% são policiais civis. Na ouvidoria do Rio Grande do Sul, os números são de 14,92\% para os policiais militares, correspondendo à maior categoria profissional registrada, e 1,33\% para os policiais civis, no período 1999-2001. Estes dados comprovam o testemunho de vários ouvidores que afirmam que, se no início foi difícil lidar com as corporações policiais, e alguns foram até ameaçados de represálias, com o tempo as ouvidorias foram ganhando algum reconhecimento junto aos policiais, principalmente os de cargos subalternos que passaram a procurar a ouvidoria para denunciar truculência ou irregularidades cometidas por superiores. Naturalmente, os policiais que procuram as ouvidorias não são bem vistos por seus pares e, algumas vezes, são repreendidos por seus superiores. Esta questão foi discutida na $4^{\mathrm{a}}$ Reunião do Fórum Nacional de Ouvidores da Polícia, realizada nos dias $1^{\mathrm{o}}$ e 2 de outubro em Brasília. ${ }^{75}$ Naquela ocasião, o ouvidor da polícia do Rio Grande do Sul, Jayme Eduardo Machado, mencionou as dificuldades encontradas ao lidar com denúncias de policiais militares contra seus chefes hierárquicos e o seu colega de Minas Gerais, José Francisco da Silva, citou um caso ocorrido no seu estado de um policial que fez uma denúncia contra seu superior e acabou sendo processado, numa total inversão de valores por força do corporativismo. De uma maneira geral, os policiais militares são punidos pelo simples fato de procurar a ouvidoria sem a autorização do superior hierárquico. No Rio Grande do Sul, há uma lei que autoriza os policiais militares a procurar a ouvidoria, mas esta não pode impedir o constrangimento e a aplicação de punição ao policial denunciante. Além disso, os superiores hierárquicos

\footnotetext{
${ }^{75}$ Conforme relatado na ata da reunião.
} 
têm várias maneiras de aplicar "punições brancas" aos seus subalternos com manipulações das escalas de trabalho e dos plantões.

Acrescente-se, ainda, a explicação segundo a qual a grande quantidade de policiais que procuram a ouvidoria de seu estado acontece porque o policial também é cidadão que tem família, parentes, amigos expostos ao arbítrio policial. [Rothe, 2004]

\section{Descrição de casos representativos}

Alguns relatórios de atividades das ouvidorias incluem casos representativos que são muito interessantes para ilustrar a forma de atuação da polícia e o procedimento de abordagem dos cidadãos.

O relato a seguir é um exemplo de caso prioritário incluído no relatório anual de prestação de contas da Ouvidoria da Polícia de São Paulo para o ano de 1996. Trata-se de um episódio que envolve três forças policiais diferentes, Guarda Civil Municipal, Polícia Militar e Polícia Civil. Ilustra várias irregularidades praticadas pelos policiais e mostra que, segundo Caco Barcelos [Barcelos, 1992], ninguém está a salvo da ROTA, cujo método de abordagem consiste em "atirar primeiro, perguntar depois":

DATA DOS FATOS: 6 DE OUTUBRO DE 1995

DATA DA DENÚNCIA NA OUVIDORIA: 4 DE MARÇO DE 1996

VÍTIMAS: P.C.F. e M.A.A.

FATOS: As vítimas, guardas civis metropolitanos, trabalhavam como seguranças de uma agência bancária nos dias de folga. Na data referida, abordaram dois menores, suspeitando que pretendiam assaltar clientes que saíam da agência. Levaram os menores para o interior de uma oficina mecânica para revistá-los, quando chegou uma viatura da ROTA. Os policiais militares haviam recebido de um transeunte a notícia de que ali estava ocorrendo um assalto. Logo que entraram na oficina, efetuaram disparos na direção dos guardas e dos menores. Os dois guardas civis morreram. Três policiais militares foram presos em flagrante pela Polícia Civil, mas logo libertados pelo juiz-auditor do Tribunal de Justiça Militar. 
PROVIDÊNCIAS TOMADAS: A Ouvidoria da Polícia encaminhou ofício ao Corregedor da Polícia Militar, solicitando informações acerca das providências tomadas. Veio a notícia de instauração de Inquérito Policial Militar, posteriormente remetido ao Tribunal de Justiça Militar. Foi requisitada, pelo Ministério Público da 2a Auditoria, a realização de "reconstituição".

ANDAMENTO: Em 27/08/96, os autos foram remetidos à Justiça Comum, em cumprimento ao disposto na Lei $n^{0}$ 9.299/96. Os autos tramitam perante a $3^{\text {a }}$ Vara do Júri, do Fórum Regional de Santo Amaro, sob o $\mathrm{n}^{\mathrm{o}} 1.073 / 95$. O representante do Ministério Público solicitou novas diligências e os autos retornaram à origem em 17.10.96.

Outro relato que mostra o despreparo de alguns policiais para lidar com situações aparentemente corriqueiras:

DATA DOS FATOS: 04 DE SETEMBRO DE 2001

DATA DA DENÚNCIA NA OUVIDORIA: 05 DE SETEMBRO DE 2001 DENUNCIANTE: EX OFFICIO

VÍTIMAS: S.L.A.

FATOS: caso rumoroso, de repercussão nacional: policiais militares realizaram intensa perseguição por ruas da zona sul da Capital a um perueiro que teria furado um bloqueio de trânsito para apreender veículos ilegais. A vítima se refugiou na casa da família e se escondeu debaixo da cama, tendo sido executada impiedosamente, na frente de familiares, com tiros de metralhadora.

PROVIDÊNCIAS TOMADAS: a ouvidoria oficiou imediatamente ao DECAP e à CORREGPM, tendo sido instaurados Inquérito Policial e Inquérito Policial Militar para apuração do crime praticado. Os dois policiais militares envolvidos foram recolhidos ao presídio da Polícia Militar.

Aliás, a prática de "atirar primeiro, perguntar depois" parece ser empregada com certa freqüência, colocando em perigo a vida de cidadãos inocentes que têm o azar de se encontrar no caminho entre os policiais e os suspeitos:

DATA DOS FATOS: 13 DE NOVEMBRO DE 2001

DATA DA DENÚNCIA NA OUVIDORIA: 16 DE NOVEMBRO DE 2001

DENUNCIANTE: EX OFFICIO

VÍTIMAS: A.G.R.

FATOS: Policiais Militares realizavam uma blitz na Capital e iniciaram perseguição a um motoqueiro, que fugiu da averiguação por estar sem habilitação naquele momento. O motoqueiro refugiou-se numa padaria próxima, onde trabalhava como entregador. Segundo testemunhas, os policiais já 
desceram da viatura atirando na direção do estabelecimento. Um dos tiros atingiu uma jovem de 16 anos, que estava no local comprando doces.

PROVIDENNCIAS ADOTADAS: a Ouvidoria solicitou providências à CORREGPM e ao DECAP, e aguarda a conclusão das apurações. De acordo com informações obtidas, três policiais foram indiciados por homicídio culposo e tentativa de homicídio e foram recolhidos ao Presídio da Polícia Militar.

Como mencionado anteriormente, as ouvidorias de polícia recebem também denúncias dos próprios integrantes das corporações policiais, na maioria das vezes, contra superiores hierárquicos, como mostra o seguinte relato, incluído na seção "casos exemplares" do Relatório de Atividades 1999-2001 da Ouvidoria da Justiça e da Segurança do Rio Grande do Sul:

Protocolo: $32 / 00$

Data do fato: maio 1999

Data da denúncia: $14 / 01 / 00$

Contato: Pessoalmente

Local dos fatos: São Borja

Órgão: Brigada Militar

Denunciante: a própria vítima

Vítima: A

Histórico: A vítima, que é policial militar, comunicou à Ouvidoria que, desde maio de 1999, tem sido perseguida pelo Major X, por ser negro. Declarou que, por diversas vezes, sofreu discriminação e foi humilhado em público, sendo chamado de "negro incompetente", "negro sujo" ou ouvido o major dizer-lhe: "tu és preto, mas és gente, tens que aprender a trabalhar". Foi registrada ocorrência na polícia civil, contra o major, por calúnia difamação e racismo. Também foi instaurado IPM sobre os fatos, que concluiu pela existência de indícios de crime comum, de crime militar e de transgressão disciplinar, por parte do major, e também de crime militar e transgressão da disciplina por parte do denunciante. Porém, na solução do IPM, o coronel Y discordou, em parte, das conclusões do encarregado do procedimento, entendendo que o IPM não logrou comprovar a existência de indícios de crime ou transgressão disciplinar por parte do major e sim indícios de crime militar e transgressão da disciplina por parte do soldado denunciante. $\mathrm{O}$ denunciante sentiu-se injustiçado, ferido em sua dignidade e pediu providências.

Providências tomadas: A Ouvidoria tomou o depoimento da vítima e solicitou informações à Delegacia de São Borja e à Justiça Militar de Santa Maria (JME), para onde fora remetido o IPM. A DP de São Borja informou que as ocorrências registradas pelo denunciante foram remetidas ao Comando da $\mathrm{BM}$, em Livramento, em razão da competência. O Promotor de Justiça, junto à JME, entendeu haver indícios de crime militar e ofereceu denúncia contra o major $\mathrm{X}$ 
pelo crime previsto no art. 174, do CPM, rigor excessivo. O processo criminal foi suspenso pelo prazo de dois anos, com fulcro no art. 89 da Lei 9099/95. O PAD havia sido sobrestado em razão da remessa do IPM à JME.

Situação atual: A Ouvidoria requereu à Corregedoria Geral da BM a instauração de PAD, contra o major $X$, em virtude da independência das instâncias administrativa e criminal. Aguarda resposta.

Os Relatórios Azuis, publicados pela Comissão de Cidadania e Direitos Humanos da Assembléia Legislativa do Estado do Rio Grande do Sul, também incluem relatos semelhantes. Veja-se, por exemplo, este episódio, que consta do relatório relativo ao ano de 1996:

\section{Suicídio fracassado acaba em prisão e espancamento}

No dia 13/05/96, a Comissão de Cidadania e Direitos Humanos da Assembléia Legislativa do Estado do Rio Grande do Sul recebeu a visita do senhor C.T., de 29 anos, pintor, que relatou o seguinte: que por volta das $23 \mathrm{~h}$ do dia 10/05/96, o depoente tentou suicídio em via pública, em cidade vizinha à capital, tendo sido impedido por transeuntes que o deixaram aos cuidados da Brigada Militar. Esta, por sua vez, apresentou o depoente à Delegacia de Polícia (DP) da referida cidade. Na DP foi lavrado Registro de Ocorrência da tentativa de suicídio, e C.T. foi agredido a socos e pontapés em várias partes do corpo. Alega o depoente que as agressões foram praticadas por três policiais civis, sob as ordens do inspetor "M", enquanto estava algemado. A libertação deu-se por volta das 3 horas da manhã, portanto 5 h depois da "detenção" por tentativa de suicídio.

Ao se apresentar na CCDH para denunciar o episódio, C.T. ainda evidenciava no corpo as marcas das agressões sofridas, motivo pelo qual foi solicitado o registro ao serviço de fotografia da Assembléia Legislativa. As referidas fotos foram encaminhadas juntamente com ofício 312/96, datado de 02/06/96, à Corregedoria da Polícia Civil. O documento expedido, além de formalizar a denúncia referida, indicava testemunhas e solicitava providências. Nenhum outro esclarecimento nos foi remetido, além da correspondência expedida pela Corregedoria, datada de 18/06/96, informando que o expediente havia sido enviado para outra divisão da Polícia Civil, em face da circunscrição.

Estes relatos são significativos, pois ajudam a entender as situações reais que se escondem por trás dos números. Alguns relatórios incluem também matérias de jornal com a repercussão das atividades da ouvidoria na imprensa. Este recurso é utilizado por 
alguns ouvidores, quando da instalação da ouvidoria, com o objetivo de demonstrar apoio recebido por parte da sociedade civil. Conseguir publicar estes relatórios, contudo, não é nada fácil, e várias ouvidorias são obrigadas a se contentar com relatórios publicados por via eletrônica, na internet. Com efeito, além dos recursos disponíveis para a sua publicação em formato de livro ou brochura serem limitados, quando não escassos, estes relatórios mostram uma série de fatos e situações irregulares, quando não criminosas, que muitos gostariam de esconder. Naturalmente, o governo estadual pode não apreciar uma ouvidoria crítica demais, pois os seus relatórios podem ser bastante negativos com relação à atuação das polícias que, em última instância, estão sob sua responsabilidade. A relação que se estabelece entre o governo estadual e o seu secretário da segurança pública e a ouvidoria de polícia pode ser um bom indício para avaliar a independência, autonomia e seriedade da ouvidoria. 


\subsection{Relação entre o governo estadual e a ouvidoria de polícia}

Apesar das legislações que instituíram as ouvidorias de polícia ressaltarem que se trata de órgãos autônomos e independentes, na prática a situação é mais complexa. O ouvidor pode até ser independente nas suas atitudes e nas suas idéias, mas, por não ter orçamento próprio, vai sempre depender da colaboração do governo estadual para poder viabilizar os seus projetos. Para efeito administrativo, as ouvidorias precisam ser vinculadas a um órgão do estado. No Brasil, elas estão atreladas ao executivo, e a maioria delas está vinculada à secretaria de segurança pública, a quem também estão subordinadas as polícias. Esta realidade não condiz com a tradição do instituto do ombudsman, que originalmente foi criado como parte do poder legislativo para poder fiscalizar as ações do executivo. Diante de uma situação de confronto entre o ouvidor e o secretário de segurança, este pode dificultar ou impedir a transferência dos recursos destinados à ouvidoria. Não se trata necessariamente de recursos materiais, como mostra o depoimento de Fermino Fecchio:

“Administrativamente, a ouvidoria é ligada ao secretário da segurança. Então, se ele quiser, ele pode pisar no seu tubo de oxigênio. É o que fizeram comigo. Ele não te dá computador, não te nomeia funcionários. Em todo quadro de funcionários, tem uns que casam, outros que passam em concurso, e os salários são pequenos. Como é que você traz gente de fora? Não é nada fácil. E mesmo você achando um, você diz: "Olha, nomeia esse cara aqui." E o secretário não nomeia. O ouvidor tem o direito de escolher os seus assessores. Você escolhe de acordo com seus critérios próprios, mas tem que encaminhar um ofício ao secretário, que por sua vez o encaminha para a casa civil, e sai no diário oficial. Você depende dele. Então, se ele não encaminha e se ele não quer 
nomear, você fica esperando, esperando. E você trabalha sem ninguém. Então, eu ficava mendigando material de escritório. Quebrava o computador, poxa vida, não tem computador! (...) Um pouco são essas as dificuldades materiais. Dificuldades de garantia orçamentária, de independência financeira, você poder suprir as necessidades das ouvidorias."

A seguinte declaração do ouvidor do Paraná, Luiz Alberto Franco Bordenowski, tem um tom bem diferente e mostra um discurso claramente político, no qual o ouvidor procura defender o governo do qual faz parte:

“A ouvidoria começou a funcionar realmente há dois anos, com Roberto Requião. Somente nos primeiros cinco meses de 2005 já contabilizamos mil atendimentos. Houve uma queda expressiva em 2004, que se deve às medidas repressivas de combate à corrupção empreendidas pelo nosso governador Requião, pois a redução das reclamações acompanhou a queda da violência. $\mathrm{O}$ problema da grande criminalidade no estado se deve à situação econômica péssima com este governo federal que está aí. O governo federal dá lucro unicamente aos bancos. O Brasil é o país com a mais alta taxa de juros dos bancos, e é também o segundo país mais miserável do mundo, só perde para Serra Leoa. O governo estadual não vai eliminar esse tipo de situação, por que ela depende da situação social. O Paraná é o estado mais tranqüilo do país em nível de segurança."76

Naturalmente, esta não é exatamente a reação que se espera de um ouvidor da polícia autônomo e independente em relação ao governo, mesmo que o alinhamento do ouvidor com as posições do governador possa facilitar o seu trabalho:

\footnotetext{
${ }^{76}$ Depoimento dado ao autor a 3 de junho de 2005 .
} 
“Aqui no Paraná, a colaboração do governo é total. Não tem um único percalço. A ouvidoria navega em águas limpas. Houve um episódio, nos primeiros meses após minha chegada na ouvidoria, em que um delegado se recusou a fornecer informações. Pois bem, comuniquei o fato ao governador às 14:00 horas, e às 17:00 horas ele foi exonerado sumariamente, foi afastado do cargo comissionado. Aqui é assim, se alguém sonegar alguma informação, é imediatamente instaurado um inquérito policial militar e iniciado um processo disciplinar."

Bem diferente, foi a experiência de Fermino Fecchio à frente da ouvidoria da polícia de São Paulo de 2000 a 2002. O seguinte relato ilustra como eram as relações entre o governador e o ouvidor na ótica de Fermino Fecchio que, provavelmente, é o que enfrentou a situação mais adversa até agora entre os ouvidores de polícia:

“O primeiro ano que passei na ouvidoria foi muito difícil. Eles demoraram quatro meses para me nomear, apesar de ter sido indicado pelo conselho. O Mariano saiu dia 30 de dezembro de 2000. A Marta começou a governar em 2001. Ele já começou no governo Marta, então ele tinha que sair. Faltavam meses para ele terminar o mandato, mas ele pediu e saiu, e o conselho já encaminhou a minha indicação numa lista tríplice, mas o secretário sabia que eu era o indicado. Naquele tempo ainda era o Mário Covas e tinha um bom diálogo com o secretário, e foi encaminhado logo. Mas eu só fui nomeado no final de abril. Quanto eu fui nomeado, já tinha morrido o Mário Covas. Eu tenho um azar danado, por que quando eu chego não tem o Mário Covas, não tem Dom Paulo. Essa intermediação com o Covas era feita pelo Dom Paulo. Dom Paulo fazia questão da ouvidoria. Quando eu chego, ele se aposenta e o Mário 
Covas morre. Então eles me deixam e o secretário tinha me dito isso: "Olha, eu não vou cometer outra vez o mesmo erro. Nomearam um cara ouvidor do PT, agora vou nomear outro cara do PT, não vou nomear." Foi assim que eu fui recebido na secretaria. E eles demoraram, um mês, dois meses, três meses, quatro meses. Mas aí o conselho começou a cobrar o Alckmin que estava começando. Eu fiquei lá trabalhando sem ser nomeado sem nada, por que eu já era assessor da ouvidoria. Quando saiu o ouvidor, eu fiquei no lugar dele, tocando a ouvidoria. Então a ouvidoria continuou sem ouvidor, todo esse tempo. Aí a OAB começou a ligar, a Comissão Justiça e Paz começou a fazer pressão e o governador foi obrigado a nomear. Acontece que o Mariano tinha levado setenta por cento da equipe da ouvidoria junto com ele para a prefeitura. Eu não tinha mais ninguém. Todos os quadros vazios. Aí então eu falei: não adianta nomear só o ouvidor, eu preciso de advogados. Aí me nomearam três assessores. Não preencheu todo o quadro, mas deu para equilibrar o jogo. No começo de maio, estava com o quadro começando a funcionar. Aí, em junho, o secretário me chama e diz: "Amarra todas as tuas coisas, empacota tudo aí que vocês vão mudar daí. Vai ser fechado o prédio, vamos transferir todo mundo para outro prédio.” Bom, isso em junho, julho. Você imagina, guardar tudo. Tem muito expediente na ouvidoria, muita coisa. Você começa a botar em caixas. Bom, eu vou mudar no final de outubro, com tudo empacotado. Fico meses funcionando precariamente, empacotando coisas, atendendo gente, aquela história. Vamos mudar quase no final do ano, véspera de Natal, sem nada instalado, sem mesa, sem cadeira. Me transferiram para um prédio lá na Libero Badaró que dava medo. Você tinha que ver quando eu cheguei lá. Estava tudo desmontado. Não tinha energia elétrica, não tinha água, não tinha nada. Eu não podia ligar o 
computador e nada, duas coisas que você ligava e pifava o sistema elétrico, com ameaça de incêndio, aquela coisa toda. Poeira para todos os cantos. Tive que pedir ajuda a empresários, comerciantes, vizinhos, e foram eles que instalaram divisórias num prédio do Estado, num prédio público. A hora que dava para sentar numa cadeira, atender ao telefone, ter o computador ligado, foi em janeiro, fevereiro do ano seguinte, em 2002. Então, praticamente, eu funcionei de meados de 2002 a meados de 2003, quando o governador, sabiamente, não me reconduziu."

Ainda de acordo com Fermino Fecchio, como o governador não podia demitir o ouvidor, ou substituí-lo por outro mais camarada, ele tentou afastá-lo do público. A Imprensa Oficial, que desde a instalação da ouvidoria bancava cinco estagiários e publicava os relatórios anuais, deixou de colaborar. Os estagiários foram retirados e o último relatório publicado foi o de 2001. A estratégia utilizada pelo ouvidor para divulgar o trabalho da ouvidoria foi a criação de um site na internet, no qual passou a colocar os relatórios trimestrais e anuais, e a publicação de um jornal eletrônico com notícias e análises sobre as denúncias recebidas que era distribuído a mais de mil endereços eletrônicos. De agosto de 2001, quando foi inaugurado, a abril de 2003, quando o ouvidor foi substituído, foram publicados 39 números. (No ANEXO 6 incluímos três exemplares do Otite Crônica)

A divulgação de dados relativos ao número de policiais mortos e que mostram que os policiais morrem mais durante o bico, nas horas de folga, do que quando a serviço da polícia, assim como a publicação do fato de que a quantidade de agentes policiais que cometem suicídio é superior ao número de policiais que morrem em serviço, não foram bem recebidas pelo governo do estado. Posteriormente, a denúncia da existência de grupos de extermínio em Ribeirão Preto e em Campinas, e o 
desmascaramento da forma de atuação do Grupo de Repressão e Análise dos Delitos de Intolerância (GRADI), formado por policiais militares, lotados no próprio gabinete do secretário da segurança pública, que utilizavam presos como informantes e os infiltravam em organizações criminosas antes de eliminá-los, causou muita repercussão. A partir daí, as relações entre o ouvidor e o governo do estado azedaram de vez:

"O Otite Crônica foi o jeito que encontrei de romper o cerco que eles me impuseram. Aí eles passaram a me sonegar informações, não divulgavam as estatísticas, não me atendiam. Ligavam para a PM e diziam: “olha, não informa mais nada para ele, não devolve expediente para ele". Eu oficiava, mandava para o corregedor, o corregedor pegava tudo e me mandava de volta. Isso era importante. Em um mês, eu recebia todas as coisas de volta. Aí passa a demorar dois meses, três meses, passam a me sonegar informações. Então, eu comecei a ir buscar informação. Eu ia buscar dados, ia nas varas criminais, pegava o inquérito que eu queria ver. Ele não me dava a informação, eu ia, os meus assessores eram advogados, ia na vara criminal, pegava o inquérito, tirava xerox do laudo, tirava xerox do relatório do delegado, tirava o que precisasse, e com isso criava meu expediente, fazia circular, e fazia minhas estatísticas. Via os policiais que estavam envolvidos, foi assim. Olha, é duro. Isso é ruim porque a ouvidoria tem que trabalhar em harmonia com o governador, com o secretário, esse é o ideal. Eu nunca pude fazer isso, desde o começo foi difícil. O governador ia à televisão desautorizar o ouvidor, o Alckmin fez isso várias vezes, você percebe? Se o governador vem falar mal do ouvidor, por que o delegado corregedor tem que me atender? Por que o delegado lá do interior que ouve um pedido meu de informação urgente tem que me atender? A coisa começa a ficar difícil.” 
A divulgação das informações e do resultado dos trabalhos da ouvidoria é sempre delicada. Trata-se, talvez, do momento com maior potencial de atrito entre o governo e a ouvidoria. Vários ouvidores se manifestaram no mesmo sentido. A ouvidora da polícia do Pará, Rosa Marga Rothe, que esteve à frente da ouvidoria desde a sua criação, em 1997, analisava a questão da seguinte maneira, dois meses antes de ser substituída por um delegado de polícia aposentado, que já foi Corregedor Geral da Polícia Civil e Secretário da Segurança do Pará:

"Nós não temos mais sentido apoio do governo atual. O secretário anterior, Paulo Sette Câmara, nos dava todo o apoio. Trata-se de um policial de carreira antigo, mas que não parou no tempo. O reconhecimento que temos hoje é fruto de seis anos de conquistas, mas nos últimos dois anos não sentimos mais apoio. Quando soltamos o relatório, só falta bater na gente. Ficam preocupados com cifras, e não com os fatos que essas cifras mostram. O relatório referente ao ano de 2003, por exemplo, ainda não foi aprovado, pois não concordam com os dados relativos à tortura e aos homicídios cometidos por policiais. Alegam que apenas um juiz pode dizer se foi tortura ou homicídio, e dizem que nós não podemos usar essas categorias. Respondemos que todos os ouvidores usam esses termos, mas de nada adiantou. Aí, desmembramos o relatório e vou reapresentálo. (...) As reações da polícia civil e da polícia militar são endossadas pelo secretário da defesa. Eu é que fico insistindo nesses relatórios, porque eles não fazem nenhuma questão. Se não fizer, é até melhor. No fundo, eles ficam muito incomodados porque sabem que temos muitos laços com a sociedade civil." 77 Ao entregar o cargo para o seu substituto, em agosto de 2005, Rosa Marga Rothe ainda não havia conseguido divulgar o relatório relativo ao ano de 2004. Questionado a

\footnotetext{
${ }^{77}$ Depoimento dado ao autor a 13 de junho de 2005.
} 
este respeito, o novo ouvidor, Lélio Railson Dias de Alcantara afirmou que não tinha nada a ver com o relatório do ano anterior: "A minha preocupação é apenas com o relatório de 2005, que será produzido no ano que vem." 78

Como se vê, a experiência tem mostrado que o ouvidor precisa ter muito jogo de cintura para lidar com as resistências e escolher o melhor momento para divulgar os relatórios. O depoimento do ouvidor da polícia do Rio Grande do Norte, Marcos Dionísio Medeiros Caldas, ilustra bem este argumento:

"Quando divulgo o relatório, o impacto é muito grande. A turma não gosta. Posso ir à mídia fazer denúncias sem problemas, mas é preciso avaliar bem qual é a melhor época para divulgar o relatório. Há pouco tempo, por exemplo, tivemos 21 policiais militares presos que tiveram que ser transferidos para Belém do Pará. Eles faziam parte de um grupo de extermínio que foi descoberto a partir de uma denúncia na ouvidoria. A gente aproveitou para soltar o relatório naquele momento em que havia apoio da sociedade e as atenções estavam voltadas para isso. Fizemos, também, uma pesquisa sobre o índice de impunidade que causou grande repercussão. Vários homicídios não estão sendo apreciados pela justiça. Agora, com muita habilidade, estou conseguindo quebrar a caixa preta. Foi um escândalo tão grande que fiquei sem ar para respirar, aí, com certa malícia, a gente começou a jogar. Como o clima ficou meio pesado na secretaria de segurança pública, recuei das acusações. Em alguns momentos recuo, em outros me aproximo." 79

\footnotetext{
${ }^{78}$ Depoimento dado ao autor a 22 de agosto de 2005.

${ }^{79}$ Depoimento dado ao autor a 10 de junho de 2005.
} 
Minas Gerais: a importância do diálogo com a sociedade

Os exemplos anteriores mostram que o apoio da sociedade é um esteio importante das ouvidorias sobretudo em momentos de dificuldades. Em Minas Gerais, José Francisco da Silva, ouvidor da polícia do estado desde novembro de 2002 e atual coordenador do Fórum Nacional de Ouvidores da Polícia, tem conseguido avanços significativos neste sentido. A sua receita é simples: muito diálogo com todos os setores da sociedade interessados na atividade policial.

Naturalmente, esses resultados só foram possíveis graças ao apoio do governo do estado e ao desenho institucional da ouvidoria que, até dezembro de 2004, era ligada ao gabinete do governador. A ouvidoria da polícia era uma unidade administrativa equivalente a uma secretaria de governo. A partir da criação da ouvidoria geral do estado, em maio de 2005, ela passou a depender deste órgão e perdeu um pouco da sua autonomia e independência. O ouvidor geral é um desembargador que já foi presidente do Tribunal de Justiça de Minas Gerais e, em vários momentos, os interesses políticos acabam predominando. No projeto original de criação da ouvidoria geral, estava prevista a junção da ouvidoria da polícia com a ouvidoria penitenciária. O ouvidor conseguiu manter a separação entre os dois órgãos, mas não teve sucesso na tentativa de garantir verbas próprias para a ouvidoria. ${ }^{80}$

Ao assumir a ouvidoria, José Francisco da Silva encontrou condições de trabalho precárias, com poucos funcionários sem qualificação técnica além dos assessores das polícias civil e militar e dois técnicos cedidos pela administração pública estadual. Seu principal desafio foi melhorar a imagem da ouvidoria, que era considerada um órgão inquisidor pelas corporações policiais. Em fevereiro de 2003, a ouvidoria organizou um

\footnotetext{
${ }^{80}$ Depoimento dado ao autor a 21 de outubro de 2005.
} 
seminário com os corregedores, os comandos da polícia militar e da polícia civil, e organizações de defesa dos direitos humanos que, nas palavras do ouvidor:

"foi muito bem sucedido, pois abriu um processo de diálogo muito grande. Claro que houve momentos difíceis, com desentendimentos, quando, por exemplo, tivemos que solicitar o afastamento de policiais envolvidos para que fosse possível fazer uma avaliação com lisura. Mas fomos nos aproximando, mostrando nossa função."

A partir daí, a ouvidoria se esforçou em manter e ampliar esse canal de comunicação, de modo a servir de interface entre diversos setores da sociedade civil e as corporações policiais. Ao longo dos últimos três anos, foram realizados vários cursos de formação de agentes policiais articulados com uma reflexão sobre direitos humanos, graças a uma parceria entre o governo federal e o governo estadual e a um convênio entre a SENASP, do Ministério da Justiça, e o Centro de Assessoramento a Programas de Educação para a Cidadania (CAPEC), de acordo com o programa elaborado por Ricardo Brisolla Balestreri. ${ }^{81}$ [Balestreri, 2003] Os cursos permitem a convivência dos policiais com os conselhos comunitários, as prefeituras, as pastorais, e ONGs ligadas aos direitos humanos e levam a resultados surpreendentes, como mostram os seguintes episódios narrados pelo ouvidor:

"Na semana passada, estive num desses cursos e recebi a seguinte manifestação, de um cabo da polícia militar: “Ouvidor, eu só queria dizer uma coisa para o senhor, é a primeira vez que posso conviver intensamente com aqueles com quem trabalho o tempo todo: a sociedade. Ouvidor, por favor, não feche o canal, precisamos dessa comunicação.” Em outra ocasião, ao final da palestra um policial se levantou e disse: "Quero agradecer a oportunidade que

\footnotetext{
${ }^{81}$ O CAPEC também realizou cursos semelhantes no Rio Grande do Norte, assim como cinco jornadas de Direitos Humanos e seminários combatendo o racismo, a tortura, e abordando a melhor maneira de lidar com deficientes mentais e adolescentes, para um público total de 3500 policiais.
} 
tive de conhecer a ouvidoria. Confesso que tinha fantasmas a esse respeito." Essas manifestações, para mim são muito importantes, pois são os cabos, sargentos e praças que fazem a polícia. Ontem mesmo, havia no jornal uma fala muito positiva do vice-presidente da associação dos praças, que até agora era o nosso algoz."

Com efeito, na edição do dia 21 de outubro de 2005 do jornal $O$ Tempo, uma matéria sobre o aumento do número de denúncias na ouvidoria destacava a seguinte declaração do vice-presidente da Associação dos Praças Policiais e Bombeiros Militares de Minas Gerais (Aspra-MG), subtenente Luiz Gonzaga Ribeiro: “a estatística revela que o controle externo das atividades policiais tem sido eficiente. Felizmente, a população está menos receosa em denunciar. Esse aumento é muito positivo, sobretudo porque desestimula a ocorrência de irregularidades na nossa atividade policial".

Para permitir a participação de pessoas de todo o estado, os cursos são realizados em Belo Horizonte, Contagem, Santa Luzia, Nova Lima, Montes Claros, Juiz de Fora, Ipatinga, São João Del Rei, Poços de Caldas e Uberlândia.

Este contato entre policiais e cidadãos fora das situações em que costumam se encontrar, que é na lavratura de uma ocorrência, é importante porque explicita para os policiais uma dupla reivindicação da sociedade: que a polícia proteja as pessoas, mas apenas dentro da lei e do respeito. Enquanto, no calor da hora, as vítimas de delitos muitas vezes querem que a polícia prenda os criminosos e seja dura com eles, uma vez passado o susto essas mesmas pessoas podem ter sentimentos diferentes e desejar que a polícia trate a todos como cidadãos. [Stone, 2003] Muitos policiais simplesmente não acreditam que os cidadãos que pedem a sua proteção realmente se importam com a maneira como a polícia desempenha suas funções pela única razão que a sua experiência cotidiana é de que as pessoas com quem convivem diariamente, seus 
superiores e vítimas de delitos, ficam inteiramente satisfeitos se desrespeitarem algumas regras para garantir a segurança pública. Os policiais interagem muito pouco com os cidadãos que dão igual importância ao profissionalismo no policiamento. Nas palavras de Christopher Stone, eles "não vivenciam os dois lados da dupla exigência".

Seguindo a mesma lógica da interiorização das ações da ouvidoria, foi desenvolvido o projeto Ouvidoria Itinerante, que procura estender ao cidadão que reside no interior o serviço de recepção de denúncias. Através de ações de mobilização, a ouvidoria identifica parcerias locais como ONGs, entidades de direitos humanos, representantes do legislativo, associações de classes e moradores, universidades e representantes das polícias e organiza um encontro técnico, durante o qual é apresentado o papel de controle externo, seus objetivos, sua articulação com os demais órgãos da defesa social e o fluxograma das denúncias. O próximo passo é a instalação da Ouvidoria Itinerante, composta pelo próprio corpo técnico da ouvidoria e atendentes treinados localmente, que se instalam temporariamente nas dependências de um órgão de fácil acesso à população. Atendendo a uma sugestão do Conselho Estadual de Direitos Humanos e após a análise do conjunto de denúncias recebidas na ouvidoria, o projeto Ouvidoria Itinerante já foi realizado nos seguintes municípios: Montes Claros, Ipatinga, Diamantina, Uberlândia, Contagem, Sete Lagoas, Ouro Preto, Santa Luzia, Araçuai, Várzea da Palma e Sabará.

Atualmente, está em implantação um conjunto de nove núcleos da ouvidoria no interior do estado. Cada núcleo é composto por uma equipe formada por meio de parcerias com instituições de ensino superior e as prefeituras locais e representa a ouvidoria nas localidades mais críticas (ouve a população, recebe queixas e denúncias, verifica a pertinência das mesmas, comunica os fatos ao ouvidor, divulga as atividades da ouvidoria junto à sociedade civil local, monitora a violência policial na região). $\mathrm{O}$ 
projeto foi iniciado em novembro de 2004 e, até o final do ano de 2005, deverá contar com nove núcleos da ouvidoria, nas cidades de Poços de Caldas, Diamantina, Montes Claros, Contagem, São João Del Rei, Uberlândia, Ipatinga, Juiz de Fora e Teófilo Otoni.

De uma maneira geral, em todas as ouvidorias de polícia já instaladas no país o número de denúncias relativas a fatos ocorridos no interior do estado é muito inferior ao número de denúncias da capital, onde está localizada fisicamente a ouvidoria. ${ }^{82}$ Em Minas Gerais, esta relação se inverteu a partir da instalação da ouvidoria no interior do estado. Com a instalação dos seis primeiros núcleos da ouvidoria, as denúncias recebidas pela ouvidoria da polícia de Minas Gerais aumentaram em 50\% no primeiro semestre de 2005. Este resultado já era esperado se levarmos em conta que tanto a população, quanto os efetivos das polícias, são mais numerosos no interior do que na capital. Para o ouvidor, deve ser levada em conta também a grande repercussão que a instalação dos núcleos teve na mídia, o que possibilitou tornar mais conhecido o trabalho da ouvidoria mesmo em regiões onde ela não se instalou fisicamente. Ele chama a atenção, também, para a inauguração do disque-corrupção da ouvidoria da polícia (0800-289 9191) em março de 2005, e constata que o aumento do número de denúncias é muito mais significativo para a polícia militar do que para a polícia civil.

\footnotetext{
${ }^{82}$ Os números são os seguintes para a porcentagem de denúncias de fatos ocorridos nas capitais e respectivas regiões metropolitanas: Belo Horizonte (MG) 77,13\% em 2003; Belém (PA) 61,86\% de 1998 a 2000, 71,35\% em 2002, 69,4\% em 2003; Natal (RN) 79,6\% de 2001 a 2004; Porto Alegre (RS) $43,63 \%$ de 1999 a 2001; Curitiba (PR) 64\% em 2004; São Paulo (SP) 68,75\% em 2001 e 66,72\% em 2002.
} 


\section{Classificação das denúncias de acordo com a região onde ocorreram os fatos (Minas Gerais)}

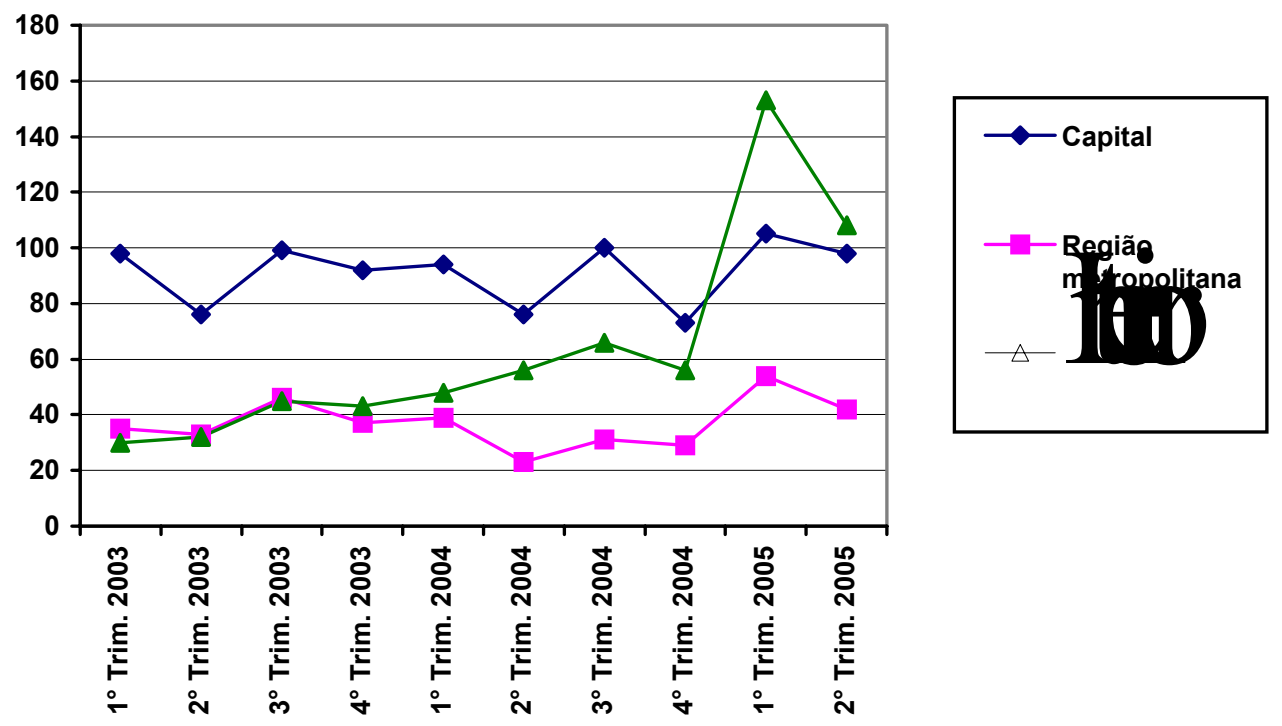

Esses resultados comprovam que um obstáculo a um trabalho mais efetivo das ouvidorias de polícia é o seu desconhecimento por parte do público em geral. Com efeito, há pesquisas que comprovam que a maioria da população não tem conhecimento da existência da ouvidoria de polícia, e quando o tem, atribui a ela funções e poderes que não estão ao seu alcance.

Uma pesquisa realizada em 2004 por meio de 800 questionários, na região metropolitana de Belo Horizonte, revelou que 78,8\% dos entrevistados desconheciam o órgão de fiscalização das polícias civil e militar de Minas Gerais (8,9\% afirmaram que conheciam e 10,3\% já ouviram falar). Quando foi solicitado àqueles que conheciam ou tinham ouvido falar que apontassem o nome do órgão de fiscalização das polícias, apenas $28,7 \%$ responderam corretamente que era a Ouvidoria de Polícia. ${ }^{83}$

Uma outra pesquisa realizada junto aos denunciantes que procuraram a ouvidoria de janeiro de 2001 a setembro de 2003, mostra que apenas 16\% dos entrevistados conheceram a ouvidoria pelos meios de comunicação. De acordo com os

\footnotetext{
${ }^{83}$ OUVIDORIA DA POLÍCIA DE MINAS GERAIS. A Ouvidoria de Polícia de Minas Gerais mostra o que faz. Belo Horizonte, Artes Gráficas Formato, 2004.
} 
resultados obtidos, as pessoas parecem chegar à ouvidoria muito mais através da indicação de conhecidos ou de outras instituições do que como conseqüência da divulgação das atividades da ouvidoria na mídia. [Cano, 2004]

Completam esses dados, ainda segundo a mesma pesquisa, a informação de que um número significativo dos entrevistados (19\%) atribuem à ouvidoria competências que esta não possui, como investigar, punir ou corrigir policiais, e o fato de que $44 \%$ deles terem procurado também outras instâncias de denúncia, como organizações de direitos humanos, a própria polícia, o ministério público, o poder judiciário, a imprensa ou outros órgãos do governo.

Uma pesquisa semelhante, coordenada por Julita Lemgruber junto a denunciantes no Rio de Janeiro e em São Paulo, encontrou resultados muito parecidos com os de Minas Gerais. [Lemgruber et alii, 2003] Muitos entrevistados afirmaram que era preciso divulgar melhor o trabalho da ouvidoria.

A disponibilidade do telefone das ouvidorias - a importância da divulgação

A divulgação do telefone da ouvidoria é fundamental, pois a maioria das denúncias é feita por comunicação telefônica. Com o intuito de avaliar a disponibilidade do telefone da ouvidoria da polícia de São Paulo, realizamos o seguinte teste: telefonamos para 183 delegacias de polícia da grande São Paulo e perguntamos, como o faria um cidadão comum, pelo telefone da ouvidoria. Vale a pena ressaltar que o número 0800-177070 existe há dez anos, desde a criação da ouvidoria. Os resultados mostram que em apenas 16 delegacias foi fornecido o número correto, o que corresponde a $8,7 \%$ do total. Se levarmos em conta apenas os distritos policiais da capital, conseguimos apenas 5 respostas certas em 93 distritos, o que corresponde a somente $5,4 \%$ dos casos. Na maioria das vezes, tivemos a impressão que a nossa 
pergunta ("Por favor, você poderia me informar o telefone da ouvidoria?") causou perplexidade para a pessoa que atendeu ao telefonema. Em duas delegacias, até, fomos informados pelo nosso interlocutor que éramos a primeira pessoa que fazia essa pergunta. Em várias ocasiões, o atendente nos perguntou se estávamos interessados na ouvidoria da polícia civil ou na ouvidoria da polícia militar, o que pode ser um indício de um alto grau de desconhecimento da ouvidoria da polícia para a corporação policial. Em outros casos, ao contrário, o policial que atendeu mostrou-se preocupado, ofereceuse para receber a denúncia e tentou nos dissuadir de procurar a ouvidoria. (O detalhamento completo dos resultados encontra-se no ANEXO 4).

Um levantamento semelhante, junto a 222 batalhões da polícia militar da grande São Paulo, resultou em 37 respostas satisfatórias, o que representa um índice de acerto de $16,7 \%$, o dobro do índice referente aos distritos policiais. A busca pelo número de telefone da ouvidoria junto a batalhões da grande São Paulo foi um pouco mais bem sucedida do que nas unidades localizadas no município de São Paulo. Se isolarmos, contudo, as respostas relativas aos batalhões da região do grande $\mathrm{ABC}$ (Santo André, São Bernardo do Campo, São Caetano do Sul, Diadema, Mauá, Ribeirão Pires e Rio Grande da Serra), onde obtivemos um índice de acerto de $28 \%$, os resultados para o restante da região da grande São Paulo são semelhantes aos da capital. Podemos entender este fato com a importância do episódio da Favela Naval, ocorrido em Diadema, para a aprovação da lei que instituiu a ouvidoria da polícia de São Paulo. (Para ver o resultado detalhado da pesquisa, remetemos o leitor ao ANEXO 5).

Seja como for, o telefone da ouvidoria da polícia não é um número que os agentes policiais consultados acham com facilidade. Mesmo quando obtivemos respostas satisfatórias, o tempo médio que tivemos que aguardar foi de mais de um minuto, tanto para a polícia civil quanto para a polícia militar (1 minuto e 17 segundos e 
1 minuto e 21 segundos, respectivamente). Em apenas uma ocasião o telefone estava à mão do atendente, que demorou apenas 5 segundos para localizá-lo, e chegamos a esperar quase cinco minutos na linha para conseguir o número solicitado. Pareceu-nos grave o fato de, em várias ocasiões, o número fornecido ser o da corregedoria e não o da ouvidoria.

Há de se considerar, também, que a simples intenção manifestada de entrar em contato com a ouvidoria pode ser intimidadora para um policial não familiarizado com o a prática do controle externo. Veja-se, por exemplo, o seguinte testemunho de Rosa Marga Rothe:

"De acordo com vários relatos, o folheto da ouvidoria pregado na porta de casa pode funcionar como um escudo protetor. Outros contam que apenas pronunciaram a palavra ouvidoria e os policiais recuaram. Tais experiências ajudam na multiplicação de atentos observadores e de testemunhas destemidas, capazes de muitas e importantes contribuições." [Rothe, 2000]

A ouvidoria da polícia do Rio Grande do Norte também elaborou uma cartilha para divulgar as ações e possibilidades oferecidas pela ouvidoria. Trata-se de textos curtos sobre as atividades da ouvidoria, divididos nos seguintes itens:

Apresentação

O que é a ouvidoria?

Quem é o ouvidor?

Funcionamento da ouvidoria

Como denunciar? Como nos localizar? ${ }^{84}$

\footnotetext{
${ }^{84}$ A cartilha está disponível na internet, no endereço:

http://www.segurancacidada.org.br/controle/ouvidorias/ouvidoria rn/cartilha ouv rn.htm
} 
Quase todos os ouvidores consultados reclamaram da falta de verba para fazer uma divulgação mais eficiente da ouvidoria. Alguns apontaram, inclusive, a omissão do governo do estado que poderia fazer essa divulgação com facilidade. Como tentativa de obrigar o governo a fazê-lo, surgiram projetos de lei em algumas assembléias legislativas.

Projetos de lei para divulgar o telefone da ouvidoria nas viaturas da polícia

A exemplo do telefone do disque-denúncia, que é veiculado em uma grande parte dos ônibus da cidade de São Paulo, há projetos de iniciativas semelhantes em alguns estados. Na Assembléia Legislativa do Estado de Minas Gerais, por exemplo, encontra-se atualmente em tramitação o projeto de lei 1789/2004, de autoria do deputado Padre João (PT), que tem por objetivo a divulgação do telefone da ouvidoria da polícia através da frota da polícia militar, da polícia civil e do corpo de bombeiros militar do estado. ${ }^{85}$ No texto da proposição que justifica o projeto de lei, o deputado cita a pesquisa já mencionada que mostra o alto grau de desconhecimento da ouvidoria da polícia de Minas Gerais e o relaciona à falta de providências da parte das vítimas da violência policial. O texto se inspira num projeto similar, em tramitação na Assembléia Legislativa do Estado do Rio de Janeiro e que foi elaborado pelo deputado Carlos Minc (PT), que é também o autor da lei que instituiu a ouvidoria da polícia no estado. ${ }^{86} \mathrm{Na}$ Assembléia Legislativa do Estado de São Paulo, o projeto de lei que visa divulgar o

\footnotetext{
${ }^{85} \mathrm{O}$ artigo segundo do referido projeto, por exemplo, propõe que: “Art. $2^{\circ}$ - A divulgação (...) se dará através de adesivos de tamanho e forma que permitam fácil leitura, à distância e em movimento, com os seguintes dizeres: RECLAMAÇÕES, ELOGIOS E SUGESTÕES DISQUE OUVIDORIA DA POLÍCIA : (31) 3274-0625"

${ }^{86}$ Trata-se do projeto de lei $2116 / 2001$, cujo artigo $2^{\circ}$ tem a seguinte redação: “A divulgação (...) se dará através de adesivos de tamanho e forma que permitam a fácil leitura, à distância e em movimento, com os seguintes dizeres: 
telefone da ouvidoria é o PL n ${ }^{0}$ 591/2003, de autoria do deputado Renato Simões (PT), que se assemelha em tudo aos dois já mencionados. ${ }^{87}$ As discussões que estes projetos desencadeiam quando são discutidos no plenário das respectivas casas em que foram propostos dão uma boa idéia das resistências que as ouvidorias de polícia ainda enfrentam em certos setores da sociedade. Veja-se, por exemplo, a manifestação do deputado Paulo Ramos (PDT), por ocasião da votação em primeira discussão do projeto de lei 2116/2001, na Assembléia Legislativa do Estado do Rio de Janeiro, a 6 de novembro de 2003:

"Sou contra (...) porque, às vezes, com uma sedução dessas irão transformar as viaturas policiais numa espécie de circo. Por outro lado, essa questão de ouvidoria tem gerado muitos problemas e, pessoalmente, sou contra."

Na mesma sessão, o seu colega, deputado Domingos Brazão (PMDB), se pronunciou com argumentos semelhantes:

“Sr. Presidente, encaminho o voto 'não', por vários motivos. O primeiro é para não criar mais confusão para as pessoas. O telefone 190, que consta nos carros da Polícia, é o número mais usado no Estado, com quase $600 \mathrm{mil}$ ligações/mês. Como vamos agora arrumar um espaço para colocar o telefone da Ouvidoria da Polícia? Não faz sentido! Vai causar uma despesa tremenda, precisará pintar a viatura toda. Estamos precisando é de viatura na rua! Para o carro para pintar telefone, Sr. Presidente, é brincadeira! Ninguém cria nada para ajudar a Polícia! Mas para criar complicação!”

Vale ressaltar que até o momento (julho de 2005) nenhum destes projetos foi concretizado. O ouvidor da polícia de Minas Gerais afirmou que não vai fazer deste projeto o seu cavalo de batalha, pois as resistências são muito grandes, mas enviou um

\footnotetext{
${ }^{87} \mathrm{O}$ artido $2^{\circ}$ do projeto de lei $\mathrm{n}^{\circ}$ 591/2003 tem a seguinte redação: “A divulgação (...) se dará através de adesivos de tamanho e forma que permitam a fácil leitura, à distância e em movimento, com os seguintes dizeres: 
ofício ao governador para solicitar a inclusão do número de telefone da ouvidoria no contracheque dos servidores estaduais. ${ }^{88}$

Curiosamente, o argumento do excesso de informações nos carros da polícia, avançado pelos adversários da divulgação do telefone da ouvidoria, não impede as viaturas da polícia militar de São Paulo de circular com um adesivo no vidro traseiro com a seguinte mensagem:

\section{INCENTIVE A DOAÇÃO DE ÓRGÃOS \\ SECRETARIA DA SAÚDE - GOVERNO DO ESTADO DE SÃO PAULO}

Não podemos deixar de lembrar que a polícia militar de São Paulo faz a sua parte para aumentar o contingente de doadores potenciais. Com efeito, uma pesquisa sobre o uso da força letal por policiais de São Paulo no ano de 1999, realizada pela ouvidoria da polícia revelou que $81,25 \%$ das vítimas eram jovens de até 35 anos de idade e que $86,82 \%$ dos policiais envolvidos pertencem à Polícia Militar. Um levantamento realizado pelo jornal Diário de S.Paulo na Ouvidoria da Polícia do Estado de São Paulo, em 2004, conseguiu examinar 607 casos entre as 868 mortes registradas em confrontos com a Polícia Militar. O resultados são semelhantes: 97,22\% das 431 vítimas com idade conhecida tinham até 35 anos. ${ }^{89}$

\footnotetext{
${ }^{88}$ Depoimento dado ao autor a 21 de outubro de 2005.

${ }^{89}$ Os dados constam do Relatório Anual de Prestação de Contas - 2000 da Ouvidoria da Polícia do Estado de São Paulo e do caderno especial "Mortos pela PM" publicado na edição de 3 de abril de 2004 do Diário de S.Paulo.
} 
Limites das ouvidorias de polícia e a questão das investigações

Para que a experiência das ouvidorias de polícia possa continuar e frutificar, é preciso que os argumentos normativos a favor do controle externo que estiveram na origem da sua criação (transparência, fiscalização, prestação de contas, adequação aos princípios dos direitos humanos) sejam corroborados por evidências mais concretas dos seus benefícios (diminuição da violência e dos abusos por parte da polícia, menos crimes dos policiais, maior satisfação dos cidadãos quanto ao desempenho da polícia). [Brereton, 2000]

A partir da maneira como foram criadas e institucionalizadas as ouvidorias de polícia no Brasil, contudo, seria um erro pretender julgá-las e avaliá-las pelo que elas não podem fazer:

- $\quad$ investigar os crimes cometidos por policiais,

- $\quad$ punir os policiais infratores.

Devemos, contudo, avaliar as ouvidorias pelo que está em seu poder e ao seu alcance:

reunir as informações e dados sobre a atuação da polícia e ouvir os cidadãos,

- provocar as organizações policiais e os órgãos competentes para que tomem providências para a solução das queixas apresentadas, e cobrar dos mesmos respostas satisfatórias para a população, organizar os dados e sugerir mudanças no padrão de comportamento da polícia, por meio de projetos de lei ou de resoluções internas das polícias, 
- divulgar os dados para o público por meio de relatórios, entrevistas coletivas, artigos na imprensa,

- $\quad$ incentivar e facilitar a participação popular.

Há, ainda, um objetivo implícito na própria razão de ser das ouvidorias de polícia que é diminuir os abusos e crimes da polícia. Este, contudo, é muito difícil de ser avaliado, pois não há parâmetros de comparação, mesmo que indiretamente bons resultados possam ocorrer.

Muitas das frustrações com relação ao funcionamento das ouvidorias de polícia, e aos seus resultados pouco visíveis para a população em geral, se devem às suas limitações institucionais. Vários denunciantes reclamam da falta de resposta adequada por parte das ouvidorias, quando, na verdade, as providências esperadas dependem das corregedorias e do ministério público. Muitos se perguntam, portanto, se não seria o caso de atribuir às ouvidorias de polícia alguma forma de poder investigativo. Esta é a opinião de Julita Lemgruber, que defende que as ouvidorias adquiram alguma capacidade de desenvolver investigações próprias, paralelas ou alternativas às realizadas pelas corregedorias de polícia, para contrabalançar o fechado corporativismo que ainda prevalece nos organismos de controle interno da atividade policial. [Lemgruber et alii, 2003] A autora lembra com freqüência que em alguns países, como na Irlanda do Norte, a ouvidoria de polícia (Police Ombudsman for Northern Ireland) comanda as investigações contra policiais. A ouvidora da polícia da Irlanda do Norte, Nuala O’Loan, que é a titular da ouvidoria desde a sua instalação, em 1998, investiga toda e qualquer queixa contra policiais. Ela tem, inclusive, poder de polícia, ou seja, pode determinar a prisão de qualquer policial acusado de práticas irregulares, e tem autoridade para determinar a punição a ser imposta. O mesmo acontece na ouvidoria da 
polícia da África do Sul (Independent Complaints Directorate). ${ }^{90}$ Outros países em que as ouvidorias da polícia têm poder investigativo são a Inglaterra (Independent Police Complaints Commission), a Bélgica (Comité Permanent de Contrôle des Services de Police) e a Austrália, mas apenas uma minoria dos casos de irregularidades policiais é investigada pelas dez agências de controle externo australianas. [Lewis e Prenzler, 1999]

Em Portugal, a ouvidoria da polícia (Inspecção-Geral da Administração Interna, IGAI) não tem competência para realizar investigações criminais, devendo remeter as queixas à Procuradoria-Geral da República, mas pode colaborar com os órgãos de investigação na obtenção de provas.

Incumbidos pelo Fórum Nacional de Ouvidores da Polícia de elaborar uma minuta de projeto de lei para criação de ouvidorias de polícia nos estados, Benedito Domingos Mariano e Julita Lemgruber incluíram, na enumeração das atribuições da ouvidoria, a possibilidade de "realizar investigações nos casos exemplares, em que julgar necessária apuração independente dos órgãos corregedores". ${ }^{91}$ Esta parece ser a opinião também de Jayme Eduardo Machado e José Francisco da Silva, ouvidores do Rio Grande do Sul e de Minas Gerais, respectivamente. ${ }^{92}$ Este último, contudo, afirma que considera mais adequado o modo de atuação da Auditoria Independente da Polícia de San José, na Califórnia, que acompanha as investigações conduzidas pelos órgãos de correição da polícia. ${ }^{93}$ Lá, o Independent Police Auditor não conduz suas próprias investigações, mas monitora a investigação das queixas conduzida pelos investigadores dos assuntos internos. Quando as investigações são completadas, a ouvidoria realiza uma auditoria para determinar se elas foram conduzidas de modo justo, objetivo e

\footnotetext{
${ }^{90}$ Os endereços das respectivas páginas na internet são: http://www.policeombudsman.org/index.cfm e http://www.icd.gov.za/.

${ }^{91}$ Ver Art. $2^{\circ}$ - VIII, do projeto de lei no ANEXO 1.

${ }^{92}$ Conforme relatado na Ata da IV $V^{a}$ Reunião do Fórum Nacional de Ouvidores da Polícia.

${ }^{93}$ Depoimento dado ao autor a 21 de outubro de 2005.
} 
completo. Para que a auditoria possa ser realizada de maneira satisfatória, contudo, é desejável que a ouvidoria tenha acesso irrestrito a toda evidência física, documental e testemunhal. Aos que criticam o fato das investigações não serem conduzidas por um órgão independente, a ouvidora da polícia de San José, Teresa Guerrero-Daley, responde que a polícia tem colaborado bastante e tem aceitado aderir aos padrões investigativos estritos supervisionados pelo ouvidoria para manter o direito de liderar a agência investigativa. [Guerrero-Daley, 2004]

$\mathrm{Na} \mathrm{V}^{\mathrm{a}}$ Reunião do Fórum Nacional de Ouvidores da Polícia, realizada em Belo Horizonte a 27 de junho de 2004, discutiu-se a viabilidade da aproveitar o convênio com a União Européia para patrocinar visitas dos ouvidores a outros países que possuem experiências de sucesso. Sugeriu-se a Irlanda do Norte, onde uma situação de violência policial muito grande foi modificada com a implantação da ouvidoria, e Portugal, que tem uma experiência de controle externo mais semelhante com a brasileira. $^{94}$

Em suma, há grande variedade de alternativas quanto ao poder investigativo das ouvidorias. Algumas realizam investigações de cada queixa que recebem, outras têm poder apenas para supervisionar as investigações feitas pela polícia. Algumas podem processar policiais, outras têm autoridade apenas para recomendar medidas disciplinares ou divulgar relatórios. Algumas têm acesso a todos os arquivos policiais, outras apenas a documentos públicos. Algumas só examinam casos individuais, e muitas ainda sofrem restrições quanto ao tipo de casos que podem examinar, outras se concentram principalmente em certos padrões de queixas e questões administrativas. [Stone, 2003]

A realização de investigações pelas ouvidorias acarreta a necessidade de manter uma equipe grande de investigadores profissionais, o que consome uma grande parte

\footnotetext{
${ }^{94}$ Conforme relatado na Ata da $V^{a}$ Reunião do Fórum Nacional de Ouvidores da Polícia.
} 
dos recursos financeiros. Na África do Sul, por exemplo, a diretora do Independent Complaints Directorate confirma que a maior parte do seu orçamento vai para o setor de investigações. [McKenzie, 2003] Deve-se levar em consideração, também, que não é fácil encontrar investigadores não-policiais com experiência suficiente para realizar investigações independentes e que tenham interesse em colaborar com a ouvidoria. A Irlanda do Norte contornou esta dificuldade recrutando policiais de várias localidades do Reino Unido para fazer as suas investigações independentes. Esta prática foi aceita porque os investigadores não eram vistos pela população como sendo da polícia da Irlanda do Norte. [Graham, 2003] É importante lembrar, contudo, que as ouvidorias que contam com uma equipe numerosa de investigadores entre os seus quadros devem manter um certo controle sobre os mesmos. Caso contrário, corre-se o risco de repetir em menor escala os problemas das instituições policiais. Na África do Sul, por exemplo, um investigador do Independent Complaints Directorate teve que ser afastado e denunciado criminalmente, pois havia sido aliciado pela polícia. [Phillips e Trone, 2002]

Um ponto muito importante e que não pode ser desprezado é a possibilidade sempre presente das ouvidorias levarem a resultados negativos sobre a eficácia operacional da polícia e sobre o moral dos policiais. [Brereton, 2000] De um ponto de vista institucional, a investigação das denúncias por uma instância interna, como as corregedorias, é preferível por não minar a confiança dos policiais no processo investigativo. Para os cidadãos que fazem denúncias às ouvidorias, a verdade é que pouco importa se estas são investigadas por instâncias internas ou externas, desde que o resultado lhes dê razão. Com efeito, o que move os denunciantes é o desejo de tornar conhecido das autoridades o episódio em que foram envolvidos, e que os responsáveis 
sejam punidos para evitar que as irregularidades se repitam. As sanções só podem ser aplicadas pelas autoridades administrativas ou determinadas pelos órgãos judiciais.

Mesmo com as variedades de desenhos institucionais entre elas, as agências de controle externo da atividade policial devem sua existência à descrença que a população deposita na apreciação e investigação das denúncias contra policiais pelos mecanismos internos da polícia. Segundo alguns autores, assim como o júri deve sua existência não ao fato de juízes não serem capazes de analisar uma questão e produzir um julgamento justo, mas ao fato de um corpo de jurados oferecer mais credibilidade para fazê-lo, as ouvidorias de polícia existem porque oferecem maior confiabilidade para a população do que as corregedorias. [Skolnick e Fyfe, 1993] O que está em jogo não é a competência, mas a credibilidade. A questão central não é, portanto, saber se as ouvidorias são capazes de realizar investigações de maneira mais eficiente que as corregedorias, mas saber se é possível recuperar a credibilidade das corregedorias. A razão de ser das ouvidorias não é culpabilizar os policiais infratores, mas contribuir para um policiamento mais respeitador dos direitos para fazer com que a população acredite mais na sua polícia. As ouvidorias têm um papel diferente das corregedorias.

Bayley enumera três razões para explicar por que acredita que as instâncias de investigação interna das agências policiais são melhores do que os controles externos. Em primeiro lugar, diz ele, o controle interno pode ser mais completo do que o externo, pois a polícia pode esconder qualquer coisa que quiser da investigação externa, de modo a fazer a investigação externa parecer insatisfatória. Em segundo lugar, ele sustenta que a regulação interna é completa, pois pode abranger o conjunto das atividades policiais, não apenas os casos mais sérios. Em terceiro lugar, o controle interno pode ser mais variado, sutil e diferenciado do que o externo, pois pode utilizar também mecanismos informais presentes na atividade policial. [Bayley, 2001] 
Faz-se necessário ressaltar que, mesmo que a legislação que instituiu a ouvidoria não lhe faculte o poder de realizar investigações formais, está sempre ao alcance do ouvidor a possibilidade de fazer investigações informais, para depois encaminhar os resultados da apuração aos órgãos competentes que vão proceder a uma investigação formal, como as corregedorias e o ministério público. Este é, precisamente, o ponto de vista de Fermino Fecchio que, à frente da ouvidoria da polícia de São Paulo, identificou por meio de investigações informais, grupos de extermínio formados por policiais em Ribeirão Preto e em Guarulhos:

“Pela lei, realmente, a ouvidoria não pode fazer prova, ela não pode investigar no sentido de construir uma prova judicial, porque a lei define quem faz, quem redige laudo. A ouvidoria não entra nestes casos. Mas a ouvidoria pode investigar a procedência ou não das denúncias que recebe. Se ela vê que tem elementos que comprovam os indícios da denúncia, ela formaliza a denúncia para os órgãos competentes, para o procurador geral, para quem quiser. Mesmo sem, formalmente, a lei dizer que ela pode investigar, ela pode fazer muita coisa."

Fermino Fecchio alerta para o perigo de engessar as atividades das ouvidorias se lhe forem atribuídas a incumbência das investigações, o que pode tirar-lhes muito da agilidade e da informalidade que as caracterizam:

“Tem muita gente que fica preocupada em definir se pode ou não investigar. Eles ficam preocupados com formalismos. A grande novidade da ouvidoria é o acesso rápido da população e outra coisa, pelo fato da ouvidoria não ser um contencioso, você não vai discutir ali quem tem razão, quem não tem razão. A ouvidoria ouve, encaminha, pede, examina. A ouvidoria não está sujeita às formalidades do processo. Ela não está sujeita a prazos. O risco das 
ouvidorias é se transformarem em departamentos jurídicos, com toda aquela burocracia. Ouvidoria não é pra isso. A ouvidoria não é uma repartição pública, não é um escritório de advocacia. Ela não é um centro de defesa dos direitos humanos jurídico. A ouvidoria tem que ser informal, ela tem que ser rápida, ela tem que dar uma satisfação ao cidadão rapidamente." 95

Uma capacidade de atuação muito importante das ouvidorias, e que talvez nenhum outro órgão de controle possa ter, é a possibilidade de ter uma visão de conjunto da atuação das forças policiais. Mais importante do que solucionar casos individuais, por mais relevantes que sejam, é verificar se são casos isolados ou se os eventos relatados se repetem com freqüência e em que circunstâncias. O próximo passo será tentar entender por que há um padrão de irregularidades que se repetem para, só então, elaborar sugestões no sentido de aperfeiçoar a atividade policial. Caso contrário, argumenta Fermino Fecchio, as ouvidorias acabam repetindo a forma de atuação da polícia, que fica esperando a vítima chegar na delegacia e age somente após o fato.

Para Fermino Fecchio, o controle eficaz da atividade policial não pode se limitar a acompanhar a correição dos procedimentos ilegais ou abusivos dos policiais. A sociedade precisa acompanhar também a gestão da segurança pública como um todo. Mas para isso, é preciso ter acesso às informações de planejamento da segurança, para que se possa verificar se os resultados alcançados estão de acordo com o que foi planejado. A exemplo do ouvidor da polícia de Los Angeles, seria interessante que os ouvidores da polícia no Brasil também tivessem acesso à execução orçamentária da polícia, ao quadro funcional e aos instrumentos de controle normativos. Nas palavras de Fermino Fecchio:

\footnotetext{
${ }^{95}$ Depoimento dado ao autor a 2 de junho de 2005.
} 
"Você tem que ter cópia do regulamento disciplinar da polícia militar. Os ouvidores têm que ter cópia da lei orgânica da polícia civil. Eles precisam acompanhar as resoluções, as portarias. Se não, eles não têm o que prescrever a um policial, pois não sabem se ele está agindo de acordo com a lei ou não.”

Seguindo o mesmo raciocínio, justamente por ter uma visão sistemática de como está agindo a polícia, as ouvidorias poderiam elaborar parâmetros da sociedade civil para medir o desempenho da polícia. Algumas questões que são lembradas com freqüência e poderiam ajudar a construir esses parâmetros são:

- $\quad$ verificação das condições em que se faz o policiamento, como por exemplo a questão das revistas e dos critérios que motivam a abordagem policial, [Ramos e Musumeci, 2005]

- $\quad$ investigar as condições de trabalho na polícia e o motivo pelo grande número de suicídios entre policiais,

- $\quad$ quanto à corrupção e ao comportamento violento de policiais, pode-se identificar se há regiões onde essas atitudes se concentram.

Essa visão das ouvidorias de polícia como órgãos que permitem uma melhor sistematização da atividade policial faz parte, aliás, dos objetivos do Comité $P$, na Bélgica, conforme explicitado na sua brochura de apresentação:

“A missão do Comité $P$ é principalmente verificar em que medida os responsáveis políticos poderiam ou deveriam aperfeiçoar o funcionamento dos serviços policiais, ou se a legislação relativa à atividade policial deve ser modificada. O controle não tem como finalidade principal constatar fatos individuais na atividade policial que merecem sanção: este papel permanece da inteira competência das autoridades judiciais, policiais e de disciplina. O objetivo essencial é examinar o funcionamento dos serviços policiais e relatar as 
imperfeições ou vícios de funcionamento do sistema, das estruturas, dos métodos, das intervenções policiais, e formular sugestões para os corrigir." [Comité P, 2003]

Dois bons exemplos de como as ouvidorias de polícia podem contribuir neste sentido, a partir de uma visão de conjunto que só é possível porque elas têm acesso a uma grande quantidade de denúncias, são a Pesquisa sobre o Uso da Força Letal por Policiais de São Paulo no Ano de 1999, realizada durante a gestão de Benedito Domingos Mariano, e a publicação Resistência Seguida de Morte: a apuração dos limites do uso da força letal no âmbito da Polícia Judiciária, do Ministério Público e do Poder Judiciário - uma abordagem processual, divulgada durante a gestão de Fermino Fecchio, ambas na Ouvidoria da Polícia de São Paulo.

A primeira pesquisa, na qual foram analisadas 193 ocorrências em que houve vítimas fatais revelou que de 474 policiais militares que participaram das ações, 7 foram mortos e 34 feridos. Ou seja, dentre os 41 atingidos, $17 \%$ dos policiais militares alvejados morreram enquanto que $83 \%$ ficaram feridos. ${ }^{96}$ Os números para a polícia civil são semelhantes: de 62 policiais civis alvejados, 2 foram mortos e 7 feridos, ou seja, $22 \%$ dos policiais civis morreram e $78 \%$ ficaram feridos. Com relação às vítimas civis, os números se invertem: de 365 civis, 236 foram mortos e 18 feridos, ou seja, entre as vítimas civis houve $93 \%$ de mortos e $7 \%$ de feridos. Quando se considera o total de vítimas fatais, $96 \%$ são civis e $4 \%$ são policiais. Ao comentar estes resultados, Benedito Domingos Mariano diz com ironia que "das duas uma, ou os policiais são muito bons de tiro, ou os bandidos não são tão perigosos quanto a polícia afirma". ${ }^{97} \mathrm{O}$ mais provável, contudo, é que ao invés de confrontos entre policiais e bandidos,

\footnotetext{
${ }^{96}$ Os resultados da pesquisa constam do Relatório Anual de Prestação de Contas 2000 da Ouvidoria da Polícia de São Paulo.

${ }^{97}$ Entrevista concedida ao autor.
} 
conhecidas nos meios policiais pelo eufemismo "resistência seguida de morte", trate-se de execuções sumárias. Com efeito, a mesma pesquisa revela que:

- $\quad$ do total de ocorrências pesquisadas, em $44 \%$ não havia testemunhas,

- $\quad$ dos civis mortos, $56 \%$ não tinham antecedentes criminais, sendo $11 \%$ menores de idade,

- $\quad$ das vítimas civis, em 51\% delas havia perfurações nas costas, sendo $11 \%$ menores,

- $\quad 36 \%$ das vítimas apresentaram perfurações de arma de fogo na cabeça, 19\% das vítimas apresentaram perfurações de arma de fogo só nas costas.

Uma conseqüência direta desta pesquisa foi a constituição, a 26 de dezembro de 2000, pelo Secretário da Segurança Pública Marcus Vinicius Petreluzzi, da Comissão Especial para Redução da Letalidade em Ações envolvendo Policiais. O objetivo da comissão era reduzir a letalidade da ação policial dos dois lados, e a sua composição incluía integrantes das forças policiais (Gabinete da Secretaria de Segurança Pública, da Polícia Militar, da Polícia Civil, e da Superintendência da Polícia Técnico Científica) e três representantes da sociedade civil: Ouvidoria da Polícia (Isabel Seixas de Figueiredo), Núcleo de Estudos da Violência da Universidade de São Paulo - NEV/USP (Luiz Antônio Francisco de Souza), e Instituto São Paulo contra a Violência (Paulo de Mesquita Neto). Os resultados da criação da comissão são difíceis de ser avaliados, pois ela foi extinta no início de 2002, quando Saulo de Castro Abreu Filho assumiu a Secretaria da Segurança Pública.

Na segunda pesquisa, a ouvidoria da polícia de São Paulo constatou que vários casos de homicídios praticados por policiais civis e militares não são submetidos à devida apreciação pelo Poder Judiciário. Em muitos casos, os inquéritos policiais 
instaurados para apurar os fatos levam em conta apenas os atos relativos à vítima do homicídio, sem contestar a legalidade ação policial. Em outras palavras, a vítima é considerada culpada por ter morrido, com a agravante dos seus antecedentes criminais, se houverem. Como os casos são classificados como "resistência seguida de morte", ao passarem pela distribuição informatizada do Poder Judiciário eles não são distribuídos às varas do Júri, mas sim às varas criminais comuns, pois o crime de resistência não é um crime doloso contra a vida. A pesquisa mostra que o índice de oferecimento de denúncias foi de $93,7 \%$ quando se tratou de processar "comparsas" da vítima fatal, e de apenas $12,8 \%$ quando se tratou de processar criminalmente policiais autores de homicídios. Outro resultado da pesquisa é que apenas $61,3 \%$ dos inquéritos policiais chegaram ao seu destino legalmente determinado: a Vara do Júri. Após tomar conhecimento da pesquisa, em junho de 2002, o Procurador Geral de Justiça do Estado de São Paulo, Luiz Antônio Guimarães Marrey, e o Corregedor Geral de Justiça do Estado de São Paulo, Desembargador Luiz Tâmbara, determinaram que os autos dos inquéritos policiais em que constasse um homicídio cometido por policial, mesmo que tipificado como "resistência seguida de morte", fossem corretamente remetidos e apreciados nas varas do Júri. ${ }^{98}$

Outras conquistas significativas atribuídas à ouvidoria da polícia de São Paulo são:

Mudança da silhueta de tiro na Academia da Polícia Civil: Com o objetivo de incentivar o tiro preventivo, a Ouvidoria da Polícia do Estado de São Paulo propôs um modelo de silhueta de tiro de corpo inteiro, dando maior pontuação para os tiros que atingissem os braços, as pernas e os ombros, e não as partes letais do corpo, como era antes,

\footnotetext{
${ }^{98}$ Trata-se do Aviso $\mathrm{n}^{\circ} 460$ do Procurador Geral de Justiça do Estado, publicado no Diário Oficial do Estado de São Paulo de 06/07/2002, e do Provimento no 14/2002 do Corregedor Geral de Justiça do Estado, publicado no Diário Oficial do Estado de São Paulo de 01/08/2002.
} 
quando a silhueta representava apenas um busto humano. A partir de 1999, a nova silhueta foi adotada, tanto na Academia da Polícia Civil, quanto na Polícia Militar.

Inclusão de uma disciplina de direitos humanos da Academia da Polícia Civil: A Ouvidoria da Polícia do estado de São Paulo propôs a criação de uma disciplina permanente sobre direitos humanos na Academia da Polícia Civil. A proposta foi aceita e, no primeiro concurso público interdisciplinar organizado pela Academia, foram selecionados dez novos professores sendo que a metade não faz parte dos quadros da polícia.

Com o intuito de melhorar as condições de trabalho dos policiais e aperfeiçoar os órgãos policiais, o Fórum Nacional de Ouvidores de Polícia elaborou uma Proposta de Emenda Constitucional para um Novo Modelo de Polícia no Brasil, que extingue as polícias civis e militares e propõe uma estrutura unificada, denominada Polícia Estadual, com vocação para o exercício integral das funções policiais. O projeto prevê também uma remodelagem da estrutura policial, com o estabelecimento de apenas cinco graus hierárquicos, com a remuneração máxima não excedente a mais de quatro vezes a mínima, e um regime disciplinar mais adequado e compatível com a natureza da função policial.

No mesmo sentido, Benedito Domingos Mariano ajudou na elaboração de um novo regulamento disciplinar para a Brigada Militar do Rio Grande do Sul que abriu a possibilidade de uma segunda atividade para os policiais militares, desde que não haja prejuízo do serviço ou emprego de meios do Estado, e extinguiu as punições de prisão e detenção administrativas. Aliada aos baixos salários, a rigidez das normas das Polícias 
militares é apontada por vários autores como um dos fatores de insatisfação da tropa e da violência policial. O objetivo principal de regulamentar a segunda atividade é permitir que aos policiais complementar a sua renda, desde que não trabalhem como vigilantes particulares, quando enfrentam maiores riscos de serem mortos. Nas palavras Luiz Goulart Filho, ouvidor da justiça e da segurança do Rio Grande do Sul e um dos autores do novo regulamento, "o bico tem sido tolerado institucionalmente, embora proibido pela Constituição, e moralmente pode ser defendido por ser a conseqüência de uma situação de necessidade". 99

O novo regulamento disciplinar para a Brigada Militar do Rio Grande do Sul estabelece também o fim da prisão administrativa que são uma particularidade dos regulamentos disciplinares das polícias militares que reproduzem os do exército brasileiro. A maioria das cerca de 40 transgressões disciplinares previstas diz respeito a problemas da caserna, como:

- $\quad$ necessidade de autorização para se casar,

- $\quad$ vagar ou passear pelas ruas após as 22 horas, sem permissão escrita da autoridade competente,

- $\quad$ deixar, quando estiver sentado, de oferecer seu lugar a um superior em qualquer situação,

- $\quad$ não estar com a farda devidamente passada.

Muitas das transgressões têm como punição prisões administrativas, que vão de 5 a 30 dias de detenção. A experiência mostra que o desrespeito a questões internas

\footnotetext{
${ }^{99}$ Alguns meses antes da sanção do novo regulamento, uma policial militar gaúcha causou frisson ao declarar em entrevista à Rádio Gaúcha, em julho de 2001, que trabalhava como dançarina em casas noturnas para complementar o seu salário e era acompanhada por outras colegas: "Sou dançarina, de onde consigo sobreviver com meus filhos. Tiro em torno de $\mathrm{R} \$ 1.500$ mensais, às vezes tiro $\mathrm{R} \$ 2.000$, por causa das gorjetas". Outro policial afirmou que "a gente é muito mais reconhecido num bico do que na própria Brigada Militar".
} 
definidas por regulamentos arcaicos ${ }^{100}$ é punido de forma muito mais dura do que se o policial cometer crimes nas ruas ou desrespeitar, e até ameaçar, a vida dos cidadãos que deveria proteger. [Mariano, 1997 e 1999]

Esses exemplos mostram bem que, no convívio cotidiano com as demandas e queixas da população, a respeito das polícias civil e militar, as ouvidorias vêm elaborando um diagnóstico dos problemas estruturais e conjunturais das polícias.

\footnotetext{
${ }^{100}$ O regulamento da Polícia Militar do Estado de São Paulo, por exemplo, data de 1943, quando só existia a força pública, uma espécie de "exército regional paulista" que não tinha função de polícia preventiva e ostensiva. [Mariano, 1997]
} 


\section{Considerações Finais}

Nas sociedades democráticas, a polícia deve prestar contas de muitos aspectos do seu trabalho. Oficialmente, a polícia é responsável pela eficácia na luta contra o crime e os distúrbios da ordem. Estes objetivos, contudo, devem ser atingidos com profissionalismo e respeito das leis e dos cidadãos. Todo o cuidado é pouco quando se trata de controlar a polícia, pois a atividade policial pressupõe uma dose razoável de arbítrio. Diante da impossibilidade de verificar todas as infrações possíveis às leis, o policial na rua tem um papel decisivo na escolha dos comportamentos a serem monitorados. Uma instituição policial democrática deve prestar contas a vários atores, que podem ser o governador e o secretário de segurança pública, o legislativo, o judiciário, o ministério público, os cidadãos que buscam a sua ajuda e a sociedade como um todo através da imprensa e de organizações da sociedade civil. Neste trabalho, nos limitamos a examinar os mecanismos de controle externo da polícia por meio das ouvidorias e pretendemos ter mostrado como se trata de uma experiência importante para a construção de uma sociedade mais democrática, em que os cidadãos não se limitem a votar periodicamente e a esperar que os eleitos façam todo o resto.

Em outras palavras, tentamos responder à seguinte pergunta: "qual é o impacto que causa a instalação de uma ouvidoria de polícia?”. Ao nosso ver, três pontos são importantes: a informação, a participação, e o controle. A informação sobre o funcionamento da polícia é um ponto fundamental, e do qual depende muito este trabalho, pois é a partir da instalação das ouvidorias de polícia que foi possível aos que não fazem parte da carreira policial conhecer o que acontece dentro das delegacias de polícia, ou de que maneira são planejadas e efetivadas as ações da polícia militar, ou ainda quais são os critérios de punição e manutenção da disciplina no interior das 
corporações policiais. A participação é outro dado fundamental, pois é o que faz das ouvidorias mecanismos de participação popular. Por fim, o controle que é exercido sobre a polícia por uma ouvidoria permite que a sociedade se torne vigilante daqueles cuja profissão é vigiar-nos.

Veja-se, por exemplo, o seguinte texto, produzido pela ouvidoria da polícia de São Paulo, a respeito do caso do Gradi:

"A falta de transparência e as dúvidas sobre a legalidade dos métodos utilizados pelos policiais militares do Gradi servem como alerta para que nos voltemos a uma questão mais ampla: o controle social da segurança pública. É importantíssimo que a população conheça sua polícia, suas ações e - mais do que isso - o resultado concreto de sua atuação, o que implica ter clareza, por exemplo, sobre o número de crimes solucionados. A tão apontada necessidade de controle externo da atividade policial, que deveria ser realizado pelo Ministério Público e pelo Poder Judiciário, emerge novamente: em um Estado Democrático de Direito a polícia não pode ser um Estado à parte, com métodos, valores e regras próprias."

Podemos, agora, fazer uma síntese das conquistas, dificuldades e desafios que são resultado da dedicação dos ouvidores da polícia. Deve-se lembrar, contudo, que é muito difícil medir o alcance efetivo de uma ouvidoria. Esta dificuldade se deve, em parte, ao fato de haver efeitos simbólicos e efeitos práticos, como resultado da instalação de uma ouvidoria.

No plano das conquistas, é preciso mencionar o relacionamento com o público e a grande vantagem da informalidade que torna mais acessíveis a burocracia e a máquina estatal. Neste sentido, é interessante o testemunho do ouvidor da polícia do Paraná de

\footnotetext{
${ }^{101}$ Ver relatório de atividades relativo ao ano de 2002 da Ouvidoria da Polícia do Estado de São Paulo.
} 
que as pessoas procuram a ouvidoria até para denunciar crimes comuns porque a ouvidoria dá retorno. Este exemplo mostra que "dar voz" ao povo pode ter efeitos inesperados, e podemos lembrar aqui os "cahiers de doléances" da Revolução Francesa, nos quais os cidadãos podiam inscrever suas queixas e solicitações, e que serviram de subsídios para os deputados redigirem a Declaração de Direitos do Homem e do Cidadão, em 1789, e a Constituição, em 1791.

Neste sentido, talvez a maior conquista representada pela instalação das ouvidorias de polícia seja ter permitido um maior conhecimento sobre a polícia e o que acontece no interior das corporações policiais:

"Ao incentivar os civis a darem queixa quando for o caso, e ao facilitar ao máximo este processo, mantendo-o, contudo, formal e detalhado, os órgãos de controle externo podem obter muitíssimas informações sobre a maneira como a polícia realmente lida com as pessoas em sua interação cotidiana. Baseando-se nas queixas, esses órgãos devem então se dedicar à elaboração de relatórios que permitam que os comandantes, outros funcionários do governo e o público se dêem conta de situações-padrão que podem ser sistematicamente tratadas." [Stone, 2003]

No plano das dificuldades, um grande obstáculo ao funcionamento adequado das ouvidorias é o seu relacionamento ambíguo com os governos estaduais, pois, ao mesmo tempo que estão formalmente subordinadas a eles, sua missão é criticar e apontar os desvios e as irregularidades da polícia, controlada diretamente pelos governadores.

Uma conseqüência desta falta apoio se manifesta em toda sorte de dificuldades materiais e, principalmente, na divulgação ainda muito deficiente das atividades das ouvidorias. 
Quanto ao poder de investigação das ouvidorias, alguns são favoráveis, pois aumenta o poder de fogo e a independência das ouvidorias e evita que não haja punição. No limite, porém, significaria criar ouvidorias com poder de polícia.

Outros são contra e argumentam que haveria o risco de burocratizar em excesso as ouvidorias e sobrecarregá-las: ter poder de investigação significa ter que cumprir prazos e determinações legais, e tira muito da vantagem que as ouvidorias têm que é a rapidez de resposta e a informalidade. Sempre há a possibilidade, argumentam os defensores dessa posição de realizar investigações paralelas e transmitir os resultados ao Ministério Público.

Percebe-se que há dois parceiros institucionais fundamentais das ouvidorias: as corregedorias e o Ministério Público. A experiência mostra, contudo, que as corregedorias e o Ministério Público precisam se adaptar às ouvidorias e ao fluxo crescente de denúncias.

A comparação entre as ouvidorias existentes no Brasil mostra que o perfil do ouvidor influencia decisivamente no sucesso e na visibilidade de uma ouvidoria de polícia e pode se refletir, inclusive, na quantidade de denúncias recebidas mensalmente. Isto significa que as ouvidorias de polícia ainda estão fracamente institucionalizadas. Pelo fato das ouvidorias estarem ligadas ao executivo, o apoio do governador é decisivo para que os ouvidores possam trabalhar com eficiência. Finalmente, acreditamos que, para que a experiência das ouvidorias continue a frutificar e ganhar cada vez mais adeptos na sociedade é preciso que elas não se contentem em ouvir, mas mostrem com maior freqüência o resultado do seu trabalho. Em outras palavras, as ouvidorias têm que se transformar também em "faladorias". Neste sentido, são especialmente felizes os títulos de duas publicações da Ouvidoria da Polícia de Minas Gerais: A Ouvidoria Agora Vai Falar e A Ouvidoria de Polícia de Minas Gerais Mostra o Que Faz. 


\section{Anexos}

6.1 Minuta de Projeto de Lei para a criação de ouvidorias da polícia nos estados, elaborada Fórum Nacional de Ouvidores da Polícia no seu IV ${ }^{\mathrm{o}}$ encontro, realizado nos dias $1^{\circ}$ e 2 de outubro de 2003.

6.2 Roteiro para a recepção de denúncias de desvio policial na Ouvidoria da Polícia de Minas Gerais

6.3 Evolução dos critérios de avaliação das irregularidades na atividade policial na Ouvidoria da Polícia de São Paulo

6.4 Pesquisa sobre a disponibilidade da informação do telefone da Ouvidoria da Polícia de São Paulo junto às delegacias de polícia da grande São Paulo

6.5 Pesquisa sobre a disponibilidade da informação do telefone da Ouvidoria da Polícia de São Paulo junto aos batalhões da polícia militar da grande São Paulo

6.6 Exemplares $\mathrm{n}^{\mathrm{o}} 3$ e $^{\circ} 4$ e edição extra E2 do jornal eletrônico Otite Crônica, idealizado por Fermino Fecchio quando esteve à frente da Ouvidoria da Polícia do Estado de São Paulo, com o objetivo de romper o cerco em que foi colocado pelo governo do estado. 


\begin{abstract}
ANEXO 1
MINUTA DE PROJETO DE LEI

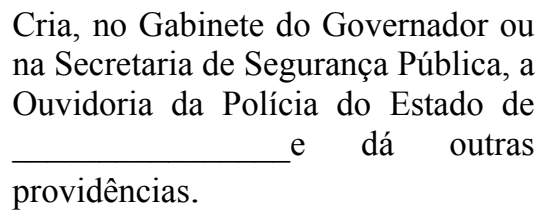

, Governador (a) do Estado de , no uso das atribuições que the são conferidas por lei, faz saber que a Assembléia Legislativa, em sessão de , decretou e eu promulgo a seguinte lei:

Art. $1^{\mathbf{0}}$ - Fica criada, junto ao Gabinete do Governador ou do Secretário de Segurança Pública, a Ouvidoria da Polícia do Estado de órgão independente, com autonomia administrativa, orçamentária e funcional, tendo por objetivo assegurar, de modo permanente e eficaz, a preservação dos princípios de legalidade, moralidade e eficiência dos atos dos agentes policiais (e penitenciários) do Estado.

Art. $2^{\circ}$ - A Ouvidoria da Polícia tem as seguintes atribuições:

I - Receber e apurar denúncias, reclamações e representações sobre atos considerados ilegais, arbitrários, desonestos, indecorosos, que contrariem o interesse público, ou que violem os direitos humanos individuais ou coletivos, praticados por servidores civis e militares (assim como agentes penitenciários) da Secretaria de Segurança Pública;

II - Receber sugestões sobre o funcionamento dos serviços policiais;

III - Receber sugestões de servidores civis e militares da Secretaria da Segurança Pública sobre o funcionamento dos serviços policiais, bem como denúncias a respeito de atos irregulares praticados na execução desses serviços, inclusive por superiores hierárquicos;

IV - Realizar diligências nas unidades policiais, sempre que necessário para o desenvolvimento de seus trabalhos;

V - Proceder auditorias e correições preliminares nos órgãos policiais;

VI - Manter sigilo, quando solicitado, sobre denúncias e reclamações, bem como sobre sua fonte, providenciando, junto aos órgãos competentes, proteção aos denunciantes;

VII - Manter serviço telefônico gratuito, destinado a receber denúncias e reclamações; 
VIII - Realizar investigações nos casos exemplares, em que julgar necessária apuração independente dos órgãos corregedores;

IX - Manter arquivo atualizado de documentação relativa às reclamações, denúncias e representações recebidas;

$\mathrm{X}$ - Promover estudos, propostas e gestões, em colaboração com os demais órgãos do Estado, objetivando aprimorar o funcionamento dos órgãos policiais;

XI - Elaborar e publicar, trimestral e anualmente, relatório de suas atividades;

XII - Realizar seminários, pesquisas e cursos versando sobre assuntos de interesse da segurança pública e sobre temas ligados aos direitos humanos, divulgando os resultados desses eventos;

XIII - Dar conhecimento, sempre que solicitado, das denúncias, reclamações e representações recebidas pela Ouvidoria ao Governador do Estado, ao Secretário da Segurança Pública e aos membros do Conselho Consultivo;

XIV - Encaminhar às Comissões de Segurança Pública e Direitos Humanos da Assembléia Legislativa, anualmente, cópia do relatório mencionado no inciso deste artigo.

Art. $3^{\mathbf{0}}$ - Compete ao Ouvidor da Polícia:

I - Propor aos órgãos do Estado, resguardadas as respectivas competências, a instauração de sindicâncias, inquéritos e outras medidas destinadas à apuração de responsabilidade administrativa, civil e criminal, fazendo à Polícia Civil ou ao Ministério Público ou ainda ao Poder Judiciário as devidas comunicações, quando houver indício ou suspeita de crime;

II - Requisitar, diretamente e sem qualquer ônus, de qualquer órgão estadual, informações, certidões, cópias de documentos ou volumes de autos relacionados com investigações em curso;

III - Recomendar a adoção de providências que entender pertinentes, necessárias ao aperfeiçoamento dos serviços prestados à população pela Polícia Civil, pela Polícia Militar e por outros órgãos da Pasta;

IV - Recomendar aos órgãos do Estado a adoção de mecanismos que dificultem e impeçam a violação do interesse público, dos direitos humanos e outras irregularidades comprovadas;

V - Celebrar termos de cooperação com entidades públicas ou privadas nacionais, que exerçam atividades congêneres às da Ouvidoria;

Art. $4^{\mathbf{0}}$ - A Ouvidoria da Polícia será dirigida por um Ouvidor da Polícia, que gozará de autonomia e independência, indicado em lista tríplice pelo Conselho Estadual de Defesa dos Direitos da Pessoa Humana e nomeado pelo Governador, para um mandato de dois ou três anos; 
$\S 1^{\circ}$ - O Ouvidor da Polícia poderá ser reconduzido ao cargo uma única vez, por igual período, também mediante indicação em lista tríplice elaborada pelo Conselho Estadual de Defesa dos Direitos da Pessoa Humana.

$\S 2^{\circ}$ - O cargo de Ouvidor da Polícia será exercido em jornada completa de trabalho, vedado o exercício de qualquer outra atividade remunerada, com exceção do magistério.

$\S 3^{\circ}$ - O Ouvidor da Polícia somente poderá ser destituído por iniciativa do Governador, desde que tal ato seja fundamentado, em decorrência de conduta incompatível com o exercício do cargo, devidamente comprovada, com a anuência do Conselho Estadual de Defesa dos Direitos da Pessoa Humana, por deliberação da maioria absoluta dos seus membros, ouvido previamente o Conselho Consultivo da Ouvidoria da Polícia.

Art. $5^{0}$ - A Ouvidoria da Polícia compreende:

I - Gabinete do Ouvidor;

II - Assessoria Técnica;

III - Assistência Administrativa;

IV - Assistência Civil e Militar;

V - Conselho Consultivo.

$\S 1^{\circ}$ - O Ouvidor da Polícia será substituído, nos seus impedimentos, pelo seu Chefe de Gabinete.

$\S 2^{\circ}$ - O Assistente Civil e Assistente Militar serão indicados pelo Ouvidor ao Governador.

$\S 3^{\circ}$ - A Ouvidoria deverá ter, no mínimo, vinte cargos em comissão, que serão preenchidos mediante prévia indicação do Ouvidor de Polícia.

Art. $6^{0}$ - Aplica-se ao cargo de Ouvidor da Polícia a referência "OP”, que fica instituída com valor correspondente à

Art. $7^{\mathbf{0}}$ - Para provimento do cargo de Ouvidor da Policia exigir-se-á:

a. Estar em gozo de seus direitos políticos;

b. Ter, no mínimo, 35 (trinta e cinco) anos de idade, quando da investidura.

Parágrafo único - O Ouvidor da Polícia não poderá ter qualquer vínculo com a Polícia Civil ou com a Polícia Militar.

Art. $8^{\mathbf{0}}$ - O cargo de Ouvidor da Polícia terá o mesmo nível hierárquico, as mesmas prerrogativas e atribuições do cargo de Secretário Estadual.

Art. $9^{0}$ - Para a consecução de seus objetivos a Ouvidoria da Polícia atuará:

I - Em decorrência de denúncias, reclamações e representações de qualquer do povo e ou de entidades representativas da sociedade; 
II - Por solicitação do Governador e dos Secretários Estaduais;

III - Por iniciativa própria;

Parágrafo único - A Ouvidoria da Polícia poderá instalar núcleos de atendimento nos municípios.

Art. $\mathbf{1 0}^{\mathbf{0}}$ - O Conselho Consultivo da Ouvidoria da Polícia do Estado de_ será composto por 11 (onze) membros, incluído na qualidade de membro nato o Ouvidor da Polícia, que presidirá o Colegiado.

$\S 1^{\circ}$ - Os demais membros do Conselho serão designados pelo Governador ou pelo Secretário de Segurança Pública, entre pessoas indicadas pelo Ouvidor, para um mandato de dois anos, admitida recondução por igual período.

$\S 2^{\circ}$ - Os membros de que trata o parágrafo anterior poderão ser destituídos, a qualquer tempo, mediante decisão fundamentada do Governador ou do Secretário de Segurança Pública, ouvido o Conselho Estadual de Defesa dos Direitos da Pessoa Humana.

$\S 3^{\circ}$ - As normas de funcionamento do Conselho Consultivo serão estabelecidas em regimento interno.

$\S 4^{\circ}$ - As funções de membro do Conselho não serão remuneradas, sendo, porém, consideradas de serviço público relevante.

Art. $1^{\circ}$ - A Ouvidoria da Polícia terá sede própria, distinta das instalações da Secretaria de Segurança estadual.

Art. $1^{\circ}$ - Os atos oficiais da Ouvidoria da Polícia serão publicados no Diário Oficial do Estado, em espaço próprio reservado ao órgão.

Art. $\mathbf{1 3}^{\mathbf{0}}$ - Para atender às despesas decorrentes desta lei no presente exercício, fica o Executivo autorizado, a abrir créditos adicionais especiais, até o valor de $\mathrm{R} \$$ , nos termos do artigo 43 da Lei Federal no 4320, de 17 de março de 1964.

$\S 1^{\circ}$ - Nos exercícios subseqüentes as despesas com a execução desta Lei correrão por conta de dotações orçamentárias próprias, suplementadas se necessário.

Art. $1^{0}$ - O Poder Executivo providenciará a disponibilização dos imóveis, móveis, veículos e servidores solicitados pela Ouvidoria da Polícia, destinados ao cumprimento de suas funções.

Art. $\mathbf{1 5}^{\mathbf{0}}$ - Esta lei entrará em vigor na data de sua publicação, revogadas as disposições em contrário. 


\section{ANEXO 2 \\ Roteiro para a recepção de denúncias de desvio policial na Ouvidoria da Polícia de Minas Gerais}

\section{Perfil do denunciante}

O primeiro aspecto a se observar consiste em verificar se o denunciante é pessoa física ou jurídica. Na primeira hipótese, proceder ao seguinte questionário:

- É vítima?

- Em caso negativo, tem algum parentesco com a vítima?

- Autoriza sua identificação?

- Encaminhou a denúncia a outro órgão? Em caso positivo, especificá-lo.

- Veio orientado por algum órgão? Em caso positivo, especificá-lo.

- Como tomou conhecimento da Ouvidoria?

- Como contatou a Ouvidoria (pessoalmente, telefone, documento (carta, ofício institucional), telefone, internet, de ofício, não-informado)?

- Qual a nacionalidade?

- Qual a naturalidade (município e estado)?

- Qual o sexo (masculino, feminino, não informado)?

- Qual o estado civil (casado, solteiro, amasiado, separado judicialmente, divorciado, viúvo, não-informado)?

- Qual a escolaridade (analfabeto, $1^{\circ}$ grau incompleto, $1^{\circ}$ grau completo, $2^{\circ}$ grau incompleto, $2^{\circ}$ grau completo, $3^{\circ}$ grau incompleto, $3^{\circ}$ grau completo, não-informado)?

- Qual a profissão (policial civil ou militar, funcionário público, estudante, do lar, aposentado, desempregado, outras profissões, não-informado)?

- Qual a cor da pele (branca, preta, negra, parda, amarela, indígena, nãoinformada)?

- Qual a renda (sem renda, 01 salário mínimo, 2 a 5 salários mínimos, 6 a 10 salários mínimos, acima de 10 salários mínimos, não-informado)?

- Qual o município e estado em que reside (endereço completo e telefone, se possível)? 


\section{Perfil da denúncia}

- Refere-se a policiais civis, militares ou a ambos?

- Qual a data e horário dos fatos (dia, mês, ano e hora aproximada)?

- Qual a região dos fatos (capital, região metropolitana, interior)?

- Qual o município dos fatos?

- Qual o lugar dos fatos (rua, rua/unidade policial, residência, residência/unidade policial, estabelecimento, estabelecimento/unidade policial, unidade policial, não-informado)?

- Quais as naturezas dos fatos (vide codificação das naturezas)?

- Sofreu violência física?

Importante observar que, quando da adequação das naturezas aos fatos alegados, havendo notícia de que a vítima foi vítima de violência física, se a mesma ainda não foi submetida a exame de corpo de delito, tal providência deverá ser cumprida o quanto antes. Ainda a propósito, vale destacar que somente ao perito médico-legista caberá avaliar eventuais vestígios de lesão corporal.

\section{Perfil dos denunciados}

- Os denunciados são policiais civis ou militares?

- Qual o número de policiais envolvidos?

- Quais os nomes e/ou alcunhas dos policiais denunciados (discriminar por corporação, quando for o caso)?

- Qual o cargo (1) ou posto/graduação (2) dos policiais denunciados?

- Qual a lotação dos policiais denunciados?

(1) Cargo se refere às carreiras da Polícia Civil.

(2) Posto e graduação se referem, respectivamente, aos oficiais ou praças da Polícia Militar. 


\section{Histórico}

Quanto a este item, deverão ser indagados todos os dados elementares que permitirão a verificação de autoria dos fatos alegados, a saber:

\subsection{Denunciado policial civil:}

- Trajava colete ou qualquer outra espécie de identificação?

- Qual sua descrição física?

- O denunciante tem condições de fazer o reconhecimento do denunciado?

- Quais as características da viatura em que eventualmente estava (marca/modelo, cor e placa);

- Qual o tipo de arma/equipamento portada e/ou utilizados pelo policial (arma curta, arma longa)?

- O denunciado trabalha ou freqüenta rotineiramente o local (precisar os horários mais comuns)?

- O denunciado utilizava outro meio de transporte (cavalos, bicicletas, barcos, helicóptero)?

- O denunciante tem condições de identificar precisamente o autor do ilícito (na hipótese de existirem vários policiais no local)?

- O denunciado chegou ao local primeiro, chegou depois, obedecia a ordens ou comandava?

\subsection{Denunciado policial militar:}

- Qual o tipo de uniforme (boné branco, quepe, boina, bota de cano médio, bota de cano longo, identificação de insígnias no ombro ou manda da camisa, tarjeta)?

- Qual sua descrição física?

- O denunciante tem condições de fazer o reconhecimento do denunciado? 
- Quais as características da viatura em que eventualmente estava (marca/modelo, cor e placa)?

- Qual o tipo de arma/equipamento portada e/ou utilizados pelo policial (arma curta, arma longa, cassetete, tonfa)?

- O denunciado trabalha ou freqüenta rotineiramente o local (precisar os horários mais comuns)?

- O denunciado utilizava outro meio de transporte (cavalos, bicicletas, barcos, helicóptero)?

- O denunciante tem condições de identificar precisamente o autor do ilícito (na hipótese de existirem vários policiais no local)?

- O denunciado chegou ao local primeiro, chegou depois, obedecia ordens ou comandava?

Por derradeiro, importante frisar que, sejam civis ou militares os policiais denunciados, se o denunciante não souber precisar o número de envolvidos nos fatos, dever-se-á considerar o quantum como indeterminado. 


\section{ANEXO 3}

Evolução dos critérios de avaliação das irregularidades na atividade policial na

Ouvidoria da Polícia de São Paulo de 1996 a 2005 


\begin{tabular}{|c|c|c|c|c|}
\hline 1996 & 1997 & 1998 & 1999 & 2000 \\
\hline \multicolumn{5}{|c|}{ Violência } \\
\hline Abuso de autoridade & Abuso de autoridade & Abuso de autoridade & Abuso de autoridade & Abuso de autoridade \\
\hline Espancamento/Tortura & Espancamento/Tortura & Espancamento/Tortura & Espancamento/Tortura & Espancamento/Tortura \\
\hline Ameaça & Ameaça & Ameaça & Ameaça & Ameaça \\
\hline \multirow[t]{2}{*}{ Homicídio } & $\begin{array}{l}\text { Homicídio cometido } \\
\text { por policial }\end{array}$ & $\begin{array}{l}\text { Homicídio cometido } \\
\text { por policial }\end{array}$ & \multirow[t]{2}{*}{$\begin{array}{l}\text { Homicídio cometido } \\
\text { por policial }\end{array}$} & \multirow[t]{2}{*}{$\begin{array}{l}\text { Homicídio cometido } \\
\text { por policial }\end{array}$} \\
\hline & $\begin{array}{l}\text { Homicídio cometido } \\
\text { por particular }\end{array}$ & $\begin{array}{l}\text { Homicídio cometido } \\
\text { por particular }\end{array}$ & & \\
\hline & & $\begin{array}{l}\text { Tentativa de } \\
\text { homicídio por policial }\end{array}$ & $\begin{array}{l}\text { Tentativa de } \\
\text { homicídio por policial } \\
\end{array}$ & $\begin{array}{l}\text { Tentativa de } \\
\text { homicídio por policial } \\
\end{array}$ \\
\hline & & Agressão & Agressão & Agressão \\
\hline & & & Maus tratos & \\
\hline \multicolumn{5}{|c|}{ Corrupção } \\
\hline & $\begin{array}{l}\text { Tráfico de drogas } \\
\text { praticado por policial }\end{array}$ & $\begin{array}{l}\text { Tráfico de drogas } \\
\text { praticado por policial }\end{array}$ & $\begin{array}{l}\text { Tráfico de drogas com } \\
\text { participação de } \\
\text { policial }\end{array}$ & $\begin{array}{l}\text { Tráfico de drogas com } \\
\text { participação de } \\
\text { policial } \\
\end{array}$ \\
\hline Extorsão & Extorsão/Concussão & Extorsão/Concussão & Concussão & Concussão \\
\hline Prevaricação & Prevaricação & Prevaricação & Prevaricação & Prevaricação \\
\hline \multirow[t]{7}{*}{ Corrupção } & Corrupção & Corrupção passiva & Corrupção & Corrupção \\
\hline & Enriquecimento ilícito & Enriquecimento ilícito & Enriquecimento ilícito & Enriquecimento ilícito \\
\hline & Peculato & Peculato & Peculato & Peculato \\
\hline & Estelionato & Estelionato & Estelionato & Estelionato \\
\hline & & & Facilitação de fuga & Facilitação de fuga \\
\hline & & & $\begin{array}{l}\text { Roubo de carga com } \\
\text { participação de } \\
\text { policial }\end{array}$ & $\begin{array}{l}\text { Roubo de carga com } \\
\text { participação de } \\
\text { policial }\end{array}$ \\
\hline & & & & \begin{tabular}{|l|} 
Crime contra o \\
consumidor
\end{tabular} \\
\hline \multicolumn{5}{|c|}{ Irregularidades administrativas } \\
\hline $\begin{array}{l}\text { Qualidade do } \\
\text { atendimento }\end{array}$ & $\begin{array}{l}\text { Qualidade do } \\
\text { atendimento }\end{array}$ & \begin{tabular}{|l|} 
Qualidade do \\
atendimento
\end{tabular} & $\begin{array}{l}\text { Qualidade do } \\
\text { atendimento }\end{array}$ & $\begin{array}{l}\text { Qualidade do } \\
\text { atendimento }\end{array}$ \\
\hline Falta de policiamento & Falta de policiamento & Falta de policiamento & Falta de policiamento & Falta de policiamento \\
\hline Ponto de droga & $\begin{array}{l}\text { Tráfico de drogas } \\
\text { praticado por } \\
\text { particular }\end{array}$ & $\begin{array}{l}\text { Solicitação de } \\
\text { intervenção em ponto } \\
\text { de drogas }\end{array}$ & $\begin{array}{l}\text { Solicitação de } \\
\text { intervenção em ponto } \\
\text { de drogas }\end{array}$ & $\begin{array}{l}\text { Solicitação de } \\
\text { intervenção em ponto } \\
\text { de drogas } \\
\end{array}$ \\
\hline Conduta inadequada & Infração disciplinar & Infração disciplinar & Infração disciplinar & Infração disciplinar \\
\hline Negligência & Negligência & Negligência & Negligência & Negligência \\
\hline \multirow[t]{3}{*}{ Outros } & Outros & Outros & Outros & Outros \\
\hline & Elogio & Elogio & & \\
\hline & & $\begin{array}{l}\text { Comunicação de } \\
\text { crime }\end{array}$ & $\begin{array}{l}\text { Comunicação de } \\
\text { crime }\end{array}$ & $\begin{array}{l}\text { Comunicação de } \\
\text { crime }\end{array}$ \\
\hline
\end{tabular}




\begin{tabular}{|c|c|c|c|c|}
\hline 2001 & 2002 & 2003 & 2004 & 2005 \\
\hline \multicolumn{5}{|c|}{ Violência } \\
\hline Abuso de autoridade & Abuso de autoridade & Abuso de autoridade & Abuso de autoridade & Abuso de autoridade \\
\hline Espancamento/Tortura & Espancamento/Tortura & Espancamento/Tortura & Tortura & Tortura \\
\hline Ameaça & Ameaça & Ameaça & Ameaça & Ameaça \\
\hline $\begin{array}{l}\text { Homicídio cometido } \\
\text { por policial }\end{array}$ & $\begin{array}{l}\text { Homicídio cometido } \\
\text { por policial }\end{array}$ & $\begin{array}{l}\text { Homicídio cometido } \\
\text { por policial }\end{array}$ & Homicídio & Homicídio \\
\hline $\begin{array}{l}\text { Tentativa de } \\
\text { homicídio por policial }\end{array}$ & $\begin{array}{l}\text { Tentativa de } \\
\text { homicídio por policial }\end{array}$ & $\begin{array}{l}\text { Tentativa de homicídio } \\
\text { por policial }\end{array}$ & Tentativa de homicídio & Tentativa de homicídio \\
\hline Agressão & Agressão & Agressão & Agressão & Agressão \\
\hline \multirow[t]{11}{*}{ Maus tratos } & Maus tratos & Maus tratos & Maus tratos & Maus tratos \\
\hline & Lesão corporal grave & Lesão corporal grave & $\begin{array}{l}\text { Lesão corporal (fora do } \\
\text { exercício da polícia) }\end{array}$ & $\begin{array}{l}\text { Lesão corporal (fora do } \\
\text { exercício da polícia) }\end{array}$ \\
\hline & Invasão de domicílio & Invasão de domicílio & $\begin{array}{l}\text { Abuso (Invasão de } \\
\text { domicílio) }\end{array}$ & $\begin{array}{l}\text { Abuso (Invasão de } \\
\text { domicílio) }\end{array}$ \\
\hline & & & $\begin{array}{l}\text { Abuso de autoridade } \\
\text { (agressão) }\end{array}$ & $\begin{array}{l}\text { Abuso de autoridade } \\
\text { (agressão) }\end{array}$ \\
\hline & & & $\begin{array}{l}\text { Abuso } \\
\text { (constrangimento } \\
\text { ilegal) }\end{array}$ & $\begin{array}{l}\text { Abuso } \\
\text { (constrangimento } \\
\text { ilegal) }\end{array}$ \\
\hline & & & Abuso (prisão) & Abuso (prisão) \\
\hline & & & Abuso (outros) & Abuso (outros) \\
\hline & & & $\begin{array}{l}\text { Abordagem com } \\
\text { excesso }\end{array}$ & $\begin{array}{l}\text { Abordagem com } \\
\text { excesso }\end{array}$ \\
\hline & & & Discriminação & Discriminação \\
\hline & & & & Maus tratos a presos \\
\hline & & & & Assédio moral \\
\hline \multicolumn{5}{|c|}{ Corrupção } \\
\hline $\begin{array}{l}\text { Tráfico de drogas com } \\
\text { participação de } \\
\text { policial }\end{array}$ & $\begin{array}{l}\text { Tráfico de drogas com } \\
\text { participação de } \\
\text { policial }\end{array}$ & $\begin{array}{l}\text { Tráfico de drogas com } \\
\text { participação de policial }\end{array}$ & $\begin{array}{l}\text { Tráfico de drogas com } \\
\text { participação de policial }\end{array}$ & $\begin{array}{l}\text { Tráfico de drogas com } \\
\text { envolvimento de } \\
\text { policiais }\end{array}$ \\
\hline Concussão & Concussão & Concussão & Concussão & Concussão \\
\hline Prevaricação & Prevaricação & Prevaricação & Prevaricação & Prevaricação \\
\hline Corrupção & Corrupção & Corrupção & Corrupção passiva & Corrupção passiva \\
\hline Enriquecimento ilícito & Enriquecimento ilícito & Enriquecimento ilícito & Enriquecimento ilícito & Enriquecimento ilícito \\
\hline \multirow[t]{4}{*}{ Peculato } & \multirow[t]{4}{*}{ Peculato } & \multirow[t]{4}{*}{ Peculato } & Peculato - desvio & Peculato - desvio \\
\hline & & & Peculato - furto & Peculato - furto \\
\hline & & & \multirow[t]{2}{*}{ Peculato - apropriação } & Peculato - apropriação \\
\hline & & & & Peculato \\
\hline Estelionato & Estelionato & Estelionato & Peculato - estelionato & Peculato - estelionato \\
\hline Facilitação de fuga & Facilitação de fuga & Facilitação de fuga & Facilitação de fuga & $\begin{array}{l}\text { Promoção (facilitação } \\
\text { de fuga) }\end{array}$ \\
\hline \multirow[t]{5}{*}{$\begin{array}{l}\text { Roubo de carga com } \\
\text { participação de } \\
\text { policial }\end{array}$} & $\begin{array}{l}\text { Roubo de carga com } \\
\text { participação de } \\
\text { policial }\end{array}$ & $\begin{array}{l}\text { Roubo de carga com } \\
\text { participação de policial }\end{array}$ & $\begin{array}{l}\text { Roubo de carga com } \\
\text { participação de policial }\end{array}$ & $\begin{array}{l}\text { Roubo de carga com } \\
\text { participação de policial }\end{array}$ \\
\hline & $\begin{array}{l}\text { Crime contra o } \\
\text { consumidor }\end{array}$ & & & \\
\hline & Roubo/Furto & Roubo/Furto & Roubo/Furto & Roubo/Furto \\
\hline & & & Extorsão & Extorsão \\
\hline & & & & Falsidade ideológica \\
\hline \multicolumn{5}{|c|}{ Irregularidades administrativas } \\
\hline $\begin{array}{l}\text { Qualidade do } \\
\text { atendimento }\end{array}$ & $\begin{array}{l}\text { Qualidade do } \\
\text { atendimento }\end{array}$ & $\begin{array}{l}\text { Qualidade do } \\
\text { atendimento }\end{array}$ & $\begin{array}{l}\text { Má qualidade no } \\
\text { atendimento }\end{array}$ & $\begin{array}{l}\text { Má qualidade no } \\
\text { atendimento }\end{array}$ \\
\hline Falta de policiamento & Falta de policiamento & Falta de policiamento & Falta de policiamento & Falta de policiamento \\
\hline $\begin{array}{l}\text { Solicitação de } \\
\text { intervenção em ponto } \\
\text { de drogas }\end{array}$ & $\begin{array}{l}\text { Solicitação de } \\
\text { intervenção em ponto } \\
\text { de drogas }\end{array}$ & $\begin{array}{l}\text { Solicitação de } \\
\text { intervenção em ponto } \\
\text { de drogas }\end{array}$ & $\begin{array}{l}\text { Solicitação de } \\
\text { intervenção em ponto } \\
\text { de drogas }\end{array}$ & $\begin{array}{l}\text { Solicitação de } \\
\text { intervenção em ponto } \\
\text { de drogas }\end{array}$ \\
\hline
\end{tabular}




\begin{tabular}{|l|l|l|l|l|}
\hline Infração disciplinar & Infração disciplinar & Infração disciplinar & Infração disciplinar & Infração disciplinar \\
\hline Negligência & Negligência & Negligência & Negligência & Negligência \\
\hline Outros & Outros & Outros & Outros & Outros \\
\hline $\begin{array}{l}\text { Comunicação de } \\
\text { crime }\end{array}$ & $\begin{array}{l}\text { Comunicação de } \\
\text { crime }\end{array}$ & Comunicação de crime & Comunicação de crime & Comunicação de crime \\
\hline & & & $\begin{array}{l}\text { Solicitação de } \\
\text { policiamento }\end{array}$ & $\begin{array}{l}\text { Solicitação de } \\
\text { policiamento }\end{array}$ \\
\hline & & & $\begin{array}{l}\text { Reclamação contra } \\
\text { superior hierárquico }\end{array}$ \\
\hline & & & $\begin{array}{l}\text { Morosidade no } \\
\text { andamento da polícia } \\
\text { judiciária }\end{array}$ \\
\hline & & & $\begin{array}{l}\text { Falta de recursos } \\
\text { materiais }\end{array}$ \\
\hline & & & $\begin{array}{l}\text { Falta de recursos } \\
\text { humanos }\end{array}$ \\
\hline & & & $\begin{array}{l}\text { Favorecimento } \\
\text { indevido de } \\
\text { policiamento } \\
\text { preventivo }\end{array}$ \\
\hline & & & $\begin{array}{l}\text { Privilégio (benefício } \\
\text { indevido em escala) }\end{array}$ \\
\hline & & & Superlotação carcerária \\
\hline & & & $\begin{array}{l}\text { Ocultação de } \\
\text { identificação de viatura }\end{array}$ \\
\hline
\end{tabular}




\begin{abstract}
ANEXO 4
Pesquisa sobre a disponibilidade da informação do telefone da Ouvidoria da Polícia de São Paulo junto às delegacias de polícia da grande São Paulo
\end{abstract}

Os telefones corretos são 0800-177070 (é o mesmo desde a criação da ouvidoria, em 1995), 3291-6006, 3291-6024 e 3291-6032.

Pergunta: "Por favor, eu queria o telefone da ouvidoria?"

Data: última semana de julho e primeira semana de agosto de 2005.

Os números de telefone são os que constam no catálogo telefônico Listão OESP - A lista de São Paulo, Osasco, ABCD e região 2005, distribuído aos assinantes da Telefônica. (O número de telefone da ouvidoria da polícia não consta no catálogo telefônico). Alguns números de telefone estavam desatualizados e foi preciso consultar a internet ou o serviço de informações da Polícia Civil (197) para obter o número correto.

\begin{tabular}{|c|c|c|c|c|}
\hline \multicolumn{5}{|c|}{ DELEGACIAS DE DEFESA DA MULHER } \\
\hline Distrito & Telefone & manhã & tarde & noite \\
\hline $1^{\mathrm{a}}-$ Centro & $3241-3328$ & $\begin{array}{l}2 \mathrm{~min}, 181 \mathrm{e} \\
197\end{array}$ & & $\begin{array}{l}2 \min \\
3337-3712 \\
\text { (seccional) }\end{array}$ \\
\hline $2^{\mathrm{a}}$ - Vila Clementino & $5084-2579$ & $5 \operatorname{seg}, 197$ & & Atendeu um fax \\
\hline $3^{\mathrm{a}}$ - Jaguaré & $3768-4664$ & $5 \mathrm{seg}, 102$ e 197 & & Não atendeu \\
\hline $4^{\mathrm{a}}$ - Freguesia do Ó & $3976-2908$ & $5 \mathrm{seg}, 197$ & & Atendeu um fax \\
\hline $5^{\mathrm{a}}$ - Parque São Jorge & $293-3816$ & $15 \mathrm{seg}, 197$ & & Atendeu um fax \\
\hline $6^{\mathrm{a}}$ - Campo Grande & $5686-1895$ & $5 \mathrm{seg}, 197$ e 147 & & Atendeu um fax \\
\hline $7^{\mathrm{a}}$ - Vila Jacuí & $6154-1362$ & $\begin{array}{l}20 \text { seg, } 3227- \\
6344 \text { (Delegacia } \\
\text { Geral) }\end{array}$ & & Atendeu um fax \\
\hline $8^{\mathrm{a}}$ - São Matheus & $6742-1701$ & $5 \mathrm{seg}, 197$ & & Não atendeu \\
\hline $9^{a}-$ Pirituba & $3974-8890$ & $5 \mathrm{seg}, 197$ & & Não atendeu \\
\hline Carapicuíba & $4187-7183$ & $\begin{array}{l}30 \text { seg, 4184- } \\
2345 \text { (Seccional } \\
\text { de Carapicuíba) }\end{array}$ & & Não atendeu \\
\hline Cotia & $4616-9098$ & $\begin{array}{l}1 \mathrm{~min}, 0800- \\
156315 \text { (Disque }\end{array}$ & & Não atendeu \\
\hline
\end{tabular}




\begin{tabular}{|c|c|c|c|}
\hline & & $\begin{array}{l}\text { denúncia, } \mathrm{n}^{\circ} \\
\text { antigo) e } 3348- \\
2312 \text { (Gabinete } \\
\text { do Secretário) }\end{array}$ & \\
\hline Diadema & $4048-1904$ & $\begin{array}{l}1 \mathrm{~min}, 0800- \\
177070 \text { correto }\end{array}$ & Não atendeu \\
\hline Embu das Artes & $4781-1431$ & $\begin{array}{l}15 \text { seg, 4138- } \\
3316 \text { (Seccional } \\
\text { de Taboão da } \\
\text { Serra) }\end{array}$ & Não atendeu \\
\hline Osasco & $3682-4485$ & $1 \mathrm{~min}, 197$ & Não atendeu \\
\hline Santo André & $4438-4032$ & $\begin{array}{l}15 \mathrm{seg}, 181 \mathrm{e} \\
4438-1212 \text { ou } \\
4438-1414 \\
\text { (ambos da } \\
\text { Seccional) } \\
\end{array}$ & Não atendeu \\
\hline $\begin{array}{l}\text { São Bernardo do } \\
\text { Campo }\end{array}$ & $4368-2032$ & 20 seg, 102 & Não atendeu \\
\hline Taboão da Serra & $4138-3409$ & $\begin{array}{l}1 \mathrm{~min}, 4138- \\
3340 \\
\text { (Seccional) } \\
\end{array}$ & Não atendeu \\
\hline
\end{tabular}

Obs: no período da noite as ligações efetuadas entre 21:00 e 22:00 horas, no período da manhã as ligações foram efetuadas entre 11:00 e 12:00 horas.

Período da noite

No período da noite as ligações foram efetuadas entre 21:00 e 22:00 horas do dia 28/07/2005. O único telefone que atendeu foi o do $1^{\circ}$ Distrito - Centro. Uma mulher muito atenciosa foi procurar o telefone da ouvidoria, mas não o encontrou. Ela nos forneceu, então, ao cabo de dois minutos, o número da Seccional (3337-3712). Na Seccional foram fornecidos em 1 minuto dois telefones: $3823-5879$ como sendo o número da ouvidoria (o que está incorreto), e 3823-5802 como sendo o número de telefone do plantão do Gabinete do Secretário de Segurança Pública. Nenhum dos dois atenderam.

Período da manhã

No período da manhã, as ligações foram efetuadas entre 11:00 e 12:00 horas do dia $29 / 07 / 2005$. 
Ao ligar para o número 147, responde uma gravação. "Telefônica informa: este número de telefone não existe. Favor consultar o catálogo telefônico ou chamar o serviço de informações".

Na Delegacia de Carapicuíba, nos indicaram o número 4184-2345, da Seccional de Carapicuíba. Neste novo número, nos indicaram dois novos telefones 3242-1070 e 3242-0565. O primeiro não atendeu. No segundo, uma gravação da Telefônica indica que o número não existe.

Na Delegacia da Vila Jacuí, nos forneceram o número 3227-6344, da Delegacia Geral de Santa Cecília. Neste número conseguimos, em 1 minuto, o telefone correto da Ouvidoria da Polícia 0800-177070.

Na Delegacia de Cotia, nos forneceram em um minuto os números 0800-156315 (Disque denúncia, $\mathrm{n}^{\circ}$ antigo) e 3348-2312 (Gabinete do Secretário). No primeiro número, uma gravação indica o novo número do disque denúncia, 181. No 181, sugerem ligar para o 197. Ao ligar para o 3348-2312, que corresponde ao gabinete do secretário, nos indicaram o número 3291-6500, que também é do gabinete do secretário. Neste último número, nos forneceram corretamente o número da ouvidoria 0800177070.

Na Delegacia de Santo André, nos forneceram, em 15 segundos, o número 181 do Disque Denúncia e os números 4438-1212 e 4438-1414, ambos da Seccional. Na Seccional, após um minuto e meio de espera, conseguimos o número correto da Ouvidoria de Polícia 0800-177070.

\begin{tabular}{|l|c|l|l|l|}
\hline \multicolumn{5}{|c|}{ DELEGACIAS E DISTRITOS POLICIAIS } \\
\hline Distrito Policial & Telefone & manhã & tarde & noite \\
\hline $1^{\circ}$ Sé & $3341-3840$ & & & $\begin{array}{l}30 \mathrm{seg}, 147\left(\mathrm{n}^{\mathbf{o}}\right. \\
\text { antigo do 197) }\end{array}$ \\
\hline $2^{\circ}$ Bom Retiro & $221-6943$ & & $20 \mathrm{seg}, 147$ & \\
\hline $3^{\circ}$ Santa Ifigênia & $223-9839$ & & $1 \mathrm{~min}, 3311-3300$ & \\
\hline
\end{tabular}




\begin{tabular}{|c|c|c|c|c|}
\hline $4^{\circ}$ Consolação & $3256-4571$ & & $15 \mathrm{seg}, 197$ & \\
\hline $5^{\circ}$ Aclimação & $3208-0052$ & & $10 \mathrm{seg}, 197$ & \\
\hline $6^{\circ}$ Cambuci & $3208-4118$ & & $1 \mathrm{~min}, 3311-3300$ & \\
\hline $7^{\circ}$ Lapa & $3864-7445$ & & $5 \mathrm{seg}, 197$ & \\
\hline $8^{\circ}$ Belenzinho & $6291-9474$ & & & $5 \mathrm{seg}, 197$ \\
\hline $9^{\circ}$ Carandiru & $6909-9860$ & & $1 \mathrm{~min}, 197$ & \\
\hline $10^{\circ}$ Penha & $6192-6859$ & Não atendeu & $5 \mathrm{seg}, 197$ & Não atendeu \\
\hline $11^{\circ}$ Santo Amaro & $5548-8716$ & & $15 \mathrm{seg}, 197$ & Atendeu um fax \\
\hline $12^{\circ}$ Pari & $6292-3537$ & & & $\begin{array}{l}1 \text { min, pediu } \\
\text { para ligar em } 5 \\
\text { min pois ia } \\
\text { procurar no } \\
\text { computador, na } \\
\text { segunda ligação } \\
\text { foi fornecido o } \\
n^{0} \text { correto } 0800 \text { - } \\
177070\end{array}$ \\
\hline $13^{\circ}$ Casa Verde & $3966-1190$ & & & $5 \mathrm{seg}, 181$ \\
\hline $14^{\circ}$ Pinheiros & $3032-1100$ & & & $\begin{array}{l}20 \text { seg, } 197 \text { e } \\
3311-3300 \\
\text { (informações da } \\
\text { PC) }\end{array}$ \\
\hline $15^{\circ}$ Itaim Bibi & $3079-0400$ & & & $\begin{array}{l}15 \mathrm{seg}, 0800- \\
177070 \text { correto }\end{array}$ \\
\hline $16^{\circ}$ Vila Clementino & $5573-0363$ & & & $5 \mathrm{seg}, 102$ \\
\hline $17^{\circ}$ Ipiranga & $6161-2062$ & & & $\begin{array}{l}2 \text { min, 3231- } \\
5536 \\
\text { (corregedoria da } \\
\text { Polícia Civil) }\end{array}$ \\
\hline $18^{\circ}$ Alto da Mooca & $273-5751$ & & & $1 \mathrm{~min}, 197$ \\
\hline $19^{\circ}$ Vila Maria & $6954-2868$ & & & $5 \mathrm{seg}, 197$ \\
\hline $20^{\circ}$ Água Fria & $6203-8801$ & & $1 \mathrm{~min}, 197$ & \\
\hline $21^{\circ}$ Vila Matilde & $6651-7502$ & & $10 \mathrm{seg}, 147$ & \\
\hline $\begin{array}{l}22^{\circ} \text { São Miguel } \\
\text { Paulista }\end{array}$ & $6297-0639$ & & $1 \mathrm{~min}, 197$ & \\
\hline $23^{\circ}$ Perdizes & $3864-5265$ & & $15 \mathrm{seg}, 197$ & \\
\hline $\begin{array}{l}24^{\circ} \text { Ermelino } \\
\text { Matarazzo }\end{array}$ & $6546-5369$ & & $5 \mathrm{seg}, 197$ & \\
\hline $25^{\circ}$ Parelheiros & $5920-8959$ & & $\begin{array}{l}2 \min 30 \mathrm{seg}, 157 \\
\text { (não existe) }\end{array}$ & \\
\hline $26^{\circ}$ Sacomã & $6946-2719$ & & 30 seg, 197 & \\
\hline $27^{\circ}$ Campo Belo & $5543-2694$ & $\begin{array}{l}20 \text { seg, } 185 \\
\text { (não existe) }\end{array}$ & & \\
\hline $28^{\circ}$ Freguesia do Ó & $3976-5246$ & & $30 \mathrm{seg}, 197$ & \\
\hline $29^{\circ}$ Vila Diva & $6107-6100$ & $5 \mathrm{seg}, 197$ & $\begin{array}{l}15 \text { seg, 6213- } \\
8231 \text { (plantão) }\end{array}$ & \\
\hline $30^{\circ}$ Tatuapé & $295-0103$ & & $\begin{array}{l}30 \text { seg, 3311- } \\
3300\end{array}$ & \\
\hline $31^{\circ}$ Vila Carrão & 6194-3033 & & 45 seg, 197 & \\
\hline
\end{tabular}




\begin{tabular}{|c|c|c|c|c|}
\hline $32^{\circ}$ Itaquera & $6205-6015$ & & $45 \mathrm{seg}, 102$ & \\
\hline $33^{\circ}$ Pirituba & $3904-4057$ & & $5 \mathrm{seg}, 102$ & \\
\hline $34^{\circ}$ Vila Sônia & $3742-8886$ & & $\begin{array}{l}20 \text { seg, 3815- } \\
6433 \text { (Decap) }\end{array}$ & \\
\hline $35^{\circ}$ Jabaquara & $5011-1531$ & & $20 \mathrm{seg}, 197$ & \\
\hline $36^{\circ}$ Paraíso & $3884-4229$ & & $\begin{array}{l}1 \mathrm{~min}, 0800- \\
177070 \text { correto }\end{array}$ & \\
\hline $37^{\circ}$ Campo Limpo & $5841-5744$ & & $1 \mathrm{~min}, 181$ & \\
\hline $38^{\circ}$ Vila Amália & $6232-2181$ & & $30 \mathrm{seg}, 147$ & \\
\hline $39^{\circ}$ Vila Gustavo & $6989-6328$ & & $10 \mathrm{seg}, 197$ & \\
\hline $40^{\circ}$ Vila Maria & $3936-4929$ & & & 5 seg, 3311-3300 \\
\hline $41^{\circ}$ Vila Rica & $6724-5575$ & & $\begin{array}{l}15 \mathrm{seg}, 3311- \\
3300\end{array}$ & \\
\hline $42^{\circ}$ Parque São Lucas & $6211-4392$ & & & $15 \mathrm{seg}, 147$ \\
\hline $43^{\circ}$ Cidade Ademar & $5562-7924$ & & $5 \mathrm{seg}, 197$ & Não atendeu \\
\hline $44^{\circ}$ Guaianazes & $6557-9208$ & & & $10 \mathrm{seg}, 181$ \\
\hline $45^{\circ}$ Brasilândia & $3921-3653$ & & & $5 \mathrm{seg}, 197$ \\
\hline $46^{\circ}$ Perus & $3917-0727$ & & & $\begin{array}{l}30 \text { seg, 3311- } \\
3406 \text { (Gabin. } \\
\text { Oeste Cepol) }\end{array}$ \\
\hline $47^{\circ}$ Capão Redondo & $5821-2805$ & & & $5 \mathrm{seg}, 102$ \\
\hline $48^{\circ}$ Cidade Dutra & $5666-0723$ & & & $\begin{array}{l}5 \mathrm{seg}, 147\left(\mathrm{n}^{\circ}\right. \\
\text { antigo do } 197)\end{array}$ \\
\hline $49^{\circ}$ São Mateus & $6919-4977$ & & $30 \mathrm{seg}, 147$ & Não atendeu \\
\hline $50^{\circ}$ Itaim Paulista & $6963-2633$ & & $\begin{array}{l}30 \text { seg, 3311- } \\
3662 \text { (Cepol) }\end{array}$ & \\
\hline $51^{\circ}$ Butantã & $3727-1211$ & & $45 \mathrm{seg}, 147$ & \\
\hline $52^{\circ}$ Parque São Jorge & $6193-3632$ & & $5 \mathrm{seg}, 197$ & \\
\hline $53^{\circ}$ Parque do Carmo & $6521-7325$ & & & $1 \mathrm{~min}, 190(\mathrm{PM})$ \\
\hline $54^{\circ}$ Cidade Tiradentes & $6282-8756$ & & $10 \mathrm{seg}, 147$ & \\
\hline $55^{\circ}$ Parque São Rafael & $6919-8627$ & & $\begin{array}{l}15 \mathrm{seg}, 6919- \\
5582 \text { (cartório) }\end{array}$ & \\
\hline $56^{\circ}$ Vila Alpina & 6341-1637 & & $30 \mathrm{seg}, 197$ & \\
\hline $57^{\circ}$ Parque da Mooca & $6965-6644$ & $\begin{array}{l}30 \mathrm{seg}, 102 \mathrm{e} \\
147\end{array}$ & Atendeu um fax & \\
\hline $58^{\circ}$ Vila Formosa & $6673-2169$ & & $30 \mathrm{seg}, 197$ e 190 & \\
\hline $59^{\circ}$ Jardim dos Ipês & 6581-3929 & & $30 \mathrm{seg}, 197$ & \\
\hline $62^{\circ}$ Jardim Popular & $6546-4961$ & & $5 \mathrm{seg}, 197$ & \\
\hline $63^{\circ}$ Vila Jacuí & $6151-9463$ & & $\begin{array}{l}30 \text { seg, 3311- } \\
3862 \text { (Cepol) }\end{array}$ & \\
\hline $\begin{array}{l}64^{\circ} \text { Cidade AE } \\
\text { Carvalho }\end{array}$ & $6280-3444$ & & $\begin{array}{l}1 \mathrm{~min}, 3311-6268 \\
(\mathrm{Cepol})\end{array}$ & \\
\hline $65^{\circ}$ Arthur Alvim & $6741-3891$ & & 30 seg, 197 & \\
\hline $\begin{array}{l}66^{\circ} \text { Vale do } \\
\text { Aricanduva }\end{array}$ & $6742-5297$ & & $30 \mathrm{seg}, 197$ & \\
\hline $67^{\circ}$ Jardim Robru & $6135-1813$ & & $5 \mathrm{seg}, 197$ & \\
\hline $68^{\circ}$ Jardim Lajeado & $6552-5199$ & & $\begin{array}{l}1 \mathrm{~min} 30 \mathrm{seg} \\
0800-177070 \text { e } \\
3291-6027\end{array}$ & \\
\hline
\end{tabular}




\begin{tabular}{|c|c|c|c|c|}
\hline & & & corretos & \\
\hline $69^{\circ}$ Teotônio Vilela & $6704-5085$ & & $10 \mathrm{seg}, 102$ & \\
\hline $70^{\circ}$ Sapopemba & $6702-0454$ & & $5 \mathrm{seg}, 147$ & \\
\hline $72^{\circ}$ Vila Penteado & $3851-4488$ & & $30 \mathrm{seg}, 197$ & \\
\hline $73^{\circ}$ Jaçanã & $6241-6974$ & & $5 \mathrm{seg}, 197$ & \\
\hline $74^{\circ}$ Parada de Taipas & $3971-4824$ & & $5 \mathrm{seg}, 197$ & \\
\hline $75^{\circ}$ Jardim Arpoador & $3782-0879$ & & $\begin{array}{l}1 \mathrm{~min} \text { e } 45 \mathrm{seg}, \\
197\end{array}$ & \\
\hline $77^{\circ}$ Santa Cecília & $221-5860$ & $\begin{array}{l}1 \mathrm{~min}, 0800- \\
178989 \\
\text { (Procuradoria) }\end{array}$ & & \\
\hline $78^{\circ}$ Jardins & $3086-0945$ & & $15 \mathrm{seg}, 197$ & \\
\hline $80^{\circ}$ Vila Joaniza & $5621-7339$ & & & $\begin{array}{l}15 \mathrm{seg}, 147\left(\mathrm{n}^{\circ}\right. \\
\text { antigo do } 197)\end{array}$ \\
\hline $81^{\circ}$ Belém & $6693-9496$ & & & $\begin{array}{l}30 \mathrm{seg}, 197 \mathrm{e} \\
102\end{array}$ \\
\hline $83^{\circ}$ Parque Bristol & $6331-9581$ & & & $1 \mathrm{~min}, 190$ e 102 \\
\hline $85^{\circ}$ Jardim Mirna & $5526-9938$ & $5 \mathrm{seg}, 102$ & & Não atendeu \\
\hline $\begin{array}{l}87^{\circ} \text { Vila Pereira } \\
\text { Barreto }\end{array}$ & $3974-8603$ & & $\begin{array}{l}1 \mathrm{~min} 30 \mathrm{seg}, \\
0800-177070 \\
\text { correto }\end{array}$ & Não atendeu \\
\hline $89^{\circ}$ Portal do Morumbi & $3743-8439$ & 5 seg, 147 & & \\
\hline $\begin{array}{l}90^{\circ} \text { Parque Novo } \\
\text { Mundo }\end{array}$ & $6201-2957$ & & & $\begin{array}{l}15 \mathrm{seg}, 197 \mathrm{e} \\
102\end{array}$ \\
\hline $91^{\circ}$ Vila Leopoldina & $3831-4916$ & & & $15 \mathrm{seg}, 197$ \\
\hline $\begin{array}{l}92^{\circ} \text { Parque Santo } \\
\text { Antônio }\end{array}$ & $5511-9615$ & & & $1 \mathrm{~min}, 197$ \\
\hline $93^{\circ}$ Jaguaré & $3768-3717$ & & & $\begin{array}{l}2 \mathrm{~min}, 3231- \\
5536 \\
\text { (corregedoria da } \\
\text { Polícia Civil) } \\
\end{array}$ \\
\hline $95^{\circ}$ Cohab Heliópolis & $6161-7700$ & & $\begin{array}{l}1 \mathrm{~min}, 5506-7444 \\
\text { (seccional) }\end{array}$ & Não atendeu \\
\hline $96^{\circ}$ Monções/Brooklin & $5505-5819$ & $15 \mathrm{seg}, 197$ & & Não atendeu \\
\hline $97^{\circ}$ Americanópolis & $5588-4841$ & & & $10 \mathrm{seg}, 197$ \\
\hline $98^{\circ}$ Jardim Miriam & $5621-7279$ & & $15 \mathrm{seg}, 147$ & Não atendeu \\
\hline $99^{\circ}$ Campo Grande & $5521-6653$ & & & $30 \mathrm{seg}, 197$ \\
\hline $100^{\circ}$ Jardim Herculano & $5831-2380$ & & & $\begin{array}{l}15 \mathrm{seg}, 190 \\
(\mathrm{PM}) \\
197(\mathrm{PC}) \\
\end{array}$ \\
\hline $\begin{array}{l}101^{\circ} \text { Jardim das } \\
\text { Imbuias }\end{array}$ & $5928-5952$ & & & $\begin{array}{l}15 \text { seg, } 102 \\
\text { (Auxílio à lista) }\end{array}$ \\
\hline $\begin{array}{l}102^{\circ} \text { Capela do } \\
\text { Socorro }\end{array}$ & $5686-2051$ & & $\begin{array}{l}5 \text { seg, 3889-3000 } \\
\text { (Cepol) }\end{array}$ & Atendeu um fax \\
\hline $103^{\circ}$ Cohab II-Itaquera & $6521-6549$ & & & $\begin{array}{l}2 \text { min, } 181 \\
\text { (disque } \\
\text { denúncia) }\end{array}$ \\
\hline
\end{tabular}




\begin{tabular}{|c|c|c|c|c|}
\hline $1^{a}$ Seccional - Centro & $3331-2200$ & $\begin{array}{l}30 \text { seg, 3291- } \\
6024 \text { (correto) } \\
\text { e } 3112-2432 \\
\text { (não existe) }\end{array}$ & & \\
\hline $2^{\mathrm{a}}$ Seccional - Sul & $5506-7444$ & & $10 \mathrm{seg}, 197$ & \\
\hline $3^{\text {a }}$ Seccional - Oeste & $3032-0872$ & & 5 seg, 3311-3300 & \\
\hline $4^{\mathrm{a}}$ Seccional - Norte & $3858-0200$ & & $\begin{array}{l}30 \text { seg, 3291- } \\
6500 \text { (Gabinete } \\
\text { do secretário) }\end{array}$ & \\
\hline $5^{\text {a }}$ Seccional - Leste & $6291-0091$ & & $\begin{array}{l}1 \text { min e } 15 \text { seg, } \\
3106-0047 \text { (não } \\
\text { existe) e } 3106- \\
4369 \text { (residencial) }\end{array}$ & \\
\hline $\begin{array}{l}6^{\mathrm{a}} \text { Seccional - Santo } \\
\text { Amaro }\end{array}$ & $5521-6729$ & & $\begin{array}{l}30 \mathrm{seg}, 3291- \\
6107 \text { (não existe) }\end{array}$ & \\
\hline $\begin{array}{l}7^{\circ} \text { Seccional - Itaquera } \\
\text { Cohab II }\end{array}$ & 6521-1494 & & $\begin{array}{l}1 \mathrm{~min}, 0800- \\
177070 \text { correto }\end{array}$ & \\
\hline $\begin{array}{l}8^{\text {a }} \text { Seccional - São } \\
\text { Mateus }\end{array}$ & 6704-0011 & & & $5 \mathrm{seg}, 3311-3300$ \\
\hline $\begin{array}{l}\text { Carapicuíba } 1^{\circ} \text { Vila } \\
\text { Caldas }\end{array}$ & $4164-3132$ & & $\begin{array}{l}15 \mathrm{seg}, 4184- \\
2345 \text { (seccional) }\end{array}$ & \\
\hline Cajamar $1^{\circ}$ Polvilho & $4448-1821$ & & $\begin{array}{l}1 \mathrm{~min} 15 \mathrm{seg}, \\
0800-177070 \\
(\text { correto) }\end{array}$ & \\
\hline Cajamar/Jordanésia & $4447-4779$ & & $\begin{array}{l}40 \text { seg, 3311- } \\
3300\end{array}$ & \\
\hline $\begin{array}{l}\text { Carapicuíba } 2^{\circ} \text { Cidade } \\
\text { Ariston }\end{array}$ & $4181-6564$ & & $\begin{array}{l}20 \mathrm{seg}, 4184- \\
2345 \text { (seccional) }\end{array}$ & \\
\hline $\begin{array}{l}\text { Carapicuíba } 3^{\circ} \text { Vila } \\
\text { Marcondes }\end{array}$ & $4187-4500$ & & $\begin{array}{l}2 \mathrm{~min}, 4184-2345 \\
\text { (seccional) }\end{array}$ & \\
\hline $\begin{array}{l}\text { Carapicuíba - } \\
\text { Seccional }\end{array}$ & $4184-2345$ & & $\begin{array}{l}1 \mathrm{~min}, 3242-1070 \\
\text { e } 3242-0565 \text { (não } \\
\text { existe) }\end{array}$ & \\
\hline Cotia & $4703-2034$ & & & $\begin{array}{l}15 \text { seg, 0800- } \\
156315 \text { (disque } \\
\text { denúncia) ( } \mathrm{n}^{\circ} \\
\text { antigo) }\end{array}$ \\
\hline $\begin{array}{l}\text { Cotia } 1^{\circ} \text { Cocaia do } \\
\text { Auto }\end{array}$ & $4611-0020$ & & $\begin{array}{l}30 \mathrm{seg}, 0800- \\
631563\end{array}$ & Não atendeu \\
\hline Cotia $2^{\circ}$ Granja Viana & $4702-2454$ & & $\begin{array}{l}1 \text { min e } 30 \mathrm{seg}, \\
4184-2345 \\
\text { (seccional) }\end{array}$ & \\
\hline DECAP & $3815-6433$ & & & $\begin{array}{l}1 \text { min, } 197 \\
\text { (Polícia Civil } \\
\text { informações) }\end{array}$ \\
\hline $\begin{array}{l}\text { Delegacia de Proteção } \\
\text { ao idoso }\end{array}$ & $3237-0666$ & & $5 \mathrm{seg}, 102$ & Não atendeu \\
\hline $\begin{array}{l}\text { Diadema } 1^{\circ} \text { Vila } \\
\text { Conceição }\end{array}$ & $4043-3366$ & & $1 \mathrm{~min}, 3311-3300$ & Não atendeu \\
\hline
\end{tabular}




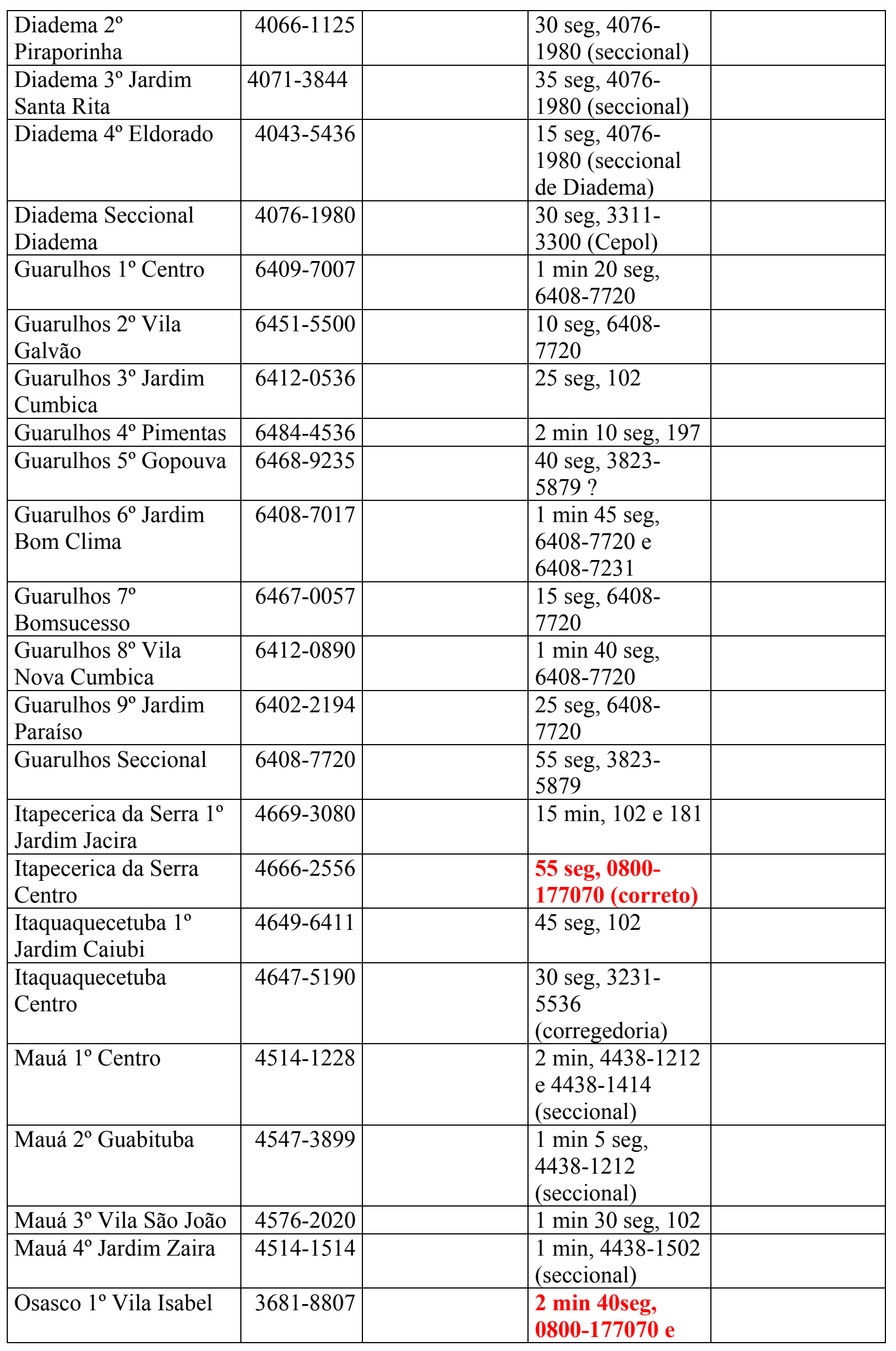




\begin{tabular}{|c|c|c|c|c|}
\hline & & & $\begin{array}{l}3291-6006 \\
\text { (correto) }\end{array}$ & \\
\hline Osasco $2^{\circ}$ Jardim Novo & $3609-3024$ & & $\begin{array}{l}2 \text { min, } 0800- \\
7711175 \\
\text { (ouvidoria da } \\
\text { prefeitura de } \\
\text { Osasco) }\end{array}$ & \\
\hline $\begin{array}{l}\text { Osasco } 3^{\circ} \text { Jardim } \\
\text { Rochdalle }\end{array}$ & $3687-5451$ & & $\begin{array}{l}2 \mathrm{~min}, 3652-9000 \\
\text { (Prefeitura de } \\
\text { Osasco) }\end{array}$ & \\
\hline $\begin{array}{l}\text { Osasco } 4^{\circ} \text { Jardim } \\
\text { Piratininga }\end{array}$ & $3686-2218$ & & $\begin{array}{l}30 \text { seg, 3683- } \\
1045 \text { (seccional } \\
\text { da central) }\end{array}$ & \\
\hline Osasco $5^{\circ}$ Centro & $3682-4480$ & & $15 \mathrm{seg}, 102$ & \\
\hline $\begin{array}{l}\text { Osasco } 6^{\circ} \text { Vila } \\
\text { Campesina }\end{array}$ & $3682-6133$ & & $1 \mathrm{~min}, 197$ & \\
\hline Osasco $7^{\circ}$ Vila Menck & $3601-5000$ & & $1 \mathrm{~min}, 3311-3300$ & \\
\hline Osasco $8^{\circ}$ Vila Iolanda & $3605-8299$ & & $3 \mathrm{~min}, 3682-0522$ & Não atendeu \\
\hline $\begin{array}{l}\text { Osasco } 9^{\circ} \text { Presidente } \\
\text { Altino }\end{array}$ & $3681-8355$ & $\begin{array}{l}3681-6946 \\
\text { (seccional) }\end{array}$ & & Atendeu um fax \\
\hline $\begin{array}{l}\text { Osasco } 10^{\circ} \text { Helena } \\
\text { Maria }\end{array}$ & $3687-6239$ & & $15 \mathrm{seg}, 147$ & Não atendeu \\
\hline Osasco Entorpecentes & $3683-5020$ & & $15 \mathrm{seg}, 147$ & Não atendeu \\
\hline $\begin{array}{l}\text { Osasco Seccional } \\
\text { Osasco }\end{array}$ & $3681-6946$ & & $\begin{array}{l}2 \text { min, 3112-2432 } \\
\text { (não existe) e } \\
3823-5879 \\
\text { (errado) }\end{array}$ & \\
\hline Santo André $1^{\circ}$ Centro & $4438-1179$ & & $\begin{array}{l}15 \text { seg, } 4438- \\
1502 \text { (seccional) }\end{array}$ & \\
\hline $\begin{array}{l}\text { Santo André } 2^{\circ} \\
\text { Camilópolis }\end{array}$ & $4461-5659$ & & $\begin{array}{l}3 \text { min e } 15 \mathrm{seg} \\
4438-1502 \\
\text { (seccional) }\end{array}$ & \\
\hline $\begin{array}{l}\text { Santo André } 3^{\circ} \text { Vila } \\
\text { Pires }\end{array}$ & $4972-3127$ & $\begin{array}{l}1 \mathrm{~min}, 4438- \\
1502 \\
\text { (seccional) }\end{array}$ & & \\
\hline $\begin{array}{l}\text { Santo André } 4^{\circ} \text { Santo } \\
\text { André }\end{array}$ & 4991-4538 & & $\begin{array}{l}15 \text { seg, 4438- } \\
1502 \text { (seccional } \\
\text { de Santo André) }\end{array}$ & \\
\hline $\begin{array}{l}\text { Santo André } 5^{\circ} \text { Parque } \\
\text { Novo Oratório }\end{array}$ & $4479-2949$ & & $\begin{array}{l}3 \text { min, } 4438-1502 \\
\text { (seccional) }\end{array}$ & \\
\hline $\begin{array}{l}\text { Santo André } 6^{\circ} \text { Jardim } \\
\text { do Estácio }\end{array}$ & $4451-2011$ & & $\begin{array}{l}3 \mathrm{~min}, 0800- \\
177070 \text { correto }\end{array}$ & \\
\hline $\begin{array}{l}\text { Santo André Seccional } \\
\text { Vila Bastos }\end{array}$ & $4438-1212$ & $\begin{array}{l}1 \text { min e } 30 \mathrm{seg}, \\
0800-177070 \\
\text { correto }\end{array}$ & & \\
\hline $\begin{array}{l}\text { São Bernardo do } \\
\text { Campo } 1^{\circ}\end{array}$ & $4125-1133$ & & & $\begin{array}{l}30 \text { seg, 3242- } \\
0442 \text { (não } \\
\text { existe) }\end{array}$ \\
\hline São Bernardo do & $4368-8852$ & & $30 \mathrm{seg}, 0800-$ & \\
\hline
\end{tabular}




\begin{tabular}{|c|c|c|c|}
\hline $\begin{array}{l}\text { Campo } 2^{\circ} \text { Rudge } \\
\text { Ramos }\end{array}$ & & 177070 correto & \\
\hline $\begin{array}{l}\text { São Bernardo do } \\
\text { Campo } 3^{\circ} \text { Assunção }\end{array}$ & $4351-1200$ & $\begin{array}{l}2 \mathrm{~min}, 0800- \\
177070 \text { correto }\end{array}$ & \\
\hline $\begin{array}{l}\text { São Bernardo do } \\
\text { Campo } 4^{\circ} \text { Riacho } \\
\text { Grande }\end{array}$ & $4354-0472$ & $\begin{array}{l}45 \mathrm{seg}, 4125- \\
1377 \text { (seccional) }\end{array}$ & \\
\hline $\begin{array}{l}\text { São Bernardo do } \\
\text { Campo } 5^{\circ} \text { Paulicéia }\end{array}$ & $4173-1241$ & $\begin{array}{l}15 \mathrm{seg}, 4125- \\
1377 \text { (seccional) }\end{array}$ & \\
\hline $\begin{array}{l}\text { São Bernardo do } \\
\text { Campo } 6^{\circ} \text { Baeta Neves }\end{array}$ & $4125-0694$ & $\begin{array}{l}5 \mathrm{seg}, 4125-1377 \\
\text { (seccional) }\end{array}$ & \\
\hline $\begin{array}{l}\text { São Bernardo do } \\
\text { Campo } 7^{\circ}\end{array}$ & $4124-6991$ & $\begin{array}{l}15 \mathrm{seg}, 4125- \\
1377 \text { (seccional) }\end{array}$ & \\
\hline $\begin{array}{l}\text { São Bernardo do } \\
\text { Campo Seccional - } \\
\text { Vila Euclides }\end{array}$ & $4330-1212$ & $\begin{array}{l}1 \mathrm{~min} 30 \mathrm{seg} \\
3311-3300\end{array}$ & \\
\hline $\begin{array}{l}\text { São Caetano do Sul } 1^{\circ} \\
\text { Centro }\end{array}$ & $4221-1212$ & & $45 \mathrm{seg}, 181$ \\
\hline $\begin{array}{l}\text { São Caetano do Sul } 2^{\circ} \\
\text { Vila Santa Maria }\end{array}$ & $4220-3098$ & $\begin{array}{l}45 \mathrm{seg}, 0800- \\
156315\left(\mathrm{n}^{\circ} \text { antigo }\right. \\
\text { do disque- } \\
\text { denúncia) }\end{array}$ & \\
\hline $\begin{array}{l}\text { São Caetano do Sul } 3^{\circ} \\
\text { Vila Nova Gerty }\end{array}$ & $4238-1044$ & $\begin{array}{l}15 \text { seg, 4232- } \\
7373 \text { (Prefeitura } \\
\text { de São Caetano) } \\
\end{array}$ & \\
\hline Taboão da Serra & $4701-2603$ & & $\begin{array}{l}1 \mathrm{~min}, 0800- \\
177070 \text { correto }\end{array}$ \\
\hline
\end{tabular}

Noite: dia 28/07/2005 entre 22:00 e 1:30 horas

Nota: Os seguintes distritos policiais $\left(60^{\circ}\right.$ DP Vila Esperança, $61^{\circ}$ DP Cangaíba, $71^{\circ}$ DP Santana, $76^{\circ}$ DP Parque Dom Pedro II, $79^{\circ}$ DP Bela Vista, $82^{\circ}$ DP Canindé, $84^{\circ}$ DP Vila Madalena, $86^{\circ}$ DP Barra Funda, $88^{\circ}$ DP Cidade Jardim, $94^{\circ}$ DP Moema) foram criados, mas ainda não estão instalados.

No DECAP nos forneceram em um minuto o telefone 197 (Polícia Civil Informações). Ao ligar para o 197, um atendente perguntou qual dos telefones da ouvidoria estávamos buscando. Respondemos que queríamos o telefone para fazer uma reclamação. Conseguimos, então, em um minuto, os dois telefones corretos da ouvidoria 0800-177070 e 3291-6006.

Quando nos forneceram o telefone antigo do disque denúncia (0800-156315), uma gravação indicou o telefone novo (181). No 181, nos indicaram em um minuto o telefone 197 para informações. 
No serviço de auxílio à lista (102), mantido pela companhia telefônica, conseguimos o número correto da ouvidoria da polícia 0800-177070.

No serviço de informações da Polícia Civil, obtivemos, em 30 segundos, os telefones corretos 0800-177070, 3291-6006 e 3291-6042.

Em vários casos, ao invés do número 197, referente à polícia civil, é fornecido o número 3311-3662 ou 3311-3300 da Cepol (Centro de Comunicação da Polícia Civil).

Algumas reações:

- Ichi... Ouvidoria, não tenho aqui...

- (para alguém na sala) Tem ouvidoria da polícia civil? (impropério) Vê se acha aí o telefone... Vou mandar ele ligar no $197 \ldots$

- ouvidoria do que? Do município ou do estado?

- Ou-vi-do-ri-a...? um minutinho...

- Ouvidoria? Eu não tenho aqui em mãos...

- Como? Ouvidoria do que? Da Polícia Civil ou da Polícia Militar?

- O que? Não temos aqui não, grande. Liga na central que lá eles te informam, é 197.

- Da ouvidoria? Agora você me pegou amigo... Vou ver se eu tenho aqui... Assistência do Judiciário eu tenho, mas lá não tem plantão à noite... E eu tenho minhas dúvidas se na ouvidoria tem plantão. Eu sei que na corregedoria tem. Você já tentou no 190? Essa eu vou ficar te devendo amigo... É alguma coisa com o meu distrito aqui? Quem sabe eu posso resolver? Ah, não? Então é diferente... Acho que o mais seguro é procurar pelo auxílio à lista, 102. É que raramente alguém procura o telefone da ouvidoria aqui. 
- Como? Telefone de onde? Ou-vi-do-ria? Quem ta falando? Vou ver se eu acho aqui... (para alguém na sala) Ô fulano, vê aí o telefone da corregedoria... não é nada não, é só alguém aqui pedindo o telefone...

- Não entendi? Ouvidoria? Vou ver se eu tenho aqui, um minutinho...

- Ouvidoria? Não sei, rapaz, tem que ligar no 147.

- Ouvidoria? Pois não... Como é que é, você quer o telefone da ouvidoria?!! Nós não temos aqui não...

- Ouvidoria? Você fala de onde? De São Paulo? ... (para alguém na sala) Ô fulano, canta aí o telefone da ouvidoria de São Paulo...

- Ouvidoria? Da Polícia Militar ou da Polícia Civil? (Tem diferença? Achei que fosse uma só?) Tem diferença, sim. Tem que saber qual das duas ouvidorias você está procurando...

- Ihh... Agora você me pegou... Vou ver se eu tenho aqui...

- De quem?... Desculpe-me, senhor, mas aqui não tem ninguém com esse nome. Aqui é uma delegacia de polícia...

- Da ou-vi-do-ri-a?... Agora você me pegou! Da Corregedoria eu sei de cor, mas da ouvidoria não... Faça-me uma gentileza, ligue por favor no 197

- Ou-vi-do-ri-a?... Hum, que pergunta difícil, heim!... Eu não tenho para te informar... Você já tentou no 102? Boa Sorte!...

- Ouvidoria? É para fazer alguma denúncia? (Sim, gostaria de fazer uma reclamação) Você pode estar fazendo aqui comigo... (Mas eu prefiro fazer na ouvidoria) Talvez se você fizesse aqui comigo o trâmite seria mais rápido... (pausa) Em todo caso eu vou procurar o telefone da ouvidoria... Aqui está, 0800-156315 (trata-se do telefone antigo do disque-denúncia). 
- Ai, eu vou ficar te devendo meu amor... eu não tenho aqui... faz o seguinte, dá uma ligadinha no 197 e eles te dão o telefone da ouvidoria e da corregedoria ... é alguma coisa em que eu possa ajudar?

- Olha, eu não tenho nada aqui. Como ninguém nunca ligou pedindo esse telefone, eu não tenho ele aqui...

- Ouvidoria? Boa pergunta, meu amigo... Esse número não consta da nossa relação. Você é a primeira pessoa que procura essa informação por aqui... Você pode ligar daqui a uns dez minutos, vou tentar localizar essa informação para você.

- Ouvidoria? Quem está falando? É um cidadão comum?... Então liga no 190.

- Ouvidoria? Um momento, por favor... Ouvidoria do que, da civil ou da militar? (Eu estou procurando o número da Ouvidoria da Polícia) Então faz o seguinte, cavalheiro, ligue para o ${ }^{\circ} \mathrm{XXXXXXX}$ que é o da nossa chefia...

Tabulação dos resultados:

\begin{tabular}{|l|c|c|c|}
\hline Delegacias & $\mathbf{N}^{\mathbf{0}}$ total & $\mathbf{N}^{\mathbf{0}}$ de acertos & Porcentagem \\
\hline Distritos Policiais (SP) & 93 & 5 & $5,4 \%$ \\
\hline Delegacias da mulher & 17 & 1 & $5,9 \%$ \\
\hline Seccionais (São Paulo) & 8 & 2 & $25 \%$ \\
\hline Grande São Paulo e outras & 59 & 7 & $11,9 \%$ \\
\hline Seccionais (Grande São Paulo) & 6 & 1 & $16,7 \%$ \\
\hline Total & 183 & 16 & $8,7 \%$ \\
\hline
\end{tabular}




\section{ANEXO 5}

Pesquisa sobre a disponibilidade da informação do telefone da Ouvidoria da Polícia de São Paulo junto aos batalhões da polícia militar da grande São Paulo

Um batalhão de Polícia Militar é constituído por companhias em número aproximado de quatro. O batalhão é comandado por um Tenente Coronel Policial Militar e as companhias por um Capitão Policial Militar. As companhias têm efetivo, viaturas, equipamentos e sede própria. Elas estão mais presentes no dia a dia do cidadão, no patrulhamento, em eventos e Conselhos Comunitários, por exemplo. São elas que cumprem todas as missões de policiamento emanadas dos comandos da corporação. Ao ligar para o telefone 190 o fato relatado é imediatamente repassado para os policiais em viaturas de uma companhia.

Telefones corretos: 0800-177070, 3291-6027, 3291-6029 e 3291-6032.

\begin{tabular}{|c|c|c|c|c|c|}
\hline Bairro & Batalhão & CIA & Endereço & Telefone & $\begin{array}{l}\text { Resultado da } \\
\text { solicitação do } \\
\text { número da } \\
\text { Ouvidoria }\end{array}$ \\
\hline Jardim São Luis & $01^{\circ} \mathrm{BPM} / \mathrm{M}$ & Sede & $\begin{array}{l}\text { Rua Geraldo Fraga de } \\
\text { Oliveira, } 270\end{array}$ & \begin{tabular}{|l|}
$5851-1582$ \\
$5852-5294 / 6184$ \\
$/ 6171 / 5681$
\end{tabular} & $\begin{array}{l}30 \mathrm{seg}, 230-0033\left(\mathrm{n}^{\mathrm{o}}\right. \\
\text { inexistente) }\end{array}$ \\
\hline $\begin{array}{l}\text { Parque Santo } \\
\text { Antônio }\end{array}$ & $01^{\circ} \mathrm{BPM} / \mathrm{M}$ & $\begin{array}{l}1^{\mathrm{a}} \mathrm{Cia} \\
2^{\mathrm{a}} \mathrm{Cia}\end{array}$ & \begin{tabular}{|l|} 
Rua Maria Benedita \\
Rodrigues, 300
\end{tabular} & $819-7716$ & \\
\hline Capão Redondo & $01^{\circ} \mathrm{BPM} / \mathrm{M}$ & $3^{\mathrm{a}} \mathrm{Cia}$ & $\begin{array}{l}\text { Rua Pastor Gerônimo } \\
\text { Graneiro Garcia, } 11\end{array}$ & $5660-6390$ & $15 \mathrm{seg}, 5668-7666$ \\
\hline Jardim Angela & $01^{\circ} \mathrm{BPM} / \mathrm{M}$ & $4^{\mathrm{a}} \mathrm{Cia}$ & & $5666-3768$ & $2 \min 10 \operatorname{seg}, 181$ \\
\hline Vila Esperança & $02^{\circ} \mathrm{BPM} / \mathrm{M}$ & Sede & $\begin{array}{l}\text { Av. Amador Bueno } \\
\text { da Veiga, } 2774\end{array}$ & $\begin{array}{l}6958-5732 \\
6957-3944 \\
6957-4566 \\
\end{array}$ & $30 \mathrm{seg}, 6957-4618$ \\
\hline Burgo Paulista & $02^{\circ} \mathrm{BPM} / \mathrm{M}$ & $1^{\mathrm{a}} \mathrm{Cia}$ & \begin{tabular}{|l|} 
Rua Antonio \\
Fortunato, 931 \\
\end{tabular} & $6280-9549$ & $25 \mathrm{seg}, 190$ \\
\hline Vila Jacuí & $02^{\circ} \mathrm{BPM} / \mathrm{M}$ & $2^{\mathrm{a}} \mathrm{Cia}$ & Av. São Miguel, 7901 & \begin{tabular}{|l|}
$6956-6477$ \\
$6956-4463$ \\
$6956-0138$ \\
\end{tabular} & $40 \mathrm{seg}, 190$ \\
\hline Vila Constância & $02^{\circ} \mathrm{BPM} / \mathrm{M}$ & $3^{\mathrm{a}} \mathrm{Cia}$ & Rua Dr Saul de & $6943-7700$ & $25 \mathrm{seg}, 102$ \\
\hline
\end{tabular}




\begin{tabular}{|c|c|c|c|c|c|}
\hline & & & Camargo Neves, s/n ${ }^{\circ}$ & & \\
\hline $\begin{array}{l}\text { Parque } \\
\text { Boturussu }\end{array}$ & $02^{\circ} \mathrm{BPM} / \mathrm{M}$ & $4^{\mathrm{a}} \mathrm{Cia}$ & $\begin{array}{l}\text { Rua Cerro de Mateus } \\
\text { Simões, } 187\end{array}$ & $\begin{array}{l}6546-3800 \\
6546-3747 \\
\end{array}$ & $1 \mathrm{~min}, 190$ \\
\hline Limoeiro & $02^{\circ} \mathrm{BPM} / \mathrm{M}$ & Cia FT & Av. Imperador, 3705 & $6280-6223$ & $1 \mathrm{~min} 15 \mathrm{seg}, 190$ \\
\hline Água Funda & $03^{\circ} \mathrm{BPM} / \mathrm{M}$ & $\begin{array}{c}\text { Sede } \\
\text { Cia FT } \\
\end{array}$ & $\begin{array}{l}\text { Av. Miguel Stéfano, } \\
3900\end{array}$ & $\begin{array}{l}5073-1666 / 9896 \\
/ 5157 \\
\end{array}$ & $\begin{array}{l}35 \text { seg, 3315-0188 } \\
\text { (batalhão da ROTA) }\end{array}$ \\
\hline Jabaquara & $03^{\circ} \mathrm{BPM} / \mathrm{M}$ & $1^{\mathrm{a}} \mathrm{Cia}$ & $\begin{array}{l}\text { Av. Eng. George } \\
\text { Corbisier, } 322- \\
\text { Fundos } \\
\end{array}$ & $5012-0378$ & $5 \mathrm{seg}, 102$ \\
\hline Ipiranga & $03^{\circ} \mathrm{BPM} / \mathrm{M}$ & $2^{\mathrm{a}} \mathrm{Cia}$ & \begin{tabular}{|l} 
Rua Dom Luis \\
Lasagna, 534
\end{tabular} & $6914-7235$ & $40 \mathrm{seg}, 181$ \\
\hline Sacomã & $03^{\circ} \mathrm{BPM} / \mathrm{M}$ & $3^{\mathrm{a}} \mathrm{Cia}$ & $\begin{array}{l}\text { Rua Padre Arlindo } \\
\text { Vieira, } 50\end{array}$ & $6946-9366$ & 35 seg, 5073-1666 \\
\hline Água Funda & $03^{\circ} \mathrm{BPM} / \mathrm{M}$ & $4^{\mathrm{a}} \mathrm{Cia}$ & $\begin{array}{l}\text { Av. Miguel Stefano, } \\
3900\end{array}$ & $5073-6307$ & $\begin{array}{l}1 \text { min } 30 \text { seg, 3322- } \\
0190\end{array}$ \\
\hline Ipiranga & $03^{\circ} \mathrm{BPM} / \mathrm{M}$ & $5^{\mathrm{a}} \mathrm{Cia}$ & \begin{tabular}{|l|} 
Av. Comandante \\
Taylor, 1180
\end{tabular} & $272-9550$ & $50 \mathrm{seg}, 190$ \\
\hline $\begin{array}{l}\text { Jardim Santa } \\
\text { Cruz }\end{array}$ & $03^{\circ} \mathrm{BPM} / \mathrm{M}$ & $6^{\mathrm{a}} \mathrm{Cia}$ & $\begin{array}{l}\text { Rua Prof. Silas } \\
\text { Matos, } 535\end{array}$ & $6336-2130$ & $15 \mathrm{seg}, 190$ \\
\hline City Lapa & $04^{\circ} \mathrm{BPM} / \mathrm{M}$ & Sede & $\begin{array}{l}\text { Rua Tomé de Souza, } \\
1420\end{array}$ & $\begin{array}{l}3834-6121 / 6730 \\
3834-2411\end{array}$ & $\begin{array}{l}4 \mathrm{~min}, 190,0800- \\
555190(\mathrm{PM}) \mathrm{e} \\
\mathbf{0 8 0 0 - 1 7 7 0 7 0} \\
\text { (correto) }\end{array}$ \\
\hline Vila Romana & $04^{\circ} \mathrm{BPM} / \mathrm{M}$ & $1^{\mathrm{a}} \mathrm{Cia}$ & Rua Vespasiano, 807 & $3864-0280$ & $5 \mathrm{seg}, 190$ \\
\hline Vila Leopoldina & $04^{\circ} \mathrm{BPM} / \mathrm{M}$ & $2^{\mathrm{a}} \mathrm{Cia}$ & $\begin{array}{l}\text { Av. Gastão Vidigal, } \\
1946\end{array}$ & $3836-8996$ & $\begin{array}{l}3 \text { min } 50 \text { seg, } 3832- \\
4834 \text { e } 3834-6121\end{array}$ \\
\hline Vila Mangalot & $04^{\circ} \mathrm{BPM} / \mathrm{M}$ & $3^{\mathrm{a}} \mathrm{Cia}$ & \begin{tabular}{|l|} 
Rua Joaquim de \\
Oliveira Freitas, 1170 \\
\end{tabular} & $3904-4554$ & $\begin{array}{l}1 \mathrm{~min} 50 \mathrm{seg}, 0800- \\
156315\end{array}$ \\
\hline \multirow[t]{2}{*}{ Perus } & $04^{\circ} \mathrm{BPM} / \mathrm{M}$ & $4^{\mathrm{a}} \mathrm{Cia}$ & $\begin{array}{l}\text { Rua Comendador } \\
\text { Fiorelli Peciccaco, } \\
320\end{array}$ & $3915-6471$ & 50 seg, 190 \\
\hline & $04^{\circ} \mathrm{BPM} / \mathrm{M}$ & $5^{\mathrm{a}} \mathrm{Cia}$ & & $3992-6347$ & $25 \mathrm{seg}, 190$ \\
\hline $\begin{array}{l}\text { Jardim Cidade } \\
\text { Pirituba }\end{array}$ & $04^{\circ} \mathrm{BPM} / \mathrm{M}$ & Cia FT & \begin{tabular}{|l|} 
Rua João de \\
Carvalhais, 280 \\
\end{tabular} & $3836-7856$ & $\begin{array}{l}2 \text { min } 5 \text { seg, } 3322- \\
0190 \text { (corregedoria) }\end{array}$ \\
\hline Vila Maria & $05^{\circ} \mathrm{BPM} / \mathrm{M}$ & Sede & Rua Amambaí, 9 & $\begin{array}{l}6967-9806 / 9800 \\
6967-9881\end{array}$ & 30 seg, 3106-0770 \\
\hline Carandirú & $05^{\circ} \mathrm{BPM} / \mathrm{M}$ & $1^{\mathrm{a}} \mathrm{Cia}$ & $\begin{array}{l}\text { Rua dos Camares, 94- } \\
\text { A }\end{array}$ & $6901-9837$ & $\begin{array}{l}2 \text { min, } 3823-5715, \\
3823-5735 \text { e } \mathbf{0 8 0 0}- \\
\mathbf{1 7 7 0 7 0} \text { (correto) } \\
\end{array}$ \\
\hline Vila Maria & $05^{\circ} \mathrm{BPM} / \mathrm{M}$ & $2^{\mathrm{a}} \mathrm{Cia}$ & Rua Amambaí, 1181 & $6954-2876$ & $10 \min , 190$ \\
\hline Vila Gustavo & $05^{\circ} \mathrm{BPM} / \mathrm{M}$ & $3^{\mathrm{a}} \mathrm{Cia}$ & $\begin{array}{l}\text { Rua da Esperança, } \\
797\end{array}$ & $6989-3742$ & $35 \mathrm{seg}, 190$ \\
\hline Jaçanã & $05^{\circ} \mathrm{BPM} / \mathrm{M}$ & $4^{\mathrm{a}} \mathrm{Cia}$ & $\begin{array}{l}\text { Rua Michel Ouchana, } \\
194\end{array}$ & $6246-4246$ & $\begin{array}{l}1 \text { min, } 0800-177070 \\
\text { (correto) }\end{array}$ \\
\hline $\begin{array}{l}\text { Parque Novo } \\
\text { Mundo }\end{array}$ & $05^{\circ} \mathrm{BPM} / \mathrm{M}$ & $5^{\mathrm{a}} \mathrm{Cia}$ & Rua José Serafim, 62 & $6636-1483$ & $\begin{array}{l}30 \text { seg, 3327-7000 } \\
(\text { Copom) }\end{array}$ \\
\hline $\begin{array}{l}\text { Parque Novo } \\
\text { Mundo }\end{array}$ & $05^{\circ} \mathrm{BPM} / \mathrm{M}$ & $6^{\mathrm{a}} \mathrm{Cia}$ & Junto à sede da $3^{\mathrm{a}} \mathrm{Cia}$ & 6981-0025 & 15 seg, 181 \\
\hline São Bernardo do & $06^{\circ} \mathrm{BPM} / \mathrm{M}$ & Sede & Rua Ligure, 180 & $4123-2360$ & $20 \mathrm{seg}, 3832-5879$ \\
\hline
\end{tabular}




\begin{tabular}{|c|c|c|c|c|c|}
\hline $\begin{array}{l}\text { Campo/Jardim } \\
\text { do Mar }\end{array}$ & & & & $4125-1010$ & \\
\hline $\begin{array}{l}\text { São Bernardo do } \\
\text { Campo/Nova } \\
\text { Petrópolis }\end{array}$ & $06^{\circ} \mathrm{BPM} / \mathrm{M}$ & $1^{\mathrm{a}} \mathrm{Cia}$ & $\begin{array}{l}\text { Rua Dom Paulo } \\
\text { Mariano, } 245\end{array}$ & $4123-7073$ & 50 seg, 3322-0190 \\
\hline $\begin{array}{l}\text { São Bernardo do } \\
\text { Campo/Taboão }\end{array}$ & $06^{\circ} \mathrm{BPM} / \mathrm{M}$ & $2^{\mathrm{a}} \mathrm{Cia}$ & Av. do Taboão, 3000 & $\begin{array}{l}4363-3006 \\
4363-3692 \\
\end{array}$ & $50 \mathrm{seg}, 102$ \\
\hline $\begin{array}{l}\text { São Caetano do } \\
\text { Sul/Santa Paula }\end{array}$ & $06^{\circ} \mathrm{BPM} / \mathrm{M}$ & $3^{\mathrm{a}} \mathrm{Cia}$ & Av. Goiás, 2000 & $4221-1010$ & $\begin{array}{l}2 \text { min } 5 \text { seg, } 4232- \\
9024 \text { e } 0800-19080\end{array}$ \\
\hline $\begin{array}{l}\text { São Bernardo do } \\
\text { Campo/Baeta } \\
\text { Neves }\end{array}$ & $06^{\circ} \mathrm{BPM} / \mathrm{M}$ & Cia FT & $\begin{array}{l}\text { Rua Giacinto } \\
\text { Tognato, } 305\end{array}$ & $4337-7473$ & $30 \mathrm{seg}, 190$ \\
\hline Higienópolis & $07^{\circ} \mathrm{BPM} / \mathrm{M}$ & Sede & Av. Angélica, 1647 & $\begin{array}{l}3663-0311 / 6386 \\
3661-8527 / 8348 \\
\end{array}$ & $30 \mathrm{seg}, 102$ \\
\hline Centro & $07^{\circ} \mathrm{BPM} / \mathrm{M}$ & $1^{\mathrm{a}} \mathrm{Cia}$ & Rua do Carmo, 38 & $3106-9610$ & $15 \mathrm{seg}, 190$ \\
\hline Centro & $07^{\circ} \mathrm{BPM} / \mathrm{M}$ & $2^{\mathrm{a}} \mathrm{Cia}$ & Rua Santo Amaro, 46 & $3101-5831$ & $5 \mathrm{seg}, 190$ \\
\hline Consolação & $07^{\circ} \mathrm{BPM} / \mathrm{M}$ & $3^{\mathrm{a}} \mathrm{Cia}$ & $\begin{array}{l}\text { Rua da Consolação, } \\
705 \text { A }\end{array}$ & $3256-6515$ & $\begin{array}{l}1 \text { min } 30 \text { seg, } 0800- \\
177070 \text { (correto) }\end{array}$ \\
\hline Jardim Paulista & $07^{\circ} \mathrm{BPM} / \mathrm{M}$ & $4^{\mathrm{a}} \mathrm{Cia}$ & $\begin{array}{l}\text { Rua Maestro Elias } \\
\text { Lobo, } 127\end{array}$ & $\begin{array}{l}3887-8796^{*} \\
\left(1^{\mathrm{a}} \mathrm{Cia} \text { do } 7^{\mathrm{o}}\right) \\
3885-7027^{\circ} \\
\end{array}$ & $5 \mathrm{seg}, 102$ \\
\hline Tatuapé & $08^{\circ} \mathrm{BPM} / \mathrm{M}$ & Sede & Rua Vilela, 307 & \begin{tabular}{|l}
$6197-7948 *$ \\
$6517-2324 / 4108$ \\
$295-6517 / 4108$ \\
$294-5929$ \\
$6192-5377$ \\
\end{tabular} & $\begin{array}{l}30 \text { seg, 3291-6027 } \\
\text { (correto) }\end{array}$ \\
\hline Tatuapé & $08^{\circ} \mathrm{BPM} / \mathrm{M}$ & $1^{\mathrm{a}} \mathrm{Cia}$ & $\begin{array}{l}\text { Rua Antônio } \\
\text { Camardo, } 69\end{array}$ & $294-3046$ & $15 \mathrm{seg}, 190$ \\
\hline Vila Carrão & $08^{\circ} \mathrm{BPM} / \mathrm{M}$ & $2^{\mathrm{a}} \mathrm{Cia}$ & $\begin{array}{l}\text { Rua Conselheiro } \\
\text { Carrão, } 2582\end{array}$ & $295-9562$ & $\begin{array}{l}1 \mathrm{~min} 15 \mathrm{seg}, 0800- \\
177070 \text { (correto) }\end{array}$ \\
\hline Penha & $08^{\circ} \mathrm{BPM} / \mathrm{M}$ & $3^{\mathrm{a}} \mathrm{Cia}$ & $\begin{array}{l}\text { Av. Airton Pretini, } \\
69-A\end{array}$ & $295-9973$ & $30 \mathrm{seg}, 190$ \\
\hline Belenzinho & $08^{\circ} \mathrm{BPM} / \mathrm{M}$ & $4^{\mathrm{a}} \mathrm{Cia}$ & $\begin{array}{l}\text { Largo São José do } \\
\text { Belém, s/n }{ }^{\mathbf{o}}\end{array}$ & $\begin{array}{c}\text { 6291-8479 } \\
\text { (base } \\
\text { comunitária) } \\
\text { 6096-7594 este } \\
\end{array}$ & $\begin{array}{l}5 \mathrm{seg}, 190 \\
30 \text { seg, 0800-177070 } \\
\text { (correto) }\end{array}$ \\
\hline Vila Mathilde & $08^{\circ} \mathrm{BPM} / \mathrm{M}$ & $5^{\mathrm{a}} \mathrm{Cia}$ & $\begin{array}{l}\text { Rua Dr. Pelágio } \\
\text { Marques, } 177\end{array}$ & $\begin{array}{l}6651-4315 \\
(6651-5318) \\
(6651-8979) \\
\end{array}$ & $45 \mathrm{seg}, 0800-156315$ \\
\hline Vila Zilda & $08^{\circ} \mathrm{BPM} / \mathrm{M}$ & $6^{\mathrm{a}} \mathrm{Cia}$ & Rua Vilela, 307 & $295-9782$ & \begin{tabular}{|l|}
5 seg, $0800-177070$ \\
(correto)
\end{tabular} \\
\hline $\begin{array}{l}\text { Jardim São } \\
\text { Paulo }\end{array}$ & $09^{\circ} \mathrm{BPM} / \mathrm{M}$ & Sede & $\begin{array}{l}\text { Av. Nova Cantareira, } \\
842\end{array}$ & $\begin{array}{l}(6976- \\
1729 / 1702 \\
6976-1266 \\
6973-3871\end{array}$ & $\begin{array}{l}35 \text { seg, } 0800-177070 \\
\text { (correto) }\end{array}$ \\
\hline Casa Verde & $09^{\circ} \mathrm{BPM} / \mathrm{M}$ & $1^{\mathrm{a}} \mathrm{Cia}$ & Av. Casa Verde, 677 & $3966-1086$ & $\begin{array}{l}1 \text { min } 5 \mathrm{seg}, 0800- \\
177707\end{array}$ \\
\hline Água Fria & $09^{\circ} \mathrm{BPM} / \mathrm{M}$ & $2^{\mathrm{a}} \mathrm{Cia}$ & Rua São Zeferino, 34 & 6991-8332 & $35 \mathrm{seg}, 3327-7000$ \\
\hline Horto Florestal & $09^{\circ} \mathrm{BPM} / \mathrm{M}$ & $3^{\mathrm{a}} \mathrm{Cia}$ & Rua Pedra Bonita, & $6232-9501$ & $55 \mathrm{seg}, 0800-555190$ \\
\hline
\end{tabular}




\begin{tabular}{|c|c|c|c|c|c|}
\hline & & & $\mathrm{s} / \mathrm{n}^{\mathrm{o}}$ & & $(\mathrm{PM})$ e 181 \\
\hline Vila Amália & $09^{\circ} \mathrm{BPM} / \mathrm{M}$ & $4^{\mathrm{a}} \mathrm{Cia}$ & $\begin{array}{l}\text { Av. Parada Pinto, } \\
2387\end{array}$ & $\begin{array}{l}6233-3595 \\
6232-9502\end{array}$ & $\begin{array}{l}1 \text { min, 3322-0190, } \\
3322-0183,6221- \\
0300 \text { (não existe), } \\
6221-0700 \text { (não } \\
\text { existe) }\end{array}$ \\
\hline Tucuruvi & $09^{\circ} \mathrm{BPM} / \mathrm{M}$ & Cia FT & $\begin{array}{l}\text { Av. Nova Cantareira, } \\
607\end{array}$ & $6979-1825$ & $25 \mathrm{seg}, 6976-1266$ \\
\hline $\begin{array}{l}\text { Santo André/ } \\
\text { Campestre }\end{array}$ & $10^{\circ} \mathrm{BPM} / \mathrm{M}$ & $\begin{array}{l}\text { Sede } \\
\text { Cia FT }\end{array}$ & Al. São Caetano, 903 & \begin{tabular}{|l|}
$4421-4422 / 9293$ \\
$3949 / 9888$
\end{tabular} & $4 \mathrm{~min} 10 \mathrm{seg}, 190$ \\
\hline $\begin{array}{l}\text { Santo André/ } \\
\text { Camilópolis }\end{array}$ & $10^{\circ} \mathrm{BPM} / \mathrm{M}$ & $1^{\mathrm{a}} \mathrm{Cia}$ & Rua Alemanha, 12 & $4461-1626$ & $35 \mathrm{seg}, 190$ \\
\hline $\begin{array}{l}\text { Santo } \\
\text { André/Utinga }\end{array}$ & $10^{\circ} \mathrm{BPM} / \mathrm{M}$ & $2^{\mathrm{a}} \mathrm{Cia}$ & Av. Utinga, 288 & $4997-3976$ & $15 \mathrm{seg}, 190$ \\
\hline Liberdade & $11^{\circ} \mathrm{BPM} / \mathrm{M}$ & Sede & $\begin{array}{l}\text { Rua Prof. Antonio } \\
\text { Prudente, } 48\end{array}$ & \begin{tabular}{|l|}
$3207-2688 / 2750$ \\
$3341-7191$ \\
$3208-0941$
\end{tabular} & $\begin{array}{l}30 \mathrm{seg}, 3327-7000 \text { e } \\
3327-7626\end{array}$ \\
\hline Bela Vista & $11^{\circ} \mathrm{BPM} / \mathrm{M}$ & $1^{\mathrm{a}} \mathrm{Cia}$ & Rua da Abolição, 349 & \begin{tabular}{|l|}
$3106-8436$ \\
$3104-0598$ \\
\end{tabular} & $\begin{array}{l}1 \min 25 \mathrm{seg}, 181 \mathrm{e} \\
190\end{array}$ \\
\hline Glicério & $11^{\circ} \mathrm{BPM} / \mathrm{M}$ & $2^{\mathrm{a}} \mathrm{Cia}$ & $\begin{array}{l}\text { Rua Otto de Alencar, } \\
230\end{array}$ & \begin{tabular}{|l|}
$3209-3749$ \\
$3209-7224$ \\
\end{tabular} & $20 \mathrm{seg}, 102$ \\
\hline Belém & $11^{\circ} \mathrm{BPM} / \mathrm{M}$ & $3^{\mathrm{a}} \mathrm{Cia}$ & Rua Sapucaia, 206 & \begin{tabular}{|l|}
$6618-1311$ \\
$6694-0901$ \\
\end{tabular} & $\begin{array}{l}45 \text { seg, 0800-707777 } \\
\text { e } 190\end{array}$ \\
\hline Praça da Sé & $11^{\circ} \mathrm{BPM} / \mathrm{M}$ & $4^{\mathrm{a}} \mathrm{Cia}$ & Rua do Carmo, s/n ${ }^{\circ}$ & $3106-9610 / 2102$ & $\begin{array}{l}1 \mathrm{~min} 20 \text { seg, 3322- } \\
0221 \text { (corregedoria) }\end{array}$ \\
\hline Liberdade & $11^{\circ} \mathrm{BPM} / \mathrm{M}$ & Cia FT & $\begin{array}{l}\text { Rua Prof. Antonio } \\
\text { Prudente, } 48\end{array}$ & $3341-7181$ & $15 \mathrm{seg}, 190$ \\
\hline Aeroporto & $12^{\circ} \mathrm{BPM} / \mathrm{M}$ & Sede & Rua Rafael Iorio, 160 & \begin{tabular}{|l|}
$5093-4174$ este \\
$5044-0833 / 5416$ \\
$5141-3712$ \\
\end{tabular} & $\begin{array}{l}25 \text { seg, } 3322-0190 \\
\text { (corregedoria) }\end{array}$ \\
\hline Campo Belo & $12^{\circ} \mathrm{BPM} / \mathrm{M}$ & $1^{\mathrm{a}} \mathrm{Cia}$ & $\begin{array}{l}\text { Rua República do } \\
\text { Iraque, } 1119\end{array}$ & $5041-3907$ & $\begin{array}{l}20 \text { seg, 0800-177070 } \\
\text { (correto) }\end{array}$ \\
\hline Vila Mariana & $12^{\circ} \mathrm{BPM} / \mathrm{M}$ & $2^{\mathrm{a}} \mathrm{Cia}$ & $\begin{array}{l}\text { Rua Sena Madureira, } \\
980\end{array}$ & $5579-3786$ & $1 \mathrm{~min}, 102$ \\
\hline Vila Clementino & $12^{\circ} \mathrm{BPM} / \mathrm{M}$ & $3^{\mathrm{a}} \mathrm{Cia}$ & $\begin{array}{l}\text { Av. Onze de Junho, } \\
89\end{array}$ & $5573-7786$ & $35 \mathrm{seg}, 0800-156315$ \\
\hline Nova Conceição & $12^{\circ} \mathrm{BPM} / \mathrm{M}$ & $4^{\mathrm{a}} \mathrm{Cia}$ & $\begin{array}{l}\text { Av. IV Centenário, } \\
1450\end{array}$ & $3845-5956$ & $55 \mathrm{seg}, 190$ \\
\hline Campos Elíseos & $13^{\circ} \mathrm{BPM} / \mathrm{M}$ & Sede & Av. Rio Branco, 1289 & \begin{tabular}{|l|}
$222-2833 / 1147$ \\
$222-2084 / 2282$ \\
\end{tabular} & $\begin{array}{l}1 \mathrm{~min}, 0800-177070 \\
\text { (correto) }\end{array}$ \\
\hline Campos Elíseos & $13^{\circ} \mathrm{BPM} / \mathrm{M}$ & $1^{\mathrm{a}} \mathrm{Cia}$ & Av. Rio Branco, 1289 & $222-2282$ & $\begin{array}{l}2 \text { min } 40 \text { seg, } 0800- \\
177070 \text { (correto) }\end{array}$ \\
\hline Santa Cecília & $13^{\circ} \mathrm{BPM} / \mathrm{M}$ & $2^{\mathrm{a}} \mathrm{Cia}$ & $\begin{array}{l}\text { Rua Dr. Gabriel dos } \\
\text { Santos, } 81\end{array}$ & \begin{tabular}{|l}
$3826-9411$ \\
$3826-9094$ \\
\end{tabular} & $\begin{array}{l}1 \mathrm{~min} 15 \mathrm{seg}, 181 \mathrm{e} \\
190\end{array}$ \\
\hline Pari & $13^{\circ} \mathrm{BPM} / \mathrm{M}$ & $3^{\mathrm{a}} \mathrm{Cia}$ & Rua Rio Bonito, 950 & \begin{tabular}{|l|}
$6694-3782$ \\
$6695-0977$ \\
\end{tabular} & $3 \mathrm{~min} 10 \mathrm{seg}, 102$ \\
\hline $\begin{array}{l}\text { Osasco/Jardim } \\
\text { Flores }\end{array}$ & $14^{\circ} \mathrm{BPM} / \mathrm{M}$ & Sede & $\begin{array}{l}\text { Av. Diogo Antônio } \\
\text { Feijó, } 511\end{array}$ & $\begin{array}{l}3681-7106 / 7107 \\
/ 7760\end{array}$ & $\mid \begin{array}{l}30 \mathrm{seg}, 3223-5879 \\
\text { (não existe) e } \mathbf{0 8 0 0 -} \\
\mathbf{1 7 7 0 7 0} \text { (correto) }\end{array}$ \\
\hline
\end{tabular}




\begin{tabular}{|c|c|c|c|c|c|}
\hline $\begin{array}{l}\text { Osasco/Jardim } \\
\text { Santo Antonio }\end{array}$ & $14^{\circ} \mathrm{BPM} / \mathrm{M}$ & $1^{\mathrm{a}} \mathrm{Cia}$ & $\begin{array}{l}\text { Av. João de Andrade, } \\
800\end{array}$ & $3609-1535$ & $30 \mathrm{seg}, 190$ \\
\hline Osasco/Centro & $14^{\circ} \mathrm{BPM} / \mathrm{M}$ & $2^{\mathrm{a}} \mathrm{Cia}$ & Av. João Batista, 955 & $3682-6299$ & $15 \mathrm{seg}, 158$ \\
\hline Osasco/Centro & $14^{\circ} \mathrm{BPM} / \mathrm{M}$ & $3^{\mathrm{a}} \mathrm{Cia}$ & $\begin{array}{l}\text { Av. Marechal } \\
\text { Rondon, } 330\end{array}$ & $3681-6166 / 3050$ & $\begin{array}{l}15 \mathrm{seg}, 3652-9000 \\
\text { (Prefeitura de } \\
\text { Osasco) }\end{array}$ \\
\hline $\begin{array}{l}\text { Guarulhos/Vila } \\
\text { Tijuco }\end{array}$ & $15^{\circ} \mathrm{BPM} / \mathrm{M}$ & Sede & $\begin{array}{l}\text { Rua Humberto de } \\
\text { Campos, } 715\end{array}$ & \begin{tabular}{|l|}
$6463-$ \\
$5504 / 5505 /$ \\
5506 e $6463-$ \\
5555 telefonista \\
\end{tabular} & $\begin{array}{l}1 \mathrm{~min} 20 \mathrm{seg}, 3327- \\
7000\end{array}$ \\
\hline Guarulhos & $15^{\circ} \mathrm{BPM} / \mathrm{M}$ & $1^{\mathrm{a}} \mathrm{Cia}$ & & $6424-0666$ & $\begin{array}{l}1 \mathrm{~min} 15 \mathrm{seg}, 0800- \\
156315\end{array}$ \\
\hline Guarulhos & $15^{\circ} \mathrm{BPM} / \mathrm{M}$ & $2^{\mathrm{a}} \mathrm{Cia}$ & & $6451-6239$ & $40 \mathrm{seg}, 102$ \\
\hline Guarulhos & $15^{\circ} \mathrm{BPM} / \mathrm{M}$ & $3^{\mathrm{a}} \mathrm{Cia}$ & & \begin{tabular}{|l|}
$6404-1679$ \\
$6407-7866$ \\
\end{tabular} & $15 \mathrm{seg}, 102$ \\
\hline Guarulhos & $15^{\circ} \mathrm{BPM} / \mathrm{M}$ & $4^{\mathrm{a}} \mathrm{Cia}$ & & $6461-1800$ & 10 seg, 190 \\
\hline Guarulhos & $15^{\circ} \mathrm{BPM} / \mathrm{M}$ & Cia FT & & $6463-5535$ & $30 \mathrm{seg}, 190$ \\
\hline Rio Pequeno & $16^{\circ} \mathrm{BPM} / \mathrm{M}$ & Sede & $\begin{array}{l}\text { Av. Corifeu de } \\
\text { Azevedo Marques, } \\
4082\end{array}$ & $\begin{array}{l}3769-2002 / 2004 \\
3769-2047\end{array}$ & $\begin{array}{l}40 \text { seg, } 3291-6027 \\
\text { (correto) }\end{array}$ \\
\hline Campo Limpo & $16^{\circ} \mathrm{BPM} / \mathrm{M}$ & $1^{\mathrm{a}} \mathrm{Cia}$ & Rua Jacaratinga, 201 & \begin{tabular}{|l|}
$5842-3803$ \\
$5841-2755$ \\
\end{tabular} & $\begin{array}{l}2 \text { min, 3322-0190 } \\
\text { (Corregedoria) }\end{array}$ \\
\hline Vila Sônia & $16^{\circ} \mathrm{BPM} / \mathrm{M}$ & $2^{\mathrm{a}} \mathrm{Cia}$ & $\begin{array}{l}\text { Av. Prof. Francisco } \\
\text { Morato, } 2971\end{array}$ & \begin{tabular}{|l|}
$3771-0299$ \\
$3422-6918$ \\
$3772-5503$ \\
\end{tabular} & $35 \mathrm{seg}, 3769-2000$ \\
\hline Butantã & $16^{\circ} \mathrm{BPM} / \mathrm{M}$ & $3^{\mathrm{a}} \mathrm{Cia}$ & Rua Barroso Neto, 60 & \begin{tabular}{|l|}
$3726-4716$ \\
$3726-7963$ \\
\end{tabular} & $1 \mathrm{~min}, 190$ \\
\hline Parque Ipê & $16^{\circ} \mathrm{BPM} / \mathrm{M}$ & $4^{\mathrm{a}} \mathrm{Cia}$ & Av. Vila Olímpica, 21 & \begin{tabular}{|l|}
$3784-5018$ \\
$3781-2041$ \\
\end{tabular} & $1 \mathrm{~min} 5 \mathrm{seg}, 190$ \\
\hline $\begin{array}{l}\text { Parque } \\
\text { Continental }\end{array}$ & $16^{\circ} \mathrm{BPM} / \mathrm{M}$ & $5^{\mathrm{a}} \mathrm{Cia}$ & $\begin{array}{l}\text { Av. Dr. Francisco de } \\
\text { Paula Vicente de } \\
\text { Azevedo, } 777\end{array}$ & $\begin{array}{l}3766-0176 \\
3768-7738\end{array}$ & $35 \mathrm{seg}, 190$ \\
\hline Vila Sônia & $16^{\circ} \mathrm{BPM} / \mathrm{M}$ & $6^{\mathrm{a}} \mathrm{Cia}$ & $\begin{array}{l}\text { Av. Prof. Francisco } \\
\text { Morato, } 2971\end{array}$ & \begin{tabular}{|l|}
$3742-6918$ \\
$3746-5512 / 5559$ \\
\end{tabular} & $1 \mathrm{~min} 40 \mathrm{seg}, 190$ \\
\hline Rio Pequeno & $16^{\circ} \mathrm{BPM} / \mathrm{M}$ & Cia FT & $\begin{array}{l}\text { Av. Corifeu de } \\
\text { Azevedo Marques, } \\
4082 \\
\end{array}$ & $\begin{array}{l}3768-2048 / 7738 \\
3772-0343\end{array}$ & $\begin{array}{l}15 \text { seg, } 102 \text { e } 190 \\
\text { base comunitária } \\
\text { morumbi }\end{array}$ \\
\hline $\begin{array}{l}\text { Mogi das } \\
\text { Cruzes/Centro } \\
\end{array}$ & $17^{\circ} \mathrm{BPM} / \mathrm{M}$ & Sede & $\begin{array}{l}\text { Rua Coronel Souza } \\
\text { Franco, } 1010\end{array}$ & $4799-7000 / 1036$ & $35 \mathrm{seg}, 3823-5879$ \\
\hline Mogi das Cruzes & $17^{\circ} \mathrm{BPM} / \mathrm{M}$ & $1^{\mathrm{a}} \mathrm{Cia}$ & & $4727-7699$ & $50 \mathrm{seg}, 4799-7000$ \\
\hline Mogi das Cruzes & $17^{\circ} \mathrm{BPM} / \mathrm{M}$ & $2^{\mathrm{a}} \mathrm{Cia}$ & & $4794-9777$ & $\begin{array}{l}1 \mathrm{~min} 10 \mathrm{seg}, 190 \mathrm{e} \\
4799-1011\end{array}$ \\
\hline Mogi das Cruzes & $17^{\circ} \mathrm{BPM} / \mathrm{M}$ & $3^{\mathrm{a}} \mathrm{Cia}$ & & $4693-2459$ & (correto) \\
\hline Freguesia do Ó & $18^{\circ} \mathrm{BPM} / \mathrm{M}$ & Sede & $\begin{array}{l}\text { Rua Chico de Paula, } \\
224\end{array}$ & \begin{tabular}{|l|}
$3931-9944 / 9190$ \\
$/ 7913 / 8081 / 814$ \\
$53935-2963$ \\
\end{tabular} & $\begin{array}{l}1 \mathrm{~min} 35 \mathrm{seg}, 3291- \\
6108 \text { (não existe) }\end{array}$ \\
\hline Freguesia do Ó & $18^{\circ} \mathrm{BPM} / \mathrm{M}$ & $1^{\mathrm{a}} \mathrm{Cia}$ & Av. Itaberaba, 731 & $\begin{array}{l}3976-0233 \\
3999-0307\end{array}$ & $15 \mathrm{seg}, 190$ \\
\hline
\end{tabular}




\begin{tabular}{|c|c|c|c|c|c|}
\hline Vila Sta. Maria & $18^{\circ} \mathrm{BPM} / \mathrm{M}$ & $2^{\mathrm{a}} \mathrm{Cia}$ & $\begin{array}{l}\text { Av. Gaspar Vaz da } \\
\text { Cunha, } 113\end{array}$ & $3936-1065 / 1104$ & $40 \mathrm{seg}, 190$ \\
\hline Vila Brasilândia & $18^{\circ} \mathrm{BPM} / \mathrm{M}$ & $3^{\mathrm{a}} \mathrm{Cia}$ & $\begin{array}{l}\text { Rua Joaquim Ferreira } \\
\text { da Rocha, } 403\end{array}$ & $3921-7611$ & $2 \min 10 \mathrm{seg}, 190$ \\
\hline Taipas & $18^{\circ} \mathrm{BPM} / \mathrm{M}$ & $4^{\mathrm{a}} \mathrm{Cia}$ & \begin{tabular}{|l} 
Estrada de Taipas, \\
2430
\end{tabular} & $3942-2343$ & $20 \mathrm{seg}, 190$ \\
\hline Limão & $18^{\circ} \mathrm{BPM} / \mathrm{M}$ & Cia FT & $\begin{array}{l}\text { Rua Vitório Trimon, } \\
26\end{array}$ & $3856-9551$ & $\begin{array}{l}1 \mathrm{~min} 50 \mathrm{seg}, 3931- \\
7913\end{array}$ \\
\hline Vila Nova York & $19^{\circ} \mathrm{BPM} / \mathrm{M}$ & Sede & $\begin{array}{l}\text { Av. Rio das Pedras, } \\
2367\end{array}$ & $\begin{array}{l}6721-4835 / 4825 \\
6721-4881 \\
\end{array}$ & $10 \mathrm{seg}, 190$ \\
\hline Vila Rica & $19^{\circ} \mathrm{BPM} / \mathrm{M}$ & $1^{\mathrm{a}} \mathrm{Cia}$ & $\begin{array}{l}\text { Av. Inconfidência } \\
\text { Mineira, } 688\end{array}$ & $\begin{array}{l}6724-8250 \\
6723-1023\end{array}$ & $\begin{array}{l}50 \mathrm{seg}, 3030-6477 \\
\text { (secretaria do meio } \\
\text { ambiente) }\end{array}$ \\
\hline São Mateus & $19^{\circ} \mathrm{BPM} / \mathrm{M}$ & $2^{\mathrm{a}} \mathrm{Cia}$ & $\begin{array}{l}\text { Av. Ragueb Chohfi, } \\
730 / 830\end{array}$ & $6722-5288$ & $50 \mathrm{seg}, 190$ \\
\hline $\begin{array}{l}\text { Dentro do } \\
\text { Terminal São } \\
\text { Mateus }\end{array}$ & $19^{\circ} \mathrm{BPM} / \mathrm{M}$ & $3^{\mathrm{a}} \mathrm{Cia}$ & $\begin{array}{l}\text { Av. Abelia Chohfi, } \\
100\end{array}$ & $6109-2477$ & $\begin{array}{l}2 \min 5 \mathrm{seg}, 0800- \\
156315\end{array}$ \\
\hline $\begin{array}{l}\text { Barueri/Jardim } \\
\text { São Pedro }\end{array}$ & $20^{\circ} \mathrm{BPM} / \mathrm{M}$ & Sede & Rua Caim, 181 & $4198-3300 / 2828$ & $\begin{array}{l}25 \text { seg, 3106-0770 } \\
\text { (não existe) }\end{array}$ \\
\hline $\begin{array}{l}\text { Barueri/Parque } \\
\text { dos Camargos }\end{array}$ & $20^{\circ} \mathrm{BPM} / \mathrm{M}$ & $1^{\mathrm{a}} \mathrm{Cia}$ & Av. Zélia, 1330 & $4201-3224$ & $\begin{array}{l}1 \mathrm{~min} 5 \mathrm{seg}, 4198- \\
3300\end{array}$ \\
\hline $\begin{array}{l}\text { Santana do } \\
\text { Parnaíba/Centro }\end{array}$ & $20^{\circ} \mathrm{BPM} / \mathrm{M}$ & $2^{\mathrm{a}} \mathrm{Cia}$ & $\begin{array}{l}\text { Rua Prof. Edgard de } \\
\text { Moraes, } 22\end{array}$ & $4154-1550 / 1380$ & $\begin{array}{l}1 \mathrm{~min}, 4155-2847 \mathrm{e} \\
4198-2828\end{array}$ \\
\hline $\begin{array}{l}\text { Itapevi/Vila } \\
\text { Nova }\end{array}$ & $20^{\circ} \mathrm{BPM} / \mathrm{M}$ & $3^{\mathrm{a}} \mathrm{Cia}$ & \begin{tabular}{|l|} 
Av. Presidente \\
Vargas, 555 \\
\end{tabular} & $4141-3231 / 3810$ & $10 \mathrm{seg}, 181$ \\
\hline Jandira/Centro & $20^{\circ} \mathrm{BPM} / \mathrm{M}$ & $4^{\mathrm{a}} \mathrm{Cia}$ & Rua João Balestero, 1 & $4707-6014 / 4683$ & $5 \mathrm{seg}, 181$ \\
\hline Moóca & $21^{\circ} \mathrm{BPM} / \mathrm{M}$ & Sede & Rua Dias Lemes, 199 & $\begin{array}{l}6605-9660 / 9591 \\
6605-1114 / 2863 \\
\end{array}$ & $\begin{array}{l}40 \text { seg, } 0800-177070 \\
\text { (correto) }\end{array}$ \\
\hline Moóca & $21^{\circ} \mathrm{BPM} / \mathrm{M}$ & $1^{\mathrm{a}} \mathrm{Cia}$ & $\begin{array}{l}\text { Rua Prof. Jacob } \\
\text { Penteado, } 129\end{array}$ & $6215-0379$ & $1 \mathrm{~min} 55 \mathrm{seg}, 102$ \\
\hline Vila Diva & $21^{\circ} \mathrm{BPM} / \mathrm{M}$ & $2^{\mathrm{a}} \mathrm{Cia}$ & $\begin{array}{l}\text { Rua Armando Dias, } \\
75\end{array}$ & \begin{tabular}{|l|}
$6918-7487$ \\
$6211-7626$ \\
$6107-2200$ \\
$6106-4211$ \\
\end{tabular} & $1 \mathrm{~min} 20 \mathrm{seg}, 190$ \\
\hline $\begin{array}{l}\text { Parque São } \\
\text { Lucas }\end{array}$ & $21^{\circ} \mathrm{BPM} / \mathrm{M}$ & $3^{\mathrm{a}} \mathrm{Cia}$ & $\begin{array}{l}\text { Rua José Macedo, } \\
166\end{array}$ & $\begin{array}{l}6107-7161 \\
6211-1878 \\
\end{array}$ & $30 \mathrm{seg}, 190$ \\
\hline Jardim Avelino & $21^{\circ} \mathrm{BPM} / \mathrm{M}$ & $4^{\mathrm{a}} \mathrm{Cia}$ & $\begin{array}{l}\text { Rua Caetano Pimentel } \\
\text { Vabo, } 46\end{array}$ & $\begin{array}{l}6346-2628 \\
6346-3286 \\
\end{array}$ & 177070 (correto) \\
\hline Água Rasa & $21^{\circ} \mathrm{BPM} / \mathrm{M}$ & $5^{\mathrm{a}} \mathrm{Cia}$ & $\begin{array}{l}\text { Rua Major Basílio, } \\
774\end{array}$ & $6675-0295$ & $\begin{array}{l}45 \text { seg, 3322-0190 e } \\
3322-0192\end{array}$ \\
\hline Vila Formosa & $21^{\circ} \mathrm{BPM} / \mathrm{M}$ & $6^{\mathrm{a}} \mathrm{Cia}$ & Rua Saigon, 201 & $6605-2569$ & $20 \mathrm{seg}, 190$ \\
\hline $\begin{array}{l}\text { Jardim } \\
\text { Marajoara }\end{array}$ & $22^{\circ} \mathrm{BPM} / \mathrm{M}$ & Sede & $\begin{array}{l}\text { Rua Dr. Paulo Ayres } \\
\text { Neto, } 110\end{array}$ & \begin{tabular}{|l}
$5521-2310 / 1300$ \\
$5521-1207$ \\
$5548-9549$
\end{tabular} & $\begin{array}{l}20 \text { seg, 3241-5044 } \\
\text { (departamento } \\
\text { disciplinar da } \\
\text { Polícia Militar) }\end{array}$ \\
\hline Santo Amaro & $22^{\circ} \mathrm{BPM} / \mathrm{M}$ & $1^{\mathrm{a}} \mathrm{Cia}$ & $\begin{array}{l}\text { Rua Dr Antonio } \\
\text { Bento, } 231\end{array}$ & \begin{tabular}{|l|}
$5522-9479 / 9402$ \\
$210-0023$ \\
$5691-0158$ \\
\end{tabular} & $1 \mathrm{~min} 55 \mathrm{seg}, 190$ \\
\hline
\end{tabular}




\begin{tabular}{|c|c|c|c|c|c|}
\hline Jardim Miriam & $22^{\circ} \mathrm{BPM} / \mathrm{M}$ & $2^{\mathrm{a}} \mathrm{Cia}$ & Av. Cupecê, 5934 & \begin{tabular}{|l|}
$5625-2333 / 2223$ \\
5622
\end{tabular} & $\begin{array}{l}\text { 30 seg, 0800-177070 } \\
\text { (correto) }\end{array}$ \\
\hline Cidade Ademar & $22^{\circ} \mathrm{BPM} / \mathrm{M}$ & $3^{\mathrm{a}} \mathrm{Cia}$ & $\begin{array}{l}\text { Rua Cel Francisco } \\
\text { Júlio César Alfieri, } 83\end{array}$ & \begin{tabular}{|l|}
$5565-5652 / 4511$ \\
$5671-6556$
\end{tabular} & $5 \mathrm{seg}, 190$ \\
\hline Vila Joaniza & $22^{\circ} \mathrm{BPM} / \mathrm{M}$ & $4^{\mathrm{a}} \mathrm{Cia}$ & $\begin{array}{l}\text { Av. Yervant } \\
\text { Kissajikian, } 2215\end{array}$ & $\begin{array}{l}5625-5600 / 7722 \\
5620-0527 \\
5626-1666 \\
\end{array}$ & $\begin{array}{l}50 \mathrm{seg}, 0800- \\
7706190\end{array}$ \\
\hline Santo Amaro & $22^{\circ} \mathrm{BPM} / \mathrm{M}$ & $5^{\mathrm{a}} \mathrm{Cia}$ & Rua Ângelo Herrero & \begin{tabular}{|l|}
$5548-8778 / 6637$ \\
$5695-0026 / 0027$ \\
\end{tabular} & $45 \mathrm{seg}, 190$ \\
\hline Santo Amaro & $22^{\circ} \mathrm{BPM} / \mathrm{M}$ & Cia FT & $\begin{array}{l}\text { Rua Padre José de } \\
\text { Ancheita, } 138\end{array}$ & $5687-2625$ & $30 \mathrm{seg}, 190$ \\
\hline Vila Beatriz & $23^{\circ} \mathrm{BPM} / \mathrm{M}$ & Sede & $\begin{array}{l}\text { Rua Alfredo Piragibe, } \\
300\end{array}$ & \begin{tabular}{|l|}
$3034-3199 / 3533$ \\
$3032-0686$
\end{tabular} & $\begin{array}{l}2 \mathrm{~min} 50 \text { seg, } 6978- \\
3069 \text { (corregedoria) }\end{array}$ \\
\hline City Boaçava & $23^{\circ} \mathrm{BPM} / \mathrm{M}$ & $1^{\mathrm{a}} \mathrm{Cia}$ & $\begin{array}{l}\text { Av. Prof. Fonseca } \\
\text { Rodrigues, } 1655\end{array}$ & \begin{tabular}{|l}
$3023-1125$ \\
$3021-9648$ \\
$3022-5185$
\end{tabular} & $35 \mathrm{seg}, 181$ \\
\hline Perdizes & $23^{\circ} \mathrm{BPM} / \mathrm{M}$ & $2^{\mathrm{a}} \mathrm{Cia}$ & Rua Itapicuru, 80 & $3862-2887 / 2071$ & 45 seg, 3322-0190 \\
\hline Itaim Bibi & $23^{\circ} \mathrm{BPM} / \mathrm{M}$ & $3^{\mathrm{a}} \mathrm{Cia}$ & \begin{tabular}{|l} 
Rua Jesuino de \\
Arruda, 464
\end{tabular} & \begin{tabular}{|l|}
$3079-7695 / 5008$ \\
$3167-1901$ \\
\end{tabular} & 177070 (correto) \\
\hline Pinheiros & $23^{\circ} \mathrm{BPM} / \mathrm{M}$ & Cia FT & $\begin{array}{l}\text { Rua Dep. Lacerda } \\
\text { Franco, } 140\end{array}$ & $3812-0943 / 3785$ & $20 \mathrm{seg}, 190$ \\
\hline $\begin{array}{l}\text { Diadema/Jardim } \\
\text { Conceição }\end{array}$ & $24^{\circ} \mathrm{BPM} / \mathrm{M}$ & Sede & $\begin{array}{l}\text { Av. Nossa Senhora } \\
\text { das Vitórias, } 106\end{array}$ & \begin{tabular}{|l|}
$4057-1010 / 3423$ \\
$3557 / 3602$ \\
$4051-1288$ \\
\end{tabular} & (correto) \\
\hline \begin{tabular}{|l} 
Diadema/ \\
Taboão \\
\end{tabular} & $24^{\circ} \mathrm{BPM} / \mathrm{M}$ & $1^{\mathrm{a}} \mathrm{Cia}$ & $\begin{array}{l}\text { Av. Prestes Maia, } \\
1941\end{array}$ & $4091-5106$ & $1 \mathrm{~min} 15 \mathrm{seg}, 190$ \\
\hline $\begin{array}{l}\text { Diadema/Vila } \\
\text { São José }\end{array}$ & $24^{\circ} \mathrm{BPM} / \mathrm{M}$ & $2^{\mathrm{a}} \mathrm{Cia}$ & $\begin{array}{l}\text { Rua Barão de Iguape, } \\
64\end{array}$ & $4077-3800$ & $45 \mathrm{seg}, 4057-1010$ \\
\hline $\begin{array}{l}\text { Diadema/ } \\
\text { Jardim Eldorado }\end{array}$ & $24^{\circ} \mathrm{BPM} / \mathrm{M}$ & $3^{\mathrm{a}} \mathrm{Cia}$ & $\begin{array}{l}\text { Rua Manoel Mota, } \\
340\end{array}$ & $4043-5057$ & $45 \mathrm{seg}, 190$ \\
\hline \begin{tabular}{|l} 
Itapecerica da \\
Serra \\
\end{tabular} & $25^{\circ} \mathrm{BPM} / \mathrm{M}$ & Sede & Rua Taquaral, 28 & \begin{tabular}{|l|}
$4666-3637 / 3677$ \\
$/ 2422 / 7725$ \\
\end{tabular} & 177070 (correto) \\
\hline $\begin{array}{l}\text { Itapecerica da } \\
\text { Serra } \\
\end{array}$ & $25^{\circ} \mathrm{BPM} / \mathrm{M}$ & $1^{\mathrm{a}} \mathrm{Cia}$ & & $4667-7888 / 7889$ & (correto) \\
\hline Embu-Guaçú & $25^{\circ} \mathrm{BPM} / \mathrm{M}$ & $2^{\mathrm{a}} \mathrm{Cia}$ & & $\begin{array}{l}4661-3524 \\
4662-1072 \\
\end{array}$ & $10 \mathrm{seg}, 4666-2422$ \\
\hline Juquitiba & $25^{\circ} \mathrm{BPM} / \mathrm{M}$ & $2^{\circ}$ Pel. & & $4681-4144$ & $40 \mathrm{seg}, 0800-156315$ \\
\hline São Lourenço & $25^{\circ} \mathrm{BPM} / \mathrm{M}$ & $1^{\circ} \mathrm{GP}$ & & $4686-1480$ & (correto) \\
\hline $\begin{array}{l}\text { Franco da } \\
\text { Rocha/Complex } \\
\text { o Juqueri } \\
\end{array}$ & $26^{\circ} \mathrm{BPM} / \mathrm{M}$ & Sede & Al. dos Coqueiros, 26 & $\begin{array}{l}4449-3848 / 2942 \\
4443-6505\end{array}$ & $\begin{array}{l}15 \mathrm{seg}, 4443-6502 \mathrm{e} \\
4443-6507\end{array}$ \\
\hline \begin{tabular}{|l} 
Franco da \\
Rocha/Centro
\end{tabular} & $26^{\circ} \mathrm{BPM} / \mathrm{M}$ & $1^{\mathrm{a}} \mathrm{Cia}$ & $\begin{array}{l}\text { Rua Dr. Franco da } \\
\text { Rocha, } 201\end{array}$ & $4449-5057$ & $10 \mathrm{seg}, 181$ \\
\hline $\begin{array}{l}\text { Mairiporã/ } \\
\text { Centro }\end{array}$ & $26^{\circ} \mathrm{BPM} / \mathrm{M}$ & $2^{\mathrm{a}} \mathrm{Cia}$ & Al. Tibiriçá, 214 & $4604-2080$ & (correto) \\
\hline $\begin{array}{l}\text { Cajamar/ } \\
\text { Jordanésia }\end{array}$ & $26^{\circ} \mathrm{BPM} / \mathrm{M}$ & $3^{\mathrm{a}} \mathrm{Cia}$ & Rua Bauru, 200 & $4447-5703$ & $\begin{array}{l}0800-177070 \\
\text { correto) }\end{array}$ \\
\hline
\end{tabular}




\begin{tabular}{|c|c|c|c|c|c|}
\hline $\begin{array}{l}\text { Francisco } \\
\text { Morato/Centro }\end{array}$ & $26^{\circ} \mathrm{BPM} / \mathrm{M}$ & $4^{\mathrm{a}} \mathrm{Cia}$ & Rua 21 de Março, 530 & $4488-8622$ & $20 \mathrm{seg}, 102$ \\
\hline Caieras/Centro & $26^{\circ} \mathrm{BPM} / \mathrm{M}$ & $5^{\mathrm{a}} \mathrm{Cia}$ & $\begin{array}{l}\text { Av. Prof. Carvalho } \\
\text { Pinto, } 207\end{array}$ & $4605-2009$ & $\begin{array}{l}1 \mathrm{~min} 15 \mathrm{seg}, 3327- \\
7000\end{array}$ \\
\hline $\begin{array}{l}\text { Parque América } \\
\text { - Grajaú }\end{array}$ & $27^{\circ} \mathrm{BPM} / \mathrm{M}$ & $\begin{array}{l}\text { Sede } \\
1^{\text {a }} \text { Cia }\end{array}$ & $\begin{array}{l}\text { Rua Rosália Griff } \\
\text { Sandoval, } 270\end{array}$ & \begin{tabular}{|l|}
$5928-1414 / 0973$ \\
$5928-9337$ \\
$5929-2276$ \\
\end{tabular} & $15 \mathrm{seg}, 102$ e 190 \\
\hline Parelheiros & $27^{\circ} \mathrm{BPM} / \mathrm{M}$ & $2^{\mathrm{a}} \mathrm{Cia}$ & $\begin{array}{l}\text { Av. Sadamus Inoue, } \\
180\end{array}$ & $5921-9935$ & $55 \mathrm{seg}, 190$ \\
\hline Interlagos & $27^{\circ} \mathrm{BPM} / \mathrm{M}$ & $\begin{array}{l}3^{\text {a }} \text { Cia } \\
\text { Cia FT }\end{array}$ & $\begin{array}{l}\text { Av. Senador Teotônio } \\
\text { Vilela, } 37\end{array}$ & 5973-9331 & $20 \mathrm{seg}, 102$ \\
\hline $\begin{array}{l}\text { Parque do } \\
\text { Carmo }\end{array}$ & $28^{\circ} \mathrm{BPM} / \mathrm{M}$ & Sede & \begin{tabular}{|l|} 
Rua Manoel \\
Sarmento, 249
\end{tabular} & \begin{tabular}{|l|}
$6748-0190$ \\
regina \\
$6748-5780 / 7228$
\end{tabular} & $1 \min 5 \mathrm{seg}, 190$ \\
\hline Guaianazes & $28^{\circ} \mathrm{BPM} / \mathrm{M}$ & $1^{\mathrm{a}} \mathrm{Cia}$ & $\begin{array}{l}\text { Rua Salvador } \\
\text { Gianetti, } 386\end{array}$ & $6557-0347$ & $\begin{array}{l}1 \mathrm{~min} 45 \mathrm{seg}, 0800- \\
177070 \text { (correto) }\end{array}$ \\
\hline $\begin{array}{l}\text { Colônia } \\
\text { Japonesa }\end{array}$ & $28^{\circ} \mathrm{BPM} / \mathrm{M}$ & $2^{\mathrm{a}} \mathrm{Cia}$ & $\begin{array}{l}\text { Av. Nova } \\
\text { Trabalhadores - Jacú } \\
\text { Pêssego, } 2708\end{array}$ & $6521-7325$ & $50 \mathrm{seg}, 190$ \\
\hline $\begin{array}{l}\text { Cidade } \\
\text { Tiradentes }\end{array}$ & $28^{\circ} \mathrm{BPM} / \mathrm{M}$ & $3^{\mathrm{a}} \mathrm{Cia}$ & $\begin{array}{l}\text { Av. dos Metalúrgicos, } \\
150\end{array}$ & $6964-8120$ & $5 \mathrm{seg}, 183$ \\
\hline $\begin{array}{l}\text { Cidade } \\
\text { Tiradentes }\end{array}$ & $28^{\circ} \mathrm{BPM} / \mathrm{M}$ & $4^{\mathrm{a}} \mathrm{Cia}$ & $\begin{array}{l}\text { Rua Ernesto Gold, } \\
305\end{array}$ & 6964-2248 & \\
\hline $\begin{array}{l}\text { São Miguel } \\
\text { Paulista }\end{array}$ & $29^{\circ} \mathrm{BPM} / \mathrm{M}$ & $\begin{array}{l}\text { Sede } \\
\text { Cia FT }\end{array}$ & $\begin{array}{l}\text { Av. Dr José Arthur da } \\
\text { Nova, } 917\end{array}$ & \begin{tabular}{|l|}
$6137-2219$ P1 \\
$6130-1155$ \\
$6131-5429 / 5057$ \\
\end{tabular} & 40 seg, 3327-7000 \\
\hline Jardim Robru & $29^{\circ} \mathrm{BPM} / \mathrm{M}$ & $1^{\mathrm{a}} \mathrm{Cia}$ & $\begin{array}{l}\text { Rua Paulino Pacheco } \\
\text { de Melo 3A }\end{array}$ & $6135-0829$ & (correto) \\
\hline $\begin{array}{l}\text { São Miguel } \\
\text { Paulista }\end{array}$ & $29^{\circ} \mathrm{BPM} / \mathrm{M}$ & $2^{\mathrm{a}} \mathrm{Cia}$ & Av. Nordestina, 415 & $6131-2523$ & $50 \mathrm{seg}, 190$ \\
\hline Jardim Helena & $29^{\circ} \mathrm{BPM} / \mathrm{M}$ & $3^{\mathrm{a}} \mathrm{Cia}$ & $\begin{array}{l}\text { Av. Prof. Alípio de } \\
\text { Barros, } 611\end{array}$ & $\begin{array}{l}6584-2330 \\
6585-4031 \\
\end{array}$ & $\begin{array}{l}2 \min 20 \mathrm{seg}, 0800- \\
555190(\mathrm{PM})\end{array}$ \\
\hline Itaim Paulista & $29^{\circ} \mathrm{BPM} / \mathrm{M}$ & $4^{\mathrm{a}} \mathrm{Cia}$ & \begin{tabular}{|l} 
Av. Tibúrcio de \\
Souza, 860
\end{tabular} & $6963-8999$ & $50 \mathrm{seg}, 6137-2219$ \\
\hline $\begin{array}{l}\text { Mauá/Parque } \\
\text { São Vicente }\end{array}$ & $30^{\circ} \mathrm{BPM} / \mathrm{M}$ & Sede & $\begin{array}{l}\text { Av. Papa João XXIII, } \\
528-A\end{array}$ & \begin{tabular}{|l}
$4546-3196 / 3197$ \\
$/ 3198 / 3199$
\end{tabular} & 177070 (correto) \\
\hline Mauá & $30^{\circ} \mathrm{BPM} / \mathrm{M}$ & $1^{\mathrm{a}} \mathrm{Cia}$ & & $4555-1010$ & $20 \mathrm{seg}, 102$ \\
\hline Ribeirão Pires & $30^{\circ} \mathrm{BPM} / \mathrm{M}$ & $2^{\mathrm{a}} \mathrm{Cia}$ & & $4828-1010$ & (correto) \\
\hline Mauá & $30^{\circ} \mathrm{BPM} / \mathrm{M}$ & $3^{\mathrm{a}} \mathrm{Cia}$ & & $4544-7390$ & $30 \mathrm{seg}, 4544-7054$ \\
\hline $\begin{array}{l}\text { Guarulhos/ } \\
\text { Haroldo Veloso }\end{array}$ & $31^{\circ} \mathrm{BPM} / \mathrm{M}$ & Sede & Av. Candeia, 400 & $\begin{array}{l}6467-2768 / 1929 \\
/ 2158\end{array}$ & $\begin{array}{l}2 \text { min } 45 \mathrm{seg}, 6463- \\
5555 \text { (Copom } \\
\text { Guarulhos) }\end{array}$ \\
\hline Guarulhos & $31^{\circ} \mathrm{BPM} / \mathrm{M}$ & $1^{\mathrm{a}} \mathrm{Cia}$ & & 6484-2901/2607 & $\begin{array}{l}1 \mathrm{~min} 50 \mathrm{seg}, 3322- \\
0190\end{array}$ \\
\hline Guarulhos & $31^{\circ} \mathrm{BPM} / \mathrm{M}$ & $2^{\mathrm{a}} \mathrm{Cia}$ & & $6432-3070$ & 177070 (correto) \\
\hline Guarulhos & $31^{\circ} \mathrm{BPM} / \mathrm{M}$ & $\begin{array}{l}3^{\mathrm{a}} \text { e } 4^{\mathrm{a}} \\
\mathrm{Cia}\end{array}$ & & $6440-4674$ & $25 \mathrm{seg}, 6461-3281$ \\
\hline
\end{tabular}




\begin{tabular}{|c|c|c|c|c|c|}
\hline $\begin{array}{l}\text { Suzano/Monte } \\
\text { Cristo }\end{array}$ & $32^{\circ} \mathrm{BPM} / \mathrm{M}$ & $\begin{array}{l}\text { Sede } \\
1^{\text {a }} \mathrm{Cia}\end{array}$ & Av. Paulista, 171 & \begin{tabular}{|l}
$4742-9342$ \\
$4748-7580 / 7891$ \\
$/ 7253 / 8566$
\end{tabular} & $\begin{array}{l}2 \text { min } 35 \text { seg, } 3322- \\
0190 \text { e } 6978-3069 \\
\text { (corregedoria) }\end{array}$ \\
\hline Poá & $32^{\circ} \mathrm{BPM} / \mathrm{M}$ & $2^{\mathrm{a}} \mathrm{Cia}$ & & $\begin{array}{l}4636-2147 \\
4639-9966\end{array}$ & $\begin{array}{l}1 \mathrm{~min}, 0800-555190 \\
(\mathrm{PM})\end{array}$ \\
\hline $\begin{array}{l}\text { Ferraz de } \\
\text { Vasconcelos }\end{array}$ & $32^{\circ} \mathrm{BPM} / \mathrm{M}$ & $3^{\mathrm{a}} \mathrm{Cia}$ & & $\begin{array}{l}4678-1782 \\
4678-2666\end{array}$ & $10 \mathrm{seg}, 181$ \\
\hline $\begin{array}{l}\text { Carapicuíba/ } \\
\text { Vila Cristina }\end{array}$ & $33^{\circ} \mathrm{BPM} / \mathrm{M}$ & Sede & Rua Inajá, 14 & $\begin{array}{l}\text { 4169-6218/8287 } \\
/ 7615 / 7651\end{array}$ & $\begin{array}{l}25 \mathrm{seg}, 4184-7852 \\
\text { (Central de } \\
\text { operações) }\end{array}$ \\
\hline $\begin{array}{l}\text { Carapicuíba/ } \\
\text { Vila Dirce } \\
\end{array}$ & $33^{\circ} \mathrm{BPM} / \mathrm{M}$ & $1^{\mathrm{a}} \mathrm{Cia}$ & $\begin{array}{l}\text { Av. Inocêncio } \\
\text { Seráfico, } 3601\end{array}$ & $\begin{array}{l}4207-1916 \\
4207-2015 \\
\end{array}$ & $55 \mathrm{seg}, 190$ \\
\hline $\begin{array}{l}\text { Carapicuíba/ } \\
\text { Cohab II }\end{array}$ & $33^{\circ} \mathrm{BPM} / \mathrm{M}$ & $2^{\mathrm{a}} \mathrm{Cia}$ & Av. Amazonas, 40 & \begin{tabular}{|l|}
$4184-2760$ \\
$4184-5042$ \\
$4184-7852$ \\
\end{tabular} & $5 \mathrm{seg}, 181$ \\
\hline Cotia/ Centro & $33^{\circ} \mathrm{BPM} / \mathrm{M}$ & $3^{\mathrm{a}} \mathrm{Cia}$ & $\begin{array}{l}\text { Rua Batista Cepelos, } \\
181\end{array}$ & $\begin{array}{l}4614-6707 / \\
7747\end{array}$ & $\begin{array}{l}3 \text { min } 5 \text { seg, 3327- } \\
7000\end{array}$ \\
\hline $\begin{array}{l}\text { Carapicuíba/ } \\
\text { Vila Cristina }\end{array}$ & $33^{\circ} \mathrm{BPM} / \mathrm{M}$ & $4^{\mathrm{a}} \mathrm{Cia}$ & Rua Ibaiti, 12-A & $\begin{array}{l}4169-6218 / 8287 \\
/ 6561\end{array}$ & $\begin{array}{l}1 \mathrm{~min} 35 \mathrm{seg}, 6281- \\
9406 \text { e } 3327-7358 \\
\text { (corregedoria) }\end{array}$ \\
\hline Bresser & $34^{\circ} \mathrm{BPM} / \mathrm{M}$ & $\begin{array}{l}\text { Sede } \\
4^{\mathrm{a}} \mathrm{Cia}\end{array}$ & $\begin{array}{l}\text { Rua Visconde de } \\
\text { Parnaíba, } 2334\end{array}$ & $\begin{array}{l}6694-2049 / 2316 \\
6694-1335 \\
6618-1045 / 1110\end{array}$ & $30 \mathrm{seg}, 190$ \\
\hline Canindé & $34^{\circ} \mathrm{BPM} / \mathrm{M}$ & $1^{\mathrm{a}} \mathrm{Cia}$ & Rua Azurita, 98 & $3226-4326$ & \\
\hline Butantã & $34^{\circ} \mathrm{BPM} / \mathrm{M}$ & $2^{\mathrm{a}} \mathrm{Cia}$ & $\begin{array}{l}\text { Rua Afrânio Peixoto, } \\
309\end{array}$ & $3031-4508$ & $30 \mathrm{seg}, 102$ e 190 \\
\hline Água Rasa & $34^{\circ} \mathrm{BPM} / \mathrm{M}$ & $3^{\mathrm{a}} \mathrm{Cia}$ & $\begin{array}{l}\text { Rua Regente Feijó, } \\
871\end{array}$ & $\begin{array}{l}6121- \\
3844 / 6128-1388\end{array}$ & $30 \mathrm{seg}, 181$ \\
\hline $\begin{array}{l}\text { Itaquaquecetuba/ } \\
\text { Vila Virgínia }\end{array}$ & $35^{\circ} \mathrm{BPM} / \mathrm{M}$ & Sede & Av. Uberaba, 83 & $\begin{array}{l}4640-1256 / 1698 \\
4642-4100 / 1818 \\
\end{array}$ & $35 \mathrm{seg}, 3322-0190$ \\
\hline $\begin{array}{l}\text { Itaquaquecetuba/ } \\
\text { Monte Belo }\end{array}$ & $35^{\circ} \mathrm{BPM} / \mathrm{M}$ & $1^{\mathrm{a}} \mathrm{Cia}$ & Rua Campinas, 185 & $4642-1068 / 2382$ & $\begin{array}{l}35 \mathrm{seg}, 4640-1256 \mathrm{e} \\
181\end{array}$ \\
\hline Arujá/Centro & $35^{\circ} \mathrm{BPM} / \mathrm{M}$ & $2^{\mathrm{a}} \mathrm{Cia}$ & Av. João Manuel, 181 & $4655-2812$ & $15 \mathrm{seg}, 3322-0190$ \\
\hline $\begin{array}{l}\text { Itaquaquecetuba/ } \\
\text { Jardim Silvestre }\end{array}$ & $35^{\circ} \mathrm{BPM} / \mathrm{M}$ & $3^{\mathrm{a}} \mathrm{Cia}$ & \begin{tabular}{|l} 
Estrada de Santa \\
Isabel, 6855
\end{tabular} & \begin{tabular}{|l|}
$4648-6027$ \\
$4648-8720$ \\
\end{tabular} & $10 \mathrm{seg}, 151$ \\
\hline $\begin{array}{l}\text { Santa Isabel/ } \\
\text { Centro }\end{array}$ & $35^{\circ} \mathrm{BPM} / \mathrm{M}$ & $2^{\circ}$ Pel. & Av. República, 110 & $4656-2662 / 4809$ & $5 \mathrm{seg}, 181$ \\
\hline $\begin{array}{l}\text { Campo Limpo/ } \\
\text { Santa Emília }\end{array}$ & $36^{\circ} \mathrm{BPM} / \mathrm{M}$ & Sede & \begin{tabular}{|l} 
Estrada de \\
Itapecerica, 13053
\end{tabular} & $\begin{array}{l}4782-4715 / 1736 \\
4244-3151\end{array}$ & $5 \mathrm{~min} 15 \mathrm{seg}, 190$ \\
\hline $\begin{array}{l}\text { Embu/Jardim } \\
\text { Pinheirinho } \\
\end{array}$ & $36^{\circ} \mathrm{BPM} / \mathrm{M}$ & $\begin{array}{c}1^{\mathrm{a}}{\mathrm{e} 3^{\mathrm{a}}}^{\mathrm{Cia}} \\
\end{array}$ & Rua Paineiras, 153 & $\begin{array}{l}4704-6866 \\
4781-2572 \\
\end{array}$ & $10 \mathrm{seg}, 102$ \\
\hline $\begin{array}{l}\text { Taboão da Serra/ } \\
\text { Jardim Santo } \\
\text { Onofre }\end{array}$ & $36^{\circ} \mathrm{BPM} / \mathrm{M}$ & $2^{\mathrm{a}} \mathrm{Cia}$ & \begin{tabular}{|l|} 
Rua Milton \\
Fernandes, 30
\end{tabular} & $\begin{array}{l}4138-5042 \\
4138-7233\end{array}$ & $4 \mathrm{~min} 30 \mathrm{seg}, 190$ \\
\hline \begin{tabular}{|l|} 
Jardim \\
Copacabana \\
\end{tabular} & $37^{\circ} \mathrm{BPM} / \mathrm{M}$ & Sede & \begin{tabular}{|l} 
Estrada do M'Boi \\
Mirim, 4881
\end{tabular} & $5831-2262 / 2402$ & $1 \mathrm{~min}, 102$ \\
\hline & $37^{\circ} \mathrm{BPM} / \mathrm{M}$ & $1^{\mathrm{a}} \mathrm{Cia}$ & & $5831-2412 / 2262$ & $50 \mathrm{seg}, 102$ \\
\hline & $37^{\circ} \mathrm{BPM} / \mathrm{M}$ & $2^{\mathrm{a}} \mathrm{Cia}$ & & $5517-2980$ & $15 \mathrm{seg}, 190$ \\
\hline & $37^{\circ} \mathrm{BPM} / \mathrm{M}$ & $3^{\mathrm{a}} \mathrm{Cia}$ & & $5821-3668$ & $10 \mathrm{seg}, 190$ \\
\hline
\end{tabular}




\begin{tabular}{|c|c|c|c|c|c|}
\hline & $37^{\circ} \mathrm{BPM} / \mathrm{M}$ & $4^{\mathrm{a}} \mathrm{Cia}$ & & $5821-7972$ & $50 \mathrm{seg}, 3327-7000$ \\
\hline & $37^{\circ} \mathrm{BPM} / \mathrm{M}$ & $5^{\mathrm{a}} \mathrm{Cia}$ & & $5833-9609$ & $1 \mathrm{~min}, 190$ \\
\hline $\begin{array}{l}\text { Jardim Iguatemi } \\
\text { - São Matheus }\end{array}$ & $38^{\circ} \mathrm{BPM} / \mathrm{M}$ & Sede & $\begin{array}{l}\text { Rua Francisco de } \\
\text { Melo Palheta, } 614\end{array}$ & \begin{tabular}{|l|}
$6731-6223 \mathrm{com}$ \\
$6731-7619$ P5 \\
$6736-7178$ \\
$6131-5888$ \\
\end{tabular} & $45 \mathrm{seg}, 190$ \\
\hline Terceira Divisão & $38^{\circ} \mathrm{BPM} / \mathrm{M}$ & $1^{\mathrm{a}} \mathrm{Cia}$ & $\begin{array}{l}\text { Av. Sapopemba, } \\
30505\end{array}$ & $\begin{array}{l}6734-9555 \\
6736-8516 \\
\end{array}$ & $1 \mathrm{~min} 25 \mathrm{seg}, 190$ \\
\hline São Matheus & $38^{\circ} \mathrm{BPM} / \mathrm{M}$ & $2^{\mathrm{a}} \mathrm{Cia}$ & $\begin{array}{l}\text { Av. Ragueb Chofi, } \\
830\end{array}$ & \begin{tabular}{|l|}
$6919-6858$ \\
$6114-1067$
\end{tabular} & $15 \mathrm{seg}, 190$ \\
\hline Fazenda da Juta & $38^{\circ} \mathrm{BPM} / \mathrm{M}$ & $3^{\mathrm{a}} \mathrm{Cia}$ & $\begin{array}{l}\text { Rua Agostinho } \\
\text { Luberti, } \mathrm{s} / \mathrm{n}^{\mathrm{o}}\end{array}$ & $6115-3600$ & $15 \mathrm{seg}, 190$ \\
\hline \begin{tabular}{|l} 
Jardim Iguatemi \\
- São Matheus \\
\end{tabular} & $38^{\circ} \mathrm{BPM} / \mathrm{M}$ & Cia FT & \begin{tabular}{|l|} 
Rua Francisco de \\
Melo Palheta, 614
\end{tabular} & $6736-7524 / 7352$ & $45 \mathrm{seg}, 6736-7178$ \\
\hline José Bonifácio & $39^{\circ} \mathrm{BPM} / \mathrm{M}$ & Sede & $\begin{array}{l}\text { Rua Vicente Avelar, } \\
100\end{array}$ & \begin{tabular}{|l|}
$6522-8458$ \\
$6524-2733$ \\
$6521-2853 / 6312$ \\
\end{tabular} & \begin{tabular}{|l}
$1 \mathrm{~min}, 3291-6029$ \\
$($ correto)
\end{tabular} \\
\hline Itaquera & $39^{\circ} \mathrm{BPM} / \mathrm{M}$ & $1^{\mathrm{a}} \mathrm{Cia}$ & $\begin{array}{l}\text { Av. David } \\
\text { Domingues Ferreira, } \\
02\end{array}$ & $6944-1560$ & $\begin{array}{l}45 \text { seg, } 0800-177070 \\
\text { (correto) }\end{array}$ \\
\hline Itaquera & $39^{\circ} \mathrm{BPM} / \mathrm{M}$ & $2^{\mathrm{a}} \mathrm{Cia}$ & $\begin{array}{l}\text { Av. Valdemar Tietz, } \\
1160\end{array}$ & \begin{tabular}{|l|}
$6742-1280$ \\
$6741-1454$ \\
\end{tabular} & $10 \mathrm{seg}, 190$ \\
\hline José Bonifácio & $39^{\circ} \mathrm{BPM} / \mathrm{M}$ & $3^{\mathrm{a}} \mathrm{Cia}$ & $\begin{array}{l}\text { Rua Vicente Avelar, } \\
100\end{array}$ & \begin{tabular}{|l}
$6527-0082$ \\
$6521-6312$ \\
\end{tabular} & $1 \mathrm{~min}, 190$ e 102 \\
\hline Jardim Saúde & $39^{\circ} \mathrm{BPM} / \mathrm{M}$ & $4^{\mathrm{a}} \mathrm{Cia}$ & $\begin{array}{l}\text { Rua Carlo Manelli, } \\
220\end{array}$ & $\begin{array}{l}6514-9899 \\
6135-7474 \\
\end{array}$ & $45 \mathrm{seg}, 102$ \\
\hline Itaquera & $39^{\circ} \mathrm{BPM} / \mathrm{M}$ & Cia FT & $\begin{array}{l}\text { Av. David } \\
\text { Domingues Ferreira, } \\
2\end{array}$ & $6179-5717$ & $\begin{array}{l}50 \text { seg, } 0800-177070 \\
\text { (correto) }\end{array}$ \\
\hline $\begin{array}{l}\text { São Bernardo do } \\
\text { Campo/Parque } \\
\text { Espacial }\end{array}$ & $40^{\circ} \mathrm{BPM} / \mathrm{M}$ & Sede & Rua José Romano, 73 & $4356-6066$ & $\begin{array}{l}3 \mathrm{~min} 35 \mathrm{seg}, 0800- \\
177070 \text { (correto) }\end{array}$ \\
\hline $\begin{array}{l}\text { São Bernardo do } \\
\text { Campo/Batistini }\end{array}$ & $40^{\circ} \mathrm{BPM} / \mathrm{M}$ & $1^{\mathrm{a}} \mathrm{Cia}$ & \begin{tabular}{|l|} 
Estrada Galvão \\
Bueno, 5199 \\
\end{tabular} & $4357-1918$ & $\begin{array}{l}1 \mathrm{~min} 25 \mathrm{seg}, 0800- \\
555190(\mathrm{PM})\end{array}$ \\
\hline $\begin{array}{l}\text { São Bernardo do } \\
\text { Campo/Riacho } \\
\text { Grande }\end{array}$ & $40^{\circ} \mathrm{BPM} / \mathrm{M}$ & $2^{\mathrm{a}} \mathrm{Cia}$ & Av. da Praia, s/no & $4354-7112$ & $\begin{array}{l}1 \mathrm{~min} 45 \mathrm{seg}, 0800- \\
177070 \text { (correto) }\end{array}$ \\
\hline $\begin{array}{l}\text { São Bernardo do } \\
\text { Campo/Parque } \\
\text { dos Pássaros }\end{array}$ & $40^{\circ} \mathrm{BPM} / \mathrm{M}$ & $3^{\mathrm{a}} \mathrm{Cia}$ & Av. José Donizi, 1800 & $4398-7400 / 7401$ & $\begin{array}{l}1 \text { min } 5 \text { seg, } 0800- \\
177070 \text { (correto) }\end{array}$ \\
\hline $\begin{array}{l}\text { Santo André/ } \\
\text { Jardim Bela } \\
\text { Vista }\end{array}$ & $41^{\circ} \mathrm{BPM} / \mathrm{M}$ & Sede & Rua Ilhéus, 61 & $4436-1511$ & $20 \mathrm{seg}, 190$ \\
\hline $\begin{array}{l}\text { Santo André/ } \\
\text { Jardim Bela } \\
\text { Vista }\end{array}$ & $41^{\circ} \mathrm{BPM} / \mathrm{M}$ & $1^{\mathrm{a}} \mathrm{Cia}$ & Rua Ilhéus, 61 & $4436-1010$ & $5 \mathrm{seg}, 190$ \\
\hline Santo André & $41^{\circ} \mathrm{BPM} / \mathrm{M}$ & $2^{\mathrm{a}} \mathrm{Cia}$ & Rua Sigma, s/no & $\begin{array}{l}4974-7632 \\
4972-3311 \\
\end{array}$ & 15 seg, 190 \\
\hline Santo André & $41^{\circ} \mathrm{BPM} / \mathrm{M}$ & $3^{\mathrm{a}} \mathrm{Cia}$ & Av. Guaianazes, 440 & $4474-2555$ & $30 \mathrm{seg}, 4436-1511$ \\
\hline
\end{tabular}




\begin{tabular}{|c|c|c|c|c|c|}
\hline & & & & $4474-5337$ & \\
\hline $\begin{array}{l}\text { Osasco/Jardim } \\
\text { Baronesa }\end{array}$ & $42^{\circ} \mathrm{BPM} / \mathrm{M}$ & Sede & Rua Luiz Gatti, 235 & $3686-0832$ & $1 \mathrm{~min}, 190$ \\
\hline Osasco & $42^{\circ} \mathrm{BPM} / \mathrm{M}$ & $1^{\mathrm{a}} \mathrm{Cia}$ & & $3686-4476$ & $\begin{array}{l}20 \text { seg, 3604-2888 } \\
\text { (CPA) }\end{array}$ \\
\hline Osasco & $42^{\circ} \mathrm{BPM} / \mathrm{M}$ & $2^{\mathrm{a}} \mathrm{Cia}$ & & $3602-3650$ & $1 \mathrm{~min} 5 \mathrm{seg}, 190$ \\
\hline Liberdade & CPA & M-01 & Rua Vergueiro, 363 & $3209-1430$ & 50 seg, 3327-7000 \\
\hline Aeroporto & CPA & M-02 & Rua Rafael Iorio, 160 & $\begin{array}{l}5044-5416 / 0833 \\
5531-3629\end{array}$ & $\begin{array}{l}1 \text { min } 20 \text { seg, 3291- } \\
6099 \text { (fax) e 3291- } \\
6108 \text { (não existe) }\end{array}$ \\
\hline Vila Maria & $\mathrm{CPA}$ & $\mathrm{M}-03$ & Rua Amambaí, 09 & $\begin{array}{l}\text { 6967-9803/9800 } \\
/ 9909 / 9852 \\
/ 9946\end{array}$ & $\begin{array}{l}30 \mathrm{seg}, 3106-0770 \\
\text { não existe }\end{array}$ \\
\hline Vila Esperança & $\mathrm{CPA}$ & M-04 & $\begin{array}{l}\text { Av. Amador Bueno } \\
\text { da Veiga, } 2774\end{array}$ & $6957-3432 / 4566$ & $\begin{array}{l}15 \mathrm{seg}, 3327-7121 \\
(\mathrm{CPC})\end{array}$ \\
\hline Rio Pequeno & $\mathrm{CPA}$ & M-05 & $\begin{array}{l}\text { Av. Corifeu de } \\
\text { Azevedo Marques, } \\
4082\end{array}$ & $\begin{array}{l}3769-2037 / 01 \\
3768-5947\end{array}$ & $\begin{array}{l}20 \text { seg, 3291-6000 } \\
\text { (Secretaria de } \\
\text { Segurança Pública) }\end{array}$ \\
\hline $\begin{array}{l}\text { Santo André/ } \\
\text { Vila Guiomar }\end{array}$ & $\mathrm{CPA}$ & M-06 & Rua Silveira, 20 & \begin{tabular}{|l|}
$4438-1011$ \\
$4994-3999$ \\
$4992-0171$
\end{tabular} & $\begin{array}{l}\text { 55 seg, 0800-177070 } \\
\text { (correto) 3823-5879 } \\
\text { ? e 3806-0707 (não } \\
\text { existe) }\end{array}$ \\
\hline $\begin{array}{l}\text { Guarulhos/Vila } \\
\text { Tijuco }\end{array}$ & $\mathrm{CPA}$ & M-07 & $\begin{array}{l}\text { Rua Humberto de } \\
\text { Campos, } 715\end{array}$ & $\begin{array}{l}\text { 6463-5555/5501 } \\
/ 5503\end{array}$ & $\begin{array}{l}55 \text { seg, 3291-6108 } \\
\text { (não existe) e 3823- } \\
5879\end{array}$ \\
\hline $\begin{array}{l}\text { Osasco/ } \\
\text { Rochdalle }\end{array}$ & $\mathrm{CPA}$ & M-08 & $\begin{array}{l}\text { Av. Cruzeiro do Sul, } \\
460\end{array}$ & $3604-2850 / 2888$ & $\begin{array}{l}30 \text { seg, } 0800- \\
7711175 \text { (ouvidoria } \\
\text { de Osasco) }\end{array}$ \\
\hline Vila Carmosina & $\mathrm{CPA}$ & M-09 & $\begin{array}{l}\text { Rua Menininha Lobo, } \\
51\end{array}$ & $\begin{array}{l}6523-3905 / 4151 \\
6525-0150 \\
6524-8078\end{array}$ & $\begin{array}{l}1 \mathrm{~min} 15 \mathrm{seg}, 0800- \\
190190\end{array}$ \\
\hline $\begin{array}{l}\text { Várzea de Baixo } \\
\text { - Santo Amaro }\end{array}$ & CPA & M-10 & $\begin{array}{l}\text { Rua Dr. Rubens } \\
\text { Gomes Bueno, } 231\end{array}$ & $\begin{array}{l}5641-0811 / 7182 \\
/ 7173 / 7531 \\
/ 5592 / 2747\end{array}$ & $\begin{array}{l}35 \text { seg, 230-0033 } \\
\text { (não existe) e 3327- } \\
7000\end{array}$ \\
\hline \multirow[t]{2}{*}{ Tatuapé } & CPA & M-11 & Rua São Felipe, 381 & $\begin{array}{l}6197-7419 \\
295-3592 / 3441 \\
/ 3401\end{array}$ & $\begin{array}{l}50 \text { seg, } 3823-5700 \\
\text { (ouvidoria pública) }\end{array}$ \\
\hline & $\begin{array}{r}\text { PM 1 } \\
\text { Comando }\end{array}$ & & & $3106-8436$ & $30 \mathrm{seg}, 190$ \\
\hline
\end{tabular}

Algumas reações:

- Quem está falando? Bruno. Vou ver se tenho aqui, se não tiver você vai ter que ligar no 190. Você é policial militar? Não. Ah, olha, Bruno, então você vai ter que ligar no 190. 
- Ouvidoria? Mas que ouvidoria? - Ouvidoria da polícia. - Ah, então vou passar para alguém mais indicado... - Pois não? Você quer o telefone da ouvidoria? - Sim - É para fazer alguma denúncia? - Eu gostaria de falar lá na ouvidoria. - Mas é sobre alguma denúncia? - Eu queria fazer um comentário com o pessoal lá da ouvidoria. - É que se fosse denúncia, eu ia pedir para você fazer comigo porque eu sou o comandante aqui do batalhão. A sargento vai passar o número para você... - Olha, eu não estou encontrando o telefone aqui, vou pedir para você ligar em outro número...

- Ouvidoria? Quem está falando? - Bruno. - Bruno, você pode aguardar um minutinho? ... Olha, o telefone da ouvidoria, eu não tenho aqui. Mas tenho o telefone do disque-denúncia. Você pode ligar no disque-denúncia e fazer qualquer denúncia referente à atualidade, está bem?

- Ouvidoria? Quem deseja? - Bruno. - Bruno, como a gente não usa, a gente não tem esse telefone... Faz o seguinte, liga no 190.

- Ouvidoria? Quem fala? - Bruno. - Bruno de onde? - de São Paulo. - E você quer a ouvidoria de onde, da polícia militar ou da polícia civil? - eu quero o telefone da ouvidoria da polícia. - Sim, mas você sabe que são duas polícias diferentes, a militar e a civil, não sabe? Então, você quer o telefone de que ouvidoria?

- Ouvidoria? Quem está falando? - Bruno. - Um momento... (Atende outra pessoa) - Bruno? E o senhor é de onde? - De São Paulo. - Você é PM? Não. - Ah, então espera um pouquinho... 
Tabulação dos resultados:

\begin{tabular}{|l|c|c|c|}
\hline Batalhões da Polícia Militar & $\mathbf{N}^{\mathbf{0}}$ total & $\mathbf{N}^{\mathbf{0}}$ de acertos & Porcentagem \\
\hline São Paulo - Capital & 142 & 22 & $15,5 \%$ \\
\hline Grande São Paulo & 80 & 15 & $18,8 \%$ \\
\hline Somente Grande ABC* & 25 & 7 & $28,0 \%$ \\
\hline Grande SP menos Grande ABC & 55 & 8 & $14,5 \%$ \\
\hline Total (SP + Grande SP) & $\mathbf{2 2 2}$ & $\mathbf{3 7}$ & $\mathbf{1 6 , 7 \%}$ \\
\hline
\end{tabular}

* Santo André, São Bernardo do Campo, São Caetano do Sul, Diadema, Mauá, Ribeirão Pires 


\begin{abstract}
ANEXO 6
Alguns exemplares do jornal eletrônico Otite Crônica, idealizado por Fermino Fecchio quando esteve à frente da Ouvidoria da Polícia do Estado de São Paulo, com o objetivo de romper o cerco em que foi colocado pelo governo do estado.

Incluímos aqui os exemplares $n^{0} 3$ e $n^{0} 4$ e a edição extra E2. O primeiro divulgou a informação de que apenas um quinto dos policiais militares vítimas de homicídio no Estado de São Paulo são mortos em serviço. A grande maioria deles morre durante o bico, fora do horário de serviço. O segundo mostra que o número de suicídios na PM é superior ao número de policiais mortos em serviço. Uma prova, segundo Fermino Fecchio, de que a ouvidoria não é contra a polícia. A edição extra E2, de 7 de agosto de 2002, faz graves denúncias sobre o trabalho do Grupo de Repressão e Análise dos Delitos de Intolerância (Gradi) da Polícia Militar.
\end{abstract}




\section{OTITE}

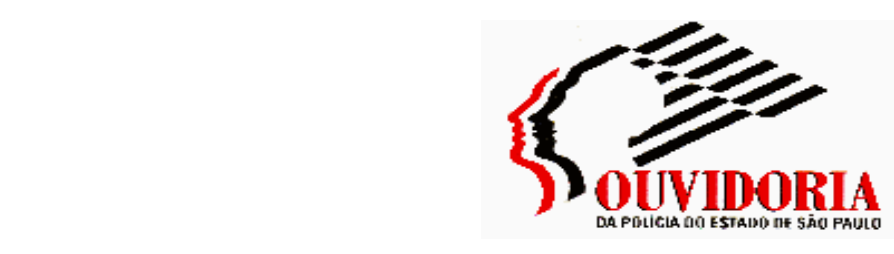

CRÔNICA

Ano $1-n^{\circ} 3-03$ de setembro a 18 de setembro de 2001

\section{Os municípios e a Segurança Pública}

Prefeitos dos municípios paulistas, reunidos em seminário, na semana passada, em Jundiaí, manifestaram sua preocupação com $o$ aumento da criminalidade $e$ da violência no interior do Estado.

Ficou demonstrado na ocasião que os cidadãos têm cobrado dos prefeitos, ações para diminuir a violência nos municípios.

Torna-se cada vez mais evidente que Segurança Pública não pode ficar, apenas, na dependência da atuação dos órgãos estaduais. É imperiosa a necessidade de ampliação da atuação dos municípios nessa tarefa, para implementar ações locais que garantam a segurança dos cidadãos

Mais do que ações emergenciais espera-se, sejam os municípios capazes de conceber uma nova relação polícia-cidadão e comunidade-polícia.

\section{Estatisticamente falando...}

Policiais Militares Vítimas de Homicídio no Estado de São Paulo

\begin{tabular}{|c|c|c|c|c|c|}
\hline \multirow{2}{*}{ Ano } & \multicolumn{2}{|c|}{ Em Servico } & \multicolumn{2}{c|}{ Folga } & \multirow{2}{*}{ Totais } \\
\cline { 2 - 5 } & Número & $\%$ & Número & $\%$ & \\
\hline 1991 & 14 & 29,79 & 33 & 70,21 & $\mathbf{4 7}$ \\
\hline 1992 & 9 & 20,45 & 35 & 79,55 & $\mathbf{4 4}$ \\
\hline 1993 & 9 & 20,93 & 34 & 79,07 & $\mathbf{4 3}$ \\
\hline 1994 & 16 & 25,81 & 46 & 74,19 & $\mathbf{6 2}$ \\
\hline 1995 & 8 & 18,18 & 36 & 81,82 & $\mathbf{4 4}$ \\
\hline 1996 & 13 & 17,57 & 61 & 82,43 & $\mathbf{7 4}$ \\
\hline 1997 & 15 & 22,39 & 52 & 77,61 & $\mathbf{6 7}$ \\
\hline 1998 & 17 & 18,09 & 77 & 81,91 & $\mathbf{9 4}$ \\
\hline 1999 & 27 & 19,71 & 110 & 80,29 & $\mathbf{1 3 7}$ \\
\hline 2000 & 25 & 18,66 & 109 & 81,34 & $\mathbf{1 3 4}$ \\
\hline Totais & $\mathbf{1 5 3}$ & $\mathbf{2 0 , 5 1}$ & $\mathbf{5 9 3}$ & $\mathbf{7 9 , 4 9}$ & $\mathbf{7 4 6}$ \\
\hline
\end{tabular}

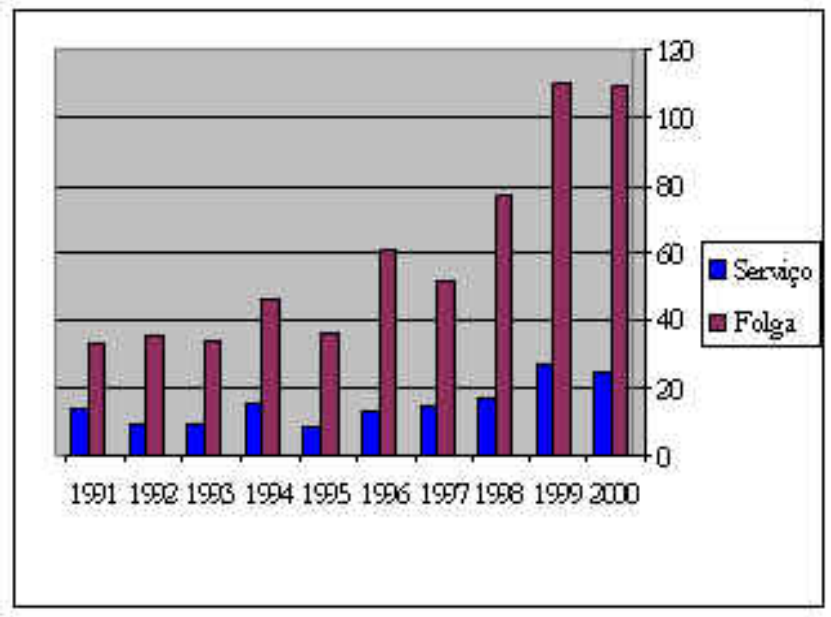

Fonte: Corregedoria da Polícia Militar do Estado de São Paulo 


\section{Pra Você Saber}

O Ouvidor da Polícia tem mandato de dois anos e é indicado para o cargo pelo CONDEPE (Conselho Estadual de Defesa dos Direitos da Pessoa Humana) e nomeado pelo Governador. O CONDEPE tem, em sua composição, representação majoritária de entidades da Sociedade Civil.

\section{É digno de nota ...}

Imagine a seguinte situação: um rapaz é preso acusado de estupro de uma menina de 11 anos. No momento da prisão, o rapaz é torturado e obrigado a vestir roupas intimas femininas, e fotografado pela imprensa. As testemunhas e a vítima reconhecem 0 acusado mas, durante 0 reconhecimento, o acusado é colocado algemado, com as mãos para frente, entre outros dois rapazes bem vestidos.

Depois de oito longos meses preso, 0 rapaz é solto, absolvido do crime que the foi imputado, graças a um exame de DNA. Durante toda fase de inquérito e processo criminal, provas documentais, como cartão de ponto fornecido pela empresa onde ele trabalhava, que atestavam sua presença na empresa no momento do crime, assim como as irregularidades da prisão $e$ do reconhecimento são ignoradas.

Sobre a atuação dos policiais no momento da prisão, é instaurada uma Sindicância submetida a apreciação do Poder Judiciário, que foi posteriormente arquivada frente à alegação dos policiais que o rapaz concordou em ser fotografado e já vestia as roupas íntimas femininas, por baixo, quando chegou à delegacia.

\section{O Ministério Público e o combate à Tortura}

A Ouvidoria não pode deixar de enaltecer a atuação firme e enérgica dos representantes do Ministério Público que ofereceram denúncia pela prática de tortura contra 18 policiais civis e 12 policiais militares, em processo crime que tramita no interior do Estado.

Após tentativa de fuga imediatamente controlada pelos carcereiros, policiais civis e militares deram início a uma longa sessão de humilhação e tortura dos presos.

A violência foi tamanha que, decorrido um mês e meio da data dos fatos, os presos foram submetidos a Exame de Corpo de Delito, e ainda apresentavam marcas das agressões sofridas.

Promotores de Justiça especialmente nomeados pelo Procurador Geral de Justiça determinaram a abertura de séria e firme investigação que foi decisiva para a apuração da atuação abusiva dos policiais, que, como agentes do Estado, deveriam garantir a integridade física e moral dos presos. 


\begin{tabular}{|} 
OUVIDORIA DA POLÍCIA \\
Ouvidor: Fermino Fecchio \\
Para denunciar: \\
Fone: 0800-177070 \\
Fax: 3823-5715 \\
E-mail: ouv-policia@ouvidoria-policia.sp.gov.br \\
Endereço: Av. Higienópolis, 758 - Higienópolis, \\
São Paulo/SP CEP 01238-000 \\
\end{tabular}

\begin{tabular}{|c||}
\hline OTITE \\
CRÔNICA \\
E-mail: informa@ouvidoria-policia.sp.9ov.br \\
Tel: 3823-5879 - Fax: 3823-5715 \\
Responsáveis: Isabel Figueiredo \\
Giordano Mochel \\
Leonardo Muniz \\
Colaborador: Pedro Mathias \\
Kathleen Scholten \\
Cláudia Sayuri Arie \\
\hline
\end{tabular}




\section{OTITE \\ CROANICA}

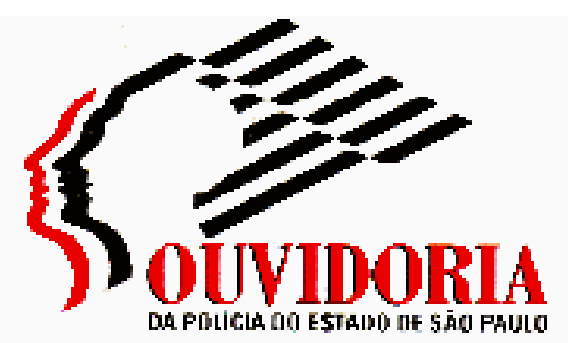

Ano $1-n^{\circ} 4-18$ de setembro a 2 de outubro de 2001

\section{O povo tem medo da policia?}

Diariamente, nesta Ouvidoria, recolhemos inúmeros depoimentos que, de certa forma, comprovam o medo que as pessoas têm em relação à polícia.

Porém só afirmar que o povo tem medo da polícia não reflete toda a realidade. A mesma parcela que diz ter medo da polícia é a que mais reclama de falta de policiamento no seu bairro, na sua rua, e que pede policiamento na escola de seu filho.

Parece lógico concluir, portanto, que o povo tem medo da truculência dos policiais, mas quer a policia ao seu lado - uma polícia bem preparada e treinada. Equipada e, sobretudo, educada, amiga, capaz de ajudar a reduzir a violência e garantir a segurança.

Casos lamentáveis, como o do perueiro criminosamente executado por policiais, só aumentam o medo das pessoas e não ajudam em nada à segurança pública.

\section{Fermino Fecchio}

Ouvidor da Polícia de SP

\section{Falando em números}

\begin{tabular}{|c|c|c|r|}
\hline \multicolumn{4}{|c|}{ Suicídios cometidos por PMs } \\
\hline Ano & $N^{\circ}$ de Suicidios & Efetivo & $\begin{array}{l}\text { Suicidio } \\
/ 100,000\end{array}$ \\
\hline 1991 & 20 & 71145 & 28,11 \\
\hline 1992 & 23 & 70184 & 32,77 \\
\hline 1993 & 17 & 70347 & 24,17 \\
\hline 1994 & 28 & 72993 & 38,36 \\
\hline 1995 & 22 & 73247 & 30,04 \\
\hline 1996 & 27 & 77374 & 34,90 \\
\hline 1997 & 17 & 81892 & 20,76 \\
\hline 1998 & 33 & 81850 & 40,32 \\
\hline 1999 & 28 & 81677 & 34,28 \\
\hline 2000 & 23 & 83218 & 27,64 \\
\hline Total & 238 & 763927 & ${ }^{*} 31,15$ \\
\hline
\end{tabular}

média de todos os anos

As estatísticas nestas tabelas mostram um aspecto bastante delicado da Polícia Militar do Estado: o alto número de suicídios dentro da corporação. A quarta coluna mostra a média por 100 mil pessoas- coeficiente usado internacionalmente para medir o suicídio numa população. Para se ter uma idéia, segundo a Fundação Sistema Estadual de Análise de Dados (Seade), essa média na cidade de São Paulo é de 5/100 mil habitantes.

Obs: o total de efetivo não representa a realidade do número de PMs em serviço. A soma vale somente para o cálculo da média. 


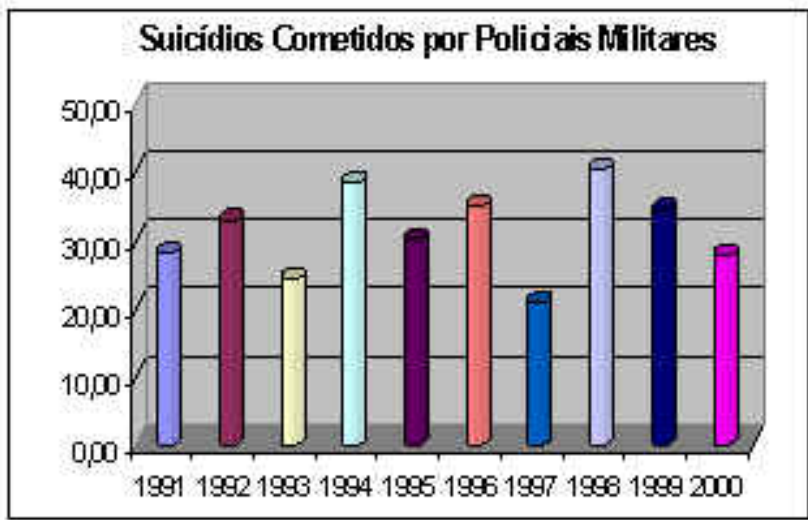

\section{Pra Você Saber}

Em outubro a Ouvidoria divulga os resultados da "Pesquisa sobre Uso da Força Letal por Policiais de SP" relativa à 2000. A pesquisa, que procura questionar o grande aumento de homicídios cometidos pela polícia, revelou, em 1999, dados impressionantes. Dos 365 civis envolvidos, 236 dos quais obtivemos laudo para a pesquisa foram mortos pela policia $(64,66 \%$ do total), enquanto que 9 dos 536 policiais envolvidos $(1,68 \%$ do total) morreram em confronto. Dos civis mortos, $28 \%$ não tinham relação com o delito em andamento, e $28 \%$ eram somente suspeitos. $56 \%$ não tinham nem mesmo antecedentes criminais.

\section{Digno de nota}

\section{Familia luta há oito anos para apurar morte de pai}

André Moreno Martins está desaparecido desde setembro 1993, em Salto de Pirapora, no interior paulista. Sua filha enterrou uma ossada, em 1995, localizada pela polícia, que pode ser de Martins, mas cuja perícia de identificação é protelada até hoje. Entre os ossos, o crânio tinha uma perfuração anormal - indicando provável vítima de homicídio.

A filha de Martins, Maria Fernanda Rodrigues Martins, enterrou o corpo por que reconheceu pertences que estariam junto a ele. Por isso, o IML local recusouse a examinar os ossos. O enterro foi feito, ainda que não tenha sido fornecido atestado de óbito até hoje - o que obriga

\section{Inquérito Policial: um longo caminho até o Tribunal}

Um levantamento realizado pela Ouvidoria em 144 casos de homicídios praticados, em 2000, por policiais civis e/ou militares na Capital, revelou que apenas 103 já chegaram ao conhecimento do Tribunal do Júri.

Dos 41 restantes, alguns jamais passarão pelo crivo das Varas do Júri: são casos que tramitaram em outros juízos, que apuraram apenas o crime praticado pelas vítimas dos homicídios.

Em todo caso de homicídio, diz a lei, deve ser instaurado um inquérito policial pela Polícia Civil (IP), independentemente do autor ser ou não policial. Quando o autor é policial 
Fernanda a continuar pagando contas do pai e, inclusive, seguro de vida. "No cemitério, o nome de meu pai ainda está anotado à lápis, a espera de confirmação", lamenta Fernanda.

As autoridades policiais e a Justiça Criminal têm pedido aos órgãos científicos competentes o exame de DNA para identificação do cadáver. Das duas universidades no interior paulista que poderiam realizá-lo, uma informou que não mais realizava o exame e a outra, recentemente, disse não poder aceitar mais um pedido de exame, devido ao alto número de requisições similares que chegavam ao local. "Até nos prontificamos em pagar pelos exames, mas sempre há uma desculpa", diz Fernanda, desgastada emocionalmente com a demora. Desde 1997 a Ouvidoria acompanha o caso, pressionando autoridades da polícia científica para que seja feito o exame de DNA e para que, ao menos, seja emitida a certidão de óbito. A falta de equipamentos e estrutura da polícia, no entanto, parece ser a maior dificuldade para que o processo chegue ao fim.

\begin{tabular}{|l|}
\hline OTITE CRÔNICA \\
E-mail: $\underline{\text { informa@ouvidoria-policia.sp.gov.br }}$ \\
Tel: 3823-5879 - Fax: 3823-5745 \\
Responsável: Igor Ribeiro \\
Colaboração: Giordano Mochel, Isabel Figueiredo, \\
Leonardo Muniz, Pedro Mathias
\end{tabular}

militar em serviço, ou que esteja de folga - mas usando uniforme ou arma da PM -, é instaurado, além do IP, outro inquérito pela Polícia Militar (IPM).

Entre os inquéritos cuja distribuição junto ao Judiciário a Ouvidoria tem conhecimento, poucos chegam ao conhecimento do Júri por meio dos IPs: dos 112 inquéritos instaurados pela Polícia Civil, apenas $42(37,5 \%)$ foram para o Júri. Por outro lado, dos 89 IPMs, só 1 não foi distribuído à Vara do Júri (ou seja, 98,87\% atingiram o devido destino).

O fato dos IPs não chegarem ao conhecimento do Júri nos preocupa, uma vez que há casos que são apurados apenas pela Polícia Civil e que correm risco de não serem analisados pelo Júri - juízo competente para apreciar crimes dolosos contra a vida.

Em 37 casos analisados pela Ouvidoria que foram apurados apenas em IPs, $13 \quad(35,13 \%)$ já foram apreciados em caráter definitivo pelo Judiciário, não havendo manifestação do Júri a respeito.

\section{Ouvidoria da Policia}

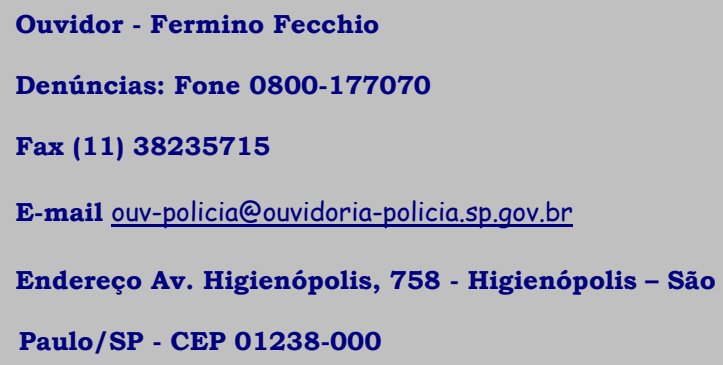




\section{Editorial}

\section{Falta Transparência. Ainda.}

\section{A semana passada foi marcada por uma série de graves denúncias}

versando sobre o trabalho do Grupo de Repressão e Análise dos Delitos de Intolerância (Gradi) da Polícia Militar.

Vários casos envolvendo ações do Gradi estão sendo acompanhados pela Ouvidoria - seis deles resultaram na morte de 29 pessoas, incluindo a ação na Rodovia Castelinho, em março.

Conforme publicado pela imprensa, os casos têm em comum práticas de legalidade questionáveis: a utilização de presos como informantes e sua infiltração em organizações criminosas. Presos foram retirados dos presídios e utilizados nas ações à revelia da legislação vigente. Presos alegam terem sido torturados e ameaçados pelos policiais.

Os policiais militares do Gradi exerceram funções investigativas, o que por si só já contraria a Constituição Federal, que determina ser a Polícia Civil competente para tanto. A falta de transparência e as dúvidas sobre a legalidade dos métodos utilizados pelos policiais militares do Gradi servem como alerta para que nos voltemos a uma questão mais ampla: o controle social da segurança pública. É importantíssimo que a população conheça sua polícia, suas ações e - mais do que isso - o resultado concreto de sua atuação, o que implica ter clareza, por exemplo, sobre o número de crimes solucionados. A já tão apontada necessidade de controle externo da atividade policial, que deveria ser realizado pelo Ministério Público e pelo Poder Judiciário, emerge novamente: em um Estado Democrático de Direito a polícia não pode ser um Estado à parte, com métodos, valores e regras próprias.

A atuação do Gradi continuará a ser acompanhada pela Ouvidoria, que preparou um dossiê a respeito dos casos que já acompanha e encaminhou cópia ao Procurador Geral de Justiça, ao Juiz Corregedor do Poder 
Judiciário e ao Ministro da Justiça.

Isabel Figueiredo

Assessora Jurídica da Ouvidoria da Polícia de SP

\section{Pesquisa mostra perfil dos policiais do Gradi}

A Ouvidoria pesquisou os antecedentes criminais de 22 policiais envolvidos em 4 ações suspeitas envolvendo policiais do Gradi e do $1^{\circ}$ Batalhão de Policiamento de Choque. Essas ações utilizaram direta ou indiretamente presos retirados dos presídios à revelia da legislação penal. Constatou-se que os 22 policiais pesquisados responderam no total à 162 inquéritos policiais militares por homicídio.

Já na época da criação do Gradi, em 1999, a imprensa noticiou a nomeação de um policial militar que havia participado do Massacre do Carandiru como um de seus coordenadores. Um dos policiais pesquisados respondeu a 32 inquéritos por homicídios entre 1988 e 2001, 22 deles arquivados na Justiça Militar. Outro policial também participou do Massacre do Carandiru e respondeu a 25 inquéritos por homicídio entre 1985 e 2001, 16 deles arquivados na Justiça Militar.

Embora a Ouvidoria, como o restante da sociedade, ainda não tenha obtido acesso à composição exata do Gradi da PM, os nomes já identificados mostram que se tratam de policiais rotineiramente utilizados em operações raramente esclarecidas à opinião pública.

\section{Presos eram transferidos com facilidade}

Um dos presos escalados para as operações do Gradi passou por 29 estabelecimentos prisionais do Estado de São Paulo durante os quatro anos em que esteve preso. Esse é um dos detalhes que chamaram a atenção desta Ouvidoria, que analisou a ficha de movimentação de alguns dos presos que foram usados pelo Gradi.

De acordo com sua ficha de movimentação, em muitos dos 29 presídios pelos quais passou, sua permanência foi de poucos dias, sendo transferido rapidamente. Parece estranho um preso ser transferido com essa freqüência, se uma das maiores reclamações do Judiciário é o não comparecimento dos presos requisitados para audiências muitas vezes a administração alega não poder transportá-los por terem sido transferidos de estabelecimento.

Outro detalhe que merece atenção é o fato de quatro presos terem passado pelo Centro de Observação Criminológica (COC) antes de terem sido requisitados pelo Gradi. A imprensa tem divulgado que um deles ficou por vários dias na PM. Oficialmente, neste periodo ele estava no $\mathrm{COC}$, onde permaneceu por mais de um ano.

\section{RESTA SABER}

- A retirada dos presos com destino ao Gradi e ao serviço reservado da PM era de conhecimento das autoridades superiores?

- Por que os presos eram transferidos ao COC antes de serem retirados pela Polícia?

- Que espécie de controle existe no COC em relação aos presos que eram retirados e aos que alegam terem sido ameaçados por policiais no estabelecimento?

- Onde estão os documentos referentes às supostas escutas telefônicas feitas pelos

policiais do Gradi e que, segundo a polícia, teriam dado origem à "Operação Castelinho"?

- O que autoriza o Gradi - órgão da PM e portanto com competência apenas ostensiva e preventiva - a realizar investigações, função constitucionalmente atribuída à Polícia Civil? 


\begin{tabular}{|c|}
\hline Otite CRÔNICA \\
Responsável: Igor Ribeiro \\
Colaboração: Isabel Figueiredo, \\
Leonardo Muniz, Kathleen Scholten. \\
E-mail: mailto:ouv-policia@ouvidoria- \\
policia.sp.gov.br \\
NOVO TELEFONE: (11) 3291-6033 \\
\hline
\end{tabular}

\begin{tabular}{|c||}
\hline Ouvidoria da Policia \\
Ouvidor - Fermino Fecchio \\
Denúncias por tel.: 0800-177070 \\
Novo FAx: (11) 3291-6027 \\
E-mail: ouv-policia@ouvidoria- \\
policia.sp.gov.br \\
Endereço: Rua Líbero Badaró, 600, $2^{\circ}$ \\
andar - Centro- São Paulo/SP - CEP \\
01008-000
\end{tabular}




\section{7- Bibliografia}

\section{Livros e artigos de periódicos:}

ABREU, C. Capítulos de História Colonial (1500-1800). São Paulo, Publifolha, 2000.

AFFONSO, B. S. A. O Controle Externo da Polícia: a Implementação da Lei Federal 9.229-96 no Estado de São Paulo. Dissertação de Mestrado defendida no Departamento de Ciência Política da Faculdade de Filosofia, Letras e Ciências Humanas da Universidade de São Paulo. São Paulo, mimeo, 2004.

ALEMIKA, E. E. O., CHUKWUMA I. C. (Org.). Civilian Oversight and Accountability of Police in Nigeria. Lagos, CLEEN\&PSC, 2003.

ARANTES, R. B. "Direito e Política: o Ministério Público e a defesa dos direitos coletivos". Revista Brasileira de Ciências Sociais, Vol. 14, n 39, fevereiro/99. São Paulo, Anpocs, 1999.

ARANTES, R. B. Ministério Público e Política no Brasil. São Paulo, Educ/Sumaré, 2002.

ARANTES, R. B., CUNHA, L. G. S. "Polícia Civil e Segurança Pública - Problemas de Funcionamento e Perspectivas de Reforma", in SADEK, M. T. (Org.) Delegados de Polícia. São Paulo, Sumaré, 2003.

ASSOCIAÇÃO BRASILEIRA DE OUVIDORES/OMBUDSMAN. Estatutos Sociais. João Pessoa, ABO, 16 de março de 1995. (Registrado no $6^{\circ}$ Cartório de Registro de Títulos, Documentos e Pessoas Jurídicas de São Paulo.)

BAlestreri, R. B. Direitos Humanos: Coisa de Polícia. Passo Fundo, Edições CAPEC, 2003.

BANDECCHI, B., ARROYO, L., ROSA, U. (Org.) Novo dicionário de História do Brasil. São Paulo, Melhoramentos, 1970.

BARCELOS, C. Rota 66-A história da polícia que mata. São Paulo, Globo, 1992.

BAYLEY, D. “A Foreign Policy for Democratic Policing”, in Policing and Society, n $5,1997$.

BAYLEY, D. Padrões de Policiamento: uma análise comparativa internacional. São Paulo, Edusp, 2001.

BENEVIDES, M. V. “A violência policial pode conviver com a democracia?”, in Lua Nova, v.1, nº4. São Paulo, Cedec, 1985.

BENEVIDES, M. V. "Conversando com os jovens sobre direitos humanos", in NOVAES, R., VANNUCHI, P. Juventude e Sociedade - Trabalho, educação, cultura e participação. São Paulo, Editora Fundação Perseu Abramo, 2004. 
BERG, J. Police Accountability in Southern African Commonwealth Countries. Cape Town, Institute of Criminology - University of Cape Town, 2005.

BICUDO, H. Meu depoimento sobre o esquadrão da morte. São Paulo, Martins Fontes, 2002.

BICUDO, H. O Direito e a Justiça no Brasil: uma análise crítica de cem anos. São Paulo, Símbolo, 1978.

BOBB, M. "Civilian Oversight of the Police in the United States". Los Angeles, Global Meeting on Civilian Oversight of Police, 2002.

BOBBIO, N. Direita e Esquerda: Razões e significados de uma distinção política. São Paulo, UNESP, 1995.

BOURGAULT, J., GOW, J. I. "Le difficile contrôle des activités et comportements de la police: le cas de la Sûreté du Québec" in Canadian Journal of Political Science / Revue Canadienne de Science Politique, 35:4, Décembre 2002, 747770 .

BRERETON, D. "Evaluating the Performance of External Oversight Bodies", in GOLDSMITH, A. J., LEWIS, C. Civilian Oversight of Policing: Governance, Democracy and Human Rights. Portland, Hart, 2000.

BRODEUR, J. “La grogne des policiers du Canadá”, in Hommes et Libertés, No 109 Policiers et citoyens, avril-mai 2000. Paris, Ligue des droits de l'homme, 2000.

CALDEIRA, T. P. R. Cidade de Muros - Crime, segregação e cidadania em São Paulo. São Paulo, Editora 34/Edusp, 2000.

CANO, I. Avaliando a Ouvidoria da Polícia de Minas Gerais: a Visão dos Denunciantes. http://www.ouvidoriadapolicia.mg.gov.br/pesquisas.htm, 2004.

CAVAlCANTI, R. B. "Problemas e Desafios da Polícia Civil - As Percepções dos Delegados", in SADEK, M. T. (Org.) Delegados de Polícia. São Paulo, Sumaré, 2003.

CESCA, C.G.G., CESCA, W. Estratégias empresariais diante do novo consumidor. São Paulo, Summus, 2000.

COMITÉ PERMANENT DE CONTRÔLE DES SERVICES DE POLICE. Brochure de présentation du Comité P. Bruxelles, Editions Politeia, 2003.

CONSTITUIÇÃO DA REPÚBLICA FEDERATIVA DO BRASIL. São Paulo, Saraiva, 1996 (13 $3^{\mathrm{a}}$ edição) e 2000 ( $24^{\mathrm{a}}$ edição).

DEBERT, G. G. "Ministério Público no Pará", in SADEK, M. T. (org.) Justiça e Cidadania no Brasil. São Paulo, Sumaré/Idesp, 2000.

DELAUNAY, B. Le Médiateur de la République. Paris, PUF, 1999. 
DIAS NETO, T. Policiamento Comunitário e Controle sobre a Polícia: a experiência norte-americana. São Paulo, IBCCRIM, 2000.

FAORO, R. Os Donos do Poder - Formação do patronato político brasileiro. São Paulo, Globo, 1996.

FERRAZ, A. A. M. C. Ministério Público: instituição e processo. São Paulo, Atlas, 1997.

FOLHA DE S.PAULO. "Estados criticam federalização de crimes contra direitos humanos." São Paulo, Folha de S. Paulo, 27 de janeiro de 2004.

FOLHA DE S.PAULO. "Folha inova e cria cargo de Ombudsman." São Paulo, Folha de S. Paulo, 23 de setembro de 1989.

FOLHA DE S.PAULO. "Ombudsman da Suécia recomenda paciência aos colegas brasileiros.” São Paulo, Folha de S. Paulo, 11 de agosto de 1987.

GIANGRANDE, V. “A comunicação na era do consumidor”. In KUNSCH, M.M.K. (Org.) Obtendo resultados com relações públicas. São Paulo, Pioneira Thomson Learning, 2002.

GIANGRANDE, V., FIGUEIREDO, J.C. O cliente tem mais do que razão - A importância do Ombudsman para a eficácia empresarial. São Paulo, Editora Gente, 1997.

GOLDSMITH, A. "Police Accountability Reform in Colombia: the Civilian Oversight", in GOLDSMITH, A. J., LEWIS, C. Civilian Oversight of Policing: Governance, Democracy and Human Rights. Portland, Hart, 2000.

GOMES, M. E. C. "Do Instituto do Ombudsman à Construção das Ouvidorias Públicas no Brasil" in LYRA, R.P. (Org.) A Ouvidoria na esfera pública brasileira. João Pessoa, Editora Universitária da UFPB, 2000.

GONÇALVES, L. M. D. Guia Prático de Funcionamento de uma Ouvidoria de Polícia. Brasília, Fórum Nacional de Ouvidores de Polícia, sem data.

GRAHAM, S. A. "Uma visão sobre a Police Complaints Authority" in LEMGRUBER, J., MUSUMECI, L., CANO, I. Quem vigia os vigias? Um estudo sobre controle externo da polícia no Brasil. Rio de Janeiro, Record, 2003.

GUERRERO-DALEY, T. "Supervisão Civil da Polícia: elementos-chave para um processo efetivo" in OUVIDORIA DA POLÍCIA DE MINAS GERAIS. $A$ Ouvidoria agora vai falar - Seleção de Textos e Relatório 2003 da Ouvidoria da Polícia de Minas Gerais. Belo Horizonte, Gráfica Editora Del Rey, 2004.

GUIMARÃES, R. R. C. Controle Externo da Atividade Policial pelo Ministério Público. Curitiba, Juruá, 2002. 
HERZOG, S. "Evaluating the Performance of External Oversight Bodies", in GOLDSMITH, A. J., LEWIS, C. Civilian Oversight of Policing: Governance, Democracy and Human Rights. Portland, Hart, 2000.

HOLANDA, S.B. (Org.). História Geral da Civilização Brasileira - Tomo I - A época colonial. São Paulo, Difusão Européia do Livro, 1960.

HOUAISS, A., VILlAR, M. Dicionário Houaiss da Língua Portuguesa. Rio de Janeiro, Objetiva, 2001.

INSTITUTO CIDADANIA. Projeto Segurança Pública para o Brasil. São Paulo, Instituto Cidadania, 2002.

KAHN, T. Velha e Nova Polícia - Polícia e Políticas de Segurança Pública no Brasil Atual. São Paulo, Sicurezza, 2002.

KANT de LIMA, R. A Polícia da cidade do Rio de Janeiro: seus dilemas e seus paradoxos. Rio de Janeiro, Forense, 1995.

KERCHE, F. "O Ministério Público Brasileiro e seus Mecanismos de Accountability". Trabalho apresentado no XXIII Encontro Anual da Anpocs, 1999B.

KERCHE, F. "O Ministério Público e a Constituinte de 1987/88”, in SADEK, M. T. (org.) O Sistema de Justiça. São Paulo, Sumaré/Idesp, 1999A.

LACERDA, A. V. As Ouvidorias do Brasil Colônia. Curitiba, Juruá, 2000.

LEITE, C. B. Ombudsman, corregedor administrativo: a instituição escandinava que o mundo vem adotando. Rio de Janeiro, Zahar, 1975.

LEMGRUBER, J., MUSUMECI, L., CANO, I. Quem vigia os vigias? Um estudo sobre controle externo da polícia no Brasil. Rio de Janeiro, Record, 2003.

LEWIS, C. "The Politics of Civilian Oversight: Serious Commitment or Lip Service?", in GOLDSMITH, A., LEWIS, C. (Org.) Civilian Oversight of Policing: Governance, Democracy and Human Rights. Oxford, Hart, 2000.

LEWIS, C., PRENZLER, T. "Civilian Oversight of Police in Australia", in Trends \& Issues in crime and criminal justice, $\mathrm{N}^{\mathrm{o}}$ 141. Canberra, Australian Institute of Criminology, december 1999.

MACAULAY, F. "Problems of police oversight in Brazil" (working paper). University of Oxford, Centre for Brazilian Studies, 2002.

MANBY, B. "The South African Independent Complaints Directorate", in GOLDSMITH, A. J., LEWIS, C. Civilian Oversight of Policing: Governance, Democracy and Human Rights. Portland, Hart, 2000.

MARIANO, B. D. "Dicotomia estrutural e violência policial" in Folha de S.Paulo, 24/09/1997. São Paulo, Folha de S.Paulo, 1997. 
MARIANO, B. D. "O exemplo da polícia canadense" in Folha de S.Paulo, 25/12/1998. São Paulo, Folha de S.Paulo, 1998.

MARIANO, B. D. "Propostas para mudar a polícia" in Folha de S.Paulo, 27/07/1999. São Paulo, Folha de S.Paulo, 1999.

MARIANO, B. D. Ouvidoria de Polícia: a constituição pública dos direitos humanos A primeira experiência de Ombudsman de Polícia no Brasil. São Paulo, Dissertação de mestrado em ciências sociais, PUC/SP, 2000.

MARIANO, B. D. "Autonomia e Independência como Condições do Controle Externo da Polícia" in MARIANO, B. D. (Org.). Conferência Internacional sobre Controle Externo da Polícia Brasil - Canadá. Osasco, JM Edições, $2000 \mathrm{~b}$.

MARIANO, B. D. Por um novo modelo de polícia no Brasil - A inclusão dos municípios no sistema de segurança pública. São Paulo, Editora Fundação Perseu Abramo, 2004.

MARIANO, B. D., REARDON, Pe. F., WEIS, C. Por uma Nova Política de Segurança e Cidadania. São Paulo, Condepe, 1994.

MARIANO, B. D. (Org.). Conferência Internacional sobre Controle Externo da Polícia Brasil - Canadá. Osasco, JM Edições, 2000.

MASUKU, T. Strengthening Democratic Policing in South Africa: Enhancing and Coordinating the Internal and External Accountability Systems of the South African Police Service. Johannesburg, Center for the Study of Violence and Reconciliation, 2005.

MAXIMIANO, A. R. "O controle externo da atividade policial - a IGAI" in LEMGRUBER, J., MUSUMECI, L., CANO, I. Quem vigia os vigias? Um estudo sobre controle externo da polícia no Brasil. Rio de Janeiro, Record, 2003.

McKENZIE, K. "Controle externo da polícia: a experiência sul-africana" in LEMGRUBER, J., MUSUMECI, L., CANO, I. Quem vigia os vigias? Um estudo sobre controle externo da polícia no Brasil. Rio de Janeiro, Record, 2003.

MENDEZ, J. E. "Problemas da violência ilegal: indrodução" in PINHEIRO, P. S. Democracia, Violência e Injustiça: o Não-Estado de direito na América Latina. São Paulo, Paz e Terra, 2000.

MESQUITA NETO, P., AFFONSO, B. S. A. Segundo Relatório Nacional sobre os Direitos Humanos no Brasil. São Paulo, Comissão Teotônio Vilela de Direitos Humanos, 2002.

MILLER, J. Civilian Oversight of Policing - Lessons from the Literature. Vera Institute of Justice, Global Meeting on Civilian Oversight of Police, Los Angeles, May 58, 2002. http://www.vera.org/publication pdf/178 338.pdf 
MINGARDI, G. Tiras, Gansos e Trutas - Cotidiano e Reforma na Polícia Civil. São Paulo, Scritta, 1992.

O TEMPO. “Abuso Policial” in O Tempo, 20/10/2005. Belo Horizonte, O Tempo, 2005.

O’DONNELL, G. “Accountability Horizontal e Novas Poliarquias” in Lua Nova, n 44. São Paulo, Cedec, 1998.

O'DONNELL, G. "Poliarquias e a (in)efetividade da lei na América Latina" in Novos Estudos, No 51, Julho 1998. São Paulo, Cebrap, 1998.

O'LOAN, N. The New Complaints System. Toronto, Cacole Annual Conference, June 2004.

O'RAWE, M, MOORE, L. "Accountability and Police Complaints in Northern Ireland: Leaving the Past Behind?", in GOLDSMITH, A. J., LEWIS, C. Civilian Oversight of Policing: Governance, Democracy and Human Rights. Portland, Hart, 2000.

PHILLIPS, E., TRONE, J. "Building Public Confidence in Police Through Civilian Oversight”. New York, Vera Institute of Justice, 2002.

PINHEIRO, I. "Ministério Público novo de guerra", in Observatório da Imprensa, n97, 5 de setembro de 2000.

PINHEIRO, P. S. Escritos Indignados - Polícia, Prisões e Política no Estado Autoritário. São Paulo, Brasiliense, 1984.

PINHEIRO, P. S. Democracia, Violência e Injustiça: o Não-Estado de direito na América Latina. São Paulo, Paz e Terra, 2000.

PINHEIRO, P. S., BRAUN, E. (Org.) Democracia X Violência - Reflexões para a Constituinte. Rio de Janeiro, Paz e Terra, 1986.

POLICE ASSESSMENT RESOURCE CENTER. Review of National Police Oversight Models for the Eugene Police Commission. Los Angeles, PARC, 2005.

PROGRAMA NACIONAL DE DIREITOS HUMANOS. Brasília, Presidência da República, Secretaria de Comunicação Social, Ministério da Justiça, 1996.

RAMOS, S., MUSUMECI, L. Elemento Suspeito: abordagem policial e discriminação na cidade do Rio de Janeiro. Rio de Janeiro, Civilização Brasileira, 2005.

REZENDE, J. R. G. "Não há direitos humanos sem emprego, pão e escola", in Revista do Legislativo. Belo Horizonte, Assembléia Legislativa do Estado de Minas Gerais, jul-set/1998.

ROTHE, R. M. "Ombudsman de Polícia: Relação com a Sociedade e com as Polícias", in MARIANO, B. D. (Org.) $1^{a}$ Conferência Internacional Sobre Controle Externo da Polícia Brasil-Canadá. Osasco, JM Edições, 2000. 
ROTHE, M. R. "O Papel do Ouvidor no Sistema de Segurança Pública". Texto apresentado no VI Encontro Nacional de Ouvidores/Ombudsman, realizado em Recife, de 19 a 21 de setembro de 2001.

ROTHE, M. R. "O Papel da Ouvidoria na Atividade Policial", in OUVIDORIA DA POLÍCIA DE MINAS GERAIS. A Ouvidoria agora vai falar - Seleção de Textos e Relatório 2003 da Ouvidoria da Polícia de Minas Gerais. Belo Horizonte, Gráfica Editora Del Rey, 2004.

SADEK, M. T. (org.) O Ministério Público e a Justiça no Brasil. São Paulo, Sumaré/Idesp, 1997.

SADEK, M. T. (org.) Delegados de Polícia. São Paulo, Sumaré, 2003.

SADEK. M. T. "Cidadania e Ministério Público", in SADEK, M. T. (org.) Justiça e Cidadania no Brasil. São Paulo, Sumaré/Idesp, 2000.

SALVADOR, F. V. História do Brasil 1500-1627. São Paulo, Melhoramentos, 1965.

SANCHES FILHO, A. O. "Ministério Público e controle externo da polícia na Bahia", in SADEK, M. T. (Org.) Justiça e Cidadania no Brasil. São Paulo, Sumaré/Idesp, 2000.

SILVA, C. A. "Promotores de Justiça e novas formas de atuação em defesa de interesses sociais e coletivos". Revista Brasileira de Ciências Sociais, Vol. 16, $\mathrm{n}^{\circ}$ 45, fevereiro 2001. São Paulo, Anpocs, 2001.

SKOLNICK, J. H., FYFE, J.J. Above the Law-Police and the Excessive Use of Force. New York, The Free Press, 1993.

SOARES, L. E. Meu Casaco de General - Quinhentos dias no front da segurança pública no Rio de Janeiro. São Paulo, Companhia das Letras, 2000.

STONE, C. "A importância do controle externo da polícia nas sociedades democráticas: uma perspectiva internacional" in LEMGRUBER, J., MUSUMECI, L., CANO, I. Quem vigia os vigias? Um estudo sobre controle externo da polícia no Brasil. Rio de Janeiro, Record, 2003.

TONETO, B. "A Ouvidoria de Polícia de São Paulo e o fórum nacional dos ouvidores de polícia" in LYRA, R.P. (Org.) A Ouvidoria na esfera pública brasileira. João Pessoa, Editora Universitária da UFPB, 2000.

VAINFAS, R. (Org.) Dicionário do Brasil Colonial (1500-1808). Rio de Janeiro, Objetiva, 2000.

VIANNA, H. História do Brasil. São Paulo, Melhoramentos, 1966.

VIANNA, L. W., e BURGOS, M. "Revolução Processual do Direito e Democracia Progressiva", in VIANNA, L. W. (Org.) A Democracia e os Três Poderes no Brasil. Belo Horizonte, UFMG, 2002. 
VOLPI, A. Na trilha da excelência - Vida de Vera Giangrande. São Paulo, Negócio Editora, 2002.

WALKER, S. Police Accountability: the role of citizen oversight. Belmont, Wadsworth, 2001.

WeHling, A., WeHLING, M. J. C. Formação do Brasil Colonial. Rio de Janeiro, Nova Fronteira, 1994.

Publicações e relatórios produzidos pelas ouvidorias:

\section{Bahia:}

OUVIDORIA DA SECRETARIA DA SEGURANÇA PÚBLICA. Relatório de Atividades - 2004. Salvador, mimeo, janeiro 2005.

\section{Ceará:}

DIRETORIA DA DEFESA SOCIAL E OUVIDORIA GERAL DA SPDS. Relatório de Atividades - Período: Jan a dez/2004. Fortaleza, mimeo, 2005.

\section{Goiás:}

OUVIDORIA GERAL DE POLÍCIA. Relatório Anual da Ouvidoria Geral de Polícia de Goiás de 2004. Goiânia, Ofício Circular nº 002/2005, 13 de janeiro de 2005.

\section{Mato Grosso:}

OUVIDORIA DE POLÍCIA DE MATO GROSSO. Relatório de Atividades (Agosto de 2003 - Agosto de 2004). Cuiabá, mimeo, setembro de 2004.

\section{Minas Gerais:}

CENTRO DE ESTUDOS DE CRIMINALIDADE E SEGURANÇA PÚBLICA DA UFMG (CRISP) E OUVIDORIA DA POLÍCIA DO ESTADO DE MINAS GERAIS. Relatório de Pesquisa - O papel da ouvidoria de polícia de Minas Gerais no controle externo da atividade policial. Belo Horizonte, mimeo, setembro de 2004.

OUVIDORIA DA POLÍCIA DE MINAS GERAIS. A Ouvidoria agora vai falar Seleção de Textos e Relatório 2003 da Ouvidoria da Polícia de Minas Gerais. Belo Horizonte, Gráfica Editora Del Rey, 2004.

OUVIDORIA DA POLÍCIA DE MINAS GERAIS. A Ouvidoria de Polícia de Minas Gerais mostra o que faz. Belo Horizonte, Artes Gráficas Formato, 2004. 
OUVIDORIA DA POLÍCIA DE MINAS GERAIS. Relatório Trimestral de Prestação de Contas - Janeiro a Março de 2003. Belo Horizonte, mimeo, 2003.

OUVIDORIA DA POLÍCIA DE MINAS GERAIS. Relatório Trimestral de Prestação de Contas - Abril a Junho de 2003. Belo Horizonte, mimeo, 2003.

OUVIDORIA DA POLÍCIA DE MINAS GERAIS. Relatório Trimestral de Prestação de Contas - Julho a Setembro de 2003. Belo Horizonte, mimeo, 2003.

OUVIDORIA DA POLÍCIA DE MINAS GERAIS. Relatório Trimestral de Prestação de Contas - Outubro a Dezembro de 2003. Belo Horizonte, mimeo, 2004.

OUVIDORIA DA POLÍCIA DE MINAS GERAIS. Relatório Trimestral de Prestação de Contas - Janeiro a Março de 2004. Belo Horizonte, Acadepol, janeiro a março 2004.

OUVIDORIA DA POLÍCIA DE MINAS GERAIS. Relatório Trimestral de Prestação de Contas - Abril a Junho de 2004. Belo Horizonte, Acadepol, abril a junho 2004.

OUVIDORIA DA POLÍCIA DE MINAS GERAIS. Relatório Trimestral de Prestação de Contas - Julho a Setembro de 2004. Belo Horizonte, Acadepol, julho a setembro 2004.

OUVIDORIA DA POLÍCIA DE MINAS GERAIS. Relatório Trimestral de Prestação de Contas - Outubro a Dezembro de 2004. Belo Horizonte, Parque Gráfico da PMMG DAL/CAMB e Int., outubro a dezembro 2004.

OUVIDORIA DA POLÍCIA DE MINAS GERAIS. Relatório Trimestral de Prestação de Contas - Janeiro a Março de 2005. Belo Horizonte, Parque Gráfico da PMMG DAL/CAMB e Int., janeiro a março 2005.

OUVIDORIA DA POLÍCIA DE MINAS GERAIS. Relatório Trimestral de Prestação de Contas - Abril a Junho de 2005. Belo Horizonte, Parque Gráfico da PMMG DAL/CAMB e Int., abril a junho 2005.

\section{Pará:}

OUVIDORIA DO SISTEMA DE SEGURANÇA PÚBLICA DO ESTADO DO PARÁ. Relatório - Ano 2001. Belém, mimeo, dezembro 2002.

OUVIDORIA DO SISTEMA DE SEGURANÇA PÚBLICA DO ESTADO DO PARÁ. Relatório - Ano 2002. Belém, mimeo, setembro 2003.

OUVIDORIA DO SISTEMA DE SEGURANÇA PÚBLICA DO ESTADO DO PARÁ. Relatório - Ano 2003. Belém, mimeo, dezembro 2004.

\section{Paraná:}


OUVIDORIA DA POLÍCIA DO ESTADO. Relatório Anual - Janeiro a Dezembro / 2004. Curitiba, mimeo, 2005.

OUVIDORIA DA POLÍCIA DO ESTADO. Relatório Semestral - Julho a Dezembro / 2004. Curitiba, mimeo, 2005.

\section{Rio de Janeiro:}

OUVIDORIA DA POLÍCIA DO ESTADO DO RIO DE JANEIRO. Sumário das Atividades - 1 de janeiro de 2004 a 31 de março de 2004. Rio de Janeiro, mimeo, 2004.

OUVIDORIA DA POLÍCIA DO ESTADO DO RIO DE JANEIRO. Sumário das Atividades - 1 de abril de 2004 a 30 de junho de 2004. Rio de Janeiro, mimeo, 2004.

OUVIDORIA DA POLÍCIA DO ESTADO DO RIO DE JANEIRO. Sumário das Atividades -1 de julho de 2004 a 30 de setembro de 2004. Rio de Janeiro, mimeo, 2004.

OUVIDORIA DA POLÍCIA DO ESTADO DO RIO DE JANEIRO. Sumário das Atividades - 1 de outubroo de 2004 a 31 de dezembro de 2004. Rio de Janeiro, mimeo, 2005.

OUVIDORIA DA POLÍCIA DO ESTADO DO RIO DE JANEIRO. Sumário das Atividades -1 de janeiro de 2005 a 31 de março de 2005. Rio de Janeiro, mimeo, 2005.

OUVIDORIA DA POLÍCIA DO ESTADO DO RIO DE JANEIRO. Sumário das Atividades - 1 de abril de 2005 a 30 de junho de 2005. Rio de Janeiro, mimeo, 2005.

OUVIDORIA DA POLÍCIA DO ESTADO DO RIO DE JANEIRO. Sumário das Atividades -1 de julho de 2005 a 30 de setembro de 2005. Rio de Janeiro, mimeo, 2005.

\section{Rio Grande do Norte:}

OUVIDORIA DA DEFESA SOCIAL. Relatório - ano de 2001. Natal, mimeo, 2002.

OUVIDORIA DA DEFESA SOCIAL. Relatório - ano de 2002. Natal, mimeo, 2003.

OUVIDORIA DA DEFESA SOCIAL. Relatório - ano de 2003. Natal, mimeo, 2004.

OUVIDORIA DA DEFESA SOCIAL. Relatório - ano de 2004. Natal, mimeo, 2005.

\section{Rio Grande do Sul:}

OUVIDORIA DA JUSTIÇA E DA SEGURANÇA. Relatório de Atividades 1999-2001. Porto Alegre, Estado do Rio Grande do Sul, 2002. 
OUVIDORIA DA JUSTIÇA E DA SEGURANÇA. Relatório de Atividades 2004. Porto Alegre, mimeo, 2005.

\section{São Paulo:}

FÓRUM NACIONAL DE OUVIDORES DE POLÍCIA. Guia Prático de funcionamento de uma Ouvidoria de Polícia. São Paulo, Imprensa Oficial, 2000.

OUVIDORIA DA POLÍCIA DO ESTADO DE SÃO PAULO. Otite Crônica. Exemplares $\mathrm{n}^{\mathrm{o}} 1$ a 36 . Boletins eletrônicos publicados na internet.

OUVIDORIA DA POLÍCIA DO ESTADO DE SÃO PAULO. Relatório Anual de Prestação de Contas - 1996. São Paulo, Imprensa Oficial, 1997.

OUVIDORIA DA POLÍCIA DO ESTADO DE SÃO PAULO. Relatório Anual de Prestação de Contas - 1997. São Paulo, Imprensa Oficial, 1998.

OUVIDORIA DA POLÍCIA DO ESTADO DE SÃO PAULO. Relatório Anual de Prestação de Contas - 1998. São Paulo, Imprensa Oficial, 1999.

OUVIDORIA DA POLÍCIA DO ESTADO DE SÃO PAULO. Relatório Anual de Prestação de Contas - 1999. São Paulo, Imprensa Oficial, 2000.

OUVIDORIA DA POLÍCIA DO ESTADO DE SÃO PAULO. Relatório Anual de Prestação de Contas - 2000. São Paulo, Imprensa Oficial, 2001.

OUVIDORIA DA POLÍCIA DO ESTADO DE SÃO PAULO. Relatório Anual de Prestação de Contas - 2001. São Paulo, Imprensa Oficial, 2002.

OUVIDORIA DA POLÍCIA DO ESTADO DE SÃO PAULO. Relatório Anual de Prestação de Contas - 2002. São Paulo, mimeo, 2003.

OUVIDORIA DA POLÍCIA DO ESTADO DE SÃO PAULO. Relatório Anual de Prestação de Contas - 2003. São Paulo, mimeo, 2004.

OUVIDORIA DA POLÍCIA DO ESTADO DE SÃO PAULO. Relatório Anual de Prestação de Contas - 2004. São Paulo, mimeo, 2005.

OUVIDORIA DA POLÍCIA DO ESTADO DE SÃO PAULO. Relatório Semestral de Prestação de Contas - Janeiro a Junho de 2002. São Paulo, mimeo, 2002.

OUVIDORIA DA POLÍCIA DO ESTADO DE SÃO PAULO. Relatório Semestral de Prestação de Contas - $1^{\circ}$ Semestre de 2005. São Paulo, mimeo, 2005.

OUVIDORIA DA POLÍCIA DO ESTADO DE SÃO PAULO. Relatório Trimestral de Prestação de Contas - Janeiro a Março de 2002. São Paulo, mimeo, 2002.

OUVIDORIA DA POLÍCIA DO ESTADO DE SÃO PAULO. Relatório Trimestral de Prestação de Contas - Abril a Junho de 2002. São Paulo, mimeo, 2002. 
OUVIDORIA DA POLÍCIA DO ESTADO DE SÃO PAULO. Relatório Trimestral de Prestação de Contas - Julho a Setembro de 2002. São Paulo, mimeo, 2002.

OUVIDORIA DA POLÍCIA DO ESTADO DE SÃO PAULO. Relatório Trimestral de Prestação de Contas - Janeiro a Março de 2003. São Paulo, mimeo, 2003.

OUVIDORIA DA POLÍCIA DO ESTADO DE SÃO PAULO. Relatório Trimestral de Prestação de Contas - Abril a Junho de 2003. São Paulo, mimeo, 2003.

OUVIDORIA DA POLÍCIA DO ESTADO DE SÃO PAULO. Relatório Trimestral de Prestação de Contas - Julho a Setembro de 2003. São Paulo, mimeo, 2003.

OUVIDORIA DA POLÍCIA DO ESTADO DE SÃO PAULO. Relatório Trimestral de Prestação de Contas - Janeiro a Março de 2004. São Paulo, mimeo, 2004.

OUVIDORIA DA POLÍCIA DO ESTADO DE SÃO PAULO. Relatório Trimestral de Prestação de Contas - Abril a Junho de 2004. São Paulo, mimeo, 2004.

OUVIDORIA DA POLÍCIA DO ESTADO DE SÃO PAULO. Resistência Seguida de Morte: a apuração dos limites do uso da força letal no âmbito da Polícia Judiciária, do Ministério Público e do Poder Judiciário - uma abordagem processual. São Paulo, Imprensa Oficial, 2002.

Publicações e relatórios produzidos por outras instâncias de governo:

COMISSÃO DE CIDADANIA E DIREITOS HUMANOS DA ASSEMBLÉIA LEGISLATIVA DO ESTADO DO RIO GRANDE DO SUL (CCDH). Relatório Azul 1994. Porto Alegre, AL/RS, 1995.

COMISSÃO DE CIDADANIA E DIREITOS HUMANOS DA ASSEMBLÉIA LEGISLATIVA DO ESTADO DO RIO GRANDE DO SUL (CCDH). Relatório Azul 1995. Porto Alegre, AL/RS, 1996.

COMISSÃO DE CIDADANIA E DIREITOS HUMANOS DA ASSEMBLÉIA LEGISLATIVA DO ESTADO DO RIO GRANDE DO SUL (CCDH). Relatório Azul 1996. Porto Alegre, AL/RS, 1997.

COMISSÃO DE CIDADANIA E DIREITOS HUMANOS DA ASSEMBLÉIA LEGISLATIVA DO ESTADO DO RIO GRANDE DO SUL (CCDH). Relatório Azul 1997. Porto Alegre, AL/RS, 1998.

COMISSÃO DE CIDADANIA E DIREITOS HUMANOS DA ASSEMBLÉIA LEGISLATIVA DO ESTADO DO RIO GRANDE DO SUL (CCDH). Relatório Azul 1998/1999. Porto Alegre, AL/RS, 1999.

COMISSÃO DE CIDADANIA E DIREITOS HUMANOS DA ASSEMBLÉIA LEGISLATIVA DO ESTADO DO RIO GRANDE DO SUL (CCDH). Relatório Azul 1999/2000. Porto Alegre, AL/RS, 2000. 
COMISSÃO DE CIDADANIA E DIREITOS HUMANOS DA ASSEMBLÉIA LEGISLATIVA DO ESTADO DO RIO GRANDE DO SUL (CCDH). Relatório Azul 2000/2001. Porto Alegre, AL/RS, 2001.

COMISSÃO DE CIDADANIA E DIREITOS HUMANOS DA ASSEMBLÉIA LEGISLATIVA DO ESTADO DO RIO GRANDE DO SUL (CCDH). Relatório Azul 2003. Porto Alegre, AL/RS, 2004.

FÓRUM NACIONAL DE OUVIDORES DA POLÍCIA. Ata da III Reunião do Fórum Nacional de Ouvidores. Brasília, mimeo, 21 de maio de 2003.

FÓRUM NACIONAL DE OUVIDORES DA POLÍCIA. Ata da IV Reunião do Fórum Nacional de Ouvidores. Brasília, mimeo, $1^{\circ}$ e 2 de outubro de 2003.

FÓRUM NACIONAL DE OUVIDORES DA POLÍCIA. Ata da $V^{a}$ Reunião do Fórum Nacional de Ouvidores. Belo Horizonte, mimeo, 27 de junho de 2004. 